Cochrane Database of Systematic Reviews

\title{
Placebo response and remission rates in randomised trials of induction and maintenance therapy for ulcerative colitis (Review)
}

Jairath V, Zou GY, Parker CE, MacDonald JK, AlAmeel T, Al Beshir M, Almadi MA, Al-Taweel T, Atkinson NSS, Biswas S, Chapman T, Dulai PS, Glaire MA, Hoekman DR, Koutsoumpas A, Minas E, Mosli MH, Samaan M, Khanna R, Travis S, D’Haens G, Sandborn WJ, Feagan BG

\footnotetext{
Jairath V, Zou GY, Parker CE, MacDonald JK, AlAmeel T, Al Beshir M, Almadi MA, Al-Taweel T, Atkinson NSS, Biswas S, Chapman T, Dulai PS, Glaire MA, Hoekman DR, Koutsoumpas A, Minas E, Mosli MH, Samaan M, Khanna R, Travis S, D’Haens G, Sandborn WJ, Feagan BG. Placebo response and remission rates in randomised trials of induction and maintenance therapy for ulcerative colitis. Cochrane Database of Systematic Reviews 2017, Issue 9. Art. No.: CD011572.

DOI: 10.1002/14651858.CD011572.pub2.
}

www.cochranelibrary.com 


\section{TABLE OF CONTENTS}

HEADER

ABSTRACT

PLAIN LANGUAGE SUMMARY

BACKGROUND

OBJECTIVES

METHODS

RESULTS

Figure 1.

Figure 2.

Figure 3.

Figure 4.

Figure 5.

Figure 6.

Figure 7.

Figure 8.

Figure 9.

Figure 10.

DISCUSSION

AUTHORS' CONCLUSIONS

ACKNOWLEDGEMENTS

REFERENCES

CHARACTERISTICS OF STUDIES

DATA AND ANALYSES

ADDITIONAL TABLES .

APPENDICES

CONTRIBUTIONS OF AUTHORS

DECLARATIONS OF INTEREST

INDEX TERMS . . . . . . . . . . . . . . . . . . . . . . . . . . . . . . . . . . . . 138 
[Intervention Review]

\title{
Placebo response and remission rates in randomised trials of induction and maintenance therapy for ulcerative colitis
}

\author{
Vipul Jairath ${ }^{1,2,3}$, GY Zou ${ }^{2,3}$, Claire E Parker ${ }^{2}$, John K MacDonald ${ }^{1,4}$, Turki AlAmeel ${ }^{5}$, Mohammad Al Beshir ${ }^{5}$, Majid A Almadi \\ 6,7, Talal Al-Taweel ${ }^{8}$, Nathan SS Atkinson ${ }^{9}$, Sujata Biswas ${ }^{10}$, Thomas Chapman ${ }^{11}$, Parambir S Dulai ${ }^{12}$, Mark A Glaire ${ }^{13}$, Daniël R \\ Hoekman $^{14}$, Andreas Koutsoumpas ${ }^{9}$, Elizabeth Minas ${ }^{15}$, Mahmoud H Mosli ${ }^{16}$, Mark Samaan ${ }^{14}$, Reena Khanna ${ }^{1,2}$, Simon Travis ${ }^{17}$, \\ Geert D’Haens $^{14,18}$, William J Sandborn ${ }^{19,20}$, Brian G Feagan ${ }^{1,2,3,4}$ \\ ${ }^{1}$ Department of Medicine, University of Western Ontario, London, Canada. ${ }^{2}$ Robarts Clinical Trials, London, Canada. ${ }^{3}$ Department \\ of Epidemiology and Biostatistics, University of Western Ontario, London, Canada. ${ }^{4}$ Cochrane IBD Group, Robarts Clinical Trials, \\ London, Canada. ${ }^{5}$ Department of Medicine, King Fahad Specialist Hospital-Dammam, Dammam, Saudi Arabia. ${ }^{6}$ Division of Gas- \\ troenterology, King Khalid University Hospital, Riyadh, Saudi Arabia. ${ }^{7}$ King Saud University, Riyadh, Saudi Arabia. ${ }^{8}$ Mubarak Al- \\ Kabeer Hospital, Jabriyah, Kuwait. ${ }^{9}$ Gastroenterology Unit, John Radcliffe Hospital, Oxford, UK. ${ }^{10}$ Translational Gastroenterology \\ Unit, Wellcome Trust Centre for Human Genetics, Oxford, UK. ${ }^{11}$ Translational Gastroenterology Unit, John Radcliffe Hospital, \\ Oxford, UK. ${ }^{12}$ University of California San Diego, La Jolla, CA, USA. ${ }^{13}$ John Radcliffe Hospital, Oxford, UK. ${ }^{14}$ Academic Medical \\ Center, Amsterdam, Netherlands. ${ }^{15}$ Wexham Park Hospital, Slough, UK. ${ }^{16}$ King Abdulaziz University Hospital, King Abdulaziz Uni- \\ versity, Jeddah, Saudi Arabia. ${ }^{17}$ Translational Gastroenterology Unit, Nuffield Department of Medicine, University of Oxford, Oxford, \\ UK. ${ }^{18}$ Robarts Clinical Trials, Amsterdam, Netherlands. ${ }^{19}$ Division of Gastroenterology, University of California San Diego, La Jolla, \\ CA, USA. ${ }^{20}$ Robarts Clinical Trials, San Diego, CA, USA
}

Contact address: Vipul Jairath, Department of Medicine, University of Western Ontario, London, ON, Canada. vipul.jairath@robartsinc.com.

Editorial group: Cochrane IBD Group.

Publication status and date: New, published in Issue 9, 2017.

Citation: Jairath V, Zou GY, Parker CE, MacDonald JK, AlAmeel T, Al Beshir M, Almadi MA, Al-Taweel T, Atkinson NSS, Biswas S, Chapman T, Dulai PS, Glaire MA, Hoekman DR, Koutsoumpas A, Minas E, Mosli MH, Samaan M, Khanna R, Travis S, D’Haens G, Sandborn WJ, Feagan BG. Placebo response and remission rates in randomised trials of induction and maintenance therapy for ulcerative colitis. Cochrane Database of Systematic Reviews 2017, Issue 9. Art. No.: CD011572. DOI: 10.1002/14651858.CD011572.pub2.

Copyright (C) 2017 The Cochrane Collaboration. Published by John Wiley \& Sons, Ltd.

\section{A B S T R A C T}

\section{Background}

It is important to minimize placebo rates in randomised controlled trials (RCTs) to efficiently detect treatment differences between interventions. Historically, high placebo rates have been observed in clinical trials of ulcerative colitis (UC). A better understanding of factors influencing placebo rates may lead to more informed clinical trial design.

\section{Objectives}

A systematic review and meta-analysis was conducted to evaluate placebo response and remission rates in RCTs evaluating UC treatments in adult patients.

\section{Search methods}

Electronic databases (i.e. MEDLINE, EMBASE, and CENTRAL) were searched from inception to 1 March 2017 with no language restrictions applied. Reference lists and conference proceedings of major gastroenterology meetings were also handsearched to identify additional studies.

Placebo response and remission rates in randomised trials of induction and maintenance therapy for ulcerative colitis (Review)

Copyright () 2017 The Cochrane Collaboration. Published by John Wiley \& Sons, Ltd. 


\section{Selection criteria}

Placebo-controlled RCTs of adult patients with UC treated with corticosteroids, aminosalicylates, immunosuppressives or biologics were eligible, provided enrolment and outcome assessment was conducted using the Ulcerative Colitis Disease Activity Index (UCDAI) or the Mayo Clinic Score. The minimum trial duration was two weeks for induction trials and four months maintenance trials.

\section{Data collection and analysis}

Pairs of authors independently determined study eligibility and extracted data with any disagreements resolved through consensus. Outcomes of interest included the proportion of patients with clinical response and remission. Trial characteristics such as the design, participant demographics and disease history, interventions, and enrolment and assessment criteria were also recorded. The methodological quality of the included studies was evaluated using the Cochrane risk of bias tool. Pooled placebo response and remission rates and $95 \%$ confidence intervals $(95 \% \mathrm{CI})$ were calculated using a binomial normal model for proportions. Induction of remission and maintenance studies were pooled separately. The impact of study-level characteristics on placebo response and remission rates was investigated using mixed-effects meta-regression analyses with logits of event rates as the outcome variables. An assessment of pooled placebo rates over time was conducted using a cumulative meta-analysis based on date of publication. Publication bias was examined using funnel plots.

\section{Main results}

The screening process identified 61 included studies which encompass 58 induction phases (5111 patients randomised to placebo) and 12 maintenance phases (1579 patients randomised to placebo). For induction trials, the pooled estimate of placebo response was $33 \%$ (95\% CI 30\% to 36\%) while the pooled estimate of placebo remission was $12 \%$ (95\% CI 9\% to 15\%). For maintenance trials, the pooled estimate of placebo response was $23 \%$ (95\% CI $19 \%$ to $28 \%$ ) while the pooled estimate of placebo remission was $17 \%$ ( $95 \%$ CI $10 \%$ to $27 \%)$.

Studies enrolling patients with more active disease confirmed objectively by endoscopy were associated with significantly lower placebo remission and response rates than trials enrolling patients with less active disease (27\% versus 4\%, OR 2.60, $95 \%$ CI 1.25 to 5.42 , $\mathrm{P}=0.01$ for $\mathrm{UCDAI}$ endoscopy sub score $\geq 1$ versus $\geq 2$ for remission; and $27 \%$ versus $4 \%$, OR $1.70,95 \%$ CI 1.02 to 2.82 , $\mathrm{P}=$ 0.02 for UCDAI endoscopy sub score greater than or equal to one versus greater than or equal to two for response). With respect to drug class, the lowest placebo response and remission rates were observed in trials evaluating corticosteroids (23\%; $95 \%$ CI 19 to $29 \%$, and 5\%; $95 \%$ CI 2 to $11 \%$, respectively). Trials of biologics had the highest placebo response rate (35\%; $95 \%$ CI 30 to $41 \%$ ), while trials evaluating aminosalicylates had the highest placebo remission rate (18\%; 95\% CI 12 to $24 \%)$. Disease duration of greater than five years prior to enrolment was associated with a significantly lower placebo response rate compared to disease duration of less than or equal to five years ( $29 \%$ versus $47 \%$, respectively; OR $0.54,95 \%$ CI 0.32 to $0.92, \mathrm{P}=0.02)$. The requirement of a minimum rectal bleeding score for study eligibility was associated with an increased placebo response rate compared to studies that did not use rectal bleeding for trial eligibility (37\% versus 32\%, respectively; OR 1.70, 95\% CI 1.02 to 2.82, P = 0.02). Finally, the time point of primary outcome assessment was found to be significantly associated with placebo remission rates such that every one week increment in endpoint assessment was associated with a $6 \%$ increase in the placebo remission rate (OR 1.06, 95\% CI 1.02 to $1.10, \mathrm{P}=0.01$ ).

Cumulative meta-analysis indicated a consistent increase in the placebo response rate from 1987 to 2007 (from 13\% to 33\%), although rates have remained constant from 2008 to 2015 (32\% to 34\%). Similarly, placebo remission rates increased from 1987 to 2007 ( $5 \%$ to $14 \%$ ) but have remained constant from 2008 to 2015 (12 to 14\%). On meta-regression, there were no statistically significant differences between the 1987-2007 and 2008-2015 point estimates for both response $(\mathrm{P}=0.81)$ and remission $(\mathrm{P}=0.32)$.

\section{Authors' conclusions}

Placebo response and remission rates vary according to endoscopic disease severity and rectal bleeding score at trial entry, class of agent, disease duration, and the time point at which the primary outcome was measured. These observations have important implications for the design and conduct of future clinical trials in UC and will help researchers design trials, determine required sample sizes and also provide useful information about trial design features which should be considered when planning new trials.

\section{PLAIN LANGUAGE SUMMARY}

Placebo response and remission rates in randomised trials of induction and maintenance therapy for ulcerative colitis What is ulcerative colitis?

Placebo response and remission rates in randomised trials of induction and maintenance therapy for ulcerative colitis (Review) 
Ulcerative colitis (UC) is a recurrent, chronic inflammatory bowel disease that usually affects the large intestine (colon). Symptoms include abdominal pain, urgency to pass stools, bloody diarrhoea, weight loss and fatigue. When symptoms stop patients are considered to be in remission. Clinical trials for UC are usually designed to assess whether a drug treatment brings about a clinical response (an improvement of disease symptoms) or remission (typically measured within eight weeks of treatment) or helps to maintain a clinical response or remission over a longer period of time (typically measured after one year of treatment).

\section{What is the placebo effect?}

The placebo effect occurs when a patient experiences an actual or perceived improvement in health after receiving a dummy (non-active) treatment. The factors influencing this are not completely understood but may be due to the psychological effect of receiving treatment, rather than the treatment itself. Understanding the size of the placebo effect and the factors that influence it is important, because the placebo response rate is used to calculate the number of patients needed when designing a clinical trial of new drug treatment. Ideally when designing a clinical trial researchers aim to minimize the size of the placebo effect to best detect the true difference between the active drug and dummy treatment with the minimum number of patients. This means that clinical trials, which are costly to conduct, could be designed with fewer numbers of patients, greater efficiency, lower cost and ultimately bring new drugs to patients more quickly.

\section{What did the researchers investigate?}

The researchers reviewed published randomised placebo-controlled trials in UC of several classes of drugs to quantify what the placebo response rates were overall, and how these response rates have evolved over time. They also investigated how factors related to the study design, participants, treatments or outcomes influenced the placebo rates in UC trials. The medical literature was searched and analysed up to 1 March 2017.

\section{What did the researchers find?}

Sixty-one trials were included which evaluated 58 induction phases (5111 patients randomised to placebo) and 12 maintenance phases (1579 patients randomised to placebo). The researchers found that placebo response and remission rates varied according to which class of drug was being tested with the highest placebo response rates observed for biological drugs (genetically engineered medications made from living organisms). The highest placebo remission rates were observed for trials evaluating aminosalicylates (a type of antiinflammatory drug). The lowest placebo response and remission rates were in trials that assessed corticosteroids (drugs that suppress inflammation and immunity). The requirement of a minimum rectal bleeding score for study eligibility was associated with an increased placebo response rate compared to studies that did not use rectal bleeding for trial eligibility. The time point of primary outcome assessment was found to be significantly associated with placebo remission rates such that every one week increment in endpoint assessment was associated with an increase in the placebo remission rate. There were several trial design features that were associated with lower placebo response and remission rates. A key finding was that trials enrolling patients with more severe endoscopic disease (i.e. inflammation of the colon as confirmed by a colonoscopy) at trial entry were associated with lower placebo response and remission rates, which underpins the importance of objectively ensuring that patients enrolled into UC trials have sufficient disease severity. Disease duration of greater than five years prior to trial enrolment was associated with a significantly lower placebo response rate compared to disease duration of less than or equal to five years. The researchers also found that placebo rates have remained stable from 2008 to 2015.

In conclusion, placebo response and remission rates vary according to endoscopic disease severity and rectal bleeding score at trial entry, drug class, disease duration, and the time point at which the primary outcome was measured. The overall findings will help researchers conducting trials to design their studies, determine the number of patients required for their planned trials and also provide useful information about trial design features which should be considered when planning new trials.

\section{Description of the condition}


nal pain and fatigue. These symptoms can adversely affect schooling, work productivity, psychosocial well-being and collectively contribute to a substantially reduced health related quality of life. Medical approaches to disease management include corticosteroids, 5-aminosalicylates, immunosuppressants, tumour necrosis factor-alpha (factor- $\alpha$ ) antagonists and anti-integrin therapies. In randomised controlled trials (RCTs) patients assigned to placebo treatments improve on average. This placebo effect is a complex phenomenon and incompletely understood. Several factors have been proposed to explain the response to placebo which include regression to the mean, natural variation in the disease process, as well as environmental factors such as the patient-physician interaction and expectations of treatment benefit. Evidence from multiple therapeutic areas suggests that there are general trial design features capable of both attenuating and amplifying placebo response and remission rates (Enck 2013; See Table 1).

Whilst maximizing the placebo effect is desirable in clinical practice, in drug development the aim is to minimize this effect in order to best detect differences between drug and placebo that are attributable to treatment. Traditionally, there has been considerable variance in placebo response and remission rates across clinical trials of UC. Thus, understanding the factors which influence the placebo rate is essential to allow for more efficient study design. A meta-analysis published by $\mathrm{Su} 2007$ included 40 trials published up to 2005 in which patients with active UC received medical therapy or placebo. Factors such as number of follow-up visits and disease severity were found to influence placebo response and remission rates (Su 2007; See Table 2).

\section{Why it is important to do this review}

The last review of this topic was published in 2007 and presented an analysis of 40 trials conducted up to 2005 ( $\mathrm{Su} 2007$ ). The researchers identified a number of factors that influence placebo response and remission rates such as number of follow-up visits and disease duration. A decade has now elapsed since Su 2007 conducted their meta-analysis. During this period the design of clinical trials and RCTs has evolved. More objective markers of disease activity such as inflammation measured by endoscopic assessment are used to enrol patients in RCTs rather than more subjective measures of disease activity such as symptom-based diaries or disease activity indices.

Therapeutic trials for UC can be generally designed as induction, maintenance or integrated (incorporating both induction and maintenance phases) studies. While Su 2007 determined that study duration was positively associated with placebo remission rates, the meta-analysis did not explore whether trial phase influenced placebo response. It is plausible that placebo response will vary depending on whether the study is an induction, maintenance or integrated trial.

Su 2007 included studies if there was a placebo arm and all patients had active disease at entry. This meta-analysis reported the definitions of clinical response or remission used in each included study and the proportion of patients who achieved response or remission. In addition, the trials included in the review by $\mathrm{Su}$ 2007 assessed and pooled studies which used a variety of outcome measures to assess disease activity. For example, the outcome data from studies in which patients were enrolled and assessed using the Ulcerative Colitis Disease Activity Index (UCDAI), were pooled with outcomes from studies that used other disease activity indices (e.g. the Physician's Global Assessment (PGA) Scale and or the Rachmilewitz Index). To ensure that the measurement of patients' disease severity is similar across trials, the current review only included studies that utilized the UCDAI or the Mayo Score for enrolment and assessment. The UCDAI (Sutherland 1987a), and Mayo score (Schroeder 1987), are 12-point scales incorporating four components of disease activity (stool frequency, rectal bleeding, mucosal appearance on sigmoidoscopy and physicians global assessment). These scores are sufficiently similar to be considered equivalent. The establishment of a well-defined set of trial design criteria capable of consistently yielding accurate placebo response and remission rates in controlled trials of UC will aid in the interpretation of existing data and make it possible to design more efficient and cost-effective clinical trials and RCTs in the future.

\section{O B JE C T I VES}

The objective of this review is to conduct a meta-analysis of RCTs to quantify placebo rates of response and remission, how these have evolved over time, and to conduct a meta-regression to identify trial design features which affect the placebo response.

\section{METHODS}

\section{Criteria for considering studies for this review}

\section{Types of studies}

Placebo-controlled RCTs in UC incorporating an induction phase, maintenance phase or both and comparing an active drug with placebo were eligible for inclusion. A trial duration of a minimum of two weeks was required for induction trials, and four months for maintenance trials. Studies that did not use the UCDAI for enrolment and assessment were ineligible. Abstract publications were only included if sufficient information was provided in the abstract or authors could be contacted for further information. 


\section{Types of participants}

Adult patients (aged $\geq 18$ years) with active or quiescent UC defined by the UCDAI were considered for inclusion. Trials of hospitalised patients with UC were excluded.

\section{Types of interventions}

RCTs that compared corticosteroids, 5-aminosalicylates (5-ASA), immunosuppressants, tumour necrosis factor- $\alpha$ antagonists or other biologic agents to placebo were included. Trials of antibiotics, probiotics or complimentary therapies were excluded.

\section{Types of outcome measures}

\section{Primary outcomes}

The primary outcome measure was the proportion of patients in the placebo group achieving or maintaining clinical response or remission, as defined by the included studies and expressed as a percentage of the total number of patients randomised (i.e. intention-to-treat analysis).

\section{Secondary outcomes}

The secondary outcomes were the proportion of patients with endoscopic remission, endoscopic response, histological response and steroids free remission where reported.

\section{Search methods for identification of studies}

\section{Electronic searches}

We searched following databases for relevant studies:

1. MEDLINE (Ovid, 1946 to 1 March 2017);

2. EMBASE databases (1984 to 1 March 2017);

3. The Cochrane Central Register of Controlled Trials (1994 to 1

March 2017); and

4. The Cochrane IBD/FBD Group Specialized Trials Register (inception to 1 March 2017).

The search strategies are listed in Appendix 1.

\section{Searching other resources}

Manual searches of reference lists from potentially relevant trials and review articles were searched to identify additional studies. Abstracts from Digestive Disease Week and United European Gastroenterology Week were hand searched to identify studies reported in abstract form only.

\section{Data collection and analysis}

\section{Selection of studies}

Two authors (VJ and CP) independently screened titles and abstracts of publications identified by the literature search to determine eligibility based on the inclusion criteria described above (i.e. type of study, participants, and interventions). Disagreement was resolved by consensus.

\section{Data extraction and management}

A standardised data extraction form will was used to collect data from the included studies. The form was based on the Cochrane checklist of items to consider for data extraction (Higgins 2011a). Fourteen authors were paired into seven teams of two (TC and NA; TA and TA; PD and MA; MS and DH; AK and EM; MM and MA; SB and MG). Each team was provided a set of included studies from which they independently extracted data. Disagreement within each team was resolved through discussion until consensus was reached. Where consensus was not achieved, a third author (VJ or JKM) was consulted to resolve the disagreement. The authors of the original studies were contacted to provide further details in the case of unclear or missing data.

Data from five key areas were recorded from each included study as follows:

A. Trial design (publication year, number of treatment arms, trial phase, location, number of centres, number of patients randomised, blinding, number of screening visits, number of followup visits, frequency of follow-up visits, duration of follow-up visits, disease severity score used, minimum UCDAI inclusion score at entry, endoscopy sub-score for inclusion, bleeding sub-score for inclusion, definition of response, time point to measure response, definition of remission, time point to measure remission, whether endoscopy was performed at entry, whether active disease was confirmed by central reading, whether active disease was confirmed by histology at entry);

B. Participants (age, gender, disease severity at enrolment, C-reactive protein at entry, fecal calprotectin at entry, disease duration prior to enrolment, proportion of patients taking concurrent corticosteroids, proportion taking concurrent 5-ASA drugs, proportion taking concurrent immunosuppressive drugs, proportion taking concurrent biological agents, proportion who took biological agents in the past, proportion with proctitis, proportion with left-sided disease, proportion with extensive colitis or pancolitis); C. Interventions (drug name, route of administration, active comparator, dose of active comparator, frequency of placebo administrations, number of placebo administrations, ratio of active treatment versus placebo, frequency of active drug administrations); and

D. Outcomes (number of participants in placebo arm, intention-to-treat analysis, proportion of drop-outs post-randomisa- 
tion, number of patients in remission, proportion of patients in remission, number of patients with response, proportion of patients with response, proportion of patients in steroid-free remission, proportion of patients with mucosal healing, proportion with histological improvement).

\section{Assessment of risk of bias in included studies}

The Cochrane risk of bias tool was used assess the methodological quality of the included studies (Higgins 2011b) Fourteen reviewers were paired into seven teams of two (TC and NA; TA and TA; PD and MA; MS and DH; AK and EM; MM and MA; SB and $M G)$. Each team was provided a set of included studies for which they independently assessed the risk of bias. Disagreement within each team was resolved through discussion until consensus was reached. If the team was unable to reach consensus, a third author (VJ or JKM) was be consulted to resolve the disagreement. Factors assessed were:

1. Sequence generation (Selection bias);

2. Allocation concealment (selection bias);

3. Blinding of participants and personnel (performance bias);

4. Blinding of outcome assessment (detection bias);

5. Completeness of outcome data (attrition bias);

6. Selective reporting (reporting bias); and

7. Other sources of bias

These categories were rated as 'low risk', 'high risk' or 'unclear risk' for each study. Study authors were contacted if there was insufficient data to determine risk of bias.

We did not assess the overall quality of evidence using the GRADE approach since the current study is a meta-analysis of proportions analysing placebo response, rather than an interventionbased meta-analysis.

\section{Measures of treatment effect}

Proportions and corresponding 95\% confidence intervals (95\% CI) were calculated for dichotomous outcomes. The potential effects of study level variables on the proportions were quantified using odds ratios (OR).

\section{Unit of analysis issues}

Where response or remission are defined at multiple time points, the primary outcome as defined in the study was abstracted. Where the primary outcome was not defined the result from the final assessment time point was recorded. If any cross-over trials were included we extracted data from the first phase of the study only (i.e. before the cross-over occurred).

\section{Dealing with missing data}

Study authors were contacted to supply missing data or to explain the reason for data loss. Data were analysed according to the intention-to-treat principle. Data that remained missing were assumed to be negative (i.e. treatment failure).

\section{Assessment of heterogeneity}

Potential heterogeneity in placebo response and remission rates across studies was investigated by visual inspection of forest plots and by calculating the $\mathrm{Chi}^{2}$ (a P value of 0.10 will be regarded as statistically significant heterogeneity) and $\mathrm{I}^{2}$ statistics (Higgins 2002). If significant heterogeneity was present (i.e. $I^{2} \geq 50 \%$ ) we explored possible explanations using sensitivity analysis.

\section{Assessment of reporting biases}

Potential publication bias was assessed using funnel plots (Egger 1997a), and corrected using the trim and fill method if necessary (Duval 2000).

\section{Data synthesis}

The pooled proportions and corresponding 95\% CI of placebo response and remission rates were calculated using a binomial normal model for proportions (Stijnen 2010). Induction of remission and maintenance studies were pooled separately. Mixed-effects meta-regression was conducted as appropriate to assess the effects of study-level characteristics on placebo response and remission rates (Thompson 2002). The following study level characteristics were assessed: trial design features (including setting, design, country of origin, duration of follow up, number of study visits, time of outcome assessment, and publication date), inclusion criteria (including stringent versus less stringent criteria, disease severity, the presence of markers of active disease at enrolment, disease distribution, drug class, concomitant medications, and disease duration), and the assessment of response and remission (including stringent versus less stringent criteria and mucosal healing). P-values of less than 0.05 were regarded as statistically significant. Analyses were conducted using SAS 9.3 (SAS Institute, Cary, NC) and Stata 12.1 (STATA Corp).

\section{Subgroup analysis and investigation of heterogeneity}

Subgroup analyses were performed to examine the effects of:

1. Higher versus lower baseline disease activity inclusion scores

(i.e. moderate to severe disease versus mild to moderate disease);

2. Trials published after 2000 versus those published before 2000;

3. Class of drug; and

4. Use of endoscopic or histological criteria to define remission.

Placebo response and remission rates in randomised trials of induction and maintenance therapy for ulcerative colitis (Review) 


\section{Sensitivity analysis}

If sufficient data were available sensitivity analyses were conducted to determine the impact of excluding studies with lower methodological quality (i.e. trials with high or unclear risk of bias, trials with less than 50 patients and trials published in abstract form).

\section{Description of studies}

The literature search was conducted on 1 March 2017. There were 8977 reports identified through database searching and 12 reports identified from other sources.

\section{Results of the search}

After 3924 duplicates were removed, the titles and abstracts of 5056 reports were independently screened by two authors (VJ and $\mathrm{CP})$. Of these, 4811 reports were found to be non-applicable and 254 full-text reports were assessed for eligibility (see Figure 1).

\section{R E S U L T S}


Figure I. Study flow diagram.

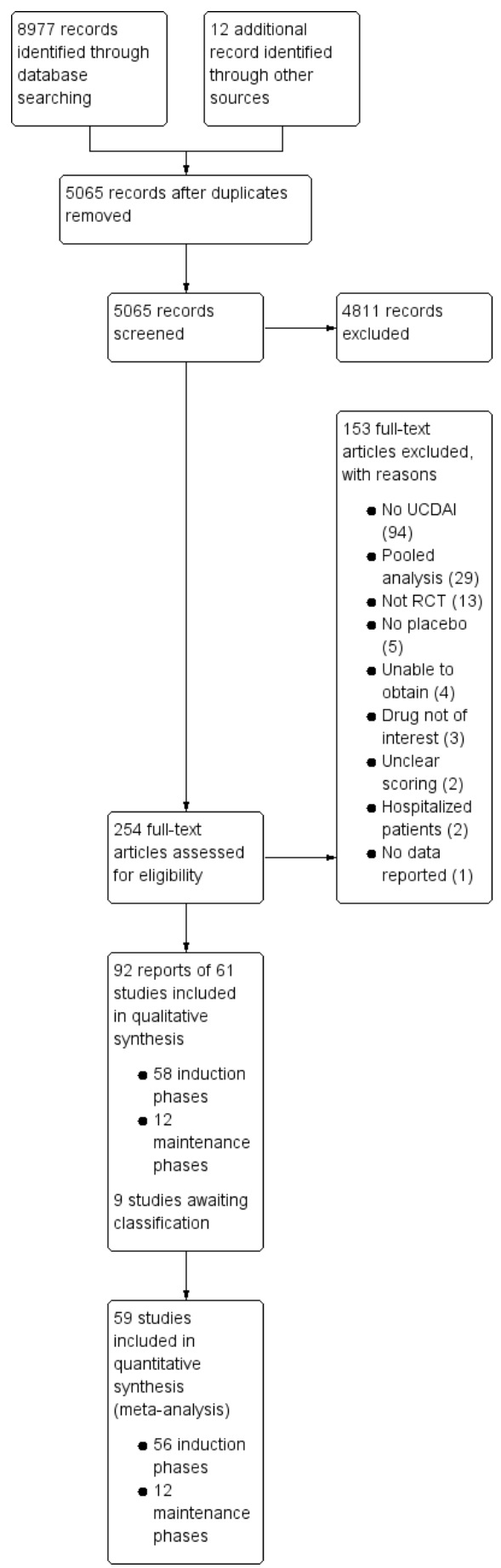




\section{Included studies}

Ninety-two reports of 61 studies met the inclusion criteria and were included in the review (See: Characteristics of included studies). The 61 included studies contained 58 induction phases and 12 maintenance phases. Two induction studies were reported in abstract form only and could not be included in the quantitative analysis (Aoyama 2015; Rubin 2015). Nine studies were identified that are awaiting classification and these studies will be considered for inclusion in a future update of this review (See Characteristics of studies awaiting classification).

Of the 56 induction phases $(\mathrm{n}=5111)$ that were included in the quantitative analysis, response rates were reported in 50 trials. Remission rates were reported in 47 trials. Of the 12 maintenance phases $(n=1338)$, response rates were reported in six trials and remission rates were reported in nine trials. Given the small number of maintenance phases, meta-regression to identify factors mediating placebo response rates was only conducted for induc- tion phases. Baseline characteristics of the included induction and maintenance studies are reported in Table 3 .

\section{Excluded studies}

One hundred and fifty-three studies were excluded, with reasons (See Characteristics of excluded studies). A total of 94 studies did not use the UCDAI for enrolment of patients and outcome assessment; 29 studies were pooled analyses using data from other studies; 13 studies were not randomised controlled trials; 5 studies had no placebo arm; 4 studies were unobtainable; 3 studies evaluated drugs that were not of interest; 2 studies did not clearly report how outcome evaluation was conducted; 2 studies included hospitalised patients; and 1 study did not report on outcomes of interest.

\section{Risk of bias in included studies}

The risk of bias assessment is summarized in Figure 2 . 
Figure 2. Risk of bias summary: review authors' judgements about each risk of bias item for each included study.

\begin{tabular}{|c|c|c|c|c|c|c|c|}
\hline & 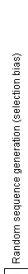 & 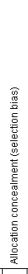 & & & 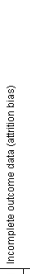 & & 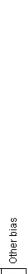 \\
\hline Aopama 2015 & 3 & 8 & 8 & (2) & \begin{tabular}{|l|l|}
8 \\
\end{tabular} & - & 0 \\
\hline Beeken 1997 & 3 & 2 & (3) & 3 & - & - & ๑ \\
\hline Carbonnel 2016 & 3 & 3 & 3 & 3 & \begin{tabular}{|c|}
3 \\
\end{tabular} & - & - \\
\hline Darese 2014 & 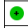 & - & ( & ? & - & - & • \\
\hline Deventer 2004 & 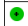 & - & ๑ & 3 & ๑) & - & $\oplus$ \\
\hline Deventer 2006 & 3 & 2 & ? & 3 & - & - & $\bullet$ \\
\hline Feagan 2000 & 3 & 3 & 3 & 3 & 3 & - & 3 \\
\hline Feagan 2005 & 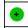 & (-) & • & $\odot$ & - & - & ๑ \\
\hline Feagan $2013 \mathrm{a}$ & $\oplus$ & • & ๑ & • & ? & ๑) & ๑ \\
\hline Feagan $2013 \mathrm{k}$ & - & ๑) & ๑ & $?$ & - & - & $\bullet$ \\
\hline Hanauer 2000 & 3 & 3 & • & 3 & - & - & 암 \\
\hline Jiang 2015 & 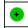 & - & 3 & ? & - & - & - \\
\hline Karmm 2007 & 3 & - & ๑) & ? & • & ๑) & क \\
\hline Lelper 2011 & • & - & $\oplus$ & ๑ & $\bullet$ & - & ๑ \\
\hline Lewis 2008 & - & - & 3 & 3 & - & - & - \\
\hline Lichtenstain 2007 & - & - & - & 3 & - & - & - \\
\hline Lichtenstein 2010 & 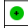 & 8 & ๑) & ๑ & - & - & ๑) \\
\hline Mareau 2005 & 9 & 2 & (?) & (2) & - & - & $\oplus$ \\
\hline Marer 2014 & 3 & - & - & 3 & - & - & - \\
\hline Nkolaus 2003 & - & - & 3 & 3 & - & - & - \\
\hline Ogsta 2006 & 3 & 3 & • & (3) & - & - & ๑ \\
\hline Dgsta 2012 & 3 & - & 8 & ๑) & 8 & - & ๑) \\
\hline Oren 1996 & 3 & $\bullet$ & ๑ & 2 & - & - & • \\
\hline Probert 2003 & - & - & 아 & 3 & - & - & () \\
\hline Reinisth 2011 & - & ๑) & • & ๑ & - & - & 3 \\
\hline Relinsth 2015 & 8 & 8 & 8 & 8 & - & • & 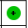 \\
\hline Rubin 2015 & 3 & 2 & (?) & ? & 3 & 3 & 3 \\
\hline Rutgerts $2005 a$ & - & - & 3 & 3 & - & - & - \\
\hline Rutgerts $2005 \mathrm{~b}$ & - & - & (3) & 3 & - & - & • \\
\hline Rutgents $2013 \mathrm{a}$ & $\oplus$ & ๑) & $\oplus$ & ? & - & • & ๑ \\
\hline Rutggens $2013 \mathrm{~b}$ & - & - & - & 3 & ๑ & 3 & (3) \\
\hline Rutyeents 2015 & - & - & 3 & 3 & - & - & - \\
\hline Sandborn 1994 & 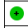 & 3 & - & ? & (-) & - & - \\
\hline Sanduarn 2003 & $\oplus$ & - & ๑ & (3) & (- & ๑ & ๑ \\
\hline sanoborm 20123 & $\oplus$ & (2) & $\oplus$ & 8 & (2) & 2 & 2 \\
\hline Sandborn $2012 b$ & - & - & 의 & 우 & - & - & - \\
\hline Sandborn $2012 c$ & - & () & 3 & 3 & - & (-) & (๑) \\
\hline Sandiborm 20120 & 3 & ๑) & (c) & ? & • & (3) & (3) \\
\hline Sandtacm $2013 \mathrm{a}$ (EUCF 3001$)$ & 8 & 2 & 8 & 2 & (2) & 2 & 2 \\
\hline Sandbom 2013b (EUCF F 3002) & 3 & 3 & ? & (3) & 3 & - & 3 \\
\hline Sandborm 20148 & - & - & 3 & ? & - & - & - \\
\hline Sandbarm $2014 \mathrm{~b}$ & 3 & 3 & ? & ? & ? & 3 & 3 \\
\hline Sandborn 2015 & 3 & $\oplus$ & ๑ & $?$ & (3) & (3) & 8 \\
\hline Sands 2012 & 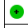 & $\bullet$ & $\oplus$ & $\oplus$ & - & 3 & ? \\
\hline Scher 2009 & 3 & - & • & 3 & - & - & - \\
\hline Schreiber 2007 & 3 & 3 & ๑) & ๑ & - & - & - \\
\hline Schroeder 1997 & $\bullet$ & $\oplus$ & $\oplus$ & ( & ? & - & $\oplus$ \\
\hline Sninskky 1931 & • & 2 & $\oplus$ & 3 & 3 & 3 & 3 \\
\hline Steirhat 1996 & 3 & (3) & 다 & 3 & - & - & 3 \\
\hline Sutherland 1987a & (ㄷ) & (ㄷ) & • & 3 & - & • & ๑) \\
\hline Suthererand $1987 \mathrm{~b}$ & $\oplus$ & (3) & $\oplus$ & (3) & ? & 3 & 8 \\
\hline Sutheranad 1990 & 3 & 8 & ๑ & $?$ & • & - & $\bullet$ \\
\hline ELuzuki 2014 & 3 & - & 3 & 3 & (-) & - & ๑ \\
\hline Suzukiti 2015 & 3 & 3 & 3 & ? & 3 & - & 3 \\
\hline Treals 2014 & $\oplus$ & ๑ & ๑) & + & • & - & ๑ \\
\hline Van Asccha 2006 & 8 & (2) & $\oplus$ & $?$ & ๑ & - & $\oplus$ \\
\hline Vermeire 2011 & 3 & - & 다 & $?$ & - (- & - & • \\
\hline Vermeire 2014 & 3 & - & 다 & • & - & - & () \\
\hline Wetanahe 2013 & - & (3) & ? & & • & - & ๑ \\
\hline Wwlllams 1987 & 8 & 8 & t. & $?$ & $\bullet$ & $\bullet$ & $\rightarrow$ \\
\hline & - & $\bullet$ & 하 & & • & • & $\oplus$ \\
\hline
\end{tabular}

Placebo response and remission rates in randomised trials of induction and maintenance therapy for ulcerative colitis (Review) 


\section{Allocation}

A total of 32 studies were rated as 'low risk of bias' and 29 studies were rated as 'unclear risk of bias' with respect to random sequence generation. For allocation concealment, 36 studies were rated as 'low risk of bias' and 25 studies were rated as 'unclear risk of bias'.

\section{Blinding}

Thirty-seven studies were rated as 'low risk of bias', and 24 studies were rated as 'unclear risk of bias' with regard to binding of study participants and personnel. Twelve studies were rated as 'low risk of bias' and 49 studies were rated as 'unclear risk of bias' with respect to blinding of outcome assessors.

\section{Incomplete outcome data}

For incomplete outcome, a total of 15 and 45 studies were rated as 'unclear risk of bias' and 'low risk of bias', respectively. One study was rated as 'high risk of bias'.

\section{Selective reporting}

A total of 51 studies were rated as 'low risk of bias' and 10 studies were rated as 'unclear risk of bias' with respect to selective reporting.

\section{Other potential sources of bias}

Forty-five studies were rated as 'low risk of bias' and 16 studies were rated as 'unclear risk of bias' for the 'other sources of bias' item.

\section{Effects of interventions}

For the 56 induction trials that were included in the quantitative analysis, the pooled estimate of placebo response was 33\% (95\% CI $30 \%$ to $36 \%$; Figure 3), while the pooled estimate of placebo remission was $12 \%$ (95\% CI $9 \%$ to $15 \%$; Figure 4 ). For maintenance trials, the pooled estimate of placebo response was $23 \%$ (95\% CI $19 \%$ to $28 \%$; Figure 5) while the pooled estimate of placebo remission was $17 \%$ (95\% CI $10 \%$ to $27 \%$; Figure 6). 
Figure 3. Response rates in induction phases.

Response [95\% Cl]

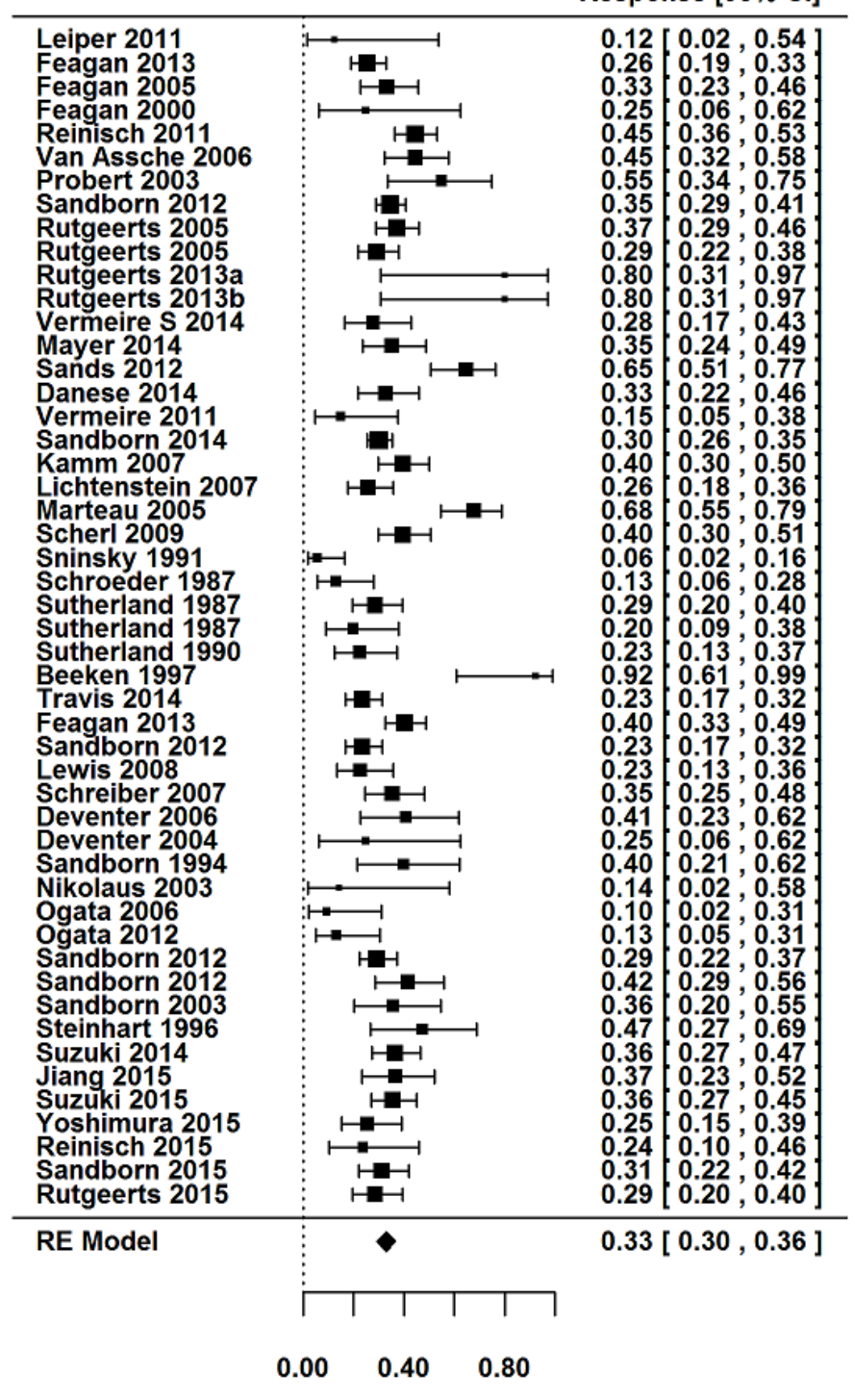

Response 
Figure 4. Remission rates in induction phases.

Remission $[95 \% \mathrm{Cl}]$

\begin{tabular}{|c|c|c|}
\hline $\begin{array}{l}\text { Leiper } 2011 \\
\text { Feagan 2013 } \\
\text { Feagan 2005 } \\
\text { Feagan 2000 } \\
\text { Reinisch 2011 } \\
\text { Van Assche 2006 } \\
\text { Probert 2003 } \\
\text { Sandborn 2012 } \\
\text { Rutgeerts 2005 } \\
\text { Rutgeerts 2005 } \\
\text { Rutgeerts 2013a } \\
\text { Rutgeerts 2013b } \\
\text { Vermeire S 2014 } \\
\text { Mayer 2014 } \\
\text { Sands 2012 } \\
\text { Danese 2014 } \\
\text { Vermeire 2011 } \\
\text { Sandborn 2014 } \\
\text { Kamm 2007 } \\
\text { Lichtenstein } 2007 \\
\text { Marteau 2005 } \\
\text { Scherl 2009 } \\
\text { Sninsky } 1991 \\
\text { Schroeder } 1987 \\
\text { Watanabe 2013 } \\
\text { Williams } 1987 \\
\text { Travis 2014 } \\
\text { Feagan 2013 } \\
\text { Sandborn 2012 } \\
\text { Lewis 2008 } \\
\text { Schreiber 2007 } \\
\text { Oren 1996 } \\
\text { Sandborn 1994 } \\
\text { Nikolaus 2003 } \\
\text { Ogata 2006 } \\
\text { Ogata 2012 } \\
\text { Sandborn 2012 } \\
\text { Sandborn 2012 } \\
\text { Sandborn 2003 } \\
\text { Steinhart } 1996 \\
\text { Suzuki 2014 } \\
\text { Suzuki 2015 } \\
\text { Carbonnel 2015 } \\
\text { Yoshimura 2015 } \\
\text { Reinisch 2015 } \\
\text { Sandborn 2015 } \\
\text { Rutgeerts 2015 }\end{array}$ & (1) & $\left.\begin{array}{l|l}0.12 & 0.02,0.54 \\
0.05 & 0.03,0.10 \\
0.14 & 0.08,0.25 \\
0.06 & 0.00,0.50 \\
0.09 & 0.05,0.16 \\
0.11 & 0.05,0.22 \\
0.30 & 0.14,0.53 \\
0.09 & 0.06,0.13 \\
0.15 & 0.10,0.22 \\
0.06 & 0.03,0.11 \\
0.20 & 0.03,0.69 \\
0.20 & 0.03,0.69 \\
0.01 & 0.00,0.16 \\
0.17 & 0.09,0.29 \\
0.27 & 0.17,0.41 \\
0.05 & 0.02,0.16 \\
0.02 & 0.00,0.29 \\
0.06 & 0.04,0.10 \\
0.22 & 0.15,0.32 \\
0.13 & 0.07,0.21 \\
0.34 & 0.23,0.47 \\
0.23 & 0.15,0.33 \\
0.02 & 0.00,0.12 \\
0.05 & 0.01,0.19 \\
0.17 & 0.10,0.28 \\
0.08 & 0.01,0.39 \\
0.03 & 0.01,0.08 \\
0.21 & 0.15,0.28 \\
0.07 & 0.04,0.13 \\
0.02 & 0.00,0.12 \\
0.06 & 0.02,0.16 \\
0.49 & 0.33,0.64 \\
0.05 & 0.01,0.28 \\
0.06 & 0.00,0.54 \\
0.05 & 0.01,0.27 \\
0.02 & 0.00,0.21 \\
0.26 & 0.19,0.34 \\
0.10 & 0.04,0.23 \\
0.11 & 0.03,0.28 \\
0.16 & 0.05,0.39 \\
0.11 & 0.06,0.20 \\
0.11 & 0.06,0.18 \\
0.24 & 0.14,0.37 \\
0.04 & 0.01,0.14 \\
0.10 & 0.02,0.31 \\
0.10 & 0.05,0.18 \\
0.10 & 0.05,0.19\end{array}\right]$ \\
\hline RE Model & $\checkmark$ & $0.12[0.09,0.15]$ \\
\hline
\end{tabular}

Remission 
Figure 5. Response rates in maintenance phases.

Respone $[95 \% \mathrm{Cl}]$

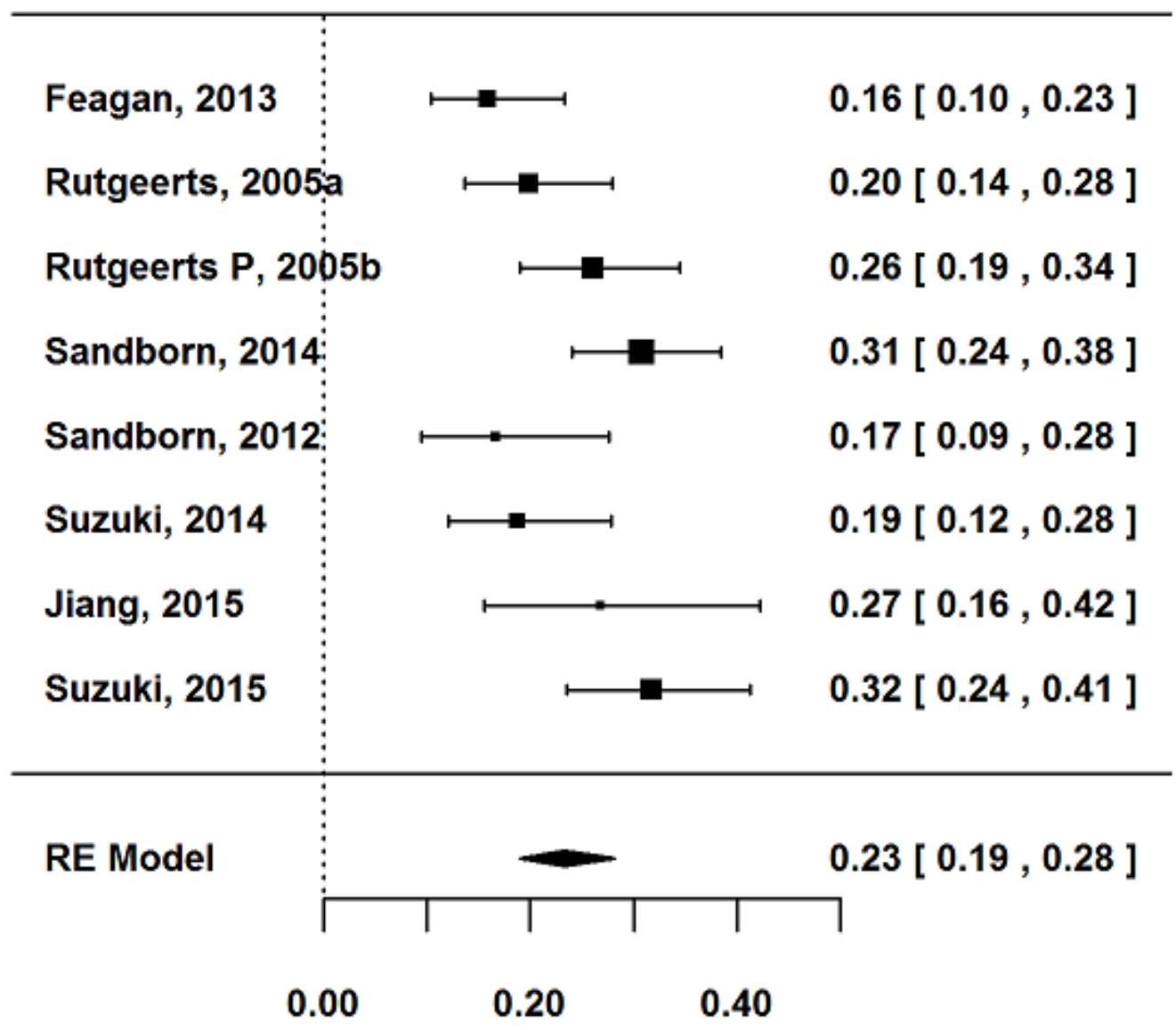

Response 
Figure 6. Remission rates in maintenance phases.

Remission $[95 \% \mathrm{Cl}]$

\begin{tabular}{|c|c|c|}
\hline Feagan 2013 & $\rightarrow$ & $0.16[0.10,0.23]$ \\
\hline Rutgeerts 2005a & -1 & $0.17[0.11,0.24]$ \\
\hline Rutgeerts P 2005b & $\rightarrow$ & $0.11[0.06,0.17]$ \\
\hline Sandborn 2014 & $n$ & $0.15[0.11,0.22]$ \\
\hline Hanauer 2000 & : & $0.09[0.03,0.24]$ \\
\hline Lichtenstein 2010 & $\longmapsto$ & $0.58[0.48,0.68]$ \\
\hline Oren 1996 & $\longmapsto$ & $0.27[0.15,0.43]$ \\
\hline Sandborn 2012 & $\mapsto$ & $0.14[0.07,0.24]$ \\
\hline Suzuki 2014 & : & $0.07[0.04,0.15]$ \\
\hline RE Model & & $0.17[0.10,0.27]$ \\
\hline
\end{tabular}

$\begin{array}{lll}0.00 & 0.40 & 0.80\end{array}$

Remission

Due to the relatively small number of maintenance trials, pooled remission rates according to stratum-specific variables and metaregression to identify factors influencing placebo rates were only conducted for induction trials.

Pooled remission rates according to stratum-specific variables are reported in Table 4 and results of the univariable meta-regression are reported in Table 5.
Determinants of placebo response rate in induction trials Participant and disease-related characteristics

A disease duration of greater than five years prior to study entry was associated with a significantly lower placebo response rate compared with a disease duration of less than or equal to five years (33\% versus $47 \%$ respectively; OR $0.54,95 \%$ CI 0.32 to 0.92 , P 
$=0.020$; Table 4; Table 5). Studies using an endoscopy sub score of greater than or equal to one for study entry were associated with a higher placebo response rate compared to studies using a more stringent entry criterion of an endoscopy sub score of greater than or equal to two ( $46 \%$ versus 34\%; OR $1.70,95 \%$ CI 1.02 to $2.82, \mathrm{P}=0.02$ ). Studies requiring a minimum rectal bleeding sub score for study entry compared with those not requiring a minimal rectal bleeding sub score were associated with a higher placebo rate (37\% versus $32 \%$; OR $1.7,95 \%$ CI 1.02 to $2.82, \mathrm{P}=0.02$ ).

There were no statistically significant differences in placebo response rates observed between study-defined clinical disease severity (mild-moderate versus moderate-severe) duration of follow up (less than or equal to eight weeks versus greater than eight weeks), date of publication (before and including 2007 versus after 2007), composite UCDAI score for trial eligibility (greater than or equal to six versus less than six) or the time point for the outcome measure of response (greater than six weeks versus less than six weeks; Table 4; Table 5).

Trial design and setting

There were no statistically significant differences in placebo response rates between multicenter multinational induction trials compared to multicenter single country induction trials (35\% versus $29 \%$, respectively; OR $1.39,95 \%$ CI 0.96 to $2.03, \mathrm{P}=0.16$ ), integrated (i.e. trials with induction and maintenance phases) compared to stand-alone induction trials (32\% versus $34 \%$, respectively; OR $0.86,95 \% \mathrm{CI} 0.61$ to $1.22, \mathrm{P}=0.40$ ), induction trials published before or after 2007 (33\% for both time periods; OR $0.96,95 \%$ CI 0.70 to $1.33, \mathrm{P}=0.81$ ), when the first author on the publication was from Europe compared to North America (37\% versus $32 \%$; OR $1.28,95 \%$ CI 0.90 to $1.81, \mathrm{P}=0.24$ ), or according to number of follow-up visits (OR 1.05, 95\% CI 0.70 to 1.57 per visit increment), or duration of follow-up (OR 0.88 , 95\% CI 0.57 to 1.37 per 1 week increment).

\section{Class of drug}

Pooled placebo response rates according to class of drug ranged from $19 \%$ to $35 \%$ (Table 4). The lowest placebo response rate (19\%; $95 \%$ CI $7 \%$ to $43 \%$; $\mathrm{P}=0.04$ ) was observed for trials of immunosuppressants whereas the highest placebo response rate (35\%, 95\% CI $31 \%$ to $38 \%$; $\mathrm{P}<0.001$ ) was observed for trials of biological drugs. Trials of orally administered agents had the lowest placebo response rate $(28 \%$; OR $0.58,95 \%$ CI 0.35 to $0.98)$ compared to trials of topically administered agents which had the highest placebo response rate (39\%; $95 \%$ CI $27 \%$ to $53 \%$; $\mathrm{P}=0.12$ for the comparison).

Time trends in placebo rates

Cumulative meta-analysis indicated a steady rise in the placebo response rate from 1987 to 2007 (from 13\% to 33\%) with rates remaining constant from 2008 to 2015 (32\% to 34\%; Figure 7). The difference between the 1987 to 2007 and 2008 to 2015 point estimates for response $(\mathrm{p}=0.81)$ was not statistically significant (Table 5). 
Figure 7. Cumulative placebo response rates 1987-20I5.

Response $[95 \% \mathrm{Cl}]$
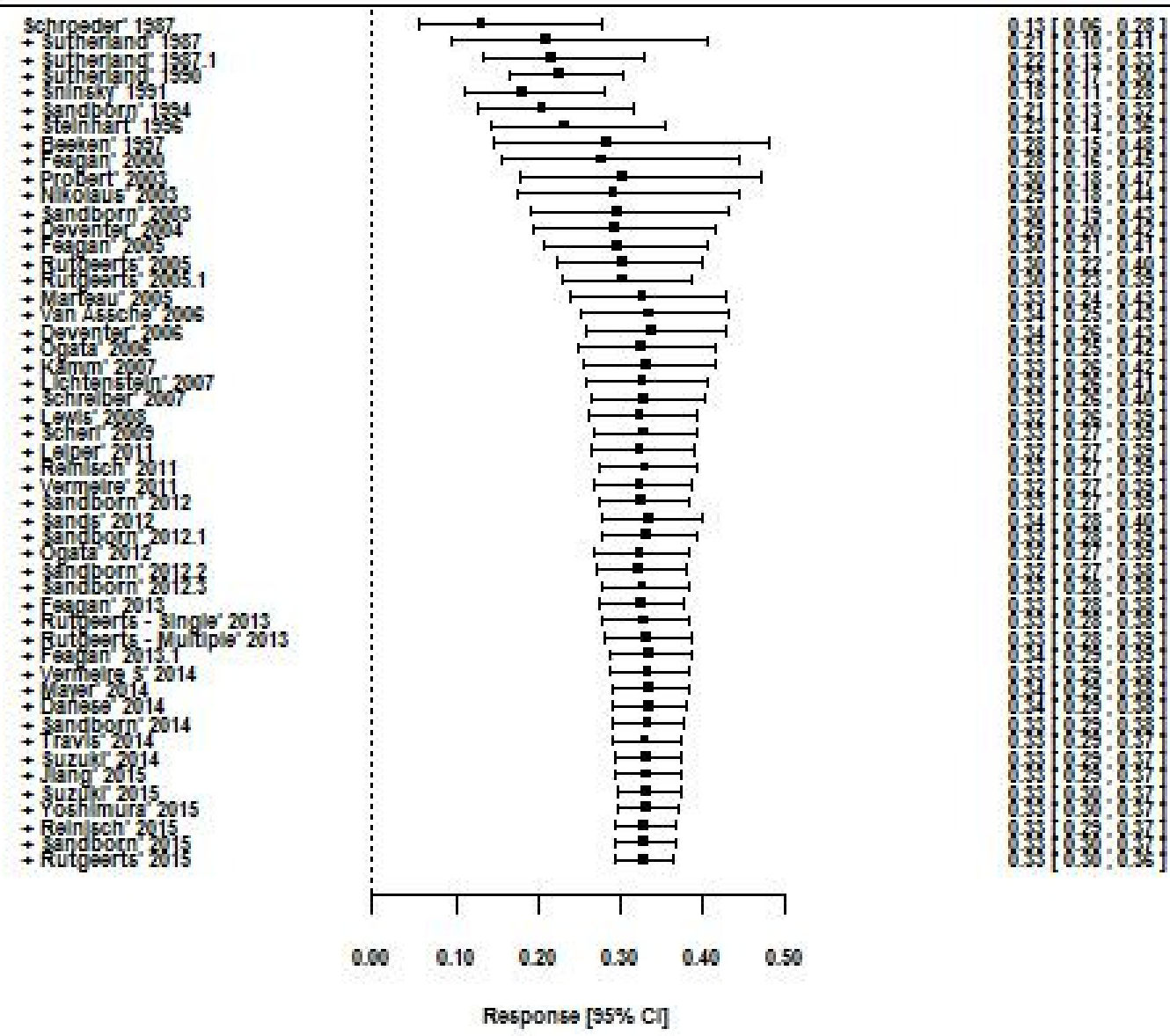

Determinants of placebo remission rate in induction trials Participant-and disease-related characteristics

Studies using an endoscopy sub score of greater than or equal to one for study entry were associated with a higher pooled placebo remission rate compared to studies using a more stringent criteria of an endoscopy sub score of greater than or equal to two $(27 \%$ versus $4 \%$; OR $2.60,95 \%$ CI 1.25 to $5.42, \mathrm{P}=0.01$; Table 4; Table 5).

No statistically significant differences were observed for the pooled placebo remission rates according to the requirement for disease duration (greater than 5 years prior to study entry versus less than or equal to five years), a minimum rectal bleeding sub score for study entry (required versus not required), study-defined disease severity (mild-moderate versus moderate-severe), composite UCDAI score for trial eligibility (greater than or equal to six versus less than six), duration of follow up (less than or equal to eight weeks versus greater than eight weeks), date of publication (before than and including 2007 versus after 2007), or the time point for the outcome measure of response (greater than six weeks versus less than six weeks; Table 4; Table 5).

\section{Trial design and setting}

The time point of primary outcome assessment was found to be significantly associated with placebo remission rates (OR 1.06, 
95\% CI 1.02 to $1.10, \mathrm{P}=0.01$; per one week increment).

There were no significant differences in placebo remission rates observed between multicenter multinational induction trials compared to multicenter single country induction trials $(12 \%$ versus $11 \%$, respectively; OR $1.11,95 \%$ CI 0.64 to $1.94, \mathrm{P}=0.59$ ), integrated (i.e. induction and maintenance trials) compared to standalone induction trials ( $12 \%$ versus $35 \%$, respectively; OR 1.21 , $95 \%$ CI 0.70 to $2.07, \mathrm{P}=0.50$ ), induction trials published before or after 2007 (13\% versus 11\%, respectively; OR 0.77, 95\% CI 0.47 to $1.29, \mathrm{P}=0.32$ ), when the first author on the publication was from Europe compared to North America (12\% versus 11\%; OR $1.15,95 \%$ CI 0.66 to $2.01, \mathrm{P}=0.80$ ), or according to number of follow-up visits (OR 1.08, 95\% CI 0.55 to 2.12 per visit increment), or duration of follow-up (OR 1.41, 95\% CI 0.77 to 2.58 per 1 week increment).

Class of drug

Pooled remission rates according to class of drug class ranged from $5 \%$ to $18 \%$ (Table 4 ). The lowest placebo remission rate was ob- served for trials of corticosteroids (5\%; $95 \%$ CI $2 \%$ to $11 \%$; $\mathrm{P}=$ $0.48)$ whereas the highest placebo remission rate $(18 \%$; $95 \% \mathrm{CI}$ $12 \%$ to $24 \%$; $\mathrm{I}^{2}=0.005$ ) was observed for trials of aminosalicylates $(18 \%$; $95 \%$ CI $12 \%$ to $24 \%$; $\mathrm{P}=0.005)$. Aminosalicylate trials were associated with an increase in the placebo remission rate (OR 3.95, 95\% CI 1.37 to $11.49, \mathrm{P}=0.02$; baseline comparator corticosteroids) as were immunosuppressant trials (OR 4.95, 95\% CI 1.47 to $16.73, \mathrm{P}=0.02$; baseline comparator corticosteroids). Time trends in the placebo rates

Cumulative meta-analyses suggest that placebo response rates in UC trials increased from 1987 to 2007 (13\% to 33\%), but remained constant from 2008 to 2015 (32\% to 34\%; Figure 7). Similarly, placebo remission rates increased from 1987 to 2007 ( $5 \%$ to $14 \%$ ) but have remained relatively constant between $12 \%$ to $14 \%$ from 2008 to 2015 (Figure 8). The difference between the 1987 to 2007 and 2008 to 2015 point estimates for remission (P $=0.32$ ) was not statistically significant. 
Figure 8. Cumulative placebo remission rates 1987-2015.

Response [95\% Cl]

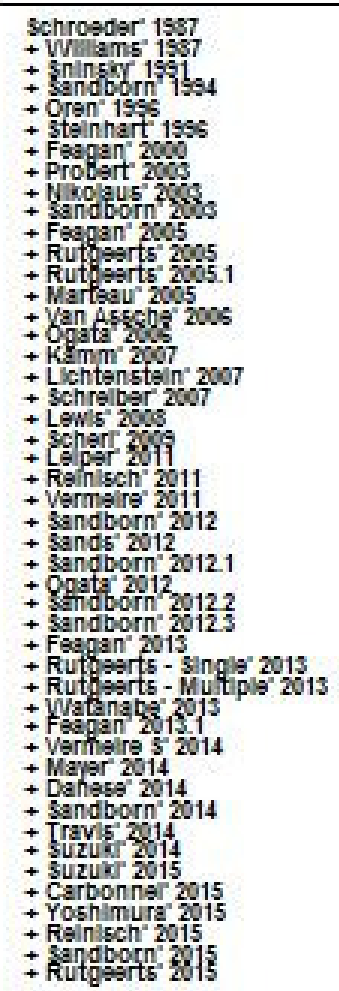
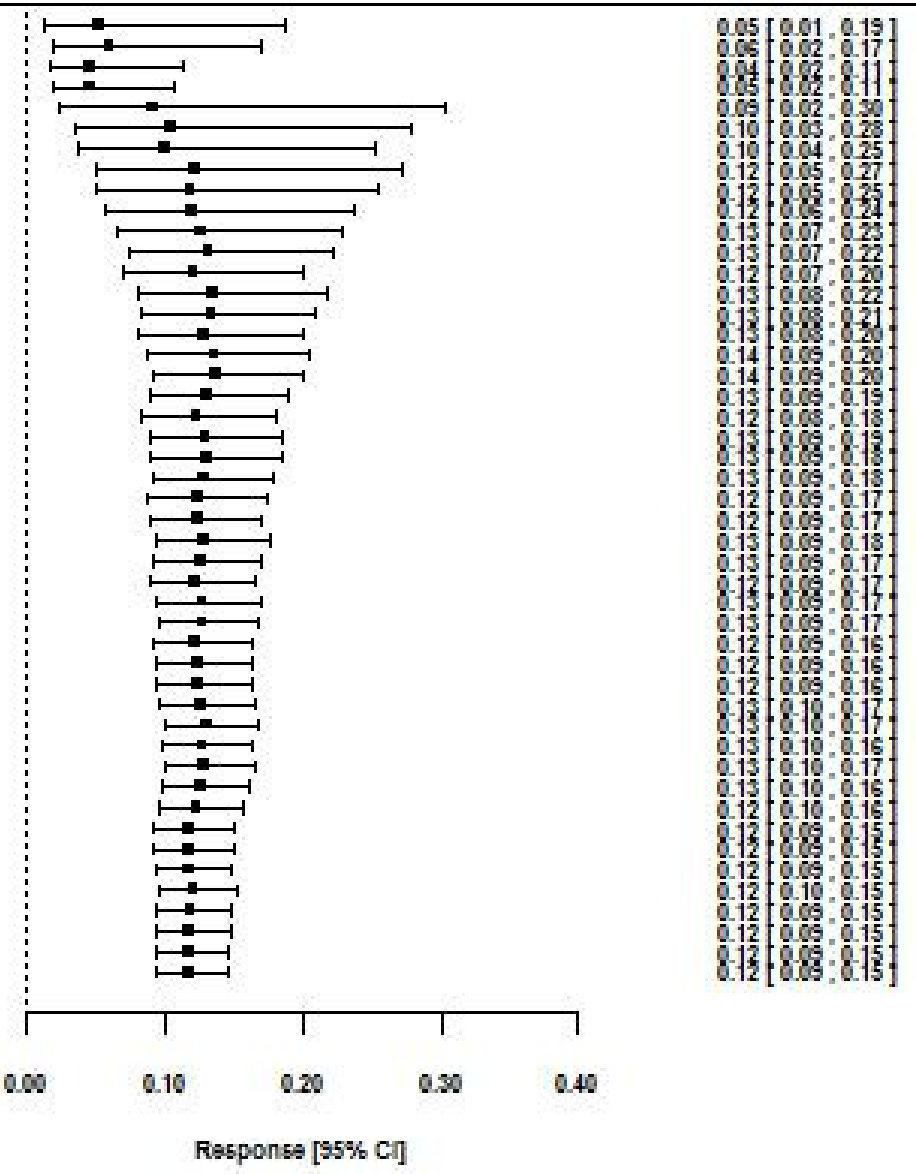

\section{Publication bias}

The regression test for funnel plot asymmetry demonstrated that there was no significant risk of publication bias for induction trials reporting on response $(P=0.6$; Figure 9$)$ or remission $(P=0.25$; Figure 10)). Publication bias was not explored for maintenance of remission due to a limited number of studies. 
Figure 9. Funnel plot test for asymmetry: response

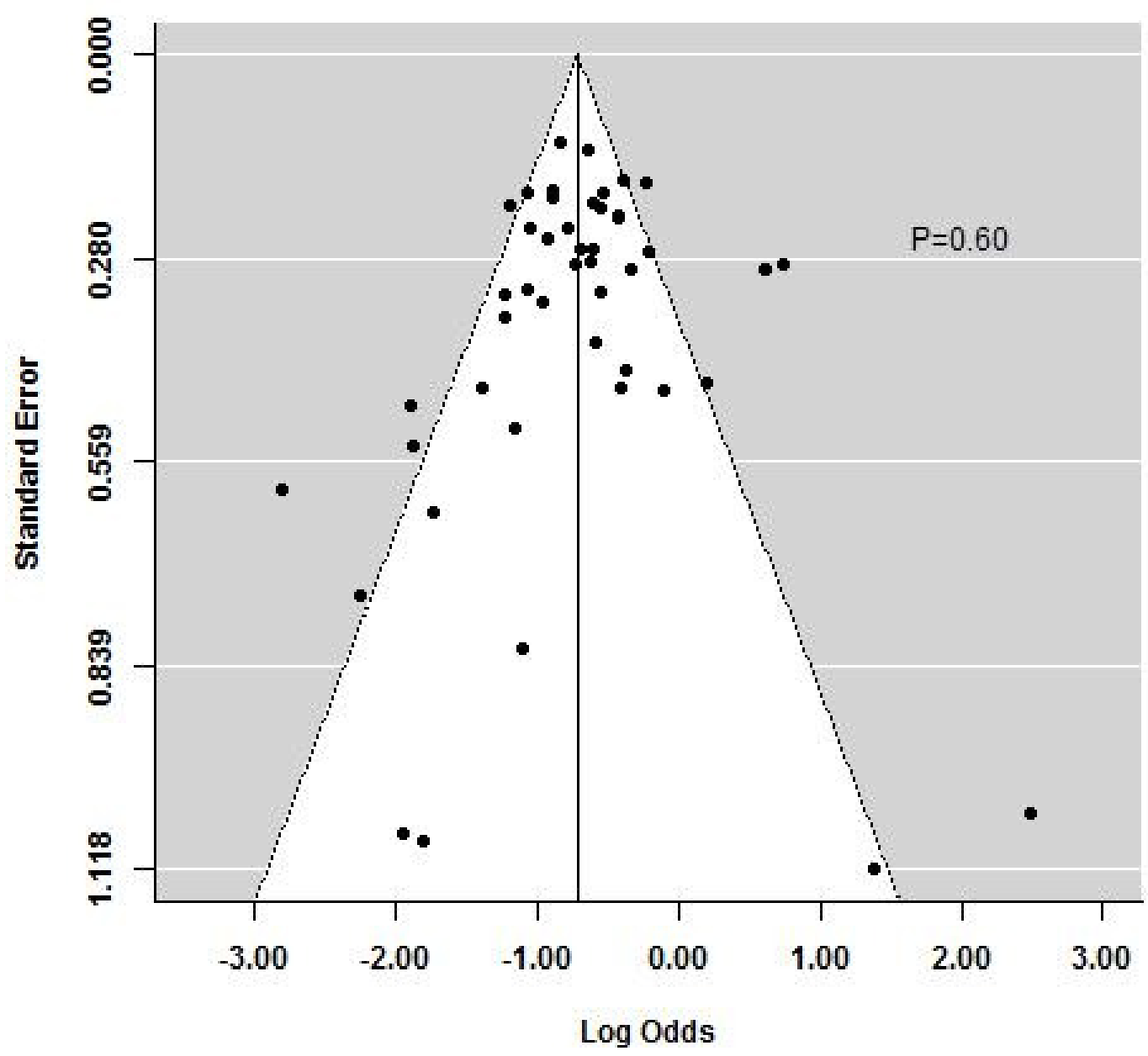

Placebo response and remission rates in randomised trials of induction and maintenance therapy for ulcerative colitis (Review) 
Figure 10. Funnel plot test for asymmetry: remission

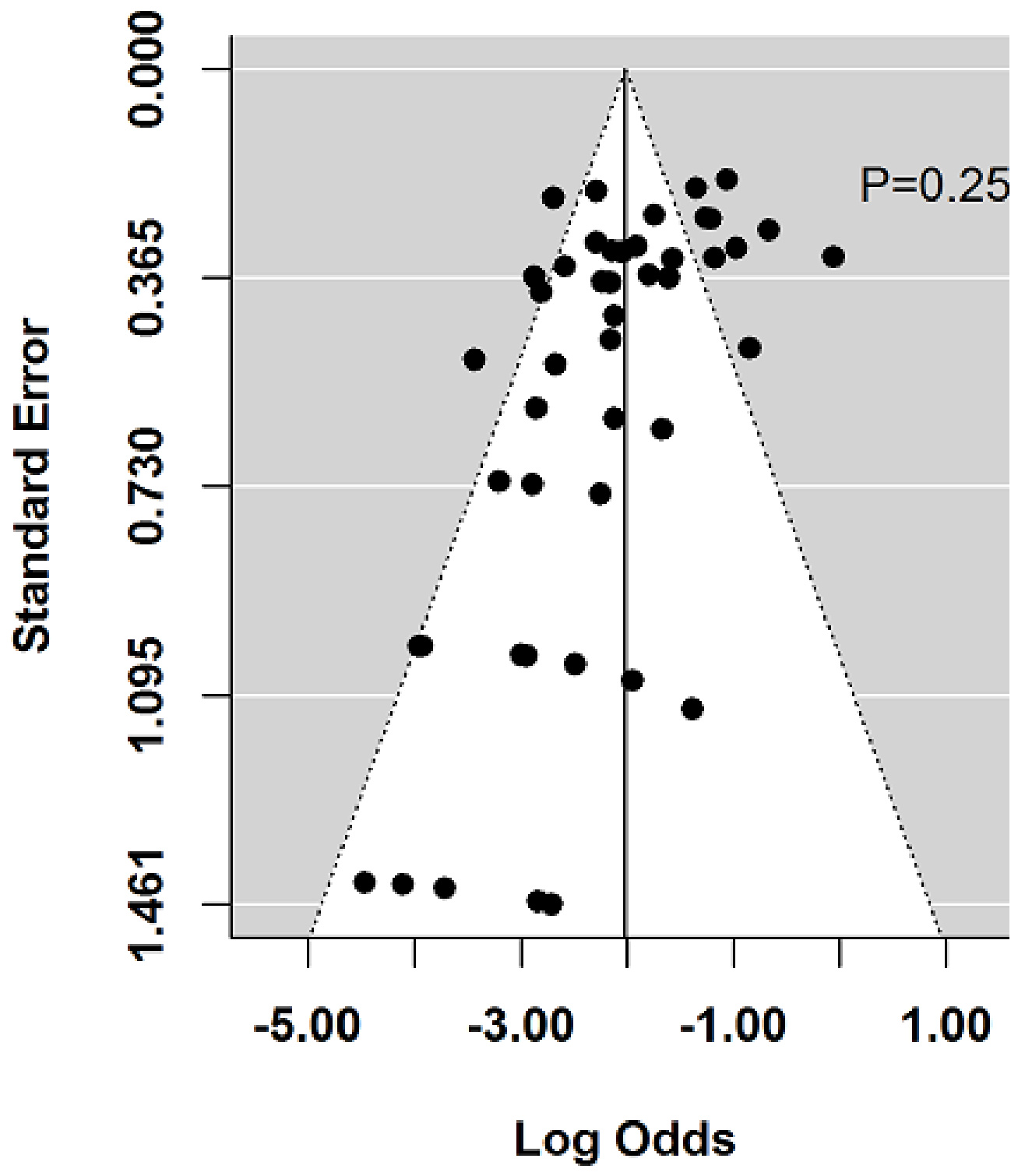

Placebo response and remission rates in randomised trials of induction and maintenance therapy for ulcerative colitis (Review) 


\section{DISCUSSION}

\section{Summary of main results}

Multiple factors influence the response to placebo, including the type of intervention, route of administration, frequency of dosing, patient expectations, patient-provider relationship, behavioural condition and clinical setting (Dieppe 2013). Understanding modifiers of placebo response in UC trials has important implications for trial design and interpretation.

In the current systematic review and meta-analysis, we identified 92 reports of 61 placebo-controlled UC studies, comprised of 58 induction phases and 12 maintenance phases. Two of the induction studies were solely reported in abstracts that did not provide sufficient data and were therefore excluded from the quantitative analysis (Aoyama 2015; Rubin 2015), leaving 56 induction phases $(\mathrm{n}=5111)$ and 12 maintenance phases $(\mathrm{n}=1338)$ available for pooling.

One of our key findings was that trials which enrolled patients with more active disease confirmed objectively by endoscopy were associated with significantly lower placebo remission and response rates than trials enrolling patients with less active disease $(27 \%$ versus $4 \%$; OR $2.60,95 \%$ CI 1.25 to $5.42, \mathrm{P}=0.01$ for UCDAI endoscopy sub score greater than or equal to one versus greater than or equal to two for remission; and $27 \%$ versus $4 \%$; OR 1.70 , $95 \%$ CI 1.02 to $2.82, \mathrm{P}=0.02$ for UCDAI endoscopy sub score greater than or equal to one versus greater than or equal to two for response). These results underscore the importance of ensuring that patients enrolled into clinical trials have objective confirmation of disease severity. This phenomenon was first demonstrated on post-hoc analysis of an RCT of mesalamine where restricting analysis of the primary outcome to patients who were adjudicated to have sufficiently active disease at trial entry by an independent central assessor (Mayo endoscopy subscore greater than or equal to two) led to a significant reduction in placebo remission rates (20.6\% versus $13.8 \%$; Feagan 2013a). In that trial, no such outcome was seen when using symptom based criteria such as stool frequency or rectal bleeding, indicating endoscopy as a more important factor to define disease severity at trial entry. This discrepancy between patient reported symptoms and endoscopy is well recognised and this phenomenon is supported by the current meta-analysis in which more severe endoscopic disease activity at baseline was associated with lower placebo rates, whereas the converse was seen with rectal bleeding subscore, likely a reflection of the greater reliability of endoscopic measurement compared to symptoms.

Placebo rates varied according to whether trials were designed as induction of remission studies or as maintenance of remission studies. This is an important differentiation for planning trials, since UC trials are still most commonly designed as stand-alone induction studies, typically of shorter duration up to 8 weeks, or stand-alone maintenance studies of longer duration, typically up to 52 weeks. Trial duration is an important influencing factor, since we observed a $6 \%$ increase in the odds of placebo remission rate per week of follow-up. These findings are supported by the theory that increasing patient assessment and patient-provider interactions has a positive impact upon disease course, and that with time, there is a greater chance of spontaneous improvement in disease state as well as regression towards the mean. Thus, standardization of trial assessments is an important factor to consider to reduce the placebo response rate.

A disease duration of greater than five years prior to enrolment was significantly associated with a lower placebo response rate compared to a disease duration of less than or equal to five years ( $29 \%$ versus $47 \%$, respectively; OR $0.54,95 \%$ CI 0.32 to 0.92 , P $=0.02$ ). This observation is most likely due to a lower likelihood of achieving spontaneous remission with more established disease ( $29 \%$ versus $47 \%$, respectively; OR $0.54,95 \%$ CI 0.32 to $0.92, \mathrm{P}$ $=0.02$ ). Class of drug was also an important factor with the highest rates of placebo response observed for biological drugs, perhaps related to a behavioral or 'response' expectancy to the most potent class of therapeutic agents.

Significant heterogeneity was observed for both induction and maintenance trials when pooled for response and remission, despite stratification across several covariates. This was somewhat surprising, since the study eligibility criteria were restricted to only include trials which used the UCDAI for enrolment or outcome assessment. These data highlight that there are many other factors which contribute to trial heterogeneity which include patient demographics, patterns of disease, timing and methods of outcome assessment.

\section{Overall completeness and applicability of evidence}

There were insufficient trials available to evaluate the effect of study-level characteristics on placebo rates for maintenance studies. Furthermore, we were not able to evaluate the impact of central reading of endoscopy on placebo rates due to insufficient data. Only one of the trials utilized this approach (Feagan 2013a). It should also be noted that statistically significant heterogeneity was detected when data were pooled in some instances (see Table 4 for specific $\mathrm{I}^{2}$ values). Finally, while detailed analyses were performed using pooled data, the optimum method to investigate the influence of specific patient characteristics on placebo rates is by analysing patient-level data.

Placebo response and remission rates in randomised trials of induction and maintenance therapy for ulcerative colitis (Review) 


\section{Quality of the evidence}

The Cochrane risk of bias tool was used to assess the quality of the individual studies included in this review. The majority of studies received ratings of 'low risk of bias' or 'unclear risk of bias' on trial design features related to selection, performance, detection, attrition and reporting bias. Given that the current review was a metaanalysis of proportions rather than an intervention-based review, the GRADE approach was not applied to assess the overall quality of evidence supporting the primary and secondary outcomes.

\section{Potential biases in the review process}

There were a limited number of maintenance trials that met the inclusion criteria, therefore we did not evaluate the effect of studylevel characteristics on the placebo rates reported in studies. Furthermore, central reading of endoscopy was only performed in one included study, which prevented us from exploring the impact of this design feature on placebo rates. Third, there was some evidence of statistically significant heterogeneity when the data were combined. Finally, despite the detailed analyses performed in the current study, the optimal method for examining the impact of demographic characteristics on placebo rates is through the use of patient-level data.

\section{Agreements and disagreements with other studies or reviews}

A similar meta-analysis on placebo response and remission rates conducted by Su 2007 identified 12 UC trials performed prior to 2005. However, the current analysis included more than 40 trials published after 2005, for a total of 61 trials, all of which used the UCDAI for baseline and outcome assessment. Furthermore, the current systematic review separately analysed the induction and maintenance phases, thus providing new data on these specific areas of trial design.

Our review had some similar results to those reported by Su 2007 insofar as duration of disease and the inclusion of baseline rectal bleeding scores were significantly associated with placebo response and remission rates, respectively. Su 2007 also found that studies conducted in Europe were associated with placebo remission rates, however this relationship was not observed in our review.

Consistent with an earlier version of the current systematic review (Jairath 2016), we observed that disease duration at entry was significantly associated with placebo response rates and endoscopic disease activity was significantly associated with placebo remission rates. The current version of this review also determined that endoscopic disease activity was significantly associated with placebo response, the time point at which the primary outcome was measured was significantly associated with placebo remission rates, and as mentioned above, baseline rectal bleeding scores were significantly associated with placebo remission rates.

\section{A UTHORS'CONCLUSIONS}

\section{Implications for practice}

The results of the current review indicate that placebo response and remission rates vary according to endoscopic severity of disease at entry, minimum rectal bleeding score at entry, the class of agent being evaluated, disease duration, and the time point at which the primary outcome was measured. These findings highlight the fact that several factors should be considered during trial design in an attempt to minimize placebo rates.

The observation that higher endoscopic disease activity at entry is associated with lower placebo response and remission rates highlights the critical importance of qualifying patients into clinical trials through objective measurement of disease activity with endoscopy. This is in line with evidence from other therapeutic areas suggesting that placebo responses are more pronounced in trials in which outcomes are measured by patient reported outcomes alone, rather than more objective evaluations by physicians (Enck 2013; Rief 2009).

It is possible that the data presented in this meta-analysis could be used to inform prior probability distributions for placebo treatment effects in early trial designs using Baysian statistics (Schmid 2004). This has the potential to reduce the number of required trial participants.

\section{Implications for research}

Only one of the trials included in the current review used central reading of endoscopy for outcome evaluation, therefore this variable could not be meta-analysed or incorporated into the metaregression model. Future updates of this review may be able to explore the relationship between central reading of endoscopy and placebo rates as more RCTs incorporating blinded endoscopic outcome assessment are published.

\section{ACKNOWLEDGEMENTS}

Partial funding for the Cochrane IBD Group (April 1, 2016 March 31, 2018) has been provided by Crohn's and Colitis Canada (CCC). 


\section{R E F E R E NCES}

\section{References to studies included in this review}

Aoyama 2015 \{published data only\}

Aoyama N, Suzuki Y, Nishino H, Kobayashi K, Hirai F,

Watanabe $\mathrm{K}$, et al. Twice-daily budesonide rectal foam induces complete mucosal healing in Japanese patients with mild to moderate ulcerative colitis: Results of multicenter, randomized, double-blind, placebo-controlled trial. Journal of Crohn's and Colitis 2015;9:S359.

Beeken 1997 \{published data only\}

Beeken W, Howard D, Bigelow J, Trainer T, Roy M, Thayer W, et al. Controlled trial of 4-ASA in ulcerative colitis. Digestive Diseases and Sciences 1997;42:354-8.

Carbonnel 2016 \{published data only\} Carbonnel F, Colombel JF, Filippi J, Katsanos K, PeyrinBiroulet L, Allez M, et al. Methotrexate for corticosteroiddependent ulcerative colitis: Results of a placebo randomized controlled trial. Gastroenterology 2016;1:S140. Carbonnel F, Colombel JF, Filippi J, Katsanos K, PeyrinBiroulet L, Allez M, et al. Methotrexate for corticosteroiddependent ulcerative colitis: Results of a placebo randomized controlled trial. Journal of Crohn's and Colitis 2015;9:S14-5.

* Carbonnel F, Colombel JF, Filippi J, Katsanos KH, PeyrinBiroulet L, Allez M, et al. Methotrexate is not superior to placebo for inducing steroid-free remission, but induces steroid-free clinical remission in a large proportion of patients with ulcerative colitis. Gastroenterology 2016;150 (2):380-8.

Danese 2014 \{published data only\}

Danese S, Rudzinski J, Brandt W, Dupas JL, PeyrinBiroulet L, Bouhnik Y, et al. Tralokinumab (CAT-354), an interleukin 13 antibody, in moderate to severe ulcerative colitis: A phase 2 randomized placebo-controlled study. Journal of Crohn's and Colitis 2014;8:S7-8.

* Danese S, Rudzinski J, Brandt W, Dupas JL, PeyrinBiroulet L, Bouhnik Y, et al. Tralokinumab for moderate-tosevere UC: a randomised, double-blind, placebo-controlled, phase IIa study. Gut 2014;64(2):243-9.

Deventer 2004 \{published data only\}

Deventer SJ, Tami JA, Wedel MK. A randomised, controlled, double blind, escalating dose study of alicaforsen enema in active ulcerative colitis. Gut 2004; Vol. 53: $1646-51$.

Deventer 2006 \{published data only\}

Deventer SJ, Wedel MK, Baker BF, Xia S, Chuang E, Miner PB. A phase II dose ranging, double-blind, placebocontrolled study of alicaforsen enema in subjects with acute exacerbation of mild to moderate left-sided ulcerative colitis. Alimentary Pharmacology and Therapeutics 2006; Vol. 23: 1415-25.

Feagan 2000 \{published data only\}

Feagan B, McDonald JWD, Greenberg G, Wild G, Pare P, Fedorak RN, et al. An ascending dose trial of a humanised a 4 b7 antibody in ulcerative colitis. Gastroenterology 2000; 118(4 Suppl 2):A874.

Feagan 2005 \{published data only\}

* Feagan BG, Greenberg GR, Wild G, Fedorak RN, Pare P, McDonald JW, et al. Treatment of ulcerative colitis with a humanized antibody to the alpha4beta7 integrin. New England Journal of Medicine 2005;352:2499-507.

Feagan BG, McDonald JWD, Greenberg G, Wild G, Pare P, Fedorak RN, et al. An ascending dose trial of a humanized A4B7 antibody in ulcerative colitis (UC). Gastroenterology 2000;118:A874.

Feagan 2013a \{published data only\}

Feagan BG, Mittmann U, Gilgen D, Wong CJ, Mikhailova E, Levchenko O, et al. A randomised placebo-controlled double-blind study of Octasa $4.8 \mathrm{~g} /$ day $(800 \mathrm{mg}$ tablets 5ASA) for the induction of endoscopic remission in patients with active ulcerative colitis. Gut 2012;61:A170.

* Feagan BG, Sandborn WJ, D'Haens G, Pola S, McDonald JW, Rutgeerts P, et al. The role of centralized reading of endoscopy in a randomized controlled trial of mesalamine for ulcerative colitis. Gastroenterology 2013;145:149-57.

\section{Feagan 2013b \{published data only\}}

Feagan B, Colombel JF, Rubin D, Mody R, Sankoh S, Lasch $\mathrm{K}$. Improvements in health-related quality of life in patients with ulcerative colitis treated with vedolizumab. Journal of Crohn's and Colitis 2014;8:S51-2.

Feagan B, Rutgeerts P, Sands B, Sandborn W, Colombel JF, Hanauer S. Vedolizumab maintenance therapy for ulcerative colitis: Results of gemini I, a randomized, placebo-controlled, double-blind, multicenter phase 3 trial. American Journal of Gastroenterology 2012;107:S609-10. Feagan B, Sandborn WJ, Smyth M, Sankoh S, Parikh A, Fox I. Effects of continued vedolizumab therapy for ulcerative colitis in week 6 induction therapy nonresponders. Journal of Crohn's and Colitis 2014;8:S276-7.

Feagan B, Sands B, Sankoh S, Milch C, Fox I. Efficacy of vedolizumab in ulcerative colitis by prior treatment failure in GEMINI I, a randomised, placebo-controlled, doubleblind, multi-centre trial. Journal of Crohn's and Colitis 2013; 7:S216.

Feagan B, Sands B, Sankoh S, Milch C, Fox I. Efficacy of vedolizumab in ulcerative colitis by prior treatment failure in gemini $\mathrm{i}$, a randomized, placebo-controlled, doubleblind, multicenter trial. Inflammatory Bowel Diseases 2012; 18:S1-2.

Feagan BG, Colombel JF, Rubin DT, Mody R, Sankoh S, Lasch K. Health-related quality of life in patients with ulcerative colitis after treatment with vedolizumab: Results from the GEMINI 1 study. Gastroenterology 2014;146(5 Suppl 1):S590.

* Feagan BG, Rutgeerts P, Sands BE, Hanauer S, Colombel JF, Sandborn WJ, et al. Vedolizumab as induction and maintenance therapy for ulcerative colitis. New England Journal of Medicine 2013; Vol. 369:699-710.

Feagan BG, Rutgeerts PJ, Sands BE, Colombel J, Sandborn

Placebo response and remission rates in randomised trials of induction and maintenance therapy for ulcerative colitis (Review)

Copyright () 2017 The Cochrane Collaboration. Published by John Wiley \& Sons, Ltd. 
WJ, Hanauer SB, et al. Induction therapy for ulcerative colitis: Results of GEMINI I, a randomized, placebocontrolled, double-blind, multicenter phase 3 trial. Gastroenterology 2012;142(5 Suppl 1):S160-1.

Feagan BG, Sandborn W, Smyth MD, Sankoh S, Parikh A, Fox I. Effects of continued vedolizumab therapy for ulcerative colitis in week 6 induction therapy nonresponders. Gastroenterology 2014;146(5 Suppl 1):S590.

Parikh A. Efficacy of vedolizumab in ulcerative colitis by prior treatment failure in gemini $\mathrm{i}$, a randomized, placebocontrolled, double-blind, multicenter trial. Inflammatory Bowel Diseases 2012;18:S26.

Rosario M, Fox I, Milch C, Parikh A, Feagan B, Sandborn W, et al. Pharmacokinetic/pharmacodynamic relationship and immunogenicity of vedolizumab in adults with inflammatory bowel disease: Additional results from GEMINI 1 and 2. Inflammatory Bowel Diseases 2013;19: S80.

Rosario M, French J, Dirks N, Milton A, Fox I, Gastonguay $\mathrm{M}$. Exposure response relationship during vedolizumab induction therapy in adults with ulcerative colitis. Journal of Crohn's and Colitis 2014;8:S270-1.

Rosario M, Wyant T, Milch C, Parikh A, Feagan B, Sandborn WJ, et al. Pharmacokinetic and pharmacodynamic relationship and immunogenicity of vedolizumab in adults with inflammatory bowel disease: Additional results from the GEMINI 1 and 2 studies. Journal of Crohn's and Colitis 2014;8:S42-3.

Sandborn W, Sands B, Rutgeerts P, Sankoh S, Rosario M, Milch C, et al. Sustained therapeutic benefit of vedolizumab throughout 1 year in ulcerative colitis in GEMINI I, a randomized, placebo-controlled, double-blind, multicenter trial. Journal of Crohn's and Colitis 2013;7:S138-9.

Sands B, Hanauer S, Colombel JF, Danese S, Abreu M, Ahuja V, et al. Reductions in corticosteroid use in patients with ulcerative colitis or crohn's disease treated with vedolizumab. American Journal of Gastroenterology 2013; 108:S503.

Hanauer 2000 \{published data only\}

Hanauer S, Good LI, Goodman MW, Pizinger RJ, Strum WB, Lyss C, et al. Long-term use of mesalamine (Rowasa) suppositories in remission maintenance of ulcerative proctitis. American Journal of Gastroenterology 2000; Vol. 95:1749-54

\section{Jiang 2015 \{published data only\}}

Jiang XL, Cui HF, Gao J, Fan H. Low-dose Infliximab for induction and maintenance treatment in Chinese patients with moderate to severe active ulcerative colitis. Journal of Clinical Gastroenterology 2015;49(7):582-8.

Kamm 2007 \{published data only\}

Kamm MA, Sandborn WJ, Gassull M, Schreiber

S, Jackowski L, Butler T, et al. Once-daily, highconcentration MMX mesalamine in active ulcerative colitis. Gastroeneterology 2007; Vol. 132:66-75.

Leiper 2011 \{published data only\}

Leiper K, Martin K, Ellis A, Subramanian S, Watson AJ, Christmas SE, et al. Randomised placebo-controlled trial of rituximab (anti-CD20) in active ulcerative colitis. Gut 2011; Vol. 60:1520-6.

\section{Lewis 2008 \{published data only\}}

Lewis JD, Lichtenstein GR, Deren JJ, Sands BE, Hanauer SB, Katz JA, et al. Rosiglitazone for active ulcerative colitis: a randomized placebo-controlled trial. Gastroenterology 2008;134:688-95.

Lichtenstein 2007 \{published data only\} Lichtenstein GR, Kamm MA, Boddu P, Gubergrits N, Lyne A, Butler T, et al. Effect of once- or twice-daily MMX mesalamine (SPD476) for the induction of remission of mild to moderately active ulcerative colitis. Clinical Gastroenterology and Hepatology 2007; Vol. 5:95-102.

Lichtenstein 2010 \{published data only\} Lichtenstein GR, Gordon GL, Zakko S, Murthy U, Sedghi $S$, Pruitt R, et al. Clinical trial: once-daily mesalamine granules for maintenance of remission of ulcerative colitis - a 6-month placebo-controlled trial. Alimentary Pharmacology and Therapeutics 2010; Vol. 32:990-9.

Marteau 2005 \{published data only\}

Marteau P, Probert CS, Lindgren S, Gassul M, Tan TG, Dignass A, et al. Combined oral and enema treatment with Pentasa (mesalazine) is superior to oral therapy alone in patients with extensive mild/moderate active ulcerative colitis: a randomised, double blind, placebo controlled study. Gut 2005; Vol. 54:960-5.

\section{Mayer 2014 \{published data only\}}

* Mayer L, Sandborn WJ, Stepanov Y, Geboes K, Hardi R, Yellin M, et al. Anti-IP-10 antibody (BMS-936557) for ulcerative colitis: a phase II randomised study. Gut 2014; 63:442-50.

Sandborn WJ, Colombel JF, Ghosh S, Sands BE, Xu LA, Luo, A. Phase IIB, randomized, placebo-controlled evaluation of the efficacy and safety of induction therapy with eldelumab (anti-IP-10 antibody; BMS-936557) in patients with active ulcerative colitis. Gastroenterology 2014; 1:S-150.

Sandborn WJ, Rutgeerts PJ, Colombel JF, Ghosh S, Petryka R, Sands BE, et al. Phase IIa, randomized, placebo-controlled evaluation of the efficacy and safety of induction therapy with eldelumab (anti-IP-10 antibody; BMS-936557) in patients with active crohn's disease. Gastroenterology 2015;1:S162-3.

Nikolaus 2003 \{published data only\}

Nikolaus S, Rutgeerts P, Fedorak R, Steinhart AH, Wild GE, Theuer $\mathrm{D}$, et al. Interferon beta-1a in ulcerative colitis: A placebo controlled, randomised, dose escalating study. Gut 2003;52:1286-90.

Ogata 2006 \{published data only\} Ogata H, Matsui T, Nakamura M, Iida M, Takazoe M, Suzuki $Y$, et al. A randomised dose finding study of oral tacrolimus (FK506) therapy in refractory ulcerative colitis. Gut 2006;55:1255-62.

\section{Ogata 2012 \{published data only\}}

Ogata H, Kato J, Hirai F, Hida N, Matsui T, Matsumoto T, et al. Double-blind, placebo-controlled trial of oral 
tacrolimus (FK506) in the management of hospitalized patients with steroid-refractory ulcerative colitis. Inflammatory Bowel Diseases 2012; Vol. 18:803-8.

\section{Oren 1996 \{published data only\}}

Oren R, Arber N, Odes S, Moshkowitz M, Keter D, Pomeranz I, et al. Methotrexate in chronic active ulcerative colitis: a double-blind, randomized, Israeli multicenter trial. Gastroenterology 1996; Vol. 110:1416-21.

Probert 2003 \{published data only\}

Probert CS, Hearing SD, Schreiber S, Kuhbacher T, Ghosh $\mathrm{S}$, Arnott I D, et al. Infliximab in moderately severe glucocorticoid resistant ulcerative colitis: a randomised controlled trial. Gut 2003;52:998-1002.

Reinisch 2011 \{published data only\}

Reinisch W, Sandborn WJ, Hommes DW, D'Haens G, Hanauer S, Schreiber S, et al. Adalimumab for induction of clinical remission in moderately to severely active ulcerative colitis: results of a randomised controlled trial. Gut 2011; Vol. 60:780-7.

Reinisch 2015 \{published data only\} Reinisch W, Panes J, Khurana S, Toth G, Hua F, Comer G, et al. Anrukinzumab, an anti-interleukin 13 monoclonal antibody, in active UC: efficacy and safety from a phase IIa randomised multicentre study. Gut 2015;64(6):894-900.

Rubin 2015 \{published data only\}

David R, Russell C, William S, Gary L, Jeffrey A, Robert $\mathrm{R}$, et al. Budesonide MMX $9 \mathrm{mg}$ for inducing remission in patients with mild-to-moderate ulcerative colitis not adequately controlled with oral 5-asas. Inflammatory Bowel Diseases 2014;20:S1.

* Rubin DT, Cohen RD, Sandborn WJ, Lichtenstein GR, Axler J, Riddell R, et al. Budesonide MMX 9 mg for inducing remission in patients with Mild-to-Moderate ulcerative colitis not adequately controlled with oral 5ASAs. Journal of Crohn's and Colitis 2015;9:S7.

Rutgeerts 2005a \{published data only\}

* Rutgeerts P, Sandborn WJ, Feagan BG, Reinisch W, Olson A, Johanns J, et al. Infliximab for induction and maintenance therapy for ulcerative colitis. New England Journal of Medicine 2005; Vol. 353:2462-76.

Rutgeerts 2005b \{published data only\}

* Rutgeerts P, Sandborn WJ, Feagan BG, Reinisch W, Olson A, Johanns J, et al. Infliximab for induction and maintenance therapy for ulcerative colitis. New England Journal of Medicine 2005; Vol. 353:2462-76.

Rutgeerts 2013a \{published data only\}

Rutgeerts PJ, Fedorak RN, Hommes DW, Sturm A, Baumgart DC, Bressler B, et al. A randomised phase I study of etrolizumab (rhuMAb beta7) in moderate to severe ulcerative colitis. Gut 2013; Vol. 62:1122-30.

Rutgeerts 2013b \{published data only\}

Rutgeerts PJ, Fedorak RN, Hommes DW, Sturm A, Baumgart DC, Bressler B, et al. A randomised phase I study of etrolizumab (rhuMAb beta7) in moderate to severe ulcerative colitis. Gut 2013; Vol. 62:1122-30.

\section{Rutgeerts 2015 \{published data only\}}

Rutgeerts P, Feagan BG, Marano CW, Padgett L, Strauss $\mathrm{R}$, Johanns J, et al. Randomised clinical trial: a placebocontrolled study of intravenous golimumab induction therapy for ulcerative colitis. Alimentary Pharmacology \& Therapeutics 2015;42(5):504-14.

Sandborn 1994 \{published data only\} Sandborn WJ, Tremaine WJ, Schroeder KW, Batts KP, Lawson GM, Steiner BL, et al. A placebo-controlled trial of cyclosporine enemas for mildly to moderately active leftsided ulcerative colitis. Gastroenterology 1994; Vol. 106: 1429-35.

\section{Sandborn 2003 \{published data only\}}

Sandborn WJ, Sands BE, Wolf DC, Valentine JF, Safdi M, Katz $S$, et al. Repifermin (keratinocyte growth factor-2) for the treatment of active ulcerative colitis: a randomized, double-blind, placebo-controlled, dose-escalation trial. Alimentary Pharmacology \& Therapeutics 2003;17:1355-64.

Sandborn 2012a \{published data only\} Ghosh S, Wolf D, Sandborn W, Colombel JF, Lazar A, Eichner $S$, et al. Sustained efficacy in patients with ulcerative colitis treated with adalimumab: results from ULTRA 2. Journal of Crohn's and Colitis 2013;7:S238. Mostafa NM, Eckert D, Pradhan RS, Mensing S, Robinson A, Sandborn W, et al. Exposure-efficacy relationship (ER) for adalimumab during induction phase of treatment of adult patients with moderate to severe ulcerative colitis. Gastroenterology 2013;1:S225-6.

Sandborn W, Van Assche G, Reinisch W, Colombel JF, D'Haens G, Wolf D, et al. Induction and maintenance of clinical remission by adalimumab in patients with moderate-to-severe ulcerative colitis. Inflammatory Bowel Diseases 2011;17:S3-4.

Sandborn WJ, D'Haens GR, Colombel JF, Van Assche GA, Wolf DC, Kron M, et al. One-year response and remission rates in ulcerative colitis patients with week 8 response to adalimumab: subanalysis of ULTRA 2. Gastroenterology 2012;1:S565.

* Sandborn WJ, van Assche G, Reinisch W, Colombel JF, D'Haens G, Wolf D C, et al. Adalimumab induces and maintains clinical remission in patients with moderate-tosevere ulcerative colitis. Gastroenterology 2012;142:257-65. Van Assche G, Wolf D, D’Haens G, Sandborn W, Colombel JF, Lazar A, et al. Reduced steroid usage in ulcerative colitis patients with week 8 response to adalimumab: subanalysis of ULTRA 2. Inflammatory Bowel Diseases 2012;18:S21-2.

Sandborn 2012b \{published data only\}

Sandborn WJ, Travis S, Moro L, Jones R, Gautille T, Bagin R, et al. Once-daily budesonide MMX extendedrelease tablets induce remission in patients with mild to moderate ulcerative colitis: Results from the CORE i study. Gastroenterology 2012; Vol. 143:1218-26.

\section{Sandborn 2012c \{published data only\}}

Sandborn WJ, Ghosh S, Panes J, Vranic I, Su C, Rousell S, et al. Tofacitinib, an oral janus kinase inhibitor, in active 
ulcerative colitis. New England Journal of Medicine 2012; 367:616-24.

Sandborn 2012d \{published data only\}

Sandborn WJ, Colombel JF, Sands BE, Rutgeerts P, Targan SR, Panaccione R, et al. Abatacept for Crohn's disease and ulcerative colitis. Gastroenterology 2012; Vol. 143:62-9.

Sandborn 2013a (BUCF3001) \{published data only\} Sandborn W, Bosworth B, Zakko S, Gordon G, Rolleri $\mathrm{R}, \mathrm{Yu}$ J, et al. Budesonide foam for inducing remission in active mild-to-moderate ulcerative proctitis or ulcerative proctosigmoiditis: Results of two randomized, placebocontrolled trials. American Journal of Gastroenterology 2013; 108:S542.

Sandborn 2013b (BUCF3002) \{published data only\} Sandborn W, Bosworth B, Zakko S, Gordon G, Rolleri $\mathrm{R}, \mathrm{Yu}$ J, et al. Efficacy and safety of budesonide foam for inducing remission in mildly to moderately active ulcerative proctitis or ulcerative proctosigmoiditis. Inflammatory Bowel Diseases 2013;19:S83.

\section{Sandborn 2014a \{published data only\}}

Sandborn WJ, Feagan BG, Marano C, Zhang H, Strauss $\mathrm{R}$, Johanns J, et al. Subcutaneous golimumab maintains clinical response in patients with moderate-to-severe ulcerative colitis. Gastroenterology 2014;146:96-109.

\section{Sandborn 2014b \{published data only\}}

Sandborn WJ, Feagan BG, Marano C, Zhang H, Strauss R, Johanns J, et al. Subcutaneous golimumab induces clinical response and remission in patients with moderate-to-severe ulcerative colitis. Gastroenterology 2014;146:85-95.

\section{Sandborn 2015 \{published data only\}}

* Sandborn WJ, Colombel JF, Ghosh S, Sands BE, Dryden G, Hébuterne X, et al. Eldelumab [Anti-IP-10] induction therapy for ulcerative colitis: A randomised, placebocontrolled, Phase $2 \mathrm{~b}$ study. Journal of Crohn's and Colitis 2016;E-pub ahead of print:1-11.

Sandborn WJ, Colombel JF, Ghosh S, Sands BE, Xu LA, Luo A. Phase IIB, randomized, placebo-controlled evaluation of the efficacy and safety of induction therapy with eldelumab (anti-IP-10 antibody; BMS-936557) in patients with active ulcerative colitis. Gastroenterology 2014; 146 (5 Suppl 1):S-150.

\section{Sands 2012 \{published data only\}}

Sands BE, Sandborn WJ, Creed TJ, Dayan CM, Dhanda $\mathrm{AD}$, Assche GA, et al. Basiliximab does not increase efficacy of corticosteroids in patients with steroid-refractory ulcerative colitis. Gastroenterology 2012; Vol. 143: 356-64.e1.

\section{Scherl 2009 \{published data only\}}

Bosworth BP, Pruitt RE, Gordon GL, Lamet M, Shaw AL, Huang $S$, et al. Balsalazide tablets $3.3 \mathrm{~g}$ twice daily improves signs and symptoms of mild-to-moderate ulcerative colitis. Gastroenterology 2008;134:A-495.

* Scherl EJ, Pruitt R, Gordon GL, Lamet M, Shaw A, Huang S, et al. Safety and efficacy of a new $3.3 \mathrm{~g}$ b.i.d. tablet formulation in patients with mild-to-moderatelyactive ulcerative colitis: a multicenter, randomized, double- blind, placebo-controlled study. American Journal of Gastroenterology 2009; Vol. 104:1452-9.

Schreiber 2007 \{published data only\}

Schreiber S, Keshavarzian A, Isaacs KL, Schollenberger J, Guzman JP, Orlandi C, et al. A randomized, placebocontrolled, phase II study of tetomilast in active ulcerative colitis. Gastroenterology 2007; Vol. 132:76-86.

Schroeder 1987 \{published data only\}

Schroeder KW, Tremaine WJ, Ilstrup DM. Coated oral 5-aminosalicylic acid therapy for mildly to moderately active ulcerative colitis. A randomized study. New England Journal of Medicine 1987; Vol. 317:1625-9.

Sninsky 1991 \{published data only\} Sninsky CA, Cort DH, Shanahan F, Powers BJ, Sessions JT, Pruitt RE, et al. Oral mesalamine (Asacol) for mildly to moderately active ulcerative colitis. A multicenter study. Annals of Internal Medicine 1991; Vol. 115:350-5.

Steinhart 1996 \{published data only\} Steinhart AH, Hiruki T, Brzezinski A, Baker JP. Treatment of left-sided ulcerative colitis with butyrate enemas: a controlled trial. Alimentary Pharmacology and Therapeutics 1996; Vol. 10:729-36.

Sutherland 1987a \{published data only\}

Sutherland LR, Martin F, Greer S. 5-Aminosalicylic acid enema in the treatment of distal ulcerative colitis, proctosigmoiditis, and proctitis. Gastroenterology 1987;92: 1894-8.

Sutherland 1987b \{published data only\}

Sutherland LR, Martin F. 5-Aminosalicylic acid enemas in treatment of distal ulcerative colitis and proctitis in Canada. Digestive Diseases and Sciences 1987; Vol. 32:64s-6s.

Sutherland 1990 \{published data only\} Sutherland LR, Robinson M, Onstad G, Peppercorn M, Greenberger N, Goodman M, et al. A double-blind, placebo controlled, multicentre study of the efficacy and safety of 5-aminosalicylic acid tablets in the treatment of ulcerative colitis. Canadian Journal of Gastroenterology 1990; Vol. 4:463-7.

\section{Suzuki 2014 \{published data only\}}

Suzuki Y, Motoya S, Hanai H, Matsumoto T, Hibi T, Robinson A, et al. Efficacy and safety of adalimumab in Japanese patients with moderately to severely active ulcerative colitis. Journal of Gastroenterology 2014;49(2): 283-94.

Suzuki 2015 \{published data only\} Suzuki Y, Motoya S, Hirai F, Ogata H, Ito H, Sato N, et al. Infliximab therapy for Japanese patients with ulcerative colitis: Efficacy, safety, and association between serum infliximab levels and early response in a randomized, double-blind, placebo-controlled study. Journal of Crohn's and Colitis 2015;9:S372-3.

Travis 2014 \{published data only\} Travis SPL, Danese S, Kupcinskas L, Alexeeva O, D’Haens G, Gibson PR, et al. Once-daily budesonide MMX in active, mild-to-moderate ulcerative colitis: Results from the randomised CORE II study. Gut 2014;63:433-41. 
Van Assche 2006 \{published data only\}

Assche G, Sandborn WJ, Feagan BG, Salzberg BA, Silvers

D, Monroe PS, et al. Daclizumab, a humanised monoclonal antibody to the interleukin 2 receptor $(\mathrm{CD} 25)$, for the treatment of moderately to severely active ulcerative colitis: a randomised, double blind, placebo controlled, dose ranging trial. Gut 2006; Vol. 55:1568-74.

\section{Vermeire 2011 \{published data only\}}

Vermeire S, Ghosh S, Panes J, Dahlerup JF, Luegering A, Sirotiakova J, et al. The mucosal addressin cell adhesion molecule antibody PF-00547,659 in ulcerative colitis: A randomised study. Gut 2011;60:1068-75.

Vermeire 2014 \{published data only\}

Vermeire S, O’Byrne S, Keir M, Williams M, Lu TT,

Mansfield JC, et al. Etrolizumab as induction therapy for ulcerative colitis: A randomised, controlled, phase 2 trial. Lancet 2014;384(9940):309-18.

Watanabe 2013 \{published data only\}

Watanabe M, Nishino H, Sameshima Y, Ota A, Nakamura $S$, Hibi T. Randomised clinical trial: Evaluation of the efficacy of mesalazine (mesalamine) suppositories in patients with ulcerative colitis and active rectal inflammation - A placebo-controlled study. Alimentary Pharmacology and Therapeutics 2013; Vol. 38:264-73.

Williams 1987 \{published data only\} Williams CN, Haber G, Aquino JA. Double-blind, placebocontrolled evaluation of 5-ASA suppositories in active distal proctitis and measurement of extent of spread using $99 \mathrm{mTc}$ labeled 5-ASA suppositories. Digestive Diseases and Science 1987; Vol. 32:71s-5s.

Yoshimura 2015 \{published data only\}

Watanabe M, Yoshimura N, Motoya S, Tominaga K, Iwakiri R, Watanabe K, et al. AJM300, an oral A4 integrin antagonist, for active ulcerative colitis: A multicenter, randomized, double-blind, placebo-controlled phase $2 \mathrm{a}$ study. Gastrointestinal Endoscopy 2014;1:AB294.

Watanabe M, Yoshimura N, Motoya S, Tominaga K, Iwakiri $\mathrm{R}$, Watanabe K, et al. AJM300, an oral alpha4 integrin antagonist, for active ulcerative colitis: A multicenter, randomized, double-blind, placebo-controlled phase $2 \mathrm{~A}$ study. Gastroenterology 2014;1:S-82.

* Yoshimura N, Watanabe M, Motoya S, Tominaga K, Matsuoka K, Iwakiri R, et al. Safety and efficacy of AJM300, an oral antagonist of a4I integrin, in induction therapy for patients with active ulcerative colitis. Gastroenterology 2015; 149:1775-83.

\section{References to studies excluded from this review}

Angus 1992 \{published data only\}

Angus P, Snook JA, Reid M, Jewell DP. Oral fluticasone propionate in active distal ulcerative colitis. Gut 1992;33: $711-4$.

Ardizzone 1999 \{published data only\}

Ardizzone S, Petrillo M, Imbesi V, Cerutti R, Bollani S, Bianchi Porro G. Is maintenance therapy always necessary for patients with ulcerative colitis in remission?. Alimentary Pharmacology \& Therapeutics 1999;13:373-9.

Armuzzi 2014 \{published data only\}

Armuzzi A, Felice C. Etrolizumab in moderate-to-severe ulcerative colitis. Lancet 2014;384(9940):285-6.

Bayles 1995 \{published data only\}

Bayles T, Sninsky C. Budesonide enema is an effective alternative to hydrocortisone enema in active distal ulcerative colitis. Gastroenterology 1995;108(4):A778.

Biddle 1988 \{published data only\}

Biddle WL, Greenberger NJ, Swan JT, McPhee MS, Miner Jr PB. 5-Aminosalicylic acid enemas: effective agent in maintaining remission in left-sided ulcerative colitis. Gastroenterology 1988;94(4):1075-9.

Bossa 2013 \{published data only\}

Bossa F, Annese V, Valvano MR, Latiano A, Martino G, Rossi L, et al. Erythrocytes-mediated delivery of dexamethasone 21-phosphate in steroid-dependent ulcerative colitis: A randomized, double-blind shamcontrolled study. Inflammatory Bowel Diseases 2013; Vol. 19, issue 9:1872-9.

Buckell 1978 \{published data only\} Buckell NA, Gould SR, Day DW, Lennard-Jones JE, Edwards AM. Controlled trial of disodium cromoglycate in chronic persistent ulcerative colitis. Gut 1978; Vol. 19, issue 12:1140-3.

Burke 1990 \{published data only\}

Burke DA, Axon AT, Clayden SA, Dixon MF, Johnston D, Lacey RW. The efficacy of tobramycin in the treatment of ulcerative colitis. Alimentary Pharmacology \& Therapeutics 1990;4(2):123-9.

\section{Calring 1994 \{published data only\}} Calring L, Kagevi I, Anker-Hansén O, Hallerbäck B, Svedberg LE, Wallin T, et al. Sucralfate enema in the treatment of ulcerative proctitis: A randomized placebo controlled double blind study. Gut 1994; Vol. 35, issue Supp 4:A119.

\section{Campieri 1978 \{published data only\}} Campieri M, Lanfranchi G A, Bazzocehi G, Brignola C, Corazza G, Cortini C, et al. Salicylate other than 5aminosalicylic acid ineffective in ulcerative colitis. Lancet 1978; Vol. 2, issue 8097:993.

\section{Campieri 1981 \{published data only\}} Campieri M, Lanfranchi GA, Franzin G. Effect of 5aminosalicylic acid in local treatment of active ulcerative colitis. A double blind multicentre trial. Italian Journal of Gastroenterology 1981;13(4):278-9.

\section{Campieri 1987 \{published data only\}}

Campieri M, Gionchetti P, Belluzzi A, Brignola C, Migaldi M, Tabanelli G M, et al. Efficacy of 5-aminosalicylic acid enemas versus hydrocortisone enemas in ulcerative colitis. Digestive Diseases \& Sciences 1987;32(Suppl 12):67S-70S.

\section{Campieri 1988 \{published data only\}}

Campieri M, Gionchetti P, Belluzzi A. 5-Aminosalicylic Acid, Sucralfate and Placebo Enemas in the Treatment of

Placebo response and remission rates in randomised trials of induction and maintenance therapy for ulcerative colitis (Review)

Copyright (C) 2017 The Cochrane Collaboration. Published by John Wiley \& Sons, Ltd. 
Distal Ulcerative Colitis (UC). Gastroenterology 1988;94: A58.

Campieri 1989 \{published data only\}

Campieri M, Brunetti G, Miglioli M, Barbara L, Russo A, Aprile G, et al. Topical treatment with 5-ASA suppositories in distal ulcerative colitis. A randomized double blind placebo controlled study with Asacol suppositories. An Italian co-operative study group. Italian Journal of Gastroenterology 1989; Vol. 21:15-6.

Campieri 1990a \{published data only\}

Campieri M, Gionchetti P, Belluzzi A, Brignola C, Tampieri $\mathrm{M}$, Iannone $\mathrm{P}$, et al. Topical treatment with 5-aminosalicylic in distal ulcerative colitis by using a new suppository preparation. A double-blind placebo controlled trial. International Journal of Colorectal Disease 1990; Vol. 5, issue 2:79-81.

Campieri 1990b \{published data only\}

Campieri M, Franchis R, Bianchi Porro G, Ranzi T, Brunetti G, Barbara L. Mesalazine (5-aminosalicylic acid) suppositories in the treatment of ulcerative proctitis or distal proctosigmoiditis. A randomized controlled trial. Scandanavian Journal of Gastroenterology 1990; Vol. 25, issue 7:663-8.

Campieri 1991a \{published data only\}

Campieri M, Gionchetti P, Belluzzi A, Brignola C, Tampieri M, Iannone P, et al. Sucralfate, 5-aminosalicylic acid and placebo enemas in the treatment of distal ulcerative colitis. European Journal of Gastroenterology and Hepatology 1991;3: $41-4$.

Campieri 1991b \{published data only\}

Campieri M, Bianchi P, Bianchi P G, d'Albasio G, Capurso L, Cottone M, et al. Comparison of 5-ASA (ASACOL ${ }^{\circledR}$ ) enema and foam in the treatment of distal ulcerative colitis. Italian Journal of Gastroenterology 1991; Vol. 23:510-1.

D’Albasio 1995 \{published data only\}

D’Albasio G, Pacini F, Camarri E, Milla M, Ferrero S, Biagini $M$, et al. Combined therapy with 5-aminosalicylic acid tablets and enemas for maintaining remission in ulcerative colitis: results at 12 months. Gastroenterology 1995;108(4):A805.

D’Albasio 1997 \{published data only\}

D’Albasio G, Pacini F, Camarri E, Messori A, Trallori G, Bonanomi A G, et al. Combined therapy with 5aminosalicylic acid tablets and enemas for maintaining remission in ulcerative colitis: a randomized double-blind study. American Journal of Gastroenterology 1997; Vol. 92, issue 7:1143-7.

D'Albasio 1998 \{published data only\} d'Albasio G, Paoluzi P, Campieri M, Bianchi Porro G, Pera A, Prantera C, et al. Maintenance treatment of ulcerative proctitis with mesalazine suppositories: a double-blind placebo-controlled trial. The Italian IBD Study Group. American Journal of Gastroenterology 1998;93(5):799-803.

D'Arienzo 1990 \{published data only\}

D’Arienzo A, Panarese A, D’Armiento F P, Lancia C, Quattrone P, Giannattasio F, et al. 5-Aminosalicylic acid suppositories in the maintenance of remission in idiopathic proctitis or proctosigmoiditis: a double-blind placebo-controlled clinical trial. American Journal of Gastroenterology 1990; Vol. 85, issue 9:1079-82.

D’Haens 2010 \{published data only\}

D'Haens G R, Kovacs A, Vergauwe P, Nagy F, Molnar T, Bouhnik Y, et al. Clinical trial: Preliminary efficacy and safety study of a new Budesonide-MMX $9 \mathrm{mg}$ extendedrelease tablets in patients with active left-sided ulcerative colitis. Journal of Crohn's \& colitis 2010;4:153-60.

Danielsson 1992 \{published data only\} Danielsson A, Lofberg R, Persson T, Salde L, Schioler $\mathrm{R}$, Suhr C, et al. A steroid enema, budesonide, lacking systemic effects for the treatment of distal ulcerative colitis or proctitis. Scandinavian Journal of Gastroenterology 1992; 27(1):9-12.

Da Silva Sanchez 2014 \{published data only\} Da Silva Sanchez S, Palmen M, Streck P, Inglis S. Pooled clinical trial analysis of MMX mesalazine safety: Focus on $4.8 \mathrm{~g} / \mathrm{d}$ long-term exposure. Journal of Crohn's and Colitis 2014;8(Supp 1):S230.

Davies 1977 \{published data only\} Davies PS, Rhodes J, Heatley RV, Owen E. Metronidazole in the treatment of chronic proctitis: a controlled trial. Gut 1977; Vol. 18, issue 8:680-1.

Dew 1982 \{published data only\} Dew MJ, Hughes P, Harries AD, Williams G, Evans BK, Rhodes J. Maintenance of remission in ulcerative colitis with oral preparation of 5-aminosalicylic acid. BMJ 1982; Vol. 285, issue 6384:1012.

Dick 1964 \{published data only\} Dick AP, Grayson MJ, Carpenter RG, Petrie A. Controlled trial of sulphasalazine in the treatment of ulcerative colitis. Gut 1964; Vol. 5, issue 5:437-42.

Dickinson 1985 \{published data only\} Dickinson RJ, O'Connor HJ, Pinder I, Hamilton I, Johnston D, Axon AT. Double blind controlled trial of oral vancomycin as adjunctive treatment in acute exacerbations of idiopathic colitis. Gut 1985; Vol. 26, issue 12:1380-4.

Dissanayake 1973 \{published data only\} Dissanayake AS, Truelove SC. A controlled therapeutic trial of long-term maintenance treatment of ulcerative colitis with sulphazalazine (Salazopyrin). Gut 1973;14(12):923-6.

Feagan 2012 \{published data only\}

Feagan B, Sandborn W, Lazar A, Thakkar R, Skup M, Yang $\mathrm{M}$, et al. Adalimumab induction dose reduces the risk of hospitalizations and colectomies in patients with ulcerative colitis during the first 8 weeks of therapy. American Journal of Gastroenterology 2012;107:S647.

Feurle 1989 \{published data only\} Feurle GE, Theuer D, Velasco S, Barry BA, Wördehoff D, Sommer A, et al. Olsalazine versus placebo in the treatment of mild to moderate ulcerative colitis: a randomised double blind trial. Gut 1989; Vol. 30, issue 10:1354-61. 
Fruehmorgen 1980 \{published data only\} Fruehmorgen P, Demling L. On the efficacy of readymade-up commercially available salicylazosulphapyridine enemas in the treatment of proctitis, proctosigmoiditis and ulcerative colitis involving rectum, sigmoid and descending colon. Hepato-Gastroenterology 1980;27(6):473-6.

Fruhmorgen 1981 \{published data only\}

Fruhmorgen P. The effectiveness of packaged salicylazosulfapyridine (Azulfidine)-enema in proctitis, proto-sigmoiditis and left-sided colitis [German]. Zeitschrift fur Gastroenterologie 1981;19:36-7.

Gandolfo 1987 \{published data only\}

Gandolfo J, Farthing M, Powers G. 4-Aminosalicyclic acid retention enemas in treatment of distal colitis. Digestive Diseases and Sciences 1987;32(7):700-4.

Ginsberg 1985 \{published data only\} Ginsberg AL, Steinberg WM, Nochomovitz LE. Deterioration of Left Sided Ulcerative Colitis After Withdrawl of Sulfasalazine. Gastroenterology 1985;88(5 Part 2):A1395.

Ginsberg 1988 \{published data only\} Ginsberg AL, Beck LS, McIntosh TM, Nochomovitz LE. Treatment of left-sided ulcerative colitis with 4aminosalicylic acid enemas. A double-blind, placebocontrolled trial. Annals of Internal Medicine 1988; Vol. 108:195-9.

Ginsberg 1992 \{published data only\} Ginsberg AL, Davis ND, Nochomovitz LE. Placebocontrolled trial of ulcerative colitis with oral 4-aminosalicylic acid. Gastroenterology 1992; Vol. 102:448-52.

Gionchetti 1999 \{published data only\} Gionchetti P, Rizzello F, Ferrieri A, Venturi A, Brignola C, Ferretti M, et al. Rifaximin in patients with moderate or severe ulcerative colitis refractory to steroid-treatment: a double-blind, placebo-controlled trial. Digestive Diseases and Sciences 1999; Vol. 44:1220-1.

Hanauer 1989 \{published data only\}

Hanauer SB, Kane SV, Guernsey B. Randomized Clinical Trial of Mesalamine (5-ASA) Enemas in Distal Ulcerative Colitis: A Dose-Ranging Placebo Controlled Study. Gastroenterology 1989;96(5 Part 2):A195.

Hanauer 1989a \{published data only\}

Hanauer SB, Schwartz J, Roufail W. Dose-Ranging Study of Oral Mesalamine Capsule (Pentasa) for Active Ulcerative Colitis. Gastroenterology 1989;96(5 Part 2):A195.

Hanauer 1990 \{published data only\}

Hanauer S, Beshears L, Wilkinson C. Induction of Remission in a Dose-Ranging Study of Oral Mesalamine Capsules (Pentasa). Gastroenterology 1990; Vol. 98, issue 5 Part 2:A174

Hanauer 1992 \{published data only\}

Hanauer S B, Lingamneni S, McPherson M, Beshears L. Placebo response in UC: analysis of a multi-center, doubleblind trial of controlled- release mesalamine (Pentasa). Gastroenterology 1992;102:A634.
Hanauer 1993 \{published data only\}

Hanauer S, Schwartz J, Robinson M, Roufail W, Arora S, Cello J, et al. Mesalamine capsules for treatment of active ulcerative colitis: results of a controlled trial. Pentasa Study Group. American Journal of Gastroenterology 1993;88: 1188-97.

Hanauer 1994 \{published data only\} Hanauer S, Powers B, Robinson M, Mayle J, Elson C, DeMicco $\mathrm{M}$, et al. Maintenance of remission of ulcerative colitis by mesalamine (Asacol) vs. placebo. Gastroenterology 1994;106:A696.

Hanauer 1996a \{published data only\} Hanauer SB. An oral preparation of mesalamine as long-term maintenance therapy for ulcerative colitis. A randomized, placebo-controlled trial. Annals of Internal Medicine 1996;124:204-11.

Hanauer 1996b \{published data only\} Hanauer SB, Barish C, Pambianco D, Sigmon R, Gannan R, Koval G, et al. A multi-center, double-blind, placebocontrolled, dose-ranging trial of olsalazine for mildmoderately active ulcerative colitis. Gastroenterology 1996; 110:A921.

Hanauer 1998 \{published data only\} Hanauer SB. Dose-ranging study of mesalamine (PENTASA) enemas in the treatment of acute ulcerative proctosigmoiditis: results of a multicentered placebocontrolled trial. The U.S. PENTASA Enema Study Group. Inflammatory Bowel Diseases 1998; Vol. 4:79-83.

Hanauer 1998a \{published data only\} Hanauer SB, Robinson M, Pruitt R, Lazenby AJ, Persson T, Nilsson LG, et al. Budesonide enema for the treatment of active, distal ulcerative colitis and proctitis: A dose-ranging study. Gastroenterology 1998;115:525-32.

Hanauer 2007 \{published data only\}

Hanauer S, Sandborn W, Lichtenstein G, Kamm M, Barrett $\mathrm{K}$, Joseph R. MMX mesalamine for providing remission of active mild-to-moderate ulcerative. Inflammatory Bowel Diseases 2007;13:663.

Hanauer 2009 \{published data only\} Hanauer SB, Lichtenstein GR, Kamm MA, Sandborn WJ, Lees $\mathrm{KH}$, Barrett $\mathrm{K}$, et al. MMX mesalamine for induction and maintenance therapy in mild-to-moderate ulcerative colitis. Gastroenterology and Hepatology 2009;5:494-500.

Hawkey 1994 \{published data only\} Hawkey C, Gassull M, Lauritsen K, Martin F, O'Morain C, Rask-Madsen J, et al. Efficacy of zileuton, a 5-lipoxygenase inhibitor, in the maintenance of remission in patients with ulcerative colitis. Gastroenterology 1994;106:A697.

Hawkey 1997 \{published data only\} Hawkey C J, Dube L M, Rountree L V, Linnen P J, Lancaster J F. A trial of zileuton versus mesalazine or placebo in the maintenance of remission of ulcerative colitis. Gastroenterology 1997;112:718-24.

Hawthorne 1992 \{published data only\} Hawthorne A B, Logan R F, Hawkey C J, Foster P N, Axon A T, Swarbrick E T, et al. Randomised controlled trial of

Placebo response and remission rates in randomised trials of induction and maintenance therapy for ulcerative colitis (Review) 
azathioprine withdrawal in ulcerative colitis. BMJ 1992; 305:20-2.

Hetzel 1985 \{published data only\}

Hetzel DJ, Bochner F, Imhoff DM. Azodisalicylate (ADS) in the Treatment of Ulcerative Colitis (UC): A Controlled Trial and Assessment of Drug Disposition. Gastroenterology 1985;88(5 Part 2):A1418.

Hetzel 1988 \{published data only\}

Hetzel DJ, Shearman DJ, Labrooy J, Bochner F, Imhoff DM, Gibson GE, et al. Olsalazine in the treatment of active ulcerative colitis: a placebo controlled clinical trial and assessment of drug disposition. Scandinavian Journal of Gastroenterology 1988;148:61-9.

Hollanders 1982 \{published data only\} Hollanders D, Thomson JM, Schofield PF. Tranexamic acid therapy in ulcerative colitis. Postgraduate Medical Journal 1982; Vol. 58:87-91.

Järnerot 2005 \{published data only\} Järnerot G, Hertervig E, Friis-Liby I, Blomquist L, Karlén $\mathrm{P}$, Grännö $\mathrm{C}$, et al. Infliximab as rescue therapy in severe to moderately severe ulcerative colitis: a randomized, placebo-controlled study. Gastroenterology 2005; Vol. 128: 1805-11.

\section{Jewell 1972 \{published data only\}}

Jewell DP, Truelove SC. Azathioprine in ulcerative colitis: an interim report on a controlled therapeutic trial. British Medical Journal 1972; Vol. 1:709-12.

Jewell 1974 \{published data only\}

Jewell DP, Truelove SC. Azathioprine in ulcerative colitis: final report on controlled therapeutic trial. British Medical Journal 1974;4:627-30.

\section{Kamm 2006 \{published data only\}}

Kamm M A, Schreiber S, Butler T, Barrett K, Stephenson $\mathrm{D}$, Joseph R E. Safety analysis of MMX mesalazine for the maintenance of remission of mild-to-moderate ulcerative colitis: results of a 4-month interim data analysis. Gut 2006;55(Suppl 5):126.

\section{Kamm 2008 \{published data only\}}

Kamm M A, Lichtenstein G R, Sandborn W J, Schreiber S, Lees K, Barrett K, et al. Randomised trial of once- or twicedaily MMX mesalazine for maintenance of remission in ulcerative colitis. Gut 2008; Vol. 57, issue 7:893-902.

Kamm 2009 \{published data only\}

Kamm M, Sandborn W, Lichtenstein G, Solomon D, Karlstadt R, Barrett K, et al. Induction of clinical and endoscopic remission in mild-to-moderate ulcerative colitis in patients treated with MMX mesalamine: Established versus newly diagnosed disease. Inflammatory Bowel Diseases 2009; 15:S34.

Kamm 2009a \{published data only\}

Kamm M A, Lichtenstein G R, Sandborn W J, Schreiber $\mathrm{S}$, Lees $\mathrm{K}$, Barrett $\mathrm{K}$, et al. Effect of extended MMX mesalamine therapy for acute, mild-to-moderate ulcerative colitis. Inflammatory Bowel Diseases 2009;15:1-8.
Karner 2014 \{published data only\}

Karner M, Kocjan A, Stein J, Schreiber S, Von Boyen G, Uebel P, et al. First multicenter study of modified release phosphatidylcholine LT-02 in ulcerative colitis: A randomized, placebo-controlled trial in mesalazinerefractory courses. American Journal of Gastroenterology 2014;109(7):1041-51.

\section{Kirk 1982 \{published data only\}}

Kirk AP, Lennard-Jones JE. Controlled trial of azathioprine in chronic ulcerative colitis. British Medical Journal 1982; Vol. 284:1291-2.

Kornbluth 1994 \{published data only\} Kornbluth A, Lichtiger S, Present D, Hanauer S. Long-term results of oral cyclosporin in patients with severe ulcerative colitis: a double-blind, randomized, multi-center trial. Gastroenterology 1994;106:A714.

Korzenik 2003 \{published data only\} Korzenik J, Miner Jr P, Stanton D, Isaacs K, Zimmerman E, Riff D, et al. Multicenter, randomized, double-blind, placebo-controlled trial of deligoparin (ultra low molecular weight heparin) for active ulcerative colitis. Gastroenterology 2003;124:A67.

\section{Kumana 1981 \{published data only\}}

Kumana C, Meghji M, Seaton T. Topical beclomethasone diproprionate for inflammatory bowel disease. Annals of the Royal College of Physicians and Surgeons of Canada 1981;14: No. 90 .

Lemann 1992 \{published data only\}

Lemann M. [4-ASA by oral administration in hemorrhagic rectocolitis: first controlled study]. Gastroenterologie Clinique et Biologique 1992;16:827-8.

Lennard-Jones 1962 \{published data only\} Lennard-Jones J E, Baron J H, Connell A M, Avery Jones F. A double blind controlled trial of prednisolone-21phosphate suppositories in the treatment of idiopathic proctitis. Gut 1962; Vol. 3:207.

Lennard-Jones 1965 \{published data only\} Lennard-Jones J, Misiewicz J J, Connell A M, Baron J $\mathrm{H}$, Jones F A. Prednfeone as maintenance treatment for ulcerative colitis in remission. Lancet 1965;1:188-9.

Lewis 2001 \{published data only\} Lewis J D, Lichtenstein G R, Stein R B, Deren J J, Judge T A, Fogt F, et al. An open-label trial of the PPAR ligand rosiglitazone for active ulcerative colitis. American Journal of Gastroenterology 2001;96:3323-8.

Lewis 2013 \{published data only\} Lewis J, Ghosh S, Sandborn W, Van Assche G, D’Haens G, Lazar A, et al. Rates of "patient-defined" remission with adalimumab in patients with ulcerative colitis: Subanalysis of ULTRA 1 and ULTRA 2. Journal of Crohn's and Colitis 2013;7:S166.

Lichtenstein 2007a \{published data only\} Lichtenstein G, Kamm M, Sandborn W, Gassull M, Schreiber S, Jackowski L, et al. MMX mesalamine induces remission of mild-to-moderate ulcerative colitis in patients 
who have changed directly from other oral 5-ASA therapies and in those who have not previously received or who have discontinued 5-ASA: A combined analysis of two phase III studies. Inflamm Bowel Dis 2007;13:667.

Lichtenstein 2008 \{published data only\}

Lichtenstein G R, Kamm M A, Sandborn W J, Lyne A, Joseph R E. MMX mesalazine for the induction of remission of mild-to-moderately active ulcerative colitis: efficacy and tolerability in specific patient subpopulations. Alimentary Pharmacology and Therapeutics 2008; Vol. 27:1094-102.

Lichtenstein 2009a \{published data only\} Lichtenstein G R, Diamond R H, Wagner C L, Fasanmade A A, Olson A D, Marano C W, et al. Clinical trial: benefits and risks of immunomodulators and maintenance infliximab for IBD-subgroup analyses across four randomized trials. Alimentary Pharmacology and Therapeutics 2009; Vol. 30, issue 3:210-26.

Lichtenstein 2009b \{published data only\} Lichtenstein G, Sandborn W, Kamm M, Solomon D, Karlstadt R, Barrett K, et al. Induction of mucosal healing in mild-to-moderate ulcerative colitis in patients treated with MMX mesalamine: Established versus newly diagnosed disease. Inflammatory Bowel Diseases 2009;15:S35.

Lichtenstein 2010a \{published data only\} Lichtenstein G, Gordon G L, Zakko S, Murthy U, Sedghi $\mathrm{S}$, Pruitt R E, et al. Once-daily mesalamine granules $(1.5 \mathrm{~g})$ for maintenance of remission from ulcerative colitis: A subgroup analysis. Gastroenterology 2010;1):S165.

Lichtenstein 2012 \{published data only\} Lichtenstein G R, Zakko S, Gordon G L, Murthy U, Sedghi S, Pruitt R, et al. Mesalazine granules $1.5 \mathrm{~g}$ oncedaily maintain remission in patients with ulcerative colitis who switch from other 5-ASA formulations: a pooled analysis from two randomised controlled trials. Alimentary Pharmacology and Therapeutics 2012; Vol. 36, issue 2: 126-34.

Lichtenstein 2013a \{published data only\} Lichtenstein G R, Sandborn W, Huang M, Hardiman Y, Bagin R, Yeung P, et al. Budesonide MMX 9 mg induces remission in mild-to-moderately active UC patients regardless of prior history of 5-ASA therapy. Gastroenterology 2013;1):S234.

Lichtenstein 2013b \{published data only\} Lichtenstein G, Sandborn W, Huang M, Hardiman Y, Bagin R, Yeung P, et al. Budesonide MMX versus placebo in patients with active, mild-to-moderate ulcerative colitis who were 5-ASA naive or previously treated with 5-ASA. Inflammatory Bowel Diseases 2013;19:S83.

Lichtiger 1994 \{published data only\} Lichtiger S, Present D H, Kornbluth A, Gelernt I, Bauer J, Galler G, et al. Cyclosporine in severe ulcerative colitis refractory to steroid therapy. New England Journal of Medicine 1994; Vol. 330:1841-5.

Lindgren 1997 \{published data only\}

Lindgren S, Suhr O, Persson T, Pantzar N. Treatment of active distal ulcerative colitis (UC) and maintenance of remission with Entocort ${ }^{\circledR}$ enema: A randomised controlled dosage study. Gut 1997; Vol. 41 Suppl 3:A223.

Lindgren 2001 \{published data only\}

Lindgren Stefan, Suhr Ole B, Persson Tore. BUDESONIDE ENEMA ONCE DAILY SHOWS SIMILAR EFFICACY

AS BUDESONIDE ENEMA TWICE DAILY FOR TREATMENT OF ACTIVE DISTAL ULCERATIVE COLITIS. Gastroenterology 2001;120:A-748.

Lindgren 2002 \{published data only\} Lindgren S, Löfberg R, Bergholm L, Hellblom M, Carling L, Ung K A, et al. Effect of budesonide enema on remission and relapse rate in distal ulcerative colitis and proctitis. Scandanavian Journal of Gastroenterology 2002; Vol. 37: 705-10.

Lopes 1988 \{published data only\} Lopes Pontes E, Lemme E M O, Porto J A F, Zaltman C, Da Silveira V L A. 5-Aminosalicylic acid (5-ASA) enemas in the treatment of acute ulcerative colitis: A controlled study. [Portuguese]. Folha Medica 1988;96:231-4.

Mallow 2013 \{published data only\} Mallow P, Rizzo J, Queener M, Gathany T, Lofland J. Comparative efficacy of adalimumab, golimumab, and infliximab in the treatment of patients with ulcerative colitis: An induction analysis. American Journal of Gastroenterology 2013;108:S514.

Marakhovski 1999 \{published data only\} Marakhovski YKh, Lakovich F S, Prozetski V A, Mrakhovski K I, Azemsha E I, Domorod A I, et al. Comparative, randomised study of the efficacy and tolerance of bosmofalk vs Placebo in patients with active ulcerative colitis. Gastroenterology 1999; Vol. 45:A132.

Marteau 1998 \{published data only\} Marteau P, Grand J, Foucault M, Rambaud J C. Use of mesalazine slow release suppositories $1 \mathrm{~g}$ three times per week to maintain remission of ulcerative proctitis: A randomised double blind placebo controlled multicentre study. Gut 1998;42:195-9.

\section{Mayer 1991 \{published data only\}}

Mayer L, Present D, Jannowitz H, Martin S, Rosenberg $\mathrm{R}$, Sachar D, et al. Effect of hydroxychloroquine in the treatment of active ulcerative colitis: a double blind controlled trial. Gastroenterology 1991;100:A229.

Miner 1991 \{published data only\} Miner P, Nostrant T, Wruble L, Hines C, Johnson S, Wilkinson C, et al. Multicenter trial of Pentasa for active ulcerative colitis. Gastroenterology 1991;100:A231.

Miner 1992 \{published data only\} Miner P, Schwartz J, Aora S, Robinson M, Hanauer S, Law $\mathrm{R}$, et al. Maintenance of remission in ulcerative colitis (UC) patients with controlled-release mesalamine capsules (Pentasa). Gastroenterology 1992;102:A666.

Miner 1994 \{published data only\}

Miner P, Daly R, Nester T, Group and the Rowasa Study. The effect of varying dose intervals of mesalamine enemas 
for the prevention of relapse in distal ulcerative colitis. Gastroenterology 1994; Vol. 106, issue Suppl 2:A736.

\section{Miner 1995 \{published data only\}}

Miner P, Hanauer S, Robinson M, Schwartz J, Arora S. Safety and efficacy of controlled-release mesalamine for maintenance of remission in ulcerative colitis. Pentasa UC Maintenance Study Group. Digestive Diseases \& Sciences 1995;40:296-304.

Moller 1978 \{published data only\}

Moller C, Kiviluoto O, Santavirta S, Holtz A. Local treatment of ulcerative proctitis with salicylazosulphapyridine (Salazopyrin) enema. Clinical Trials Journal 1978;15: 199-203.

Musch 2002 \{published data only\}

Musch E, Raedler A, Andus T, Kruis W, Schreiber S, Lorenz A, et al. A phase II placebo-controlled, randomized, multicenter study to evaluate efficacy and safety of interferon beta-1a in patients with ulcerative colitis. Gastroenterology 2002;122:A431.

Musch 2002a \{published data only\}

Musch E, Raedler A, Andus T, Kruis W, Schreiber S, Lorenz A, et al. Results of a randomised, double-blind, placebocontrolled, multi-centre, phase-II study to test the effectivity and tolerance of Interferon-beta-1a (CHO-beta) [rIFNbeta-1a] in patients with ulcerative colitis. Zeitschrift fur Gastroenterologie 2002; Vol. 40:705.

Musch 2005 \{published data only\}

Musch E, Andus T, Kruis W, Raedler A, Spehlmann M, Schreiber $S$, et al. Interferon-beta-1a for the treatment of steroid-refractory ulcerative colitis: a randomized, doubleblind, placebo-controlled trial. Clinical Gastroenterology \& Hepatology 2005;3:581-6.

Ngô 1992 \{published data only\}

Ngô Y, Gélinet J M, Ivanovic A, Kac J, Schénowitz G, Vilotte J, et al. Efficacy of a daily application of mesalazine (Pentasa) suppository with progressive release, in the treatment of ulcerative proctitis. A double-blind versus placebo randomized trial. Gastroentérologie Clinique et Biologique 1992; Vol. 16:782-6.

Nikolaus 2001 \{published data only\}

Nikolaus S, Rutgeerts P, Fedorak RN, Steinhart H, Wild GE, Theuer D, et al. Recombinant human interferonbeta (IFNb-1A) induces remission and is well tolerated in moderately active ulcerative colitis (UC). Gastroenterology 2001;120:A-454.

\section{Onuk 1996 \{published data only\}}

Onuk MD, Kaymakoglu S, Demir K, Çakaloglu Y, Baztas G, Mungan Z, et al. Low-dose weekly methotrexate therapy in remission maintenance in ulcerative colitis. Gut 1996; Vol. 39, issue Suppl 3:A75.

Orchard 2011 \{published data only\} Orchard TR, van der Geest SA, Travis SP. Randomised clinical trial: early assessment after 2 weeks of high-dose mesalazine for moderately active ulcerative colitis - new light on a familiar question. Alimentary Pharmacology \& Therapeutics 2011;33:1028-35.
Palmer 1981 \{published data only\}

Palmer K R, Goepel J R, Holdsworth C D. Sulphasalazine retention enemas in ulcerative colitis: a double-blind trial. British Medical Journal 1981; Vol. 282:1571-3.

Pastorelli 2008 \{published data only\} Pastorelli L, Saibeni S, Spina L, Signorelli C, Celasco G, De Franchis R, et al. Oral, colonic-release low-molecularweight heparin: an initial open study of Parnaparin-MMX for the treatment of mild-to-moderate left-sided ulcerative colitis. Alimentary Pharmacology and Therapeutics 2008;25 (8):581-8.

Piche 2008 \{published data only\}

Piche T. Rosiglitazone for active ulcerative colitis: A randomized placebo-controlled trial. Hépato-Gastro and Oncologie Digestive 2008;15:334-5.

Pokrotnieks, 2000 \{published data only\} Pokrotnieks J, Marlicz K, Paradowski L, Margus B, Zaborowski P, Greinwald R. Efficacy and tolerability of mesalazine foam enema (Salofalk foam) for distal ulcerative colitis: A double-blind, randomized, placebo-controlled study. Alimentary Pharmacology and Therapeutics 2000;14: 1191-8.

Present 2008 \{published data only\} Present DH, Sandborn WJ, Rutgeerts PJ, Olson A, Diamond RH, Johanns JR, et al. Infliximab treatment for ulcerative colitis: clinical response, clinical remission and mucosal healing in patients with moderate or severe disease in the Active Ulcerative Colitis Trials (ACT1 and ACT2). Gastroenterology 2008;134:A-493.

Pruitt 2008 \{published data only\} Pruitt RE, Rosen AA, Wruble L, Sedghi S, Shepard RD, Mareya SM, et al. Safety and tolerability of twice-daily balsalaside tablets: results of a phase 3 , randomized, double-blind, placebo-controlled, multicenter study. Gastroenterology 2008;134:A-494.

Pullan 1993 \{published data only\}

Pullan R D, Ganesh S, Mani V, Morris J, Evans B K, Williams G T, et al. Double-blind controlled trial of bismuth-carbomer and 5-aminosalicylcic acid (5-ASA) enemas in distal ulcerative colitis. Gastroenterology 1993; 104:A765.

Reinisch 2011a \{published data only\}

Reinisch W, Sandborn WJ, Kumar A, Pollack PF, Lazar A, Thakkar RB. 52-week clinical efficacy with adalimumab in patients with moderately to severely active ulcerative colitis who failed corticosteroids and/or immunosuppressants. Gut 2011;60:A139-40.

Reinisch 2012 \{published data only\}

Reinisch W, Sandborn WJ, Rutgeerts P, Feagan BG, Rachmilewitz D, Hanauer SB, et al. Long-term infliximab maintenance therapy for ulcerative colitis: the ACT-1 and 2 extension studies. Inflammatory Bowel Diseases 2012;18: 201-11.

Reinisch 2013 \{published data only\} Reinisch W, Sandborn W, Feagan B, Ghosh S, Robinson A, Skup M, et al. Association between week 8 mayo 
subscores and hospitalisation rates in adalimumab-treated patients with ulcerative colitis from ULTRA1 and ULTRA2. Inflammatory Bowel Diseases 2013;19:S80.

Reinisch 2014 \{published data only\}

Reinisch W, Gibson P, Sandborn WJ, Feagan BG, Marano $\mathrm{C}$, Strauss R, et al. Long-term safety and efficacy of golimumab in patients with moderately to severely active ulcerative colitis: Results from the PURSUIT-SC Maintenance study extension. Journal of Crohn's and Colitis 2014;8:S6-7.

Reinisch 2014a \{published data only\}

Reinisch W, Sandborn WJ, Feagan B, Ghosh S, Robinson A, Skup M, et al. Association between Week 8 Mayo subscores and hospitalisation rates in adalimumab-treated patients with ulcerative colitis from ULTRA 1 and ULTRA 2. Journal of Crohn's and Colitis 2014;8:S298.

Robinson 1988 \{published data only\} Robinson MG, Gitnick G, Balart L. Olsalazine in the treatment of mild to moderate ulcerative colitis. Gastroenterology 1988;94(5 Part 2):A381.

Rosenberg 1975 \{published data only\} Rosenberg JL, Wall AJ, Levin B, Binder HJ, Kirsner JB. A controlled trial of azathioprine in the management of chronic ulcerative colitis. Gastroenterology 1975;69:96-9.

Rutgeerts 2013d \{published data only\}

Rutgeerts P, Feagan BG, Marano C, Strauss R, Johanns J, Zhang $\mathrm{H}$, et al. Phase 3 study to evaluate the SC golimumab maintenance therapy in moderate to severe UC: Pursuitmaintenance. Journal of Gastroenterology and Hepatology 2013;28:593.

Rutgeerts 2013e \{published data only\}

Rutgeerts P, Feagan B, Marano C, Strauss R, Johanns J, Zhang $\mathrm{H}$, et al. Phase 2/3 randomized, placebo-controlled, double-blind study of SC golimumab induction in moderate to Severe UC. Journal of Gastroenterology and Hepatology 2013;28:591.

Sandborn 2009 \{published data only\}

Sandborn WJ, Colombel JF, Frankel M, Hommes D, Lowder J, Mayer L, et al. A placebo-controlled trial of visilizumab in patients with intravenous (IV) steroid refractory ulcerative colitis (UC). Gastroentrology 2009;136: 387.

Sandborn 2010 \{published data only\} Sandborn W, Targan S, Byers V, Tang T. Randomized, double-blind, placebo-controlled trial of andrographis paniculata extract (HMPL-004) in patients with moderately active Crohn's disease. American Journal of Gastroenterology 2010;105:S429-30.

Sandborn 2010a \{published data only\}

Sandborn WJ, Colombel JF, Frankel M, Hommes D, Lowder JN, Mayer L, et al. Anti-CD3 antibody visilizumab is not effective in patients with intravenous corticosteroidrefractory ulcerative colitis. Gut 2010; Vol. 59:1485-92.

Sandborn 2011 \{published data only\} Sandborn W, Travis S, Bala N, Danese S, Moro L, Ballard $\mathrm{ED}$, et al. Induction of clinical and endoscopic remission of mild to moderately active ulcerative colitis with budesonide MMX 9 mg: Analysis of pooled data from two phase 3 studies. American Journal of Gastroenterology 2011;106: S485.

Sandborn 2011a \{published data only\} Sandborn WJ, Hanauer S, Lichtenstein GR, Safdi M, Edeline M, Scott Harris M. Early symptomatic response and mucosal healing with mesalazine rectal suspension therapy in active distal ulcerative colitis - Additional results from two controlled studies. Alimentary Pharmacology and Therapeutics 2011;34:747-56.

Sandborn 2012 \{published data only\}

Sandborn WJ, Assche G, Reinisch W, Colombel JF, D'Haens G, Wolf DC, et al. Adalimumab induces and maintains clinical remission in patients with moderate-tosevere ulcerative colitis. Gastroenterology 2012; Vol. 142: 257-65.

Sandborn 2013 \{published data only\} Sandborn W, Hardiman Y, Huang M, Harris-Collazo R, Ballard ED, Travis S. Efficacy of budesonide MMX in reduction of symptoms in patients with mild-to-moderately active ulcerative colitis: A pooled analysis of the core I and core II studies. Gastroenterology 2013;1):S233-4.

Sandborn 2013c \{published data only\} Sandborn WJ, Targan SR, Byers VS, Rutty DA, Mu H, Zhang X, et al. Andrographis paniculata extract (HMPL004) for active ulcerative colitis. American Journal of Gastroenterology 2013; Vol. 108:90-8.

Sands 2001a \{published data only\} Sands B E, Tremaine W J, Sandborn W J, Rutgeerts P J, Hanauer S B, Mayer L, et al. Infliximab in the treatment of severe, steroid-refractory ulcerative colitis: a pilot study. Inflammatory Bowel Diseases 2001;7:83-8.

Sands 2001b \{published data only\} Sands BE, Tremaine WJ, Sandborn WJ, Rutgeerts PJ, Hanauer SB, Mayer L, et al. Infliximab in the treatment of severe, steroid-refractory ulcerative colitis: A pilot study. Inflammatory Bowel Diseases 2001;7(2):83-8.

\section{Sands 2014 \{published data only\}}

Sands B, Dubinsky M, Vermeire S, Sankoh S, Rosario M, Milch C. Effects of increased vedolizumab dosing frequency on disease activity in ulcerative colitis and Crohn's disease. American Journal of Gastroenterology 2014;109:S478-9.

Schreiber 2006 \{published data only\}

Schreiber S, Kamm M A, Lichtenstein G, Sandborn W J, D'Haens G, Barrett K, et al. MMX mesalazine, a novel formulation of 5-ASA given once or twice daily, is well tolerated in patients with active mild-to-moderate ulcerative colitis: an analysis of adverse events in combined data from three randomised studies. Gut 2006;55(Suppl 5):132.

Schreiber 2008a \{published data only\} Schreiber S. Maintenance of remission in patients with ulcerative colitis with once- or twice-daily MMX mesalazine: results of an international multicentre randomised trial. Zeitschrift für Gastroenterologie 2008; Vol. 46:944. 
Schreiber 2008b \{published data only\}

Schreiber S. The efficacy of MMX mesalazine as the sole medication for the induction and maintenance of remission in patients with mild-to-moderate ulcerative colitis treated over 14-16 months. Zeitschrift für Gastroenterologie 2008; Vol. 46:943-4.

Schulz 1973 \{published data only\}

Schulz U, Hanke P, Seige K. Rectal effect of salazopyrine in ulcerative colitis during a double-blind study. Wiener Zeitschrift fur Innere Medizin und Ihre Grenzgebiete 1973; Vol. 54:185-9.

Selby 1985 \{published data only\}

Selby W S, Barr G D, Ireland A. Olsalazine in active ulcerative colitis. British Medical Journal 1985;291:1373-5.

Solomon 2010 \{published data only\}

Solomon D, Abhyankar B, Barrett K, Karlstadt R. Evaluating induction and maintenance treatment with MMX mesalazine for patients with mild-to-moderate ulcerative colitis. Journal of Gastroenterology and Hepatology 2010;25:A90

Solomon 2011 \{published data only\}

Solomon D, Paridaens K, Palmen M, Barrett K, Streck P. Pooled safety analysis of long-term MMXVR, a mesalamine administration. Inflammatory Bowel Diseases 2011;17:S25.

Solomon 2012 \{published data only\}

Solomon D, Paridaens K, Palmen M, Barrett K, Streck P.

MMX, a mesalazine and long-term safety: a pooled analysis. Journal of Crohn's and Colitis 2012;6:S150.

Tao 2011 \{published data only\}

Tao X, Xu L, Shi R, Luo A, Shen J. Exposure-response analyses to support dose selection of BMS-936557, a monoclonal antibody to IP-10, for a phase $2 \mathrm{~b}$ study in patients with ulcerative colitis. Clinical Pharmacology and Therapeutics 2011;89:S62-3.

Tilg 2003 \{published data only\}

Tilg H, Vogelsang H, Ludwiczek O, Lochs H, Colombel JF, Rutgeerts P, et al. A randomized placebo-controlled trial of pegylated interferon alpha in active ulcerative colitis. Gastroenterology 2003;124:A62.

Tomecki 1985 \{published data only\}

Tomecki R, Butruk E. A trial of hydroxychloroquine administration in the treatment of exacerbated ulcerative colitis. Polskie Archiwum Medycyny Wewnetrznej 1985;73: $361-4$.

Touchefeu 2007 \{published data only\}

Touchefeu Y. Tacrolimus in refractory ulcerative rectocolitis treatment to a steroid therapy: A randomized study versus placebo. Hépato-Gastro \& Oncologie Digestive 2007;14: 78-9.

Travis 2005 \{published data only\}

Travis S, Yap LM, Hawkey C, Warren B, Lazarov M, Fong T, et al. RDP58 is a novel and potentially effective oral therapy for ulcerative colitis. Inflammatory Bowel Diseases 2005;11:713-9.
Travis 2011 \{published data only\}

Travis S, David Ballard E, Bagin B, Gautille T, Huang M. Induction of remission with oral budesonide MMXVR $(9 \mathrm{mg})$ tablets in patients with mild to moderate, active Ulcerative Colitis: A multicenter, open-label efficacy and safety study. Inflammatory Bowel Diseases 2011;17:S20.

Travis 2012 \{published data only\}

Travis S, Danese S, Moro L, Ballard ED, Bagin R, Gautille $\mathrm{T}$, et al. Induction of clinical and endoscopic remission with budesonide MMX in mild to moderately active ulcerative colitis: Pooled data from two phase 3 studies. Journal of Crohn's and Colitis 2012;6:S74.

Truelove 1955 \{published data only\} Truelove SC, Whitts LJ. Cortisone in ulcerative colitis. Final report on a therapeutic trial. British Medical Journal 1955;4947:1041-8.

Truelove 1958 \{published data only\} Truelove SC, Hambling MH. Treatment of ulcerative colitis with local hydrocortisone hemisuccinate sodium: a report on a controlled therapeutic trial. British Medical Journal 1958; Vol. 2, issue 5104:1072-7.

Truelove 1960 \{published data only\} Truelove SC. Systemic and local corticosteroid therapy in ulcerative colitis. British Medical Journal 1960; Vol. 1: 464-7.

Van Hees 1980 \{published data only\} Van Hees PAM, Bakker JH, Van Tongeren JHM. Effect of sulphapyridine, 5-aminosalicylic acid, and placebo in patients with idiopathic proctitis: A study to determine the active therapeutic moiety of sulphasalazine. Gut 1980;21: $632-5$.

Watkinson 1958 \{published data only\}

Watkinson G. Treatment of ulcerative colitis with topical hydrocortisone hemisuccinate sodium: a controlled trial employing restricted sequential analysis. British Medical Journal 1958; Vol. 2, issue 5104:1077-82.

Wright 1993 \{published data only\} Wright JP, O'Keefe EA, Cumming L, Jaskiewicz K. Olsalazine in maintenance of clinical remission in patients with ulcerative colitis. Digestive Diseases and Sciences 1993; Vol. 38, issue 10:1837-42.

Zakko 2009 \{published data only\}

Zakko S, Gordon GL, Murthy UK, Sedghi S, Pruitt RE, Merchant K, et al. Once-daily mesalamine granules effectively maintain remission from ulcerative colitis: Data from 2 phase 3 trials. Gastroenterology 2009;1):A521.

Zinberg 1990 \{published data only\} Zinberg J, Molinas S, Das KM. Double-blind placebocontrolled study of olsalazine in the treatment of ulcerative colitis. American Journal of Gastroenterology 1990; Vol. 85 , issue 5:562-6.

\section{References to studies awaiting assessment}

Atreya 2016a \{published data only\}

Atreya R, Bloom S, Scaldaferri F, Gerardi V, Admyre C, Karlsson A, et al. Clinical effects of a topically applied

Placebo response and remission rates in randomised trials of induction and maintenance therapy for ulcerative colitis (Review)

Copyright @ 2017 The Cochrane Collaboration. Published by John Wiley \& Sons, Ltd. 
toll-like receptor 9 agonist in active moderate-to-severe ulcerative colitis. Journal of Crohn's and Colitis 2016;10(11): 1294-1302.

\section{Harris 2016a \{published data only\}}

Harris MS, Hartman D, Lemos BR, Erlich EC, Spence S, Kennedy S, Ptak T, et al. AVX-470, an orally delivered anti-tumour necrosis factor antibody for treatment of active ulcerative colitis: results of a first-in-human trial. Journal of Crohn's and Colitis 2016;10(6):631-40.

Kucharzik 2017 \{published data only\}

Kucharzik T, Lemmnitz G, Abels C, Maaser C. Tripeptide $\mathrm{K}(\mathrm{D}) \mathrm{PT}$ Is well tolerated in mild-to-moderate ulcerative colitis: results from a randomized multicenter study. Inflammatory Bowel Diseases 2017;23(2):261-71.

Naganuma 2016a \{published data only\}

Naganuma M, Aoyama N, Suzuki Y, Nishino H, Kobayashi $\mathrm{K}$, Hirai F, et al. Twice-daily budesonide 2-mg foam induces complete mucosal healing in patients with distal ulcerative colitis. Journal of Crohn's and Colitis 2016;10(7):828-36.

Sandborn 2016a \{published data only\}

Sandborn WJ, Colombel JF, Ghosh S, Sands BE, Dryden G, Hébuterne X, et al. Eldelumab [Anti-IP-10] induction therapy for ulcerative colitis: a randomised, placebocontrolled, phase 2b study. Journal of Crohn's and Colitis 2016;10(4):418-28.

Sandborn 2016b \{published data only\}

Sandborn WJ, Feagan BG, Wolf DC, D'Haens G, Vermeire $S$, Hanauer SB, et al. Ozanimod induction and maintenance treatment for ulcerative colitis. New England Journal of Medicine 2016;374(18):1754-62.

\section{Sandborn 2016c \{published data only\}}

Sandborn W, Sands BE, D'Haens GR, Vermeire S, Schreiber $S$, Danese $S$, et al. Efficacy and safety of oral tofacitinib as induction therapy in patients with moderate to severe ulcerative colitis: results from two phase 3 randomized controlled trials. Gastroenterology 2016;4(Supp 1):S157.

Sandborn 2016d \{published data only\} Sandborn WJ, Bhandari BR, Fogel R, Onken J, Yen E, Zhao $\mathrm{X}$, et al. Randomised clinical trial: a phase 1, dose-ranging study of the anti-matrix metalloproteinase- 9 monoclonal antibody GS-5745 versus placebo for ulcerative colitis. Alimentary Pharmacology and Therapeutics 2016;44(2): $157-69$

Van Assche 2016 \{published data only\}

Van Assche G, Rutgeerts P, Ferrante M, Noman M, Fidder H, Oldenburg B, et al. Safety and efficacy of a novel IV targeted pegylated liposomal prednisolone product (Nanocort): results from a phase 2a study in patients with active ulcerative colitis. Journal of Crohn's and Colitis 2016; 10(Supp 1):S39-40.

\section{Additional references}

\section{Dieppe 2013}

Dieppe P. Trial designs and exploration of the placebo response. Complementary Therapies in Medicine 2013;21: $105-8$.

\section{Duval 2000}

Duval S, Tweedie R. Trim and fill: A simple funnel-plotbased method of testing and adjusting for publication bias in meta-analysis. Biometrics 2000;56(2):455-63.

\section{Egger 1997a}

Egger M, Davey Smith G, Schneider M, Minder C. Bias in meta-analysis detected by a simple, graphical test. $B M J$ 1997;315(7109):629-34.

\section{Enck 2013}

Enck P, Bingel U, Schedlowski M, Rief W. The placebo response in medicine: minimize, maximize or personalize?. Nature Reviews Drug Discovery 2013;12(3):191-204.

\section{Higgins 2002}

Higgins JP, Thompson SG. Quantifying heterogeneity in a meta-analysis. Statistics in Medicine 2002;21(11):1539-58.

\section{Higgins 2011a}

Higgins JPT, Deeks JJ (editors). Chapter 7: Selecting studies and collecting data. In: Higgins JPT, Green S editor(s). Cochrane Handbook for Systematic Reviews of Interventions Version 5.1.0 (updated March 2011). The Cochrane Collaboration, 2011. Available from www.cochrane-handbook.org.

\section{Higgins 2011b}

Higgins JPT, Altman DG, Sterne JAC (editors). Chapter 8: Assessing risk of bias in included studies. In: Higgins JPT, Green S editor(s). Cochrane Handbook for Systematic Reviews of Interventions Version 5.1.0 (updated March 2011). The Cochrane Collaboration, 2011. Available from www.cochrane-handbook.org.

Jairath 2016

Jairath V, Zou G, Parker CE, MacDonald JK, Mosli MH, Khanna R, et al. Systematic review and meta-analysis: placebo rates in induction and maintenance trials of ulcerative colitis. Journal of Crohn's and Colitis 2016;10(5): $607-18$.

\section{Rief 2009}

Rief W, Nestoriuc Y, Weiss S, Welzel E, Barsky AJ, Hofmann $S G$. Meta-analysis of the placebo response in antidepressant trials. Journal of Affective Disorders 2009;118:1-8.

Schmid 2004

Schmid CH, Cappelleri JC, Lau J. Bayesian methods to improve sample size approximations. Methods in Enzymology 2004;383:406-27.

\section{Stijnen 2010}

Stijnen T, Hamza TH, Ozdemir P. Random effects meta-analysis of event outcome in the framework of the generalized linear mixed model with applications in sparse data. Statistics in Medicine 2010;29(29):3046-67.

Su 2007

Su C, Lewis JD, Goldberg B, Brensinger C, Lichtenstein GR. A meta-analysis of the placebo rates of remission 
and response in clinical trials of active ulcerative colitis.

Gastroenterology 2007;132(2):516-26.

Thompson 2002

Thompson SG, Higgins JP. How should meta-regression analyses be undertaken and interpreted?. Statistics in Medicine 2002;21(11):1559-73.

* Indicates the major publication for the study 


\section{CHARACTERISTICS OFSTUDIES}

\section{Characteristics of included studies [ordered by study ID]}

Aoyama 2015

Methods

Participants

Interventions
Multicenter, randomised, double-blind, placebo-controlled trial $(\mathrm{N}=165)$

Patients with active, mild-to-moderate UC

Group 1: budesonide foam $(2 \mathrm{mg} / 25 \mathrm{~mL})$ once daily

Group 2: budesonide foam $(2 \mathrm{mg} / 25 \mathrm{~mL})$ twice daily

Group 3: placebo

Primary outcome: remission at week 6 (rectal bleeding subscore $=0$, endoscopic subscore $<1$ and stool frequency subscore $=0$ or decrease $>1$ )

Notes

Reported in abstract form only (unclear how many patients randomised to each group) ; not included in quantitative synthesis

\section{Risk of bias}

\begin{tabular}{l|lll}
\hline Bias & Authors' judgement & Support for judgement \\
\hline $\begin{array}{l}\text { Random sequence generation (selection } \\
\text { bias) }\end{array}$ & Unclear risk & Not described \\
\hline $\begin{array}{l}\text { Allocation concealment (selection bias) } \\
\text { Blinding of participants and personnel } \\
\text { (performance bias) } \\
\text { All outcomes }\end{array}$ & Unclear risk & Not described \\
\hline $\begin{array}{l}\text { Blinding of outcome assessment (detection } \\
\text { bias) } \\
\text { All outcomes }\end{array}$ & Unclear risk & Not described \\
\hline $\begin{array}{l}\text { Incomplete outcome data (attrition bias) } \\
\text { All outcomes }\end{array}$ & Unclear risk & Not described \\
\hline $\begin{array}{l}\text { Selective reporting (reporting bias) } \\
\text { Other bias }\end{array}$ & Low risk & Not described \\
\hline
\end{tabular}


Beeken 1997

\begin{tabular}{|c|c|c|}
\hline Methods & \multicolumn{2}{|c|}{6 week, randomised, double-blind, placebo-controlled, multi-centre trial $(\mathrm{N}=30)$} \\
\hline Participants & \multicolumn{2}{|c|}{$\begin{array}{l}30 \text { subjects with mild-to-moderate disease } \\
\text { Patients were grouped according to disease extent }(14 \text { in the distal }(<60 \mathrm{~cm}) \text { group; } 16 \\
\text { in the more extensive }(>60 \mathrm{~cm}) \text { group) }\end{array}$} \\
\hline Interventions & \multicolumn{2}{|c|}{$\begin{array}{l}\text { Group 1: 4-ASA } 6 \mathrm{~g}(\mathrm{n}=17) \\
\text { Group 2: placebo }(\mathrm{n}=13) \\
6 \text { capsules administered twice daily to each group }\end{array}$} \\
\hline Outcomes & \multicolumn{2}{|c|}{$\begin{array}{l}\text { Primary outcomes: clinical improvement, adverse events and abnormalities in laboratory } \\
\text { tests }\end{array}$} \\
\hline \multicolumn{3}{|l|}{ Notes } \\
\hline \multicolumn{3}{|l|}{ Risk of bias } \\
\hline Bias & Authors' judgement & Support for judgement \\
\hline $\begin{array}{l}\text { Random sequence generation (selection } \\
\text { bias) }\end{array}$ & Unclear risk & Not described \\
\hline Allocation concealment (selection bias) & Unclear risk & Not described \\
\hline $\begin{array}{l}\text { Blinding of participants and personnel } \\
\text { (performance bias) } \\
\text { All outcomes }\end{array}$ & Unclear risk & Not described beyond 'matched placebo' \\
\hline $\begin{array}{l}\text { Blinding of outcome assessment (detection } \\
\text { bias) } \\
\text { All outcomes }\end{array}$ & Unclear risk & Not described \\
\hline $\begin{array}{l}\text { Incomplete outcome data (attrition bias) } \\
\text { All outcomes }\end{array}$ & Low risk & $\begin{array}{l}\text { Drop-outs balanced across treatment } \\
\text { groups }\end{array}$ \\
\hline Selective reporting (reporting bias) & Low risk & All expected outcomes were reported \\
\hline Other bias & Low risk & $\begin{array}{l}\text { The study appears to be free of other } \\
\text { sources of bias }\end{array}$ \\
\hline
\end{tabular}

Carbonnel 2016

Methods

Participants
A prospective, controlled, randomised, double-blind trial $(\mathrm{N}=111)$

Patients with steroid-dependent, active or inactive UC receiving prednisone at a daily dose of 10 to $40 \mathrm{mg}$ at inclusion 


\section{Carbonnel 2016 (Continued)}

\begin{tabular}{l|l} 
Interventions & $\begin{array}{l}\text { Group 1: intra-muscular or SC methotrexate } 25 \mathrm{mg} / \mathrm{week} \\
\text { Group 2: placebo }\end{array}$ \\
\hline Outcomes & $\begin{array}{l}\text { Primary outcome: success at week } 16 \text { (Mayo score }<\text { or }=2 \text { with no item }>1 \text {, complete } \\
\text { steroid withdrawal with a forced tapering regimen, and no need for other immunosup- } \\
\text { pressant, tumour necrosis factor-alpha (TNF- } \alpha \text { ) antagonist or colectomy) } \\
\text { Secondary outcomes: success at week 24, success at week } 16 \text { and 24, mucosal healing, } \\
\text { clinical remission }\end{array}$ \\
\hline Notes &
\end{tabular}

\section{Risk of bias}

\begin{tabular}{|c|c|c|}
\hline Bias & Authors' judgement & Support for judgement \\
\hline $\begin{array}{l}\text { Random sequence generation (selection } \\
\text { bias) }\end{array}$ & Unclear risk & Not described \\
\hline Allocation concealment (selection bias) & Unclear risk & Not described \\
\hline $\begin{array}{l}\text { Blinding of participants and personnel } \\
\text { (performance bias) } \\
\text { All outcomes }\end{array}$ & Unclear risk & Not described beyond 'double-blind' \\
\hline $\begin{array}{l}\text { Blinding of outcome assessment (detection } \\
\text { bias) } \\
\text { All outcomes }\end{array}$ & Unclear risk & Not described \\
\hline $\begin{array}{l}\text { Incomplete outcome data (attrition bias) } \\
\text { All outcomes }\end{array}$ & Unclear risk & Drop-outs not reported \\
\hline Selective reporting (reporting bias) & Low risk & All expected outcomes were reported \\
\hline Other bias & Low risk & $\begin{array}{l}\text { The study appears to be free of other } \\
\text { sources of bias }\end{array}$ \\
\hline
\end{tabular}

\section{Danese 2014}

Methods

Participants
Randomised, double-blind, placebo-controlled, phase IIa, parallel-group, multicentre trial conducted at 30 sites in 6 countries $(\mathrm{N}=111)$

Non-hospitalised adults with UC (total Mayo score $<6$ )

Diagnosis verified by endoscopy and biopsy at least 90 days prior to randomisation All enrolled patients had been treated with medication containing 5-ASA at a stable dose for at least 2 weeks prior to randomisation, with the exception of individuals who had been treated with 5-ASA medications at the maximum dose without significant improvement/those who had to discontinue

Concomitant therapy with glucocorticosteroids (prednisolone $\leq 20 \mathrm{mg}$ daily or equiva- 
Danese 2014 (Continued)

lent), was permitted if unchanged for at least 4 weeks prior to randomisation Concomitatant therapy with purine analogues (AZA or 6-MP) was permitted if unchanged for at least 12 weeks prior to randomisation

Interventions

Patients received SC tralokinumab $300 \mathrm{mg}(\mathrm{n}=56)$ or placebo $(\mathrm{n}=55)$ every 2 weeks in a $1: 1$ ratio

12 week treatment period and 12 week follow-up period

Outcomes

Primary outcome: clinical response at week 8

Secondary outcomes: clinical remission and mucosal healing at week 8 and changes in total Mayo score, total modified Riley score, partial Mayo score and disease activity markers (CRP, albumin, faecal calprotectin)

Notes

Risk of bias

\begin{tabular}{|c|c|c|}
\hline Bias & Authors' judgement & Support for judgement \\
\hline $\begin{array}{l}\text { Random sequence generation (selection } \\
\text { bias) }\end{array}$ & Low risk & Computer-generated randomisation list \\
\hline Allocation concealment (selection bias) & Low risk & $\begin{array}{l}\text { Randomisation took place via an interac- } \\
\text { tive voice or web response system at the end } \\
\text { of the enrolment period }\end{array}$ \\
\hline $\begin{array}{l}\text { Blinding of participants and personnel } \\
\text { (performance bias) } \\
\text { All outcomes }\end{array}$ & Low risk & Double-blind trial with identical placebo \\
\hline $\begin{array}{l}\text { Blinding of outcome assessment (detection } \\
\text { bias) } \\
\text { All outcomes }\end{array}$ & Unclear risk & Not described \\
\hline $\begin{array}{l}\text { Incomplete outcome data (attrition bias) } \\
\text { All outcomes }\end{array}$ & Low risk & $\begin{array}{l}\text { Drop-outs were balanced across groups } \\
\text { with similar reasons for withdrawal } \\
\text { (13/56 discontinued from treatment } \\
\text { group, } 18 / 55 \text { from placebo) }\end{array}$ \\
\hline Selective reporting (reporting bias) & Low risk & All expected outcomes were reported \\
\hline Other bias & Low risk & $\begin{array}{l}\text { The study appears to be free of other } \\
\text { sources of bias }\end{array}$ \\
\hline
\end{tabular}


Deventer 2004

\begin{tabular}{ll}
\hline Methods & Randomised, controlled, double blind, escalating dose study $(\mathrm{N}=40)$ \\
\hline Participants & $\begin{array}{l}\text { Patients }>18 \text { years with active distal UC extending } 5-50 \mathrm{~cm} \text { from the anal verge with a } \\
\text { UCDAI score of } 3-10 \text { points } \\
\text { Patients received a stable oral dose of } 5 \text {-ASA }(1500-3000 \mathrm{mg}) \text { or no background oral } \\
\text { therapy (except antidiarrhoeals and analgesics) for } 2 \text { months prior to the study }(37 / 40 \\
\text { were on a stable dose of } 5 \text {-ASA at enrolment) }\end{array}$ \\
\hline Interventions & $\begin{array}{l}\text { Cohort } 1: 0.1 \mathrm{mg} / \mathrm{ml} \text { alicaforsen enema }(\mathrm{n}=8) \\
\text { Cohort } 2: 0.5 \mathrm{mg} / \mathrm{ml} \text { alicaforsen enema }(\mathrm{n}=8) \\
\text { Cohort } 3: 2 \mathrm{mg} / \mathrm{ml} \text { alicaforsen enema }(\mathrm{n}=8) \\
\text { Cohort } 4: 4 \mathrm{mg} / \mathrm{ml} \text { alicaforsen enema }(\mathrm{n}=8) \\
\text { Each cohort contained } 2 \text { patients who received placebo enema (n }=8)\end{array}$ \\
\hline Outcomes & $\begin{array}{l}\text { Primary outcome: clinical response measured by the UCDAI and the CAI } \\
\text { Seconary outcomes: individual components of the UCDAI, alicaforsen drug concentra- } \\
\text { tion and adverse events }\end{array}$ \\
\hline Notes & \begin{tabular}{l}
\hline \\
\hline
\end{tabular}
\end{tabular}

\section{Risk of bias}

\begin{tabular}{|c|c|c|}
\hline Bias & Authors' judgement & Support for judgement \\
\hline $\begin{array}{l}\text { Random sequence generation (selection } \\
\text { bias) }\end{array}$ & Low risk & $\begin{array}{l}\text { Patients were sequentially randomised to } \\
4 \text { cohorts of } 10 \text { patients each ( } 8 \text { to study } \\
\text { drug, } 2 \text { to placebo) to receive study drug or } \\
\text { placebo }\end{array}$ \\
\hline Allocation concealment (selection bias) & Low risk & Pharmacy controlled randomisation \\
\hline $\begin{array}{l}\text { Blinding of participants and personnel } \\
\text { (performance bias) } \\
\text { All outcomes }\end{array}$ & Low risk & $\begin{array}{l}\text { Each enema bottle was labelled with a } \\
\text { unique reference number and a scratch off } \\
\text { code to blind the investigators, study mon- } \\
\text { itors, and patients to treatment assignment }\end{array}$ \\
\hline $\begin{array}{l}\text { Blinding of outcome assessment (detection } \\
\text { bias) } \\
\text { All outcomes }\end{array}$ & Unclear risk & Not described \\
\hline
\end{tabular}

Incomplete outcome data (attrition bias) Low risk All outcomes
Drop-outs were balanced across groups with similar reasons for withdrawal $39 / 40$ and $24 / 40$ patients completed the study through to months 2 and 6 , respectively

16 patients did not complete the study (15 due to worsening disease and 1 patient for an adverse event)

The ITT population was used for analysis 


\section{Deventer 2004 (Continued)}

\begin{tabular}{|c|c|c|}
\hline Selective reporting (reporting bias) & Low risk & All expected outcomes were reported \\
\hline Other bias & Low risk & $\begin{array}{l}\text { The study appears to be free of other } \\
\text { sources of bias }\end{array}$ \\
\hline
\end{tabular}

Deventer 2006

Methods

$(\mathrm{N}=112)$

Participants

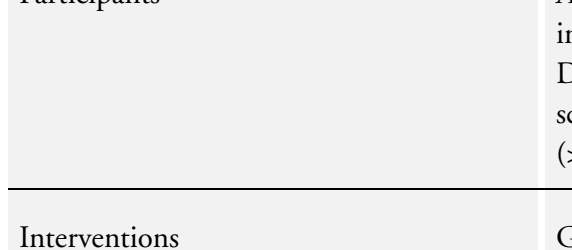

Interventions

\section{2)}

Group 2: $240 \mathrm{mg}$ alicaforsen every other day $(\mathrm{n}=23)$

Group 3: $240 \mathrm{mg}$ alicaforsen daily for 10 days and then every other day $(\mathrm{n}=23)$

Group 4: $240 \mathrm{mg}$ alicaforsen daily $(\mathrm{n}=22)$

Group 5: placebo $(\mathrm{n}=22)$
Primary outcome: UCDAI at week 6

Secondary outcomes: clinical improvement, relapse rates and durability of response

Notes

\section{Risk of bias}

\begin{tabular}{|c|c|c|}
\hline Bias & Authors' judgement & Support for judgement \\
\hline $\begin{array}{l}\text { Random sequence generation (selection } \\
\text { bias) }\end{array}$ & Unclear risk & Not described \\
\hline Allocation concealment (selection bias) & Unclear risk & Not described \\
\hline $\begin{array}{l}\text { Blinding of participants and personnel } \\
\text { (performance bias) } \\
\text { All outcomes }\end{array}$ & Unclear risk & Not described beyond 'double-blind' \\
\hline $\begin{array}{l}\text { Blinding of outcome assessment (detection } \\
\text { bias) } \\
\text { All outcomes }\end{array}$ & Unclear risk & Not described \\
\hline
\end{tabular}

Incomplete outcome data (attrition bias) Low risk All outcomes
Drop-outs balanced across intervention groups with similar reasons for withdrawal 
Deventer 2006 (Continued)

\begin{tabular}{|c|c|c|}
\hline Selective reporting (reporting bias) & Low risk & All expected outcomes were reported \\
\hline Other bias & Low risk & $\begin{array}{l}\text { The study appears to be free of other } \\
\text { sources of bias }\end{array}$ \\
\hline
\end{tabular}

Feagan 2000

\begin{tabular}{ll}
\hline Methods & A double-blind, placebo-controlled, ascending dose trial of LDP-02 (N =29) \\
\hline Participants & $\begin{array}{l}\text { Patients with active UC and a minimum MCS of 5, }>3 \text { bowel movements daily compared } \\
\text { with baseline, and endoscopic evidence of active disease }\end{array}$ \\
\hline Interventions & $\begin{array}{l}\text { Group } 1: \mathrm{LDP}-020.15 \mathrm{mg} / \mathrm{kg} \mathrm{SC}(\mathrm{n}=5) \\
\text { Group 2: LDP-02 } 0.15 \mathrm{mg} / \mathrm{kg} \text { intravenously }(\mathrm{IV})(\mathrm{n}=5) \\
\text { Group 3: LDP-02 } 0.5 \mathrm{mg} / \mathrm{kg} \mathrm{IV}(\mathrm{n}=5) \\
\text { Group 4: LDP-02 } 2.0 \mathrm{mg} / \mathrm{kg} \mathrm{IV}(\mathrm{n}=5) \\
\text { Group 5: placebo }(\mathrm{n}=8)\end{array}$ \\
\hline Outcomes & $\begin{array}{l}\text { Primary outcome: } \mathrm{meaningful} \mathrm{endoscopic} \mathrm{response}(2 \text { grade improvement }) \\
\text { Secondary outcomes: endoscopic remission, clinical remission, adverse events }\end{array}$ \\
\hline Notes & Reported in abstract form only \\
\hline
\end{tabular}

\section{Risk of bias}

\begin{tabular}{l|lll}
\hline Bias & Authors' judgement & Support for judgement \\
\hline $\begin{array}{l}\text { Random sequence generation (selection } \\
\text { bias) }\end{array}$ & Unclear risk & Not described \\
\hline $\begin{array}{l}\text { Allocation concealment (selection bias) } \\
\text { Blinding of participants and personnel } \\
\text { (performance bias) } \\
\text { All outcomes }\end{array}$ & Unclear risk & Not described \\
\hline $\begin{array}{l}\text { Blinding of outcome assessment (detection } \\
\text { bias) } \\
\text { All outcomes }\end{array}$ & Unclear risk & Not described \\
\hline $\begin{array}{l}\text { Incomplete outcome data (attrition bias) } \\
\text { All outcomes }\end{array}$ & Unclear risk & Not described \\
\hline $\begin{array}{l}\text { Selective reporting (reporting bias) } \\
\text { (n) }\end{array}$ & Low risk & $\begin{array}{l}\text { The study states that 29 patients were eval- } \\
\text { uated, but endoscopic response was only } \\
\text { reported for 28 patients in the results sec- } \\
\text { tion }\end{array}$ \\
\hline
\end{tabular}

Placebo response and remission rates in randomised trials of induction and maintenance therapy for ulcerative colitis (Review) 


\begin{tabular}{lll}
\hline Other bias & Unclear risk & Reported in abstract form only
\end{tabular}

Feagan 2005

\begin{tabular}{|c|c|}
\hline Methods & $\begin{array}{l}\text { Randomised, double-blind, placebo-controlled, } 8 \text { week induction trial involving } 20 \text { cen- } \\
\text { tres }(\mathrm{N}=81)\end{array}$ \\
\hline Participants & $\begin{array}{l}\text { Patients with moderately active UC clinical activity index (CAI) } 5-9 \text {, with either stool } \\
\text { frequency or rectal bleeding score }>1 \text {, and a modified Baron score of }>2 \text {, with disease } \\
\text { minimum } 25 \mathrm{~cm} \text { from anal verge) }\end{array}$ \\
\hline Interventions & $\begin{array}{l}\text { Group 1: MLN02 } 0.5 \mathrm{mg} / \mathrm{kg}(\mathrm{n}=58) \\
\text { Group 2: MLN02 } 2 \mathrm{mg} / \mathrm{kg}(\mathrm{n}=60) \\
\text { Group 3: placebo }(\mathrm{n}=63) \\
\text { IV administration on days } 1 \text { and } 29\end{array}$ \\
\hline Outcomes & $\begin{array}{l}\text { Primary outcome: Clinical remission at week } 6 \text { (defined as an UC clinical score of } 0 \text { or } \\
1 \text { and a modified Baron score of } 0 \text { or } 1 \text { with no evidence of rectal bleeding) } \\
\text { Secondary outcomes: Changes in CAI, Riley scores, and IBDQ scores, proportion of } \\
\text { subjects with clinical response (defined as a decrease of } 3 \text { or more on the MCS) at week } \\
4 \text { and } 6 \text {, endoscopic remission (defined as a modified Baron score of } 0 \text { ) at week } 4 \text { and } 6 \text {, } \\
\text { endoscopic response (defined as a } 2 \text { or more grade improvement in the modified Baron } \\
\text { score) at week } 4 \text { and } 6 \text {, patients were evaluated at baseline and } 1,2,4 \text { and } 6 \text { weeks after } \\
\text { randomisation, sigmoidoscopy was performed at weeks } 0,4 \text { and } 6\end{array}$ \\
\hline
\end{tabular}

Notes

Risk of bias

\begin{tabular}{|c|c|c|}
\hline Bias & Authors' judgement & Support for judgement \\
\hline $\begin{array}{l}\text { Random sequence generation (selection } \\
\text { bias) }\end{array}$ & Low risk & $\begin{array}{l}\text { Computer-generated block randomisation } \\
\text { schedule }\end{array}$ \\
\hline Allocation concealment (selection bias) & Low risk & Centralised randomisation \\
\hline $\begin{array}{l}\text { Blinding of participants and personnel } \\
\text { (performance bias) } \\
\text { All outcomes }\end{array}$ & Low risk & $\begin{array}{l}\text { Neither the investigators nor the patients } \\
\text { were aware of treatment assignment } \\
\text { Placebo was identical to MLN02 }\end{array}$ \\
\hline $\begin{array}{l}\text { Blinding of outcome assessment (detection } \\
\text { bias) } \\
\text { All outcomes }\end{array}$ & Low risk & $\begin{array}{l}\text { The study was designed and implemented } \\
\text { by the steering committee in collaboration } \\
\text { with Millennium Pharmaceuticals, which } \\
\text { analysed the data }\end{array}$ \\
\hline $\begin{array}{l}\text { Incomplete outcome data (attrition bias) } \\
\text { All outcomes }\end{array}$ & Low risk & $\begin{array}{l}\text { Attrition rates were balanced across the } \\
\text { groups with similar reasons for withdrawal } \\
(2 \%, 8 \% \text { and } 5 \% \text { for the MLN02 } 0.5 \mathrm{mg} /\end{array}$ \\
\hline
\end{tabular}

Placebo response and remission rates in randomised trials of induction and maintenance therapy for ulcerative colitis (Review) 
Feagan 2005 (Continued)

$\mathrm{kg}$, MLN02 $2.0 \mathrm{mg} / \mathrm{kg}$ and placebo groups, respectively)

\begin{tabular}{|c|c|c|}
\hline Selective reporting (reporting bias) & Low risk & All expected outcomes reported \\
\hline Other bias & Low risk & $\begin{array}{l}\text { The study appears to be free of other } \\
\text { sources of bias }\end{array}$ \\
\hline
\end{tabular}

Feagan 2013a

Methods

Participants

Participants

Interventions
Randomised, double-blind, placebo-controlled, multicenter, phase III study ( $\mathrm{N}=281$ )

Adult patients (> 18 years) with mild-to-moderate UC were eligible to participate if they had: disease extending at least $15 \mathrm{~cm}$ from the anal verge; and, mild-to-moderately active UC defined by a modified UCDAI score between 4-10 with a sigmoidoscopy component score 2 and a rectal bleeding component score 1

Group 1: mesalamine $4.8 \mathrm{~g} /$ day $(\mathrm{n}=141)$

Group 2: placebo $(\mathrm{n}=140)$

Three tablets were given twice daily

Outcomes
Primary outcome: clinical remission (UCDAI, stool frequency and bleeding scores of 0 , and no fecal urgency) at week 6

Secondary outcomes: clinical remission at week 10, clinical remission at both weeks 6 and 10, endoscopic remission

(defined as a sigmoidoscopic score of 1 ) at week 6, endoscopic remission at week 10 , improvement (defined as a

decrease of at least 3 points from baseline in the modified UCDAI score) at week 6 , improvement at week 10, and the mean changes in the modified UCDAI and UCCS from baseline to week 10

Notes

Risk of bias

\begin{tabular}{|c|c|c|}
\hline Bias & Authors' judgement & Support for judgement \\
\hline $\begin{array}{l}\text { Random sequence generation (selection } \\
\text { bias) }\end{array}$ & Low risk & $\begin{array}{l}\text { Randomisation schedule was generated in } \\
\text { permutated blocks by a computer }\end{array}$ \\
\hline Allocation concealment (selection bias) & Low risk & $\begin{array}{l}\text { An interactive voice/web response system } \\
\text { was used to manage the randomisation pro- } \\
\text { cedure and dispense study drug }\end{array}$ \\
\hline $\begin{array}{l}\text { Blinding of participants and personnel } \\
\text { (performance bias) } \\
\text { All outcomes }\end{array}$ & Low risk & $\begin{array}{l}\text { Study was double-blind and patients re- } \\
\text { ceived an identical placebo }\end{array}$ \\
\hline
\end{tabular}

Placebo response and remission rates in randomised trials of induction and maintenance therapy for ulcerative colitis (Review) 
Feagan 2013a (Continued)

Blinding of outcome assessment (detection Low risk

bias)

All outcomes
Endoscopic images were reviewed by a single expert central reader who was blind to treatment assignment

All of the efficacy outcomes were analysed according to the ITT principle

213 patients completed the study $(84.3 \%$ in the mesalamine group and $67.4 \%$ in the placebo group)

Adverse events were the most frequent cause of early withdrawal, and worsening of UC was the most common reason for withdrawal

All expected outcomes were reported

The study appears to be free of other sources of bias

Feagan 2013b

Methods

Participants

Interventions
Randomised, double-blind, placebo-controlled trial with a 6 week induction $(\mathrm{N}=374)$ and a 6 week open-label phase $(\mathrm{N}=521)$ followed by a 46 week maintenance phase $(\mathrm{N}$ $=373$ )

Patients 18-80 years with Mayo scores of $>6$ and an endoscopic subscore of $>2$ despite treatment with corticosteroids, purine antimetabolites and/or TNF- $\alpha$ antagonists

\section{Induction}

Cohort 1: IV vedolizumab $300 \mathrm{mg}(\mathrm{n}=225)$ or placebo $(\mathrm{n}=149)$

Cohort 2: open-label IV vedolizumab $300 \mathrm{mg}(\mathrm{n}=521)$

Maintenance

IV vedolizumab $300 \mathrm{mg}(\mathrm{n}=122)$ every 8 weeks, every 4 weeks $(\mathrm{n}=125)$ or placebo $(\mathrm{n}$ $=126)$

Outcomes

Induction

Primary outcome: clinical response at week 6

Secondary outcomes: clinical remission at week 6

Maintenance

Primary outcome: clinical remission at week 52

Secondary outcomes: durable clinical response at weeks 6 and 52, durable clinical remission at weeks 6 and 52, mucosal healing at week 52, and glucocorticoid-free remission at week 52

Notes

Risk of bias

Placebo response and remission rates in randomised trials of induction and maintenance therapy for ulcerative colitis (Review) 
Feagan 2013b (Continued)

\begin{tabular}{|c|c|c|}
\hline Bias & Authors' judgement & Support for judgement \\
\hline $\begin{array}{l}\text { Random sequence generation (selection } \\
\text { bias) }\end{array}$ & Low risk & $\begin{array}{l}\text { Patients were randomly assigned in a } 3: 2 \\
\text { ratio using computer-generated randomi- } \\
\text { sation schedules }\end{array}$ \\
\hline Allocation concealment (selection bias) & Low risk & Centralised allocation \\
\hline $\begin{array}{l}\text { Blinding of participants and personnel } \\
\text { (performance bias) } \\
\text { All outcomes }\end{array}$ & Low risk & $\begin{array}{l}\text { Double-blind study; both the participant } \\
\text { and physician were blinded to the treat- } \\
\text { ment administered }\end{array}$ \\
\hline $\begin{array}{l}\text { Blinding of outcome assessment (detection } \\
\text { bias) } \\
\text { All outcomes }\end{array}$ & Unclear risk & Not described \\
\hline $\begin{array}{l}\text { Incomplete outcome data (attrition bias) } \\
\text { All outcomes }\end{array}$ & Low risk & $\begin{array}{l}\text { The number of subjects who withdrew dur- } \\
\text { ing the induction phase were } 14 \text { and } 7 \text { in } \\
\text { the placebo and vedolizumab groups re- } \\
\text { spectively } \\
\text { Analyses were conducted according to the } \\
\text { ITT principle }\end{array}$ \\
\hline Selective reporting (reporting bias) & Low risk & All expected outcomes were reported \\
\hline Other bias & Low risk & $\begin{array}{l}\text { The study appears to be free of other } \\
\text { sources of bias }\end{array}$ \\
\hline
\end{tabular}

Hanauer 2000

\begin{tabular}{ll}
\hline Methods & Multicenter randomised double-blind placebo-controlled trial $(\mathrm{N}=65)$ \\
\hline Participants & $\begin{array}{l}\text { Patients }>18 \text { years with UC who were in clinical and endoscopic remission } \\
\text { Patients had a history of UC limited to rectum }(15 \mathrm{~cm}) \text { by previous endoscopic exami- } \\
\text { nation, evidence of clinical and endoscopic remission at entry } \\
\text { Use of concomitant medication was prohibited during the trial }\end{array}$ \\
\hline Interventions & $\begin{array}{l}\text { Group } 1: 5 \text {-ASA rectal suppository } 0.5 \mathrm{~g} \text { once daily }(\mathrm{n}=31) \\
\text { Group 2: matched placebo }(\mathrm{n}=34) \\
\text { Groups received treatment for } 24 \text { months }\end{array}$ \\
\hline Outcomes & $\begin{array}{l}\text { Primary outcome: time to relapse (Relapse was defined as symptoms of rectal bleeding } \\
\text { or increase in stool frequency for }>1 \text { week and endoscopic evidence of inflammation on } \\
\text { the individual DAI scales) } \\
\text { Secondary outcomes: adverse events }\end{array}$ \\
\hline
\end{tabular}

Notes

Placebo response and remission rates in randomised trials of induction and maintenance therapy for ulcerative colitis (Review) 
Hanauer 2000 (Continued)

\section{Risk of bias}

\begin{tabular}{|c|c|c|}
\hline Bias & Authors' judgement & Support for judgement \\
\hline $\begin{array}{l}\text { Random sequence generation (selection } \\
\text { bias) }\end{array}$ & Unclear risk & Not described \\
\hline Allocation concealment (selection bias) & Unclear risk & Not described \\
\hline $\begin{array}{l}\text { Blinding of participants and personnel } \\
\text { (performance bias) } \\
\text { All outcomes }\end{array}$ & Low risk & $\begin{array}{l}\text { Not described beyond 'placebo identical to } \\
\text { study medication' }\end{array}$ \\
\hline $\begin{array}{l}\text { Blinding of outcome assessment (detection } \\
\text { bias) } \\
\text { All outcomes }\end{array}$ & Unclear risk & Not described \\
\hline $\begin{array}{l}\text { Incomplete outcome data (attrition bias) } \\
\text { All outcomes }\end{array}$ & Low risk & $\begin{array}{l}\text { Drop-outs balanced across intervention } \\
\text { groups with similar reasons for withdrawal }\end{array}$ \\
\hline Selective reporting (reporting bias) & Low risk & All expected outcomes were reported \\
\hline Other bias & Low risk & $\begin{array}{l}\text { The study appears to be free of other } \\
\text { sources of bias }\end{array}$ \\
\hline
\end{tabular}

Jiang 2015

Methods

Participants

Interventions
Randomised, double-blind, placebo-controlled, and single-centre study ( $\mathrm{N}=123)$

Patients with moderate to severe, treatment refractory, active UC

Group 1: IV infliximab $3.5 \mathrm{mg} / \mathrm{kg}(\mathrm{n}=41)$

Group 2: IV infliximab $5 \mathrm{mg} / \mathrm{kg}(\mathrm{n}=41)$

Group 3: placebo $(\mathrm{n}=41)$

Treatment administered at weeks 0,2 , and 6 and then every 8 weeks through week 22

Patients were followed up for 30 weeks

Primary outcome: clinical response

Secondary outcomes: clinical remission, mucosal healing

Notes

\section{Risk of bias}

Bias

Authors' judgement

Support for judgement 
Jiang 2015 (Continued)

\begin{tabular}{l|lll}
\hline $\begin{array}{l}\text { Random sequence generation (selection } \\
\text { bias) }\end{array}$ & Low risk & Central randomisation performed \\
\hline $\begin{array}{l}\text { Allocation concealment (selection bias) } \\
\begin{array}{l}\text { Blinding of participants and personnel } \\
\text { (performance bias) }\end{array}\end{array}$ & Lnclear risk & Dynamic allocation \\
\hline $\begin{array}{l}\text { All outcomes } \\
\text { Blinding of outcome assessment (detection } \\
\text { bias) } \\
\text { All outcomes }\end{array}$ & Unclear risk & Not described beyond 'double-blind' \\
\hline $\begin{array}{l}\text { Incomplete outcome data (attrition bias) } \\
\text { All outcomes }\end{array}$ & Low risk & Not described \\
\hline $\begin{array}{l}\text { Selective reporting (reporting bias) } \\
\text { Other bias }\end{array}$ & Low risk & Low risk & $\begin{array}{l}\text { Drop-outs balanced } \\
\text { groups with similar reasons for withdrawal }\end{array}$ \\
\hline
\end{tabular}

Kamm 2007

Methods

Randomised, phase III, double-blind, double-dummy, parallel-group, placebo-controlled, multicenter study $(\mathrm{N}=343)$

Participants

Adult patients (> 18 years) with active, mild-to-moderate UC who had recently been diagnosed or relapsed

Patients had a modified UCDAI score between 4-10, with a sigmoidoscopy score $>1$ and a PGA score $<2$

During the screening period, patients could continue taking a stable dose of mesalamine $(52.0 \mathrm{~g} /$ day $)$, but mesalamine was withdrawn at baseline if the patient was eligible for inclusion

Interventions

Group 1: MMX mesalamine $2.4 \mathrm{~g} /$ day $(\mathrm{n}=86)$

Group 2: MMX mesalamine $4.8 \mathrm{~g} /$ day $(\mathrm{n}=85)$

Group 3: Asacol $2.4 \mathrm{~g} /$ day $(\mathrm{n}=86)$

Group 4: Placebo $(\mathrm{n}=86)$

Treatment administered for 8 weeks

All patients received 4 tablets and 2 capsules in the morning, 2 capsules at lunchtime, and 2 capsules in the evening

Outcomes

Primary outcome: proportion of patients in clinical and endoscopic remission Secondary outcomes: clinical remission, clinical improvement, changes in modified UCDAI score, changes in sigmoidoscopic (mucosal) appearance (baseline to week 8), changes in rectal bleeding and stool frequency (from baseline to any study visit), treatment failure rate, and time to withdrawal

Placebo response and remission rates in randomised trials of induction and maintenance therapy for ulcerative colitis (Review) 
Kamm 2007 (Continued)

Notes

Risk of bias

\begin{tabular}{|c|c|c|}
\hline Bias & Authors' judgement & Support for judgement \\
\hline $\begin{array}{l}\text { Random sequence generation (selection } \\
\text { bias) }\end{array}$ & Unclear risk & Not described \\
\hline Allocation concealment (selection bias) & Low risk & $\begin{array}{l}\text { Patients were randomised centrally via an } \\
\text { interactive voice response system }\end{array}$ \\
\hline $\begin{array}{l}\text { Blinding of participants and personnel } \\
\text { (performance bias) } \\
\text { All outcomes }\end{array}$ & Low risk & $\begin{array}{l}\text { Asacol tablets contained } 400 \mathrm{mg} \\
\text { mesalamine and were enclosed in a capsule } \\
\text { for blinding purposes } \\
\text { Double-dummy design: all patients re- } \\
\text { ceived } 4 \text { tablets and } 2 \text { capsules in the morn- } \\
\text { ing, } 2 \text { capsules at lunchtime, and } 2 \text { capsules } \\
\text { in the evening }\end{array}$ \\
\hline $\begin{array}{l}\text { Blinding of outcome assessment (detection } \\
\text { bias) } \\
\text { All outcomes }\end{array}$ & Unclear risk & Not described \\
\hline $\begin{array}{l}\text { Incomplete outcome data (attrition bias) } \\
\text { All outcomes }\end{array}$ & Low risk & $\begin{array}{l}\text { Drop-outs were balanced across interven- } \\
\text { tion groups with similar reasons for with- } \\
\text { drawal } \\
52 / 86 \text { patients in the placebo group, } 70 / 86 \\
\text { patients in the MMX } 2.4 \mathrm{~g} \text { group, } 72 / 85 \\
\text { patients in the MMX } 4.8 \mathrm{~g} \text { group, and } 70 / \\
86 \text { patients in the Asacol group completed } \\
\text { the study } \\
\text { All analyses were performed according to } \\
\text { the ITT principle }\end{array}$ \\
\hline Selective reporting (reporting bias) & Low risk & All expected outcomes were reported \\
\hline Other bias & Low risk & $\begin{array}{l}\text { The study appears to be free of other } \\
\text { sources of bias }\end{array}$ \\
\hline
\end{tabular}

Leiper 2011

Methods

Participants
Randomised, double-blind, placebo-controlled trial $(\mathrm{N}=24)$

Patients > 18 years of age with active steroid-resistant UC (MCS: 6-12 points, failure to respond to at least 2 weeks of $40 \mathrm{mg} /$ day of prednisolone) 
Leiper 2011 (Continued)

\begin{tabular}{|c|c|c|}
\hline Interventions & \multicolumn{2}{|c|}{ Patients received either an infusion of $1 \mathrm{~g}$ rituximab or placebo on day 1 and at 2 weeks } \\
\hline Outcomes & \multicolumn{2}{|c|}{$\begin{array}{l}\text { Primary outcome: clinical remission at week } 4 \\
\text { Secondary outcomes: clinical response at weeks } 4 \text { and } 8 \text {, remission at weeks } 8 \text { and 12, } \\
\text { mucosal healing at weeks } 4 \text { and 12, and improvement in the IBDQ }\end{array}$} \\
\hline Notes & \multicolumn{2}{|c|}{ This drug was not shown to be an effective therapy for active steroid-resistant UC } \\
\hline \multicolumn{3}{|l|}{ Risk of bias } \\
\hline Bias & Authors' judgement & Support for judgement \\
\hline $\begin{array}{l}\text { Random sequence generation (selection } \\
\text { bias) }\end{array}$ & Low risk & $\begin{array}{l}\text { Patients were randomised in a } 2: 1 \text { (treat- } \\
\text { ment:placebo) ratio in blocks of } 5 \text { by the } \\
\text { hospital pharmacy department; the phar- } \\
\text { macists had no other involvement in the } \\
\text { trial }\end{array}$ \\
\hline Allocation concealment (selection bias) & Low risk & $\begin{array}{l}\text { Allocation was concealed from patients and } \\
\text { investigators }\end{array}$ \\
\hline $\begin{array}{l}\text { Blinding of participants and personnel } \\
\text { (performance bias) } \\
\text { All outcomes }\end{array}$ & Low risk & $\begin{array}{l}\text { Allocation was not revealed until the last } \\
\text { patient completed the trial }\end{array}$ \\
\hline $\begin{array}{l}\text { Blinding of outcome assessment (detection } \\
\text { bias) } \\
\text { All outcomes }\end{array}$ & Low risk & $\begin{array}{l}\text { Assessment of response or remission was } \\
\text { made before unblinding }\end{array}$ \\
\hline $\begin{array}{l}\text { Incomplete outcome data (attrition bias) } \\
\text { All outcomes }\end{array}$ & High risk & $\begin{array}{l}\text { There was a high drop-out rate in both } \\
\text { groups } \\
6 / 16 \text { patients in the rituximab group and } 2 / \\
8 \text { patients in the placebo group completed } \\
\text { the } 12 \text { week study } \\
\text { Last value was carried forward for analyses }\end{array}$ \\
\hline Selective reporting (reporting bias) & Low risk & All expected outcomes were reported \\
\hline Other bias & Low risk & $\begin{array}{l}\text { The study appears to be free of other } \\
\text { sources of bias }\end{array}$ \\
\hline
\end{tabular}

Placebo response and remission rates in randomised trials of induction and maintenance therapy for ulcerative colitis (Review) 
Methods

Participants
Randomised, double-blind, placebo-controlled, multicenter clinical trial comparing rosiglitazone to placebo $(\mathrm{N}=105)$

Adult patients with mild-to-moderately active UC (as defined by a modified Mayo score between 4-10)

Eligible patients had been treated with mesalamine $>2000 \mathrm{mg} /$ day for at least 4 weeks or had a documented intolerance to such therapy

Concomitant treatment with corticosteroids was permitted if the dose was stable for a minimum of 4 weeks prior to randomisation and did not exceed prednisone $20 \mathrm{mg} / \mathrm{day}$, budesonide $9 \mathrm{mg} /$ day, or equivalent

Concomitant therapy with AZA or 6-MP was permitted if used for a minimum of 4 months and at a stable dose for a minimum of 2 months prior to randomisation
Group 1: rosiglitazone $4 \mathrm{mg}(\mathrm{n}=52)$

Group 2: placebo $(\mathrm{n}=53)$

Treatment taken orally twice daily for 12 weeks

\section{Risk of bias}

\begin{tabular}{l|l|l}
\hline Bias & Authors judgement & Support for judgement \\
\hline $\begin{array}{l}\text { Random sequence generation (selection } \\
\text { bias) }\end{array}$ & Low risk & $\begin{array}{l}\text { Computer-generated, permuted block ran- } \\
\text { domisation }\end{array}$ \\
\hline Allocation concealment (selection bias) & Low risk & $\begin{array}{l}\text { Centralised randomisation by Data Coor- } \\
\text { dinating Center at the University of Penn- } \\
\text { sylvania } \\
\text { Each site was provided with a randomi- } \\
\text { sation list and treatment packs; treatment } \\
\text { packs were assigned sequentially at each site } \\
\text { according to the list }\end{array}$ \\
\hline
\end{tabular}

Blinding of participants and personnel Unclear risk (performance bias)

All outcomes
Not described

\section{Not described}

Blinding of outcome assessment (detection Unclear risk bias)

All outcomes

Incomplete outcome data (attrition bias) Low risk All outcomes
20 patients in the placebo group and 10 patients in the treatment group dropped out before week 12 
Lewis 2008 (Continued)

\begin{tabular}{l|l|l}
\hline Selective reporting (reporting bias) & Low risk & All expected outcomes were reported \\
\hline Other bias & Low risk & $\begin{array}{l}\text { The study appears to be free of other } \\
\text { sources of bias }\end{array}$ \\
\hline
\end{tabular}

Lichtenstein 2007

Methods

Participants

Interventions

M M

Outcomes

Notes

\section{Risk of bias}

\begin{tabular}{l|ll}
\hline Bias & Authors' judgement & Support for judgement \\
\hline $\begin{array}{l}\text { Random sequence generation (selection } \\
\text { bias) }\end{array}$ & Low risk & $\begin{array}{l}\text { Patients were randomised centrally via an } \\
\text { interactive voice response system }\end{array}$ \\
\hline $\begin{array}{l}\text { Allocation concealment (selection bias) } \\
\text { Blinding of participants and personnel } \\
\text { (performance bias) } \\
\text { All outcomes }\end{array}$ & Low risk & Centralised randomisation \\
\hline $\begin{array}{l}\text { Blinding of outcome assessment (detection } \\
\text { bias) } \\
\text { All outcomes }\end{array}$ & Unclear risk & $\begin{array}{l}\text { To ensure that the study was blinded, allo- } \\
\text { cation of active drug and placebo was con- } \\
\text { cealed }\end{array}$ \\
\hline
\end{tabular}

Phase III, multicenter, double-blind, parallel-group study in patients with mild-to-moderately active $\mathrm{UC}(\mathrm{N}=280)$

Patients $>18$ years with newly diagnosed or relapsing (relapsed 6 weeks before baseline) , mild-to-moderately active UC (UCDAI score of 4-10) with a sigmoidoscopy score $>1$ and a PGA score $>2$ with compatible histology

Placebo ( $\mathrm{n}=93)$, MMX mesalamine $2.4 \mathrm{~g} /$ day $(\mathrm{n}=93)(1.2 \mathrm{~g}$ given twice daily), or MMX mesalamine $4.8 \mathrm{~g} /$ day $(\mathrm{n}=94)$ given once daily $(1: 1: 1)$

Primary outcome: clinical and endoscopic remission (defined as a modified UCDAI score of 1 , with a score of 0 for rectal bleeding and stool frequency, no mucosal friability, and $>1$ point reduction from baseline for sigmoidoscopic score)

Secondary outcomes: remission rates (clinical and endoscopic combined) at week 8, clinical improvement rates, clinical remission rates, change in the total modified UCDAI score from baseline to week 8 , change in symptoms (rectal bleeding and stool frequency) , change in sigmoidoscopic (mucosal) appearance from baseline to week 8 , time to withdrawal, treatment failures, adverse events, laboratory testing (hematology, biochemistry, and urinalysis), physical examination, vital signs and compliance 
Lichtenstein 2007 (Continued)

\begin{tabular}{|c|c|c|}
\hline $\begin{array}{l}\text { Incomplete outcome data (attrition bias) } \\
\text { All outcomes }\end{array}$ & Low risk & $\begin{array}{l}\text { Withdrawals were highest in the placebo } \\
\text { group, primarily due to lack of efficacy ( } 41 / \\
93 \text { in the placebo group, } 17 / 93 \text { in the } 2 . \\
4 \text { g/day group and } 21 / 94 \text { in the } 4.8 \text { g/day } \\
\text { group) }\end{array}$ \\
\hline Selective reporting (reporting bias) & Low risk & All expected outcomes reported \\
\hline Other bias & Low risk & $\begin{array}{l}\text { The study appears to be free of other } \\
\text { sources of bias }\end{array}$ \\
\hline
\end{tabular}

\section{Lichtenstein 2010}

Methods

Participants

Interventions

Outcomes
Multicenter, randomised, double-blind, placebo-controlled trial $(\mathrm{N}=305)$

Adult patients $>18$ years with UC in remission (defined as rectal bleeding $=0$ and mucosal appearance $<2$ using the revised Sutherland Disease Activity Index)

Mesalamine granules (Apriso) $1.5 \mathrm{~g} /$ day dosed once daily $(\mathrm{n}=209)$ or placebo $(\mathrm{n}=96)$ for 6 months

Primary outcome: percentage of patients who were relapse free at 6 months Secondary outcomes: percentages of patients with a level of change from baseline in rectal bleeding score, mucosal appearance score, PGA and stool frequency at months 1,3 , and 6 and end of treatment; percentage of patients classified as treatment success, relapse-free duration, and adverse events

Notes

\section{Risk of bias}

\begin{tabular}{l|l|l} 
Bias & Authors' judgement & Support for judgement \\
\hline $\begin{array}{l}\text { Random sequence generation (selection } \\
\text { bias) }\end{array}$ & Low risk & $\begin{array}{l}\text { Patients were assigned a unique treatment } \\
\text { ID number via a randomisation schedule }\end{array}$ \\
\hline $\begin{array}{l}\text { Allocation concealment (selection bias) } \\
\text { Blinding of participants and personnel } \\
\text { (performance bias) } \\
\text { All outcomes }\end{array}$ & Low risk & Not described \\
\hline $\begin{array}{l}\text { Blinding of outcome assessment (detection } \\
\text { bias) } \\
\text { All outcomes }\end{array}$ & Low risk & $\begin{array}{l}\text { The study was double-blind with a } \\
\text { matched placebo }\end{array}$ \\
\hline
\end{tabular}


Lichtenstein 2010 (Continued)

\begin{tabular}{lll}
\hline $\begin{array}{l}\text { Incomplete outcome data (attrition bias) } \\
\text { All outcomes }\end{array}$ & Low risk & $\begin{array}{l}\text { Drop-outs balanced across intervention } \\
\text { groups with similar reasons for withdrawal }\end{array}$ \\
\hline Selective reporting (reporting bias) & Low risk & All expected outcomes were reported \\
\hline Other bias & Low risk & $\begin{array}{l}\text { The study appears to be free of other } \\
\text { sources of bias }\end{array}$ \\
\hline
\end{tabular}

Marteau 2005

\begin{tabular}{ll}
\hline Methods & $\begin{array}{l}\text { Randomised, double-blind, multinational, randomised, parallel-group, placebo-con- } \\
\text { trolled study }(\mathrm{N}=127)\end{array}$ \\
\hline Participants & $\begin{array}{l}\text { Adult patients }>18 \text { years with previously diagnosed mild-to-moderate UC (UCDAI } \\
\text { score 3-8) }\end{array}$ \\
\hline Interventions & $\begin{array}{l}\text { Group 1: oral mesalazine } 4 \mathrm{~g} / \text { day }+ \text { mesalazine } 1 \mathrm{~g} \text { enema }(\mathrm{n}=71) \\
\text { Group } 2: \text { oral mesalazine } 4 \mathrm{~g} / \text { day }+ \text { placebo enema }(\mathrm{n}=56)\end{array}$ \\
\hline Outcomes & $\begin{array}{l}\text { Primary outcome: remission rates at week } 4 \text { based on UCDAI score } \\
\text { Secondary outcomes: remission rates at week } 8, \text { improvement rates at weeks } 4 \text { and } 8, \\
\text { time to cessation of rectal bleeding, adverse events, laboratory tests at weeks } 4 \text { and } 8 \\
\text { (serum creatinine, liver enzymes, platelets, white blood count, red blood count, and } \\
\text { urinary tests for protein and haemoglobin) }\end{array}$ \\
\hline Notes & \\
\hline
\end{tabular}

Risk of bias

\begin{tabular}{|c|c|c|}
\hline Bias & Authors' judgement & Support for judgement \\
\hline $\begin{array}{l}\text { Random sequence generation (selection } \\
\text { bias) }\end{array}$ & Unclear risk & Not described \\
\hline Allocation concealment (selection bias) & Unclear risk & Not described \\
\hline $\begin{array}{l}\text { Blinding of participants and personnel } \\
\text { (performance bias) } \\
\text { All outcomes }\end{array}$ & Unclear risk & Not described \\
\hline $\begin{array}{l}\text { Blinding of outcome assessment (detection } \\
\text { bias) } \\
\text { All outcomes }\end{array}$ & Unclear risk & Not described \\
\hline $\begin{array}{l}\text { Incomplete outcome data (attrition bias) } \\
\text { All outcomes }\end{array}$ & Low risk & $\begin{array}{l}\text { Drop-outs balanced across groups with } \\
\text { similar reasons for withdrawal }(58 / 71 \text { pa- } \\
\text { tients in the mesalazine enema group and } \\
40 / 56 \text { patients in the placebo group com- }\end{array}$ \\
\hline
\end{tabular}

Placebo response and remission rates in randomised trials of induction and maintenance therapy for ulcerative colitis (Review) 
Marteau 2005 (Continued)

pleted week 8)

\begin{tabular}{|c|c|c|}
\hline Selective reporting (reporting bias) & Low risk & All expected outcomes were reported \\
\hline Other bias & Low risk & $\begin{array}{l}\text { The study appears to be free of other } \\
\text { sources of bias }\end{array}$ \\
\hline
\end{tabular}

Mayer 2014

\begin{tabular}{ll}
\hline Methods & $\begin{array}{l}\text { 8-week, phase II, double-blind, placebo-controlled, randomised, multi-centre study (N } \\
=109)\end{array}$ \\
\hline Participants & $\begin{array}{l}\text { Adult patients }>18 \text { years with an active UC disease flare (defined as a MCS 6-10 with a } \\
\text { endoscopic subscore of }>2)\end{array}$ \\
\hline Interventions & $\begin{array}{l}\text { Group 1: IV BMS-936557 } 10 \mathrm{mg} / \mathrm{kg}(\mathrm{n}=55) \\
\text { Group 2: placebo }(\mathrm{n}=54) \\
\text { Treatment administered at weeks } 0,2,4 \text { and } 6 \\
\text { Oral 5-ASA, prednisolone } 20 \mathrm{mg} / \text { day, AZA and 6-MP were continued at stable doses } \\
\text { during the study }\end{array}$ \\
\hline Outcomes & $\begin{array}{l}\text { Primary outcome: rate of clinical response at day 57 } \\
\text { Secondary outcomes: clinical remission and mucosal healing }\end{array}$ \\
\hline Notes & \\
\hline
\end{tabular}

\section{Risk of bias}

\begin{tabular}{l|l|l} 
Bias & Authors' judgement & Support for judgement \\
\hline $\begin{array}{l}\text { Random sequence generation (selection } \\
\text { bias) }\end{array}$ & Unclear risk & Not described \\
\hline $\begin{array}{l}\text { Allocation concealment (selection bias) } \\
\begin{array}{l}\text { Blinding of participants and personnel } \\
\text { (performance bias) }\end{array}\end{array}$ & Low risk & Low risk \\
$\begin{array}{l}\text { All outcomes } \\
\text { using dynamic treatment allocation }\end{array}$ \\
\hline $\begin{array}{l}\text { Blinding of outcome assessment (detection } \\
\text { bias) } \\
\text { All outcomes }\end{array}$ & Unclear risk & $\begin{array}{l}\text { Treatment assignment was blinded for per- } \\
\text { sonnel at the study sites and for patients; } \\
\text { the study site pharmacist/designated nurse } \\
\text { was unblinded for study drug preparation }\end{array}$ \\
\hline
\end{tabular}

Incomplete outcome data (attrition bias) Low risk All outcomes
Drop-outs were balanced across groups with similar reasons for withdrawal 
Mayer 2014 (Continued)

\begin{tabular}{|c|c|c|}
\hline Selective reporting (reporting bias) & Low risk & All expected outcomes were reported \\
\hline Other bias & Low risk & $\begin{array}{l}\text { The study appears to be free of other } \\
\text { sources of bias }\end{array}$ \\
\hline
\end{tabular}

Nikolaus 2003

Methods

Participants

Interventions

Outcomes

Notes

\section{Risk of bias}

\section{Bias}

Authors' judgement

Primary outcomes: response (decrease of at least 3 points from baseline in the UCDAI symptoms score and PGA (without the proctosigmoidoscopic score)); and remission (complete resolution of clinical symptoms (all clinical UCSS subscores $=0$ ) with a proctosigmoidoscopy score of 0 or 1 at any time during treatment

Secondary outcomes: overall treatment and endpoint responses, clinical endpoint responses, safety data

Group 1: IFN- $\beta$ b-1a SC injection 3 times a week at variable doses for a variable duration of treatment $(\mathrm{n}=10)$

Group 2: placebo $(\mathrm{n}=7)$

Minimum treatment duration $=4$ weeks; maximum treatment duration $=8$ weeks

If improvement was observed after six injections at any dose, the patient entered a maintenance treatment phase of 6-12 injections at that dose

If no improvement after six injections or if remission occurred at any point, treatment was stopped
Random sequence generation (selection Low risk bias)

Allocation concealment (selection bias) Low risk

Blinding of participants and personnel Unclear risk (performance bias)

All outcomes
Centralised randomisation by Corporate Biometrics Department of Serono International SA

Randomisation was performed using a computer generated list and stratified by centre with block size of 3 (2:1 IFN- $\beta$-1a: placebo)

Not described 
Nikolaus 2003 (Continued)

\begin{tabular}{|c|c|c|}
\hline $\begin{array}{l}\text { Blinding of outcome assessment (detection } \\
\text { bias) } \\
\text { All outcomes }\end{array}$ & Unclear risk & Not described \\
\hline $\begin{array}{l}\text { Incomplete outcome data (attrition bias) } \\
\text { All outcomes }\end{array}$ & Low risk & $\begin{array}{l}\text { One patient was excluded a priori due to } \\
\text { mis-allocation of study drug } 6 / 10(60 \%) \\
\text { of patients in the IFN- } \beta \text {-1a group and } 2 / \\
7(28.6 \%) \text { of patients in the control group } \\
\text { stopped treatment early }\end{array}$ \\
\hline Selective reporting (reporting bias) & Low risk & All expected outcomes were reported \\
\hline Other bias & Low risk & $\begin{array}{l}\text { The study appears to be free of other } \\
\text { sources of bias }\end{array}$ \\
\hline
\end{tabular}

Ogata 2006

Methods

Participants

Interventions
Double-blind, randomised, placebo-controlled trial $(\mathrm{N}=63)$

Adult patients $>18$ years with refractory, moderate to severely active UC

Group 1: low trough concentration $(5-10 \mathrm{ng} / \mathrm{ml})$ oral tacrolimus $(\mathrm{n}=22)$

Group 2: high trough concentration $(10-15 \mathrm{ng} / \mathrm{ml})$ oral tacrolimus $(\mathrm{n}=21)$

Group 3: placebo $(\mathrm{n}=20)$

Blood was taken to assess trough concentration 12-24 hours after initial dose and dosage was adjusted to maintain concentrations within the assigned target range

Primary outcome: proportion of patients with improvement (combination of partial and complete response)

Partial response defined as a reduction of $>4$ points on DAI with improvement in all categories

Complete response was defined as resolution of all symptoms (all scores $=0$ )

Secondary outcomes: changes in DAI subscores from baseline, clinical remission and mucosal healing

Notes

\section{Risk of bias}

\begin{tabular}{l|l|l}
\hline Bias & Authors' judgement & Support for judgement \\
\hline $\begin{array}{l}\text { Random sequence generation (selection } \\
\text { bias) }\end{array}$ & Unclear risk & Not described \\
\hline
\end{tabular}

$\begin{array}{lll}\text { Allocation concealment (selection bias) } & \text { Unclear risk } & \text { Not described }\end{array}$

Placebo response and remission rates in randomised trials of induction and maintenance therapy for ulcerative colitis (Review) 
Ogata 2006 (Continued)

Blinding of participants and personnel Low risk (performance bias)

All outcomes

\begin{tabular}{|c|c|c|}
\hline $\begin{array}{l}\text { Blinding of outcome assessment (detection } \\
\text { bias) } \\
\text { All outcomes }\end{array}$ & Unclear risk & Not described \\
\hline $\begin{array}{l}\text { Incomplete outcome data (attrition bias) } \\
\text { All outcomes }\end{array}$ & Low risk & All 65 patients completed the study \\
\hline Selective reporting (reporting bias) & Low risk & All expected outcomes were reported \\
\hline Other bias & Low risk & $\begin{array}{l}\text { The study appears to be free of other } \\
\text { sources of bias }\end{array}$ \\
\hline
\end{tabular}

Ogata 2012

Methods

Participants

Interventions

Outcomes

Primary outcome: clinical response at 2 weeks (defined by an improvement in all DAI subscores and a reduction in total DAI score by at least 4 points)

Secondary outcomes: mucosal healing and clinical remission
Doses in the placebo group were pseudoadjusted to preserve study blinding sources of bias

\begin{tabular}{l|l|l}
\hline Notes & & \\
\hline Risk of bias & Authors' judgement & Support for judgement \\
\hline Bias & Unclear risk & Not described \\
\hline $\begin{array}{l}\text { Random sequence generation (selection } \\
\text { bias) }\end{array}$ & Low risk & $\begin{array}{l}\text { Centralised randomisation performed by } \\
\text { the Control Center (Bellsystem24, a third- } \\
\text { party organization independent of study } \\
\text { physicians and sponsor) }\end{array}$
\end{tabular}


Ogata 2012 (Continued)

Blinding of participants and personnel Unclear risk (performance bias)

All outcomes

Blinding of outcome assessment (detection Low risk bias)

All outcomes
Not described

To preserve blinding, blood trough levels were measured by SRL (a third-party organization independent of study physicians and sponsor) and relayed to the Control Center (Bellsystem24)

Dosages were calculated at the Control

Center based on the trough levels

Not described

All expected outcomes were reported

The study appears to be free of other sources of bias

\section{Oren 1996}

\begin{tabular}{l|l}
\hline Methods & Randomised, double-blind controlled trial $(\mathrm{N}=67)$ \\
\hline Participants & $\begin{array}{l}\text { Patients with chronic (steroid therapy at }>7.5 \mathrm{mg} / \text { day for at least } 4 \text { months of the } \\
\text { proceeding year), active UC (Mayo clinic score of }>7 \text { at entry) } \\
\text { Disease was diagnosed by clinical, radiographic, endoscopic, and pathological criteria }\end{array}$ \\
\hline Interventions & $\begin{array}{l}\text { Group } 1: \text { oral methotrexate } 2.5 \mathrm{mg} / \mathrm{wk}-2.5 \mathrm{mg} / \mathrm{day}(\mathrm{n}=30) \\
\text { Group } 2: \text { identical placebo }(\mathrm{n}=37)\end{array}$ \\
\hline Outcomes & $\begin{array}{l}\text { Primary outcome: clinical remission }(\mathrm{MCS}<3 \text { and steroid-free) } \\
\text { Secondary outcomes: time to first remission, clinical relapse (increase in the MCS }>3 \\
\text { and/or reintroduction of steroids at a dose of }>300 \mathrm{mg} / \mathrm{month})\end{array}$ \\
\hline Notes & \\
\hline
\end{tabular}

\section{Risk of bias}

\begin{tabular}{l|l|l}
\hline Bias & Authors' judgement & Support for judgement \\
\hline $\begin{array}{l}\text { Random sequence generation (selection } \\
\text { bias) }\end{array}$ & Unclear risk & Not described \\
\hline Allocation concealment (selection bias) & Low risk & $\begin{array}{l}\text { Centralised pharmacy randomisation } \\
\text { Prepackaged coded sets (equal number of } \\
\text { methotrexate or placebo tablets) were de- } \\
\text { livered to each centre }\end{array}$ \\
\hline
\end{tabular}

Placebo response and remission rates in randomised trials of induction and maintenance therapy for ulcerative colitis (Review) 
Oren 1996 (Continued)

\begin{tabular}{|c|c|c|}
\hline $\begin{array}{l}\text { Blinding of participants and personnel } \\
\text { (performance bias) } \\
\text { All outcomes }\end{array}$ & Low risk & $\begin{array}{l}\text { The centralized pharmacist and an un- } \\
\text { blinded observer were the only individuals } \\
\text { with access to the allocation code }\end{array}$ \\
\hline $\begin{array}{l}\text { Blinding of outcome assessment (detection } \\
\text { bias) } \\
\text { All outcomes }\end{array}$ & Unclear risk & Not described \\
\hline $\begin{array}{l}\text { Incomplete outcome data (attrition bias) } \\
\text { All outcomes }\end{array}$ & Low risk & $\begin{array}{l}2 / 30 \text { patients in the methotrexate group } \\
\text { dropped out; } 9 / 37 \text { patients in the placebo } \\
\text { group dropped out } \\
\text { ITT principle was used for analyses }\end{array}$ \\
\hline Selective reporting (reporting bias) & Low risk & All expected outcomes were reported \\
\hline Other bias & Low risk & $\begin{array}{l}\text { The study appears to be free of other } \\
\text { sources of bias }\end{array}$ \\
\hline
\end{tabular}

Probert 2003

Methods

Participants
Double-blind, randomised, placebo controlled trial $(\mathrm{N}=43)$

Adult patients $>18$ years with UC who had failed to respond to glucocorticoid treatment (at least $30 \mathrm{mg}$ prednisolone a week, or equivalent) and were not in need of urgent colectomy

At screening, all patients were required to have UCDAI $>6$ and a sigmoidoscopy score $>2$ on the Baron scale

Interventions

Group 1: IV infliximab $(5 \mathrm{mg} / \mathrm{kg})$ at weeks 0 and $2(\mathrm{n}=23)$

Group 2: placebo at weeks 0 and $2(\mathrm{n}=20)$

Outcomes

Primary outcome: clinical remission (defined as UCCS $<2$ ) at 6 weeks

Secondary outcomes: sigmoidoscopic remission (defined as a Baron's score of 0 ) at 6 weeks, quality of life

Notes

Author provided further verbal information on allocation concealment

\section{Risk of bias}

\begin{tabular}{l|l|l}
\hline Bias & Authors' judgement & Support for judgement \\
\hline $\begin{array}{l}\text { Random sequence generation (selection } \\
\text { bias) }\end{array}$ & Low risk & Block randomisation \\
\hline Allocation concealment (selection bias) & Low risk & $\begin{array}{l}\text { Centralised randomisation performed by } \\
\text { Schering-Plough } \\
\text { Author confirmed adequate allocation con- } \\
\text { cealment }\end{array}$ \\
\hline
\end{tabular}


Probert 2003 (Continued)

Blinding of participants and personnel Low risk

Pharmacists, investigators and participants (performance bias)

were blinded to the treatment administered

All outcomes

\begin{tabular}{|c|c|c|}
\hline $\begin{array}{l}\text { Blinding of outcome assessment (detection } \\
\text { bias) } \\
\text { All outcomes }\end{array}$ & Unclear risk & Not described \\
\hline $\begin{array}{l}\text { Incomplete outcome data (attrition bias) } \\
\text { All outcomes }\end{array}$ & Low risk & $\begin{array}{l}\text { All patients completed the } 6 \text { week study } \\
\text { and all results reported }\end{array}$ \\
\hline Selective reporting (reporting bias) & Low risk & All expected outcomes were reported \\
\hline Other bias & Low risk & $\begin{array}{l}\text { The study appears to be free of other } \\
\text { sources of bias }\end{array}$ \\
\hline
\end{tabular}

\section{Reinisch 2011}

\begin{tabular}{ll}
\hline Methods & Randomised, placebo-controlled, double-blind study $(\mathrm{N}=390)$ \\
\hline Participants & $\begin{array}{l}\text { Non-hosptialized, adult patients with moderately to severely active UC (Mayo score }>6 \\
\text { points and endoscopic subscore }>2 \text { points) despite treatment with corticosteroids and/ } \\
\text { or immunosuppressants }\end{array}$ \\
\hline Interventions & $\begin{array}{l}\text { Group 1: adalimumab } 160 \mathrm{mg} \text { at week } 0,80 \mathrm{mg} \text { at week 2, } 40 \text { mg at weeks } 4 \text { and } 6 \text { (n } \\
=130) \\
\text { Group 2: adalimumab } 80 \mathrm{mg} \text { at week } 0,40 \mathrm{mg} \text { at weeks 2, } 4 \text { and } 6 \text { (n }=130) \\
\text { Group 3: placebo }(\mathrm{n}=130)\end{array}$ \\
\hline
\end{tabular}

\begin{tabular}{|c|c|}
\hline Outcomes & $\begin{array}{l}\text { Primary outcome: clinical remission (MCS }<2 \text { with no individual subscore }>1 \text { ) at week } \\
8 \\
\text { Secondary outcomes: clinical response }(>3 \text { point decrease in MCS and greater than or } \\
\text { equal to } 30 \% \text { from baseline plus a decrease in rectal bleeding subscore }>1 \text { or an absolute } \\
\text { rectal bleeding subscore of } 0 \text { or } 1 \text { ), mucosal healing, adverse events }\end{array}$ \\
\hline
\end{tabular}

Notes

The original study protocol described SC adalimumab $160 \mathrm{mg}$ at week $0,80 \mathrm{mg}$ at week 2, $40 \mathrm{mg}$ at weeks 4 and 6 or placebo

The protocol was amended at the request of the European regulatory authorities

\section{Risk of bias}

\begin{tabular}{|c|c|c|}
\hline Bias & Authors' judgement & Support for judgement \\
\hline $\begin{array}{l}\text { Random sequence generation (selection } \\
\text { bias) }\end{array}$ & Low risk & Computer-generated randomisation \\
\hline
\end{tabular}




\section{Reinisch 2011 (Continued)}

\begin{tabular}{|c|c|c|}
\hline Allocation concealment (selection bias) & Low risk & $\begin{array}{l}\text { Centralised randomisation performed by } \\
\text { the study sponsor }\end{array}$ \\
\hline $\begin{array}{l}\text { Blinding of participants and personnel } \\
\text { (performance bias) } \\
\text { All outcomes }\end{array}$ & Low risk & $\begin{array}{l}\text { Patients, study site personnel, study investi- } \\
\text { gators, and the study sponsor were blinded } \\
\text { to treatment assignment throughout the } \\
\text { study; patients in the placebo group re- } \\
\text { ceived the same number of injections as pa- } \\
\text { tients in the adalimumab treatment group } \\
\text { (s) }\end{array}$ \\
\hline $\begin{array}{l}\text { Blinding of outcome assessment (detection } \\
\text { bias) } \\
\text { All outcomes }\end{array}$ & Low risk & $\begin{array}{l}\text { Study site personnel, and study investiga- } \\
\text { tors were blinded to treatment assignment } \\
\text { throughout the study }\end{array}$ \\
\hline $\begin{array}{l}\text { Incomplete outcome data (attrition bias) } \\
\text { All outcomes }\end{array}$ & Low risk & $\begin{array}{l}\text { Drop-outs were balanced across treatment } \\
\text { groups with similar reasons for withdrawal }\end{array}$ \\
\hline Selective reporting (reporting bias) & Low risk & $\begin{array}{l}\text { The study reports primary outcome data } \\
\text { for the amended protocol group only } \\
\text { Patients enrolled before the amendment } \\
\text { were not included in the primary analysis } \\
\text { data set }\end{array}$ \\
\hline Other bias & Unclear risk & $\begin{array}{l}\text { The study appears to be free of other } \\
\text { sources of bias }\end{array}$ \\
\hline
\end{tabular}

Reinisch 2015

\begin{tabular}{|c|c|}
\hline Methods & Randomised, double-blind, multi-center placebo-controlled study $(\mathrm{N}=84)$ \\
\hline Participants & $\begin{array}{l}\text { Male and female patients aged } 18-65 \text { with } \mathrm{UC} \text { as confirmed by histopathology as well } \\
\text { as active disease defined by a Mayo score } \geq 4 \text { and }<10 \text { with an endoscopic subscore of } \\
\geq 2 \text { points and fecal calprotectin } \geq 100 \mathrm{mg} / \mathrm{kg}\end{array}$ \\
\hline Interventions & $\begin{array}{l}\text { Group 1: IV Anrukinzumab } 200 \mathrm{mg}(\mathrm{n}=21) \\
\text { Group 2: IV Anrukinzumab } 400 \mathrm{mg}(\mathrm{n}=21) \\
\text { Group 3: IV Anrukinzumab } 600 \mathrm{mg}(\mathrm{n}=21) \\
\text { Group 4: Placebo }(\mathrm{n}=21)\end{array}$ \\
\hline Outcomes & $\begin{array}{l}\text { Primary outcome: Fold change from baseline in fecal calprotectin at week } 14 \\
\text { Secondary outcomes: endpoints included fold change from baseline in fecal calprotectin } \\
\text { at weeks } 2,4,8 \text { and } 12 \text {, pharmacokinetics, total IL-13, antidrug and neutralising anti- } \\
\text { bodies, as well as safety and tolerability of anrukinzumab }\end{array}$ \\
\hline Notes & \\
\hline
\end{tabular}

\section{Risk of bias}

Placebo response and remission rates in randomised trials of induction and maintenance therapy for ulcerative colitis (Review) 
Reinisch 2015 (Continued)

\begin{tabular}{|c|c|c|}
\hline Bias & Authors' judgement & Support for judgement \\
\hline $\begin{array}{l}\text { Random sequence generation (selection } \\
\text { bias) }\end{array}$ & Unclear risk & Not described \\
\hline Allocation concealment (selection bias) & Unclear risk & Not described \\
\hline $\begin{array}{l}\text { Blinding of participants and personnel } \\
\text { (performance bias) } \\
\text { All outcomes }\end{array}$ & Unclear risk & Not described beyond 'double-blind' \\
\hline $\begin{array}{l}\text { Blinding of outcome assessment (detection } \\
\text { bias) } \\
\text { All outcomes }\end{array}$ & Unclear risk & Not described \\
\hline $\begin{array}{l}\text { Incomplete outcome data (attrition bias) } \\
\text { All outcomes }\end{array}$ & Low risk & $\begin{array}{l}\text { Withdrawals were balanced across groups, } \\
\text { with } 10 / 21 \text { patients in the placebo group, } \\
13 / 21 \text { patients in the } 200 \mathrm{mg} \text { group, } 15 / \\
21 \text { patients in the } 400 \mathrm{mg} \text { group and } 7 / 21 \\
\text { patients in the } 600 \mathrm{mg} \text { group completing } \\
\text { treatment }\end{array}$ \\
\hline Selective reporting (reporting bias) & Low risk & All expected outcomes were reported \\
\hline Other bias & Low risk & $\begin{array}{l}\text { The study appears to be free from other } \\
\text { sources of bias }\end{array}$ \\
\hline
\end{tabular}

Rubin 2015

\begin{tabular}{ll}
\hline Methods & Randomised, double-blind, placebo-controlled trial $(\mathrm{N}=510)$ \\
\hline Participants & Patients with mild-to-moderately active UC inadequately controlled with oral 5-ASAs \\
\hline Interventions & $\begin{array}{l}\text { Group 1: Budesonide MMX } 9 \mathrm{mg} \\
\text { Group 2: placebo } \\
\text { Patients received treatment for } 8 \text { weeks in addition to their existing 5-ASA medication }\end{array}$ \\
\hline Outcomes & $\begin{array}{l}\text { Primary outcome: combined clinical and endoscopic remission at week } 8 \\
\text { Secondary outcomes: clinical remission, endoscopic remission and histological healing }\end{array}$ \\
\hline Notes & Reported in abstract form only; not included in quantitative synthesis \\
\hline
\end{tabular}

Risk of bias

\begin{tabular}{l|ll}
\hline Bias & Authors' judgement & Support for judgement \\
\hline $\begin{array}{l}\text { Random sequence generation (selection } \\
\text { bias) }\end{array}$ & Unclear risk & Not described \\
\hline $\begin{array}{l}\text { Placebo response and remission rates in randomised trials of induction and maintenance therapy for ulcerative colitis (Review) } \\
\text { Copyright } \odot 2017 \text { The Cochrane Collaboration. Published by John Wiley \& Sons, Ltd. }\end{array}$
\end{tabular}


Rubin 2015 (Continued)

\begin{tabular}{l|lll}
\hline Allocation concealment (selection bias) & Unclear risk & Not described \\
\hline $\begin{array}{l}\text { Blinding of participants and personnel } \\
\text { (performance bias) } \\
\text { All outcomes }\end{array}$ & Unclear risk & Not described beyond 'double-blind' \\
\hline $\begin{array}{l}\text { Blinding of outcome assessment (detection } \\
\text { bias) } \\
\text { All outcomes }\end{array}$ & Unclear risk & Not described \\
\hline $\begin{array}{l}\text { Incomplete outcome data (attrition bias) } \\
\text { All outcomes }\end{array}$ & Unclear risk & Not described \\
\hline Selective reporting (reporting bias) & Unclear risk & $\begin{array}{c}\text { Two of the secondary outcomes (clinical } \\
\text { remission and endoscopic remission) not } \\
\text { reported on in abstract }\end{array}$ \\
\hline \begin{tabular}{l} 
Other bias \\
\hline
\end{tabular} & Unclear risk & Study reported in abstract form only \\
\hline
\end{tabular}

Rutgeerts 2005a

\begin{tabular}{ll}
\hline Methods & Randomised, double-blind placebo controlled trial $(\mathrm{N}=364)$ (ACT-1) \\
\hline Participants & $\begin{array}{l}\text { Adult ambulatory patients with moderately to severely active UC despite concurrent and } \\
\text { stable treatment with oral corticosteroids and/or immunosuppressives were included } \\
\text { Diagnosis of disease was confirmed by colonoscopy with biopsy }\end{array}$ \\
\hline Interventions & $\begin{array}{l}\text { Group } 1: 10 \mathrm{mg} / \mathrm{kg} \text { infliximab }(\mathrm{n}=122) \\
\text { Group } 2: 5 \mathrm{mg} / \mathrm{kg} \text { infliximab }(\mathrm{n}=121) \\
\text { Group 3: placebo }(\mathrm{n}=121) \\
\text { Patients received treatment at at weeks } 0,2,6,14,22,30,38, \text { and } 46\end{array}$ \\
\hline Outcomes & $\begin{array}{l}\text { Primary outcome: clinical response at week } 8 \\
\text { Secondary outcomes: clinical response or remission with discontinuation of corticos- } \\
\text { teroids at week } 30 \text { in both studies and at week } 54 \text { in ACT-1; clinical remission and } \\
\text { mucosal healing at weeks } 8 \text { and } 30 \text { in both studies and at } \\
\text { week } 54 \text { in ACT-1; and a clinical response at week } 8 \text { in patients with a history of disease } \\
\text { refractory to } \\
\text { corticosteroids }\end{array}$ \\
\hline Notes & Author provided further information on method of randomisation \\
\hline
\end{tabular}

\section{Risk of bias}

\begin{tabular}{|c|c|c|}
\hline Bias & Authors' judgement & Support for judgement \\
\hline $\begin{array}{l}\text { Random sequence generation (selection } \\
\text { bias) }\end{array}$ & Low risk & Computer-generated \\
\hline
\end{tabular}


Rutgeerts 2005a (Continued)

\begin{tabular}{|c|c|c|}
\hline Allocation concealment (selection bias) & Low risk & $\begin{array}{l}\text { Centralised randomisation with a dynamic } \\
\text { treatment allocation stratified according to } \\
\text { the investigational site and whether pa- } \\
\text { tients had corticosteroid refractory disease }\end{array}$ \\
\hline $\begin{array}{l}\text { Blinding of participants and personnel } \\
\text { (performance bias) } \\
\text { All outcomes }\end{array}$ & Unclear risk & Not described \\
\hline $\begin{array}{l}\text { Blinding of outcome assessment (detection } \\
\text { bias) } \\
\text { All outcomes }\end{array}$ & Unclear risk & Not described \\
\hline $\begin{array}{l}\text { Incomplete outcome data (attrition bias) } \\
\text { All outcomes }\end{array}$ & Low risk & $\begin{array}{l}\text { Drop-outs were balanced across treatment } \\
\text { groups with similar reasons for withdrawal }\end{array}$ \\
\hline Selective reporting (reporting bias) & Low risk & All expected outcomes were reported \\
\hline Other bias & Low risk & $\begin{array}{l}\text { The study appears to be free of other } \\
\text { sources of bias }\end{array}$ \\
\hline
\end{tabular}

Rutgeerts 2005b

\begin{tabular}{ll}
\hline Methods & Randomised, double-blind placebo controlled trial $(\mathrm{N}=364)($ ACT-2) \\
\hline Participants & $\begin{array}{l}\text { Adult ambulatory patients with moderately to severely active UC despite concurrent and } \\
\text { stable treatment with oral corticosteroids and/or immunosuppressives were included } \\
\text { Diagnosis of disease was confirmed by colonoscopy with biopsy }\end{array}$ \\
\hline Interventions & $\begin{array}{l}\text { Group } 1: 10 \mathrm{mg} / \mathrm{kg} \text { infliximab }(\mathrm{n}=120) \\
\text { Group } 2: 5 \mathrm{mg} / \mathrm{kg} \text { infliximab }(\mathrm{n}=121) \\
\text { Group 3: placebo }(\mathrm{n}=123) \\
\text { Patients received treatment at weeks } 0,2,6,14, \text { and } 22\end{array}$ \\
\hline Outcomes & $\begin{array}{l}\text { Primary outcome: clinical response at week } 8 \\
\text { Secondary outcomes: clinical response or remission with discontinuation of corticos- } \\
\text { teroids at week } 30 \text { in both studies and at week } 54 \text { in ACT-1; clinical remission and mu- } \\
\text { cosal healing at weeks } 8 \text { and } 30 \text { in both studies and at week } 54 \text { in ACT-1; and a clinical } \\
\text { response at week } 8 \text { in patients with a history of disease refractory to corticosteroids }\end{array}$ \\
\hline Notes & \begin{tabular}{l} 
Author provided further information on method of randomisation \\
\hline of bias
\end{tabular} \\
\hline
\end{tabular}

\section{Bias}

Authors' judgement

Support for judgement

Placebo response and remission rates in randomised trials of induction and maintenance therapy for ulcerative colitis (Review) 
Rutgeerts 2005b (Continued)

\begin{tabular}{|c|c|c|}
\hline $\begin{array}{l}\text { Random sequence generation (selection } \\
\text { bias) }\end{array}$ & Low risk & Computer-generated \\
\hline Allocation concealment (selection bias) & Low risk & $\begin{array}{l}\text { Centralised randomisation with a dynamic } \\
\text { treatment allocation stratified according to } \\
\text { the investigational site and whether pa- } \\
\text { tients had corticosteroid refractory disease }\end{array}$ \\
\hline $\begin{array}{l}\text { Blinding of participants and personnel } \\
\text { (performance bias) } \\
\text { All outcomes }\end{array}$ & Unclear risk & Not described \\
\hline $\begin{array}{l}\text { Blinding of outcome assessment (detection } \\
\text { bias) } \\
\text { All outcomes }\end{array}$ & Unclear risk & Not described \\
\hline $\begin{array}{l}\text { Incomplete outcome data (attrition bias) } \\
\text { All outcomes }\end{array}$ & Low risk & $\begin{array}{l}\text { Drop-outs were balanced across treatment } \\
\text { groups with similar reasons for withdrawal }\end{array}$ \\
\hline Selective reporting (reporting bias) & Low risk & All expected outcomes were reported \\
\hline Other bias & Low risk & $\begin{array}{l}\text { The study appears to be free of other } \\
\text { sources of bias }\end{array}$ \\
\hline
\end{tabular}

\section{Rutgeerts 2013a}

Methods

Randomised, placebo-controlled, double-blind within-cohort study ( $\mathrm{N}=48$ ); single ascending dose stage $(\mathrm{N}=25)$

Participants

Adult patients (18-70 years) with a diagnosis of UC for > 12 weeks and a MCS of $>5$ points at screening

Interventions

In the single ascending dose, 5 groups of patients received etrolizumab or placebo:

Group 1: IV etrolizumab $0.3 \mathrm{mg} / \mathrm{kg}(\mathrm{n}=4)$ or placebo

Group 2: IV etrolizumab $1.0 \mathrm{mg} / \mathrm{kg}(\mathrm{n}=4)$ or placebo

Group 3: IV etrolizumab $3.0 \mathrm{mg} / \mathrm{kg}(\mathrm{n}=4)$ or placebo

Group 4: IV etrolizumab $10.0 \mathrm{mg} / \mathrm{kg}(\mathrm{n}=4)$ or placebo

Group 5: SC etrolizumab $3.0 \mathrm{mg} / \mathrm{kg}(\mathrm{n}=4)$ or placebo

Group 6: Placebo $(n=5)$

Outcomes

Primary outcomes: adverse events, serious adverse events, dose limiting toxicity, maximum tolerated dose

Secondary outcomes: pharmacokinetic serum samples (etrolizumab concentration, maximum serum concentration, area under concentration-time curve from time 0 to infinity, area under concentration-time curve during a dosing interval, total body clearance at steady state after intravenous doses or apparent total body clearance at steady state after SC doses, elimination half-life, anti-therapeutic antibody response); pharmacodynamics evaluations (drug occupancy on target CD4+ lymphocytes; occupancy of etrolizumab;

Placebo response and remission rates in randomised trials of induction and maintenance therapy for ulcerative colitis (Review) 
Rutgeerts 2013a (Continued)

absolute number of $\mathrm{T}$ lymphocyte subsets)

Notes

Risk of bias

\begin{tabular}{|c|c|c|}
\hline Bias & Authors' judgement & Support for judgement \\
\hline $\begin{array}{l}\text { Random sequence generation (selection } \\
\text { bias) }\end{array}$ & Low risk & $\begin{array}{l}\text { Randomisation conducted by a biostatisti- } \\
\text { cian }\end{array}$ \\
\hline Allocation concealment (selection bias) & Low risk & $\begin{array}{l}\text { Centralised randomisation using an inter- } \\
\text { active voice response system }\end{array}$ \\
\hline $\begin{array}{l}\text { Blinding of participants and personnel } \\
\text { (performance bias) } \\
\text { All outcomes }\end{array}$ & Low risk & Double-blind with matched placebo \\
\hline $\begin{array}{l}\text { Blinding of outcome assessment (detection } \\
\text { bias) } \\
\text { All outcomes }\end{array}$ & Unclear risk & Not described \\
\hline $\begin{array}{l}\text { Incomplete outcome data (attrition bias) } \\
\text { All outcomes }\end{array}$ & Low risk & Withdrawals were similar across groups \\
\hline Selective reporting (reporting bias) & Low risk & All expected outcomes were reported \\
\hline Other bias & Low risk & No other apparent sources of bias \\
\hline
\end{tabular}

\section{Rutgeerts 2013b}

Methods

Participants

Interventions
Randomised, placebo-controlled, double-blind within-cohort study $(\mathrm{N}=48)$; multiple dose stage $(\mathrm{N}=23)$

Adult patients (18-70 years) with a diagnosis of UC for > 12 weeks and a MCS of $>5$ points at screening

During the multiple dose stage 5 cohorts of patients received etrolizumab or placebo: Group 7: SC etrolizumab $0.5 \mathrm{mg} / \mathrm{kg}(\mathrm{n}=4)$

Group 8: SC etrolizumab $1.5 \mathrm{mg} / \mathrm{kg}(\mathrm{n}=5)$

Group 9: SC etrolizumab $3.0 \mathrm{mg} / \mathrm{kg}(\mathrm{n}=4)$

Group 10: IV etrolizumab $4.0 \mathrm{mg} / \mathrm{kg}(\mathrm{n}=5)$

placebo: placebo $(n=5)$
Primary outcomes: adverse events, serious adverse events, dose limiting toxicity, maximum tolerated dose

Secondary outcomes: clinical response/remission at day 29, 43 and 71 (MD); pharmacokinetic serum samples (etrolizumab concentration, maximum serum concentration, 
area under concentration-time curve from time 0 to infinity, area under concentrationtime curve during a dosing interval, total body clearance at steady state after intravenous doses or apparent total body clearance at steady state after SC doses, elimination half-life, anti-therapeutic antibody response); pharmacodynamics evaluations (drug occupancy on target CD4+ lymphocytes; occupancy of etrolizumab; absolute number of T lymphocyte subsets)

Notes

Risk of bias

Bias Authors' judgement

Random sequence generation (selection Low risk bias)

Allocation concealment (selection bias) Low risk

Blinding of participants and personnel Low risk (performance bias)

All outcomes

\begin{tabular}{|c|c|c|}
\hline $\begin{array}{l}\text { Blinding of outcome assessment (detection } \\
\text { bias) } \\
\text { All outcomes }\end{array}$ & Unclear risk & Not described \\
\hline $\begin{array}{l}\text { Incomplete outcome data (attrition bias) } \\
\text { All outcomes }\end{array}$ & Low risk & $\begin{array}{l}\text { Drop-outs were balanced across groups } \\
\text { with similar reasons for withdrawal }\end{array}$ \\
\hline Selective reporting (reporting bias) & Unclear risk & All expected outcomes were reported \\
\hline Other bias & Unclear risk & $\begin{array}{l}\text { The study appears to be free of other } \\
\text { sources of bias }\end{array}$ \\
\hline
\end{tabular}

Rutgeerts 2015

Methods

Multicentre, randomised, double-blind, placebo-controlled, integrated phase 2/3 dosefinding/dose-confirming study ( $\mathrm{N}=291)$ (PURSUIT-IV)

Participants

Patients had confirmed diagnoses of UC and moderate-to-severe disease activity (MCS $6-12$, including an endoscopic subscore $\geq 2$ ), and failed to tolerate or had an inadequate response to $\geq 1$ conventional therapy, or were corticosteroid-dependent (i.e. unable to taper corticosteroids without UC symptom recurrence)

Patients who had previously received anti-TNF- $\alpha$ therapy were excluded

Interventions

Group 1: golimumab $1 \mathrm{mg} / \mathrm{kg}(\mathrm{n}=62)$

Group 2: golimumab $2 \mathrm{mg} / \mathrm{kg}(\mathrm{n}=75)$ 
Group 3: golimumab $4 \mathrm{mg} / \mathrm{kg}(\mathrm{n}=77)$

Group 4: placebo $(\mathrm{n}=77)$

Outcomes

Primary outcome: clinical response at week 6

Secondary outcomes: clinical remission, mucosal healing, MCS change, PMCS change,

IBDQ change at week 6; CRP change at weeks 2 and 4; and adverse events

Notes

See Sandborn 2014a and Sandborn 2014b for PURSUIT-M and PURSUIT-SC, respectively

Following review of data from both SC and IV induction studies enrolment in the phase III portion of PURSUIT-IV was stopped because efficacy was lower than expected; there were no safety concerns

\section{Risk of bias}

\begin{tabular}{l|ll} 
Bias & Authors' judgement & Support for judgement \\
\hline $\begin{array}{l}\text { Random sequence generation (selection } \\
\text { bias) }\end{array}$ & Low risk & $\begin{array}{l}\text { Conducted by a central randomisation cen- } \\
\text { tre }\end{array}$ \\
\hline
\end{tabular}

Allocation concealment (selection bias) Low risk

Centralised randomisation using an interactive voice response system

Blinding of participants and personnel Unclear risk (performance bias)

Not described beyond 'double-blind'

All outcomes

Blinding of outcome assessment (detection Unclear risk bias)

All outcomes

Mucosal healing was defined by a Mayo endoscopy subscore of 0 or 1 as assessed by a local endoscopist

Methods used to blind other outcome assessors were not described

Incomplete outcome data (attrition bias) Low risk All outcomes

Selective reporting (reporting bias) Low risk

Other bias
Drop-outs were balanced across groups ( 5 , 3,3 and 2 patients from the placebo, $1 \mathrm{mg} /$ $\mathrm{kg}, 2 \mathrm{mg} / \mathrm{kg}$ and $4 \mathrm{mg} / \mathrm{kg}$ groups discontinued before week 6 , respectively)

All expected outcomes were reported

The study appears to be free of other sources of bias 
Sandborn 1994

\begin{tabular}{|c|c|c|}
\hline Methods & \multicolumn{2}{|c|}{$\begin{array}{l}\text { Randomised, double-blind, placebo controlled trial comparing cyclosporine to placebo } \\
\text { for the treatment of mild-to-moderate, active, left-sided UC }(\mathrm{N}=40)\end{array}$} \\
\hline Participants & \multicolumn{2}{|c|}{$\begin{array}{l}\text { Adult patients with active (diagnosed according to symptomatic, radiographic and en- } \\
\text { doscopic criteria) left-sided disease receiving no concomitant therapy, oral steroids, oral } \\
\text { salicylates or oral steroids combined with salicylates }\end{array}$} \\
\hline Interventions & \multicolumn{2}{|c|}{$\begin{array}{l}\text { Group 1: once daily enema with cyclosporine } 350 \mathrm{mg}(\mathrm{n}=20) \\
\text { Gruop 2: placebo enema }(\mathrm{n}=20)\end{array}$} \\
\hline Outcomes & \multicolumn{2}{|c|}{$\begin{array}{l}\text { Patients were evaluated } 4 \text { weeks after treatment } \\
\text { Outcomes: clinical improvement, clinical remission, adverse events, histological disease } \\
\text { activity }\end{array}$} \\
\hline \multicolumn{3}{|l|}{ Notes } \\
\hline \multicolumn{3}{|l|}{ Risk of bias } \\
\hline Bias & Authors' judgement & Support for judgement \\
\hline $\begin{array}{l}\text { Random sequence generation (selection } \\
\text { bias) }\end{array}$ & Low risk & $\begin{array}{l}\text { Randomisation was stratified according to } \\
\text { concomitant treatment (no treatment, ora } \\
\text { steroids, oral salicylates or oral steroids } \\
\text { and oral salicylates); the randomisation se- } \\
\text { quence was developed by the Section of } \\
\text { Biostatistics }\end{array}$ \\
\hline Allocation concealment (selection bias) & Unclear risk & Not described \\
\hline $\begin{array}{l}\text { Blinding of participants and personnel } \\
\text { (performance bias) } \\
\text { All outcomes }\end{array}$ & Low risk & $\begin{array}{l}\text { All patients were instructed to add } 3.5 \mathrm{mI} \\
\text { of blinded-study medication to the enema }\end{array}$ \\
\hline $\begin{array}{l}\text { Blinding of outcome assessment (detection } \\
\text { bias) } \\
\text { All outcomes }\end{array}$ & Unclear risk & $\begin{array}{l}\text { Histological assessments were blinded } \\
\text { Methods used to blind other outcome as- } \\
\text { sessors were not described }\end{array}$ \\
\hline $\begin{array}{l}\text { Incomplete outcome data (attrition bias) } \\
\text { All outcomes }\end{array}$ & Low risk & All patients completed the study \\
\hline Selective reporting (reporting bias) & Low risk & All expected outcomes were reported \\
\hline Other bias & Low risk & $\begin{array}{l}\text { The study appears to be free of other } \\
\text { sources of bias }\end{array}$ \\
\hline
\end{tabular}

Placebo response and remission rates in randomised trials of induction and maintenance therapy for ulcerative colitis (Review) 
Sandborn 2003

\begin{tabular}{ll} 
Methods & $\begin{array}{l}\text { Randomised, double-blind, placebo-co } \\
\text { min (keratinocyte growth factor-2) to }\end{array}$ \\
\hline Participants & $\begin{array}{l}\text { Adult patients } 18 \text { years or older with mild } \\
\text { treatment with oral 5-ASA, corticoster }\end{array}$ \\
\hline Interventions & Group 1: placebo $(\mathrm{n}=28)$ \\
& Group 2: repifermin $1 \mathrm{lg} / \mathrm{kg}(\mathrm{n}=11)$ \\
& $\begin{array}{l}\text { Group 3: repifermin } 5 \mathrm{lg} / \mathrm{kg}(\mathrm{n}=11) \\
\text { Group 4: repifermin } 1 \mathrm{lg} / \mathrm{kg}(\mathrm{n}=12)\end{array}$ \\
& $\begin{array}{l}\text { Group 5: repifermin } 25 \mathrm{lg} / \mathrm{kg}(\mathrm{n}=12) \\
\text { Group 6: repifermin } 50 \mathrm{lg} / \mathrm{kg}(\mathrm{n}=14)\end{array}$
\end{tabular}

Outcomes

Primary outcomes (safety): adverse events at each visit; laboratory abnormalities; and the frequency of anti-repifermin antibodies at baseline and week 6 (and at month 6 in patients positive for antirepifermin antibody at week 6)

Primary outcome (efficacy): clinical remission

Secondary outcomes (efficacy): (i) clinical response (improvement in MCS > 3 points); (ii) clinical response (improvement in MCS $>2$ points)

Notes

Risk of bias

\begin{tabular}{|c|c|c|}
\hline Bias & Authors' judgement & Support for judgement \\
\hline
\end{tabular}

Random sequence generation (selection Low risk bias)

The randomisation schedule was generated by a statistician at Human Genome Sciences Inc. (Rockville, MD, USA)

Allocation concealment (selection bias) Low risk

Sealed randomisation envelopes were provided by the study statistician and maintained in the pharmacy or a secure drug storage facility at each site; treatment allocation was available to the study pharmacist or nurse responsible for preparing the drug, but not to other study personnel

Blinding of participants and personnel Low risk (performance bias)

Repifermin and placebo had a similar clear All outcomes

and colourless appearance

Blinding of outcome assessment (detection Unclear risk bias)

All outcomes

Incomplete outcome data (attrition bias) Low risk All outcomes

Drop-outs were balanced across treatment groups with similar reasons for withdrawal

Placebo response and remission rates in randomised trials of induction and maintenance therapy for ulcerative colitis (Review) 
Sandborn 2003 (Continued)

\begin{tabular}{|c|c|c|}
\hline Selective reporting (reporting bias) & Low risk & All expected outcomes were reported \\
\hline Other bias & Low risk & $\begin{array}{l}\text { The study appears to be free of other } \\
\text { sources of bias }\end{array}$ \\
\hline
\end{tabular}

Sandborn 2012a

Methods

ULTRA2 was a randomised, double-blind, placebo-controlled trial comparing adalimumab to placebo $(\mathrm{N}=494)$

Participants

Non-hospitalized, adult patients with moderate to severely active UC who received concomitant therapy with oral corticosteroids or immunosuppressants

Patients were stratified based on prior exposure to TNF- $\alpha$ antagonists

Interventions

Group 1: SC adalimumab $160 \mathrm{mg}$ at week $0,80 \mathrm{mg}$ at week 2, and then $40 \mathrm{mg}$ every other week $(\mathrm{n}=248)$

Group 2: placebo $(n=246)$

Outcomes

Primary outcomes: remission (MCS $<2$ with no subscore $>1$ ) at weeks 8 and 52

Secondary outcomes: clinical response, mucosal healing, adverse events

Notes

Risk of bias

\begin{tabular}{|c|c|c|}
\hline Bias & Authors' judgement & Support for judgement \\
\hline $\begin{array}{l}\text { Random sequence generation (selection } \\
\text { bias) }\end{array}$ & Low risk & $\begin{array}{l}\text { Centralised, } \\
\text { computer-generated randomisation (strat- } \\
\text { ified by prior anti-TNF- } \alpha \text { exposure) }\end{array}$ \\
\hline Allocation concealment (selection bias) & Unclear risk & $\begin{array}{l}\text { Centralised, } \\
\text { randomisation }\end{array}$ \\
\hline $\begin{array}{l}\text { Blinding of participants and personnel } \\
\text { (performance bias) } \\
\text { All outcomes }\end{array}$ & Low risk & Matched placebo \\
\hline $\begin{array}{l}\text { Blinding of outcome assessment (detection } \\
\text { bias) } \\
\text { All outcomes }\end{array}$ & Unclear risk & Not described \\
\hline $\begin{array}{l}\text { Incomplete outcome data (attrition bias) } \\
\text { All outcomes }\end{array}$ & Unclear risk & $\begin{array}{l}\text { Drop-outs balanced across groups with } \\
\text { similar reasons for withdrawal }\end{array}$ \\
\hline Selective reporting (reporting bias) & Unclear risk & All expected outcomes were reported \\
\hline
\end{tabular}

Placebo response and remission rates in randomised trials of induction and maintenance therapy for ulcerative colitis (Review) 


\begin{tabular}{|l|l|l}
\hline Other bias & Unclear risk & The study appears to be free of other
\end{tabular}

\section{Sandborn 2012b}

\begin{tabular}{|c|c|}
\hline Methods & $\begin{array}{l}\text { Prospective, multicenter, double-blind, double-dummy, randomised, placebo-controlled } \\
\text { trial }(\mathrm{N}=509)\end{array}$ \\
\hline Participants & $\begin{array}{l}\text { Adult patients (18-75 years) with mild-to-moderate UC (defined by UCDAI } \geq 4 \text { and } \\
\leq 10 \text { ) } \\
A \geq 2 \text {-day wash out period for oral mesalamine or other } 5 \text {-ASA product was required } \\
\text { Patients were excluded if there was a history of oral or rectal corticosteroid, immunosup- } \\
\text { pressant or biologic use within the preceding } 4 \text { weeks, } 8 \text { weeks and } 3 \text { months, respectively }\end{array}$ \\
\hline Interventions & $\begin{array}{l}\text { Participants were randomised to one of } 4 \text { groups: } \\
\text { Group 1: Budesonide-MMX } 9 \mathrm{mg}(\mathrm{n}=123) \\
\text { Group 2: Budesonide-MMX } 6 \mathrm{mg}(\mathrm{n}=121) \\
\text { Group 3: placebo }(\mathrm{n}=121) \\
\text { Group 4: Asacol } 2.4 \mathrm{~g} / \text { day (mesalamine } 800 \mathrm{mg} 3 \text { times daily) }(\mathrm{n}=124)\end{array}$ \\
\hline
\end{tabular}

\begin{tabular}{ll} 
Outcomes & $\begin{array}{l}\text { Primary outcome: combined clinical and endoscopic remission at } 8 \text { weeks } \\
\text { Secondary outcomes: clinical improvement ( } \geq 3 \text { point reduction in UCDAI), endoscopic } \\
\text { improvement, symptom resolution, histologic healing, adverse events/potential gluco- } \\
\text { corticoid adverse effects }\end{array}$ \\
\hline Notes & $\begin{array}{l}\text { A modified ITT analysis was used by the authors } \\
\text { Details on the reasons for the use of the modified ITT analysis are available in the FDA } \\
\text { Review document produced by Dr. Marjorie Dennis, available at http://www.accessdata. } \\
\text { fda.gov/drugsatfda_docs/nda/2013/203634_uceris_toc.cfm }\end{array}$ \\
\hline
\end{tabular}

\section{Risk of bias}

\begin{tabular}{l|l|l}
\hline Bias & Authors' judgement & Support for judgement \\
\hline $\begin{array}{l}\text { Random sequence generation (selection } \\
\text { bias) }\end{array}$ & Low risk & Patients were randomised in blocks \\
\hline $\begin{array}{l}\text { Allocation concealment (selection bias) } \\
\text { Llinding of participants and personnel }\end{array}$ & Low risk & Rew risk \\
$\begin{array}{l}\text { All outcomes } \\
\text { performance bias) }\end{array}$ & & using an interactive voice response system \\
\hline $\begin{array}{l}\text { Blinding of outcome assessment (detection } \\
\text { bias) } \\
\text { All outcomes }\end{array}$ & Low risk & $\begin{array}{l}\text { Physicians, patients and outcome assessors } \\
\text { were blinded to the treatment allocation }\end{array}$ \\
\hline
\end{tabular}

Placebo response and remission rates in randomised trials of induction and maintenance therapy for ulcerative colitis (Review) 


\section{Sandborn 2012b (Continued)}

\begin{tabular}{|c|c|c|}
\hline $\begin{array}{l}\text { Incomplete outcome data (attrition bias) } \\
\text { All outcomes }\end{array}$ & Low risk & $\begin{array}{l}\text { All patients were accounted for in the final } \\
\text { analysis which was a modified ITT analysis } \\
349 / 489(71.4 \%) \text { patients in the modified } \\
\text { ITT group completed the study } \\
\text { Proportions of patients who did not com- } \\
\text { plete the study and reasons for discontinu- } \\
\text { ation were similar across treatment groups }\end{array}$ \\
\hline Selective reporting (reporting bias) & Low risk & All expected outcomes were reported \\
\hline Other bias & Low risk & $\begin{array}{l}\text { The study appears to be free of other } \\
\text { sources of bias }\end{array}$ \\
\hline
\end{tabular}

Sandborn 2012c

Methods

Participants

Interventions
Multicenter, randomised, double-blind, placebo-controlled trial $(\mathrm{N}=194)$

Adult patients $>18$ years with a confirmed diagnosis of UC for $>3$ months Patients were required to have a MCS between 6-12

Use of oral mesalamine or oral prednisone at a stable dose of $30 \mathrm{mg}$ or less per day was permitted

Group 1: tofacitinib (CP-690, 550) $0.5 \mathrm{mg}(\mathrm{n}=31)$

Group 2: tofacitinib (CP-690, 550) $3.0 \mathrm{mg}(\mathrm{n}=33)$

Group 3: tofacitinib (CP-690, 550) $10.0 \mathrm{mg}(\mathrm{n}=49)$

Group 4: tofacitinib (CP-690, 550) $15.0 \mathrm{mg}(\mathrm{n}=48)$

Group 5: placebo $(\mathrm{n}=48)$

Treatment administered twice daily for 8 weeks, and followed until week 12

Primary outcome: clinical response at 8 weeks

Secondary outcomes: clinical remission at 8 weeks; endoscopic response at 8 weeks; endoscopic remission at 8 weeks; change from baseline in the PMCS at 2, 4, and 8 weeks; change from baseline in MCS at 8 weeks; change from baseline in the CRP concentration at 4 and 8 weeks; change from baseline in fecal calprotectin concentration at 2, 4, and 8 weeks; changes from baseline in low-density lipoprotein and high-density lipoprotein cholesterol concentrations and serum creatinine concentrations at 8 and 12 weeks

Notes

Risk of bias

Bias

Authors' judgement

Support for judgement

Random sequence generation (selection Low risk bias)
Randomisation was performed centrally, according to a computer-generated randomisation schedule, with the use of permuted blocks 
Sandborn 2012c (Continued)

\begin{tabular}{l|l|l}
\hline Allocation concealment (selection bias) & Low risk & $\begin{array}{l}\text { Randomisation was performed centrally, } \\
\text { according to a computer-generated ran- } \\
\text { domisation schedule, with the use of per- } \\
\text { muted blocks }\end{array}$ \\
\hline $\begin{array}{l}\text { Blinding of participants and personnel } \\
\text { (performance bias) } \\
\text { All outcomes }\end{array}$ & Unclear risk & Not described \\
\hline $\begin{array}{l}\text { Blinding of outcome assessment (detection } \\
\text { bias) } \\
\text { All outcomes }\end{array}$ & Unclear risk & Not described \\
\hline $\begin{array}{l}\text { Incomplete outcome data (attrition bias) } \\
\text { All outcomes }\end{array}$ & Low risk & Drop-outs balanced across groups with \\
\hline $\begin{array}{l}\text { Selective reporting (reporting bias) } \\
\text { Similar reasons for withdrawal }\end{array}$
\end{tabular}

Sandborn 2012d

\begin{tabular}{|c|c|}
\hline Methods & Randomised, double-blind, placebo-controlled study $(\mathrm{N}=490)$ \\
\hline Participants & $\begin{array}{l}\text { Adult patients > } 18 \text { years with a confirmed diagnosis of UC for at least } 3 \text { months } \\
\text { Patients had a MCS of 6-12, and a current/previous inadequate response to (or did } \\
\text { not tolerate): oral 5-aminosalicylates for } 6 \text { weeks, prednisone } 40 \mathrm{mg} / \text { day for } 2 \text { weeks or } \\
\text { intravenous hydrocortisone } 400 \mathrm{mg} / \text { day for } 1 \text { week } \\
\text { Concurrent therapies, including stable doses of oral } 5 \text {-ASA, prednisolone ( } 30 \mathrm{mg} / \text { day) } \\
\text {, budesonide ( } 9 \mathrm{mg} / \text { day; Crohn's disease), AZA, 6-MP, methotrexate (Crohn's disease), } \\
\text { and antibiotics (Cron's disease) were permitted }\end{array}$ \\
\hline Interventions & $\begin{array}{l}\text { Group 1: abatacept } 30 \mathrm{mg} / \mathrm{kg}(\mathrm{n}=141) \\
\text { Group 2: abatacept } 10 \mathrm{mg} / \mathrm{kg}(\mathrm{n}=139) \\
\text { Group 3: abatacept } 3 \mathrm{mg} / \mathrm{kg}(\mathrm{n}=70) \\
\text { Group 4: placebo }(\mathrm{n}=140) \\
\text { Patients were dosed at weeks } 0,2,4 \text {, and } 8\end{array}$ \\
\hline Outcomes & $\begin{array}{l}\text { Primary outcome: response at week } 12 \\
\text { Secondary outcomes: remission and mucosal healing at week } 12\end{array}$ \\
\hline \multicolumn{2}{|l|}{ Notes } \\
\hline Risk of & \\
\hline
\end{tabular}

Bias

Authors' judgement

Support for judgement

Placebo response and remission rates in randomised trials of induction and maintenance therapy for ulcerative colitis (Review) 
Sandborn 2012d (Continued)

\begin{tabular}{|c|c|c|}
\hline $\begin{array}{l}\text { Random sequence generation (selection } \\
\text { bias) }\end{array}$ & Unclear risk & Not described \\
\hline Allocation concealment (selection bias) & Low risk & $\begin{array}{l}\text { Randomisation was performed centrally } \\
\text { using dynamic treatment allocation }\end{array}$ \\
\hline $\begin{array}{l}\text { Blinding of participants and personnel } \\
\text { (performance bias) } \\
\text { All outcomes }\end{array}$ & Unclear risk & Not described \\
\hline $\begin{array}{l}\text { Blinding of outcome assessment (detection } \\
\text { bias) } \\
\text { All outcomes }\end{array}$ & Unclear risk & $\begin{array}{l}\text { Colon biopsies were analyzed by a central } \\
\text { pathologist in a blinded fashion } \\
\text { Methods for blinding other outcome asses- } \\
\text { sors were not described }\end{array}$ \\
\hline $\begin{array}{l}\text { Incomplete outcome data (attrition bias) } \\
\text { All outcomes }\end{array}$ & Low risk & $\begin{array}{l}\text { Patients who discontinued were considered } \\
\text { not to have a response/remission } \\
\text { Discontinuation was balanced across } \\
\text { groups with similar reasons for withdrawal } \\
\text { ( } 4 / 141 \mathrm{in} \text { the } 30 \mathrm{mg} / \mathrm{kg} \text { group; } 6 / 139 \mathrm{in} \\
\text { the } 10 \mathrm{mg} / \mathrm{kg} \text { group ; } 2 / 70 \text { in the } 3 \mathrm{mg} / \mathrm{kg} \\
\text { group; } 5 / 140 \text { in the placebo group) }\end{array}$ \\
\hline Selective reporting (reporting bias) & Unclear risk & All expected outcomes were reported \\
\hline Other bias & Unclear risk & $\begin{array}{l}\text { The study appears to be free of other } \\
\text { sources of bias }\end{array}$ \\
\hline
\end{tabular}

Sandborn 2013a (BUCF3001)

Methods

Participants

Interventions

Outcomes

Notes
Phase III, multi-centre, randomised, double-blind, placebo-controlled trial $(\mathrm{N}=265)$

Adult subjects with mild-to-moderately active (defined as baseline MMDAI between 510 and a score $>2$ for endoscopic and rectal bleeding subscore) ulcerative proctitis or ulcerative proctosigmoiditis

Patients were randomised 1:1 to receive rectally administered budesonide foam $2 \mathrm{mg} / 25$ $\mathrm{mL}$ twice daily for 2 weeks followed by $2 \mathrm{mg} / 25 \mathrm{~mL}$ once daily for 4 weeks, or placebo

Primary outcome: proportion of patients achieving remission at week 6

Secondary outcomes: safety assessments

Reported in abstract form only

Identical in design to BUCF3002

\section{Risk of bias}

Placebo response and remission rates in randomised trials of induction and maintenance therapy for ulcerative colitis (Review) 
Sandborn 2013a (BUCF3001) (Continued)

\begin{tabular}{l|l|l}
\hline Bias & Authors judgement & Support for judgement \\
\hline $\begin{array}{l}\text { Random sequence generation (selection } \\
\text { bias) }\end{array}$ & Unclear risk & Not described \\
\hline $\begin{array}{l}\text { Allocation concealment (selection bias) } \\
\text { Blinding of participants and personnel } \\
\text { (performance bias) }\end{array}$ & Unclear risk & Not described \\
\hline $\begin{array}{l}\text { All outcomes } \\
\text { Blinding of outcome assessment (detection } \\
\text { bias) } \\
\text { All outcomes }\end{array}$ & Unclear risk & Not described \\
\hline $\begin{array}{l}\text { Incomplete outcome data (attrition bias) } \\
\text { All outcomes }\end{array}$ & Unclear risk & Not described \\
\hline \begin{tabular}{l} 
Selective reporting (reporting bias) \\
\hline $\begin{array}{l}\text { Other bias }\end{array}$
\end{tabular} & Unclear risk & $\begin{array}{l}\text { Proportions rather than final counts re- } \\
\text { ported in abstract }\end{array}$ \\
\hline
\end{tabular}

Sandborn 2013b (BUCF3002)

\begin{tabular}{ll}
\hline Methods & Phase III, multi-centre, randomised, double-blind, placebo-controlled trial (N = 281) \\
\hline Participants & $\begin{array}{l}\text { Adult subjects with mild-to-moderately active (defined as baseline MMDAI between 5- } \\
10 \text { and a score }>2 \text { for endoscopic and rectal bleeding subscore ulcerative proctitis or } \\
\text { ulcerative proctosigmoiditis }\end{array}$ \\
\hline Interventions & $\begin{array}{l}\text { Patients were randomised } 1: 1 \text { to receive budesonide foam } 2 \mathrm{mg} / 25 \mathrm{~mL} \text { twice daily for } 2 \\
\text { weeks followed by } 2 \mathrm{mg} / 25 \mathrm{~mL} \text { once daily for } 4 \text { weeks, or placebo }\end{array}$ \\
\hline Outcomes & $\begin{array}{l}\text { Primary outcome: proportion of patients achieving remission at week } 6 \\
\text { Secondary outcomes: safety assessments }\end{array}$ \\
\hline Notes & $\begin{array}{l}\text { Reported in abstract form only } \\
\text { Identical in design to BUCF3001 }\end{array}$ \\
\hline $\begin{array}{l}\text { Risk of bias } \\
\text { Bias }\end{array}$ & Authors' judgement \\
\hline $\begin{array}{l}\text { Random sequence generation } \\
\text { (selection }\end{array}$ & Unclear risk \\
\hline
\end{tabular}

Placebo response and remission rates in randomised trials of induction and maintenance therapy for ulcerative colitis (Review) 
Sandborn 2013b (BUCF3002) (Continued)

\begin{tabular}{l|ll}
\hline Allocation concealment (selection bias) & Unclear risk & Not described \\
\hline $\begin{array}{l}\text { Blinding of participants and personnel } \\
\text { (performance bias) } \\
\text { All outcomes }\end{array}$ & Unclear risk & Not described \\
\hline $\begin{array}{l}\text { Blinding of outcome assessment (detection } \\
\text { bias) } \\
\text { All outcomes }\end{array}$ & Unclear risk & Not described \\
\hline $\begin{array}{l}\text { Incomplete outcome data (attrition bias) } \\
\text { All outcomes }\end{array}$ & Unclear risk & Proportions rather than final counts re- \\
\hline Selective reporting (reporting bias) & Low risk & ported in abstract \\
\hline \begin{tabular}{l} 
Other bias \\
\hline
\end{tabular} & Unclear risk & All expected outcomes were reported \\
\hline
\end{tabular}

\section{Sandborn 2014a}

\begin{tabular}{ll} 
Methods & $\begin{array}{l}\text { Phase III, multicenter, placebo-controlled, double-blind, randomised-withdrawal study } \\
(\mathrm{N}=464)\end{array}$ \\
\hline Participants & $\begin{array}{l}\text { Participants in Program of Ulcerative Colitis Research Studies Utilizing an Invetigational } \\
\text { Treatment (PURSUIT)- M had completed } 1 \text { of } 2 \text { golimumab induction studies } \\
\text { Patients had an established diagnosis of UC with moderate-to-severe disease activity, } \\
\text { defined as a Mayo score of 6-12, with an endoscopic subscore of } 2 \text { or more }\end{array}$ \\
\hline Interventions & $\begin{array}{l}\text { Patients received the following every } 4 \text { weeks through week 52: } \\
\text { Group 1: placebo (n }=156)\end{array}$ \\
Group 2: golimumab 50 mg (n $=154)$ \\
Group 3: golimumab 100 mg (n = 154)
\end{tabular}

Notes

See Rutgeerts 2015 and Sandborn 2014b for PURSUIT IV and PURSUIT-SC, respectively

\section{Risk of bias}

Bias 
Sandborn 2014a (Continued)

\begin{tabular}{|c|c|c|}
\hline $\begin{array}{l}\text { Random sequence generation (selection } \\
\text { bias) }\end{array}$ & Low risk & Computer-generated \\
\hline Allocation concealment (selection bias) & Low risk & $\begin{array}{l}\text { Allocation to treatment was performed us- } \\
\text { ing a central randomisation centre }\end{array}$ \\
\hline $\begin{array}{l}\text { Blinding of participants and personnel } \\
\text { (performance bias) } \\
\text { All outcomes }\end{array}$ & Unclear risk & double-blind; not adequately described \\
\hline $\begin{array}{l}\text { Blinding of outcome assessment (detection } \\
\text { bias) } \\
\text { All outcomes }\end{array}$ & Unclear risk & Not adequately described \\
\hline $\begin{array}{l}\text { Incomplete outcome data (attrition bias) } \\
\text { All outcomes }\end{array}$ & Low risk & $\begin{array}{l}\text { Patients with missing data for a dichoto- } \\
\text { mous end point were considered failures } \\
\text { For continuous outcomes the last observa- } \\
\text { tion in PURSUIT-M was carried forward } \\
\text { when data was missing }\end{array}$ \\
\hline Selective reporting (reporting bias) & Low risk & All expected outcomes were reported \\
\hline Other bias & Low risk & $\begin{array}{l}\text { The study appears to be free of other } \\
\text { sources of bias }\end{array}$ \\
\hline
\end{tabular}

\section{Sandborn 2014b}

Methods

Participants

Interventions
A phase II dose-finding study and a phase III dose-confirming study (multi-centre) (PURSUIT-SC)

Patients had moderate-to-severe UC and had an inadequate response or failed to tolerate 1 or more of the following conventional therapies: oral 5-ASA, oral corticosteroids, AZA, and 6-MP

Phase II $(\mathrm{N}=169)$

Group 1: SC golimumab 100/50 mg $(\mathrm{n}=41)$

Group 2: SC golimumab 200/100 mg $(\mathrm{n}=42)$

Group 3: SC golimumab 400/200 mg $(\mathrm{n}=43)$

Group 4: placebo $(\mathrm{n}=42)$

Phase III $(\mathrm{N}=774)$

Group 1: SC golimumab 200/100 mg $(\mathrm{n}=258)$

Group 2: SC golimumab 400/200 mg $(\mathrm{n}=258)$

Group 3: placebo $(\mathrm{n}=258)$

Patients received treatment at weeks 0 and 2

Outcomes

Primary outcome: clinical response at week 6

Secondary outcomes: clinical remission at week 6, mucosal healing, and IBDQ score change 


\section{Risk of bias}

\begin{tabular}{|c|c|c|}
\hline Bias & Authors' judgement & Support for judgement \\
\hline $\begin{array}{l}\text { Random sequence generation (selection } \\
\text { bias) }\end{array}$ & Unclear risk & Computer-generated \\
\hline Allocation concealment (selection bias) & Unclear risk & $\begin{array}{l}\text { Allocation to treatment was performed us- } \\
\text { ing a central randomisation centre }\end{array}$ \\
\hline $\begin{array}{l}\text { Blinding of participants and personnel } \\
\text { (performance bias) } \\
\text { All outcomes }\end{array}$ & Unclear risk & Double-blind; not described in detail \\
\hline $\begin{array}{l}\text { Blinding of outcome assessment (detection } \\
\text { bias) } \\
\text { All outcomes }\end{array}$ & Unclear risk & Not described in detail \\
\hline $\begin{array}{l}\text { Incomplete outcome data (attrition bias) } \\
\text { All outcomes }\end{array}$ & Unclear risk & $\begin{array}{l}\text { Drop-outs were balanced across groups } \\
\text { with similar reasons for withdrawal }\end{array}$ \\
\hline Selective reporting (reporting bias) & Unclear risk & All expected outcomes were reported \\
\hline Other bias & Unclear risk & $\begin{array}{l}\text { The study appears to be free of other } \\
\text { sources of bias }\end{array}$ \\
\hline
\end{tabular}

\section{Sandborn 2015}

Methods

Participants

Interventions
Phase IIa randomised, double-blind, placebo-controlled,8-week study $(\mathrm{N}=252)$

Patients $\geq 18$ years of age with moderately to severely active UC (confirmed by endoscopic evidence; MCS $\geq 6$ and a Mayo endoscopic subscore $\geq 2$ within the 2 weeks prior

to study drug administration)

Group 1: IV eldelumab $15 \mathrm{mg} / \mathrm{kg}(\mathrm{n}=84)$

Group 2: IV eldelumab $25 \mathrm{mg} / \mathrm{kg}(\mathrm{n}=85)$

Group 3: placebo $(\mathrm{n}=83)$

Patients treated on days 1 and 8 and every other week thereafter

Outcomes

Primary outcome: clinical remission $(\mathrm{MCS} \leq 2$; no individual subscale score $>1$ ) at week 11

Secondary outcomes: MCS, clinical response and mucosal healing at week 11

Notes

Placebo response and remission rates in randomised trials of induction and maintenance therapy for ulcerative colitis (Review) 
Sandborn 2015 (Continued)

\begin{tabular}{|c|c|c|}
\hline Bias & Authors' judgement & Support for judgement \\
\hline $\begin{array}{l}\text { Random sequence generation (selection } \\
\text { bias) }\end{array}$ & Unclear risk & $\begin{array}{l}\text { Randomisation numbers were assigned in } \\
\text { the order in which patients qualified for } \\
\text { treatment }\end{array}$ \\
\hline Allocation concealment (selection bias) & Low risk & $\begin{array}{l}\text { Sponsor-owned central randomisation sys- } \\
\text { tem allocated treatment }\end{array}$ \\
\hline $\begin{array}{l}\text { Blinding of participants and personnel } \\
\text { (performance bias) } \\
\text { All outcomes }\end{array}$ & Low risk & $\begin{array}{l}\text { Treatment assignment was blinded for pa- } \\
\text { tients and study site personnel and main- } \\
\text { tained throughout the study }\end{array}$ \\
\hline $\begin{array}{l}\text { Blinding of outcome assessment (detection } \\
\text { bias) } \\
\text { All outcomes }\end{array}$ & Unclear risk & $\begin{array}{l}\text { Endoscopy subscores were determined by } \\
\text { the local investigator who was } \\
\text { blinded to treatment assignment; central } \\
\text { reading was not employed }\end{array}$ \\
\hline $\begin{array}{l}\text { Incomplete outcome data (attrition bias) } \\
\text { All outcomes }\end{array}$ & Unclear risk & $\begin{array}{l}\text { Drop-outs were balanced across groups } \\
\text { with similar reasons for withdrawal }\end{array}$ \\
\hline Selective reporting (reporting bias) & Unclear risk & All expected outcomes were reported \\
\hline Other bias & Unclear risk & $\begin{array}{l}\text { The study appears to be free of other } \\
\text { sources of bias }\end{array}$ \\
\hline
\end{tabular}

Sands 2012

Methods

Participants

Interventions
Multicenter, randomised, double-blind, placebo-controlled phase II trial ( $\mathrm{N}=149)$

Patients 18-75 years with moderate to severe UC (extending beyond the rectum) despite treatment for at least 14 days with oral prednisone $(40-50 \mathrm{mg} /$ day $)$

Group 1: basiliximab $20 \mathrm{mg}(\mathrm{n}=46)$

Group 2: basiliximab $40 \mathrm{mg}(\mathrm{n}=52)$

Group 3: placebo $(\mathrm{n}=51)$

All subjects received $30 \mathrm{mg} /$ day prednisone through week 2; the dose was reduced by 5 $\mathrm{mg}$ each week to $20 \mathrm{mg} /$ day which was maintained until week 8

Outcomes

Primary outcome: clinical remission at week 8

Secondary outcomes: clinical remission at week 4 , clinical response at weeks 4 and 8 , mucosal healing at weeks 4 and 8 , clinical relapse after week 4 (for subjects in clinical remission at week 4), and concomitant corticosteroid use (median daily dose over time and cumulative dose)

Notes

Placebo response and remission rates in randomised trials of induction and maintenance therapy for ulcerative colitis (Review) 
Sands 2012 (Continued)

Risk of bias

\begin{tabular}{|c|c|c|}
\hline Bias & Authors' judgement & Support for judgement \\
\hline $\begin{array}{l}\text { Random sequence generation (selection } \\
\text { bias) }\end{array}$ & Low risk & Computer-generated randomisation \\
\hline Allocation concealment (selection bias) & Low risk & $\begin{array}{l}\text { Centralised randomisation using an inter- } \\
\text { active web response system }\end{array}$ \\
\hline $\begin{array}{l}\text { Blinding of participants and personnel } \\
\text { (performance bias) } \\
\text { All outcomes }\end{array}$ & Low risk & $\begin{array}{l}\text { All sponsor and study site personnel, in- } \\
\text { cluding the endoscopist and pathologist, } \\
\text { were blinded to subject treatment assign- } \\
\text { ment } \\
\text { Identically packaged placebo }\end{array}$ \\
\hline $\begin{array}{l}\text { Blinding of outcome assessment (detection } \\
\text { bias) } \\
\text { All outcomes }\end{array}$ & Low risk & $\begin{array}{l}\text { All sponsor and study site personnel, in- } \\
\text { cluding the endoscopist and pathologist, } \\
\text { were blinded to subject treatment assign- } \\
\text { ment }\end{array}$ \\
\hline $\begin{array}{l}\text { Incomplete outcome data (attrition bias) } \\
\text { All outcomes }\end{array}$ & Low risk & $\begin{array}{l}\text { Drop-outs were balanced across groups } \\
\text { with similar reasons for withdrawal }\end{array}$ \\
\hline Selective reporting (reporting bias) & Unclear risk & All expected outcomes reported \\
\hline Other bias & Unclear risk & $\begin{array}{l}\text { The study appears to be free of other } \\
\text { sources of bias }\end{array}$ \\
\hline
\end{tabular}

Scherl 2009

Methods

Participants

Phase III, randomised, prospective, double-blind, placebo-controlled study ( $\mathrm{N}=249)$

Interventions

Group 1: balsalazide $1.1 \mathrm{~g}$ (administered as three tablets twice daily for 8 weeks)

Group 2: matched placebo

Patients were instructed to return unused study drug and used or partially used packaging at weeks $1,2,4$, and 8 to determine compliance with therapy

Outcomes

Primary outcome: proportion of patients achieving clinical improvement ( $\geq 3$ point improvement in MMDAI) and improvement in rectal bleeding ( $\geq 1$ point improvement) at 8 weeks

Secondary outcomes: proportion of patients in clinical remission, proportion of patients

Placebo response and remission rates in randomised trials of induction and maintenance therapy for ulcerative colitis (Review) 
Scherl 2009 (Continued)

with mucosal healing, proportion of patients with complete remission and mean change

from baseline in MMDAI score

\begin{tabular}{|c|c|c|}
\hline Notes & & \\
\hline \multicolumn{3}{|l|}{ Risk of bias } \\
\hline Bias & Authors' judgement & Support for judgement \\
\hline $\begin{array}{l}\text { Random sequence generation (selection } \\
\text { bias) }\end{array}$ & Unclear risk & Not described \\
\hline Allocation concealment (selection bias) & Low risk & $\begin{array}{l}\text { Patients were randomised }(2: 1) \text {, using a } \\
\text { centralized, automated, validated interac- } \\
\text { tive voice response system }\end{array}$ \\
\hline $\begin{array}{l}\text { Blinding of participants and personnel } \\
\text { (performance bias) } \\
\text { All outcomes }\end{array}$ & Low risk & $\begin{array}{l}\text { Both the investigator and patient were } \\
\text { blinded to assigned treatment throughout } \\
\text { the study } \\
\text { All tablets were identical in appearance }\end{array}$ \\
\hline $\begin{array}{l}\text { Blinding of outcome assessment (detection } \\
\text { bias) } \\
\text { All outcomes }\end{array}$ & Unclear risk & Not described \\
\hline $\begin{array}{l}\text { Incomplete outcome data (attrition bias) } \\
\text { All outcomes }\end{array}$ & Low risk & $\begin{array}{l}\text { Drop-outs balanced across groups with } \\
\text { similar reasons for withdrawal }\end{array}$ \\
\hline Selective reporting (reporting bias) & Low risk & All expected outcomes were reported \\
\hline Other bias & Low risk & $\begin{array}{l}\text { The study appears to be free of other } \\
\text { sources of bias }\end{array}$ \\
\hline
\end{tabular}

Schreiber 2007

\begin{tabular}{ll}
\hline Methods & Multicenter, randomised, double-blind, placebo-controlled study $(\mathrm{N}=186)$ \\
\hline Participants & $\begin{array}{l}\text { Outpatients (male or female) } 18-80 \text { years of age with a clinical diagnosis of mild-to- } \\
\text { moderately active UC involving the colon proximal to } 15 \mathrm{~cm} \text { above the anal verge and } \\
\text { with a baseline UCDAI score of } 4-11\end{array}$ \\
\hline Interventions & $\begin{array}{l}\text { Group } 1: \text { tetomilast } 25 \mathrm{mg}(\mathrm{n}=62) \\
\text { Group 2: tetomilast } 50 \mathrm{mg}(\mathrm{n}=62) \\
\text { Group 3: placebo }(\mathrm{n}=62)\end{array}$ \\
\hline Outcomes & $\begin{array}{l}\text { Primary outcome: improvement at week } 8 \text { (defined as a reduction of 3 points in the total } \\
\text { UCDAI score compared to baseline) } \\
\text { Secondary outcomes: proportion of patients in remission (UCDAI score, 0-1), clini- } \\
\text { cal improvement at week 4, change from baseline in total UCDAI score and UCDAI }\end{array}$ \\
\hline
\end{tabular}

Placebo response and remission rates in randomised trials of induction and maintenance therapy for ulcerative colitis (Review) 
component scores, change from baseline in quality of life, proportion of patients with improvement in the Feagan Score, time to clinical improvement (number of days from randomisation to the first visit

with clinical improvement), and time to remission (number of days from randomisation to the first visit with remission)

Notes

Risk of bias

\begin{tabular}{|c|c|c|}
\hline Bias & Authors' judgement & Support for judgement \\
\hline $\begin{array}{l}\text { Random sequence generation (selection } \\
\text { bias) }\end{array}$ & Unclear risk & Not described \\
\hline Allocation concealment (selection bias) & Unclear risk & Not described \\
\hline $\begin{array}{l}\text { Blinding of participants and personnel } \\
\text { (performance bias) } \\
\text { All outcomes }\end{array}$ & Low risk & $\begin{array}{l}\text { With the exception of the programmer and } \\
\text { project statistician performing the interim } \\
\text { analyses, all persons involved in the con- } \\
\text { duct and management of the study were } \\
\text { blinded to the individual patient treatment } \\
\text { assignments until after the database was } \\
\text { locked } \\
\text { The blind was not broken for any patient } \\
\text { during this study } \\
\text { Matching placebo tablets }\end{array}$ \\
\hline
\end{tabular}

Blinding of outcome assessment (detection Low risk bias)

With the exception of the programmer and project statistician performing the interim analyses, all persons involved in the con-

All outcomes duct and management of the study were blinded to the individual patient treatment assignments until after the database was locked

The blind was not broken for any patient during this study

Incomplete outcome data (attrition bias) Low risk All outcomes

Selective reporting (reporting bias) Low risk

Other bias
Low risk
Drop-outs balanced across groups with similar reasons for withdrawal

All expected outcomes were reported

The study appears to be free of other sources of bias 
Schroeder 1987

\begin{tabular}{|c|c|}
\hline Methods & Placebo-controlled, double-blind, and randomised study $(\mathrm{N}=87)$ \\
\hline Participants & $\begin{array}{l}\text { Patients, age } 15-70 \text { years, with mild-to-moderate UC (defined by symptomatic, radio- } \\
\text { graphic, endoscopic criteria) } \\
\text { Patients receiving corticosteroids or SASP were required to stop such therapy at least } 1 \\
\text { week prior to start of study } \\
\text { Pre-entry evaluations included history, physical, blood count, chemistry screening, uri- } \\
\text { nalysis, stool sample (had to be negative for ova, parasites, enteric pathogens) }\end{array}$ \\
\hline Interventions & $\begin{array}{l}\text { Group 1: } 4.8 \mathrm{~g} / \text { day Asacol }(400 \mathrm{mg} \text { of } 5 \text {-ASA, coated with } \mathrm{pH} \text {-sensitive polymer Eu- } \\
\text { dragit-S which dissolves at } \mathrm{pH} 7 \text { or higher })(\mathrm{n}=38) \\
\text { Group 2: } 1.6 \mathrm{~g} / \text { day Asacol }(400 \mathrm{mg} \text { of } 5 \text {-ASA, coated with } \mathrm{pH} \text {-sensitive polymer Eu- } \\
\text { dragit-S which dissolves at } \mathrm{pH} 7 \mathrm{or} \text { higher })(\mathrm{n}=11) \\
\text { Group 3: matched placebo }(500 \mathrm{mg} \text { microcellulose with identical } \mathrm{pH} \text {-sensitive coating } \\
(\mathrm{n}=38) \\
\text { Patients received } 12 \text { tablets daily for } 6 \text { weeks }\end{array}$ \\
\hline
\end{tabular}

Outcomes

Primary outcome: clinical response, described as 'complete', 'partial', or 'no response', was determined on the basis of stool frequency, amount of rectal bleeding, and physician's global assessment (which included sigmoidoscopic appearance) on 4-point scales, compared to baseline data

Secondary outcomes: complete response' indicated resolution of all symptoms, adverse events

Notes

Early termination of treatment for any reason was deemed to constitute treatment failure

\section{Risk of bias}

\begin{tabular}{l|l|l} 
Bias & Authors' judgement & Support for judgement \\
\hline $\begin{array}{l}\text { Random sequence generation (selection } \\
\text { bias) }\end{array}$ & Low risk & $\begin{array}{l}\text { Randomisation sequence was developed by } \\
\text { the Section of Medical Research Statistics, } \\
\text { Rochester Methodist Hospital }\end{array}$ \\
\hline $\begin{array}{l}\text { Allocation concealment (selection bias) } \\
\text { Blinding of participants and personnel } \\
\text { (performance bias) } \\
\text { All outcomes }\end{array}$ & Low risk & Centralized randomisation by pharmacist \\
\hline $\begin{array}{l}\text { Blinding of outcome assessment (detection } \\
\text { bias) } \\
\text { All outcomes }\end{array}$ & Unclear risk & Double-blind: matching placebo \\
\hline $\begin{array}{l}\text { Incomplete outcome data (attrition bias) } \\
\text { All outcomes }\end{array}$ & Unclear risk & Not described \\
\hline & & $\begin{array}{l}\text { More placebo patients (n=16) did not com- } \\
\text { plete the study than 5-ASA patients (n = 5) } \\
\text { Placebo patients were more likely to drop } \\
\text { out do to flare of UC or no improvement }\end{array}$
\end{tabular}

Placebo response and remission rates in randomised trials of induction and maintenance therapy for ulcerative colitis (Review) 
Schroeder 1987 (Continued)

\begin{tabular}{|c|c|c|}
\hline Selective reporting (reporting bias) & Low risk & All expected outcomes were reported \\
\hline Other bias & Low risk & $\begin{array}{l}\text { The study appears to be free of other } \\
\text { sources of bias }\end{array}$ \\
\hline
\end{tabular}

\section{Sninsky 1991}

Methods

Participants
Multicenter, double-blind, placebo-controlled, computer-randomised study $(\mathrm{N}=158)$

Patients, age 18-75 years, with mild-to-moderately active UC as diagnosed by symptomatic, radiographic, and endoscopic criteria

Cases of both newly and previously diagnosed disease showing continued active signs, despite SASP therapy were included

Steroid therapy had to be stopped at least one month before start of study

SASP and topical rectal therapies were discontinued at least 1 week before start of study

Concomitant use of other investigational drugs was not permitted

Interventions

Group 1: $1.6 \mathrm{~g} /$ day oral mesalamine (Asacol) in $400 \mathrm{mg}$ tablets coated with $\mathrm{pH}$-sensitive polymer (Eudragit-S) $(\mathrm{n}=53)$

Group 2: $2.4 \mathrm{~g} /$ day oral mesalamine (Asacol) in $400 \mathrm{mg}$ tablets coated with $\mathrm{pH}$-sensitive polymer (Eudragit-S) $(\mathrm{n}=53)$

Group 3: placebo tablets $(\mathrm{n}=52)$

Outcomes

Primary outcome: Clinical grading was based on stool frequency, rectal bleeding, sigmoidoscopic findings, and patient's functional assessment, each on 4-point scale, which together gave the 'physician's global assessment', also on a 4-point scale. The change in this clinical grade was indicated by classifying each patient as being 'in remission', 'improved', 'maintained', or 'worsened'

Secondary outcomes: withdrawals and adverse events

Notes

\section{Risk of bias}

\section{Bias}

Random sequence generation (selection Low risk bias)

\begin{tabular}{l|l|l}
\hline Allocation concealment (selection bias) & Unclear risk & Not described \\
\hline $\begin{array}{l}\text { Blinding of participants and personnel } \\
\text { (performance bias) } \\
\text { All outcomes }\end{array}$ & Low risk & Double-blind: \\
\hline $\begin{array}{l}\text { Blinding of outcome assessment (detection } \\
\text { bias) }\end{array}$ & Unclear risk & Not described \\
All outcomes & & \\
\hline
\end{tabular}

Placebo response and remission rates in randomised trials of induction and maintenance therapy for ulcerative colitis (Review)

Copyright @ 2017 The Cochrane Collaboration. Published by John Wiley \& Sons, Ltd.

\section{Support for judgement}

Computer-generated

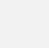




\begin{tabular}{l|ll}
\hline $\begin{array}{l}\text { Incomplete outcome data (attrition bias) } \\
\text { All outcomes }\end{array}$ & Unclear risk & $\begin{array}{l}\text { Drop-outs balanced across intervention } \\
\text { groups with similar reasons for withdrawal }\end{array}$ \\
\hline Selective reporting (reporting bias) & Unclear risk & All expected outcomes were reported \\
\hline Other bias & Unclear risk & $\begin{array}{l}\text { The study appears to be free of other } \\
\text { sources of bias }\end{array}$ \\
\hline
\end{tabular}

\section{Steinhart 1996}

\begin{tabular}{ll} 
Methods & A 6-week, randomised, double-blind trial $(\mathrm{N}=38)$ \\
\hline Participants & $\begin{array}{l}43 \text { patients were initially randomised; } 5 \text { patients were excluded due to protocol violations } \\
\text { Patients were diagnosed with ulcerative proctosigmoiditis and had endoscopic evidence } \\
\text { of inflammation occurring between } 5-60 \mathrm{~cm} \text { from the anal verge }\end{array}$
\end{tabular}

Interventions Nightly butyrate enema $(\mathrm{n}=19)$ or placebo (saline) enema $(\mathrm{n}=19)$

Maximum treatment duration was 6 weeks

Concomitant oral medications were held constant

Topical rectal therapies were discontinued

Outcomes

Primary outcome: clinical improvement (a decrease in UCDAI $>2$ or a score $<3$ at week 6)

Secondary outcomes: complete response (remission or complete response, as defined by a UCDAI score < 3), UCDAI score, endoscopic mucosal appearance, histological grade, adverse events, compliance

Notes

\section{Risk of bias}

\begin{tabular}{l|l|l}
\hline Bias & Authors' judgement & Support for judgement \\
\hline $\begin{array}{l}\text { Random sequence generation (selection } \\
\text { bias) }\end{array}$ & Unclear risk & Not described \\
\hline $\begin{array}{l}\text { Allocation concealment (selection bias) } \\
\text { Blinding of participants and personnel } \\
\text { (performance bias) } \\
\text { All outcomes }\end{array}$ & Low risk & Not described \\
\hline $\begin{array}{l}\text { Blinding of outcome assessment (detection } \\
\text { bias) } \\
\begin{array}{l}\text { All outcomes } \\
\hline\end{array}\end{array}$ & Unclear risk & $\begin{array}{l}\text { The concentration, dose and frequency of } \\
\text { the enemas were identical }\end{array}$ \\
\hline
\end{tabular}




\section{Steinhart 1996 (Continued)}

\begin{tabular}{|c|c|c|}
\hline $\begin{array}{l}\text { Incomplete outcome data (attrition bias) } \\
\text { All outcomes }\end{array}$ & Low risk & $\begin{array}{l}\text { Drop-outs were balanced across groups } \\
\text { with similar reasons for withdrawal } \\
28 / 38 \text { patients completed the } 6 \text { week study } \\
\text { ( } 14 \text { placebo, } 14 \text { experimental) }\end{array}$ \\
\hline Selective reporting (reporting bias) & Low risk & All expected outcomes were reported \\
\hline Other bias & Unclear risk & $\begin{array}{l}\text { The study appears to be free of other } \\
\text { sources of bias }\end{array}$ \\
\hline
\end{tabular}

Sutherland 1987a

\begin{tabular}{ll}
\hline Methods & Multicentre double-blind randomised placebo-controlled trial $(\mathrm{N}=153)$ \\
\hline Participants & Patients with active ulcerative colitis extending no more than $50 \mathrm{~cm}$ from the anal verge \\
\hline Interventions & $\begin{array}{l}\text { Group } 1: 5 \text {-ASA enema } 4 \mathrm{~g} / \text { day }(\mathrm{n}=76) \\
\text { Group } 2: \text { placebo }(\mathrm{n}=77) \\
\text { Patinets received treatment once daily for } 6 \text { weeks }\end{array}$ \\
\hline Outcomes & $\begin{array}{l}\text { Primary outcome: clinical response } \\
\text { Secondary outcomes: adverse events }\end{array}$ \\
\hline Notes & \\
\hline
\end{tabular}

\section{Risk of bias}

\begin{tabular}{l|l|l} 
Bias & Authors' judgement & Support for judgement \\
\hline $\begin{array}{l}\text { Random sequence generation (selection } \\
\text { bias) }\end{array}$ & Low risk & Table of random numbers \\
\hline $\begin{array}{l}\text { Allocation concealment (selection bias) } \\
\text { Blinding of participants and personnel } \\
\begin{array}{l}\text { (performance bias) } \\
\text { All outcomes }\end{array}\end{array}$ & Low risk & Centralised randomisation \\
\hline $\begin{array}{l}\text { Blinding of outcome assessment (detection } \\
\text { bias) } \\
\text { All outcomes }\end{array}$ & Unclear risk & $\begin{array}{l}\text { The medication and placebo were identical } \\
\text { in colour, consistency and packaging }\end{array}$ \\
\hline
\end{tabular}

Incomplete outcome data (attrition bias) Low risk All outcomes

Selective reporting (reporting bias)
Low risk
6 patients dropped out of the 5-ASA group for worsening disease or unsatisfactory response compared to 14 placebo patients

The published report includes all expected outcomes 
Sutherland 1987a (Continued)

\begin{tabular}{l|l|l}
\hline Other bias & Low risk & The study appears to be free of other
\end{tabular}
sources of bias

Sutherland $1987 \mathrm{~b}$

\begin{tabular}{l|l}
\hline Methods & 6-week, randomised, double-blind placebo-controlled design $(\mathrm{N}=59)$ \\
\hline Participants & $\begin{array}{l}\text { Patients were }>18 \text { years who had UC involving 5-50 cm of colon continuously from the } \\
\text { anus, confirmed by sigmoidoscopy with biopsies taken from an area of active disease } \\
\text { Patients had to have a minimum score of } 3 \text { on a 12-point DAI }\end{array}$ \\
\hline Interventions & $\begin{array}{l}\text { Group 1: } 4 \mathrm{~g} 5 \text {-ASA enema }(60 \mathrm{~mL})(\mathrm{n}=29) \\
\text { Group 2: placebo enema }(\mathrm{n}=30) \\
\text { Patients were instructed to use one enema daily at bedtime }\end{array}$ \\
\hline Outcomes & $\begin{array}{l}\text { Primary outcome: physician's global assessment of the patient at the end of the study } \\
\text { period, mean DAI }\end{array}$ \\
\hline Notes & \\
\hline
\end{tabular}

Risk of bias

\begin{tabular}{|c|c|c|}
\hline Bias & Authors' judgement & Support for judgement \\
\hline $\begin{array}{l}\text { Random sequence generation (selection } \\
\text { bias) }\end{array}$ & Low risk & Random numbers table \\
\hline Allocation concealment (selection bias) & Unclear risk & Not described \\
\hline $\begin{array}{l}\text { Blinding of participants and personnel } \\
\text { (performance bias) } \\
\text { All outcomes }\end{array}$ & Low risk & $\begin{array}{l}\text { Double-blind medication was prepackaged } \\
\text { to ensure that an equal and random assign- } \\
\text { ment within each centre occurred }\end{array}$ \\
\hline $\begin{array}{l}\text { Blinding of outcome assessment (detection } \\
\text { bias) } \\
\text { All outcomes }\end{array}$ & Unclear risk & Not described \\
\hline $\begin{array}{l}\text { Incomplete outcome data (attrition bias) } \\
\text { All outcomes }\end{array}$ & Unclear risk & $\begin{array}{l}\text { Drop-outs balanced across groups with } \\
\text { similar reasons for withdrawal } \\
\text { There were } 12 \text { dropouts (five in the active } \\
\text { and seven in the placebo group) during the } \\
\text { study because of insufficient efficacy }\end{array}$ \\
\hline Selective reporting (reporting bias) & Unclear risk & All expected outcomes were reported \\
\hline Other bias & Unclear risk & $\begin{array}{l}\text { The study appears to be free of other } \\
\text { sources of bias }\end{array}$ \\
\hline
\end{tabular}

Placebo response and remission rates in randomised trials of induction and maintenance therapy for ulcerative colitis (Review) 
Sutherland 1990

Methods

Participants

Interventions

Outcomes
Double-blind, placebo-controlled, multicenter, parallel trial $(\mathrm{N}=136)$

Adults $>18$ years with ulcerative colitis extending at least $20 \mathrm{~cm}$ proximal to the anus Patients had to have a minimum score of 4 measured by DAI (four subgroups for each of bowel frequency, presence of blood, sigmoidoscopic appearance, and physician's assessment of severity for a maximum score of 12)

Group 1: Rowasa (250 mg tablets) taken as four tablets, four times per day, $4 \mathrm{~g} /$ day (n $=47)$

Group 2: Rowasa (250 mg tablets) taken as four tablets, four times per day, $2 \mathrm{~g} / \mathrm{day}$ (n = 45)

Group 3: Identical-appearing placebo $(n=44)$

Treatment duration was 6 weeks

Primary outcome: changes in the disease activity index and PGA

The change in PGA was described as 'much or somewhat improved', 'unchanged', or 'somewhat worse or much worse'

The change in the disease activity index score was evaluated in terms of end of study score minus 'baseline'

Secondary outcome: adverse events

Notes

Risk of bias

\begin{tabular}{|c|c|c|}
\hline Bias & Authors' judgement & Support for judgement \\
\hline $\begin{array}{l}\text { Random sequence generation (selection } \\
\text { bias) }\end{array}$ & Unclear risk & Not described \\
\hline Allocation concealment (selection bias) & Unclear risk & Centralised randomisation \\
\hline $\begin{array}{l}\text { Blinding of participants and personnel } \\
\text { (performance bias) } \\
\text { All outcomes }\end{array}$ & Low risk & Double-blind: identical placebo \\
\hline $\begin{array}{l}\text { Blinding of outcome assessment (detection } \\
\text { bias) } \\
\text { All outcomes }\end{array}$ & Unclear risk & Not described \\
\hline $\begin{array}{l}\text { Incomplete outcome data (attrition bias) } \\
\text { All outcomes }\end{array}$ & Low risk & $\begin{array}{l}34 \% \text { drop-out rate, however drop-outs ap- } \\
\text { pear to be balanced across intervention } \\
\text { groups with similar reasons for withdrawal }\end{array}$ \\
\hline Selective reporting (reporting bias) & Low risk & All expected outcomes were reported \\
\hline Other bias & Low risk & $\begin{array}{l}\text { The study appears to be free of other } \\
\text { sources of bias }\end{array}$ \\
\hline
\end{tabular}

Placebo response and remission rates in randomised trials of induction and maintenance therapy for ulcerative colitis (Review) 
Suzuki 2014

Methods

Participants

Interventions

Outcomes

Notes

\section{Risk of bias}

\section{Bias}

Authors' judgement

Support for judgement

Random sequence generation (selection Unclear risk bias)

Allocation concealment (selection bias) Low risk

Blinding of participants and personnel Unclear risk (performance bias)

All outcomes

Blinding of outcome assessment (detection Unclear risk bias)

All outcomes

Incomplete outcome data (attrition bias) Low risk All outcomes 32 and 52

Secondary outcomes: rectal bleeding subscore, physician global assessment, stool frequency indicative of mild disease; IBDQ response; response per partial MCS; rates of steroid-free status and steroid-free remission at week 32 and 52 in patients taking corticosteroids at baseline

Japanese patients $>15$ years of age with biopsy-confirmed, moderately to severely active UC (defined as MCS of 6-12 points and an endoscopy subscore of $>2$ ) despite concurrent Group 1: adalimumab 80/40 $\mathrm{mg}(\mathrm{n}=87)$

Group 2: adalimumab 160/80 mg $(\mathrm{n}=90)$

Group 3: placebo $(\mathrm{n}=96)$ 
Suzuki 2015

\begin{tabular}{|c|c|c|}
\hline Methods & \multicolumn{2}{|c|}{ Randomised, double-blind, placebo-controlled trial $(\mathrm{N}=208)$} \\
\hline Participants & \multicolumn{2}{|c|}{ Patients with moderate-to-severely active UC } \\
\hline Interventions & \multicolumn{2}{|c|}{$\begin{array}{l}\text { Group 1: } 5 \mathrm{mg} / \mathrm{kg} \text { infliximab }(\mathrm{n}=104) \\
\text { Group 2: placebo }(\mathrm{n}=104) \\
\text { Patients received treatment at weeks } 0,2 \text { and } 6 \\
\text { Patients with a lower MCS at week } 8 \text { than at baseline were further treated with infliximab } \\
\text { at weeks } 14 \text { and } 22\end{array}$} \\
\hline Outcomes & \multicolumn{2}{|c|}{$\begin{array}{l}\text { Primary outcome: clinical response } \\
\text { Secondary outcomes: clinical remission, mucosal healing, serum infliximab levels, adverse } \\
\text { events }\end{array}$} \\
\hline Notes & \multicolumn{2}{|c|}{ Reported in abstract form only } \\
\hline \multicolumn{3}{|l|}{ Risk of bias } \\
\hline Bias & Authors' judgement & Support for judgement \\
\hline $\begin{array}{l}\text { Random sequence generation (selection } \\
\text { bias) }\end{array}$ & Unclear risk & Not described \\
\hline Allocation concealment (selection bias) & Unclear risk & Not described \\
\hline $\begin{array}{l}\text { Blinding of participants and personnel } \\
\text { (performance bias) } \\
\text { All outcomes }\end{array}$ & Unclear risk & Not described beyond 'double-blind' \\
\hline $\begin{array}{l}\text { Blinding of outcome assessment (detection } \\
\text { bias) } \\
\text { All outcomes }\end{array}$ & Unclear risk & Not described \\
\hline $\begin{array}{l}\text { Incomplete outcome data (attrition bias) } \\
\text { All outcomes }\end{array}$ & Unclear risk & Not described \\
\hline Selective reporting (reporting bias) & Low risk & All expected outcomes were reported \\
\hline Other bias & Unclear risk & Reported in abstract form only \\
\hline
\end{tabular}

Travis 2014

Methods

Prospective, multicenter, double-blind, double-dummy, randomised, placebo-controlled trial $(\mathrm{N}=410)$

Participants

Adult patients (18-75 years) with mild-to-moderate UC as defined by UCDAI score of $\geq 4$ and $\leq 10$ 
Travis 2014 (Continued)

\begin{tabular}{|c|c|c|}
\hline Interventions & \multicolumn{2}{|c|}{$\begin{array}{l}\text { Budesonide-MMX } 9 \mathrm{mg}(\mathrm{n}=127) \\
\text { Budesonide-MMX } 6 \mathrm{mg}(\mathrm{n}=128) \\
\text { Placebo }(\mathrm{n}=128) \\
\text { Entocort (budesonide controlled ileal release) } 9 \mathrm{mg} \text { daily }(\mathrm{n}=126) \\
\text { Placebo formulations were available for the Entocort }{ }^{\circledR} \text { capsules and the Budesonide- } \\
\text { MMX® tablets }\end{array}$} \\
\hline Outcomes & \multicolumn{2}{|c|}{$\begin{array}{l}\text { Primary outcome: combined clinical and endoscopic remission at } 8 \text { weeks (UCDAI score } \\
\leq 1 \text {, with subscores of zero for rectal bleeding and stool frequency, no mucosal friability } \\
\text { at colonoscopy and a reduction of } \geq 1 \text { point in the endoscopic index score) } \\
\text { Secondary outcomes: clinical improvement ( } \geq 3 \text { point reduction in UCDAI), endoscopic } \\
\text { improvement, symptom resolution, histologic healing and adverse events }\end{array}$} \\
\hline \multicolumn{3}{|l|}{ Notes } \\
\hline \multicolumn{3}{|l|}{ Risk of bias } \\
\hline Bias & Authors' judgement & Support for judgement \\
\hline $\begin{array}{l}\text { Random sequence generation (selection } \\
\text { bias) }\end{array}$ & Low risk & $\begin{array}{l}\text { Patients were randomised in blocks of } 4 \text { to } \\
\text { each of the treatment arms }\end{array}$ \\
\hline Allocation concealment (selection bias) & Low risk & $\begin{array}{l}\text { Centralised randomisation using an inter- } \\
\text { active voice response system }\end{array}$ \\
\hline $\begin{array}{l}\text { Blinding of participants and personnel } \\
\text { (performance bias) } \\
\text { All outcomes }\end{array}$ & Low risk & $\begin{array}{l}\text { Physicians, patients and outcome assessors } \\
\text { were blinded to the treatment allocation }\end{array}$ \\
\hline $\begin{array}{l}\text { Blinding of outcome assessment (detection } \\
\text { bias) } \\
\text { All outcomes }\end{array}$ & Low risk & $\begin{array}{l}\text { Outcome assessors were blinded to the } \\
\text { treatment allocation }\end{array}$ \\
\hline $\begin{array}{l}\text { Incomplete outcome data (attrition bias) } \\
\text { All outcomes }\end{array}$ & Low risk & $\begin{array}{l}\text { The proportions of patients who did not } \\
\text { complete the study as well as reasons for } \\
\text { study discontinuation were similar across } \\
\text { different treatment groups }\end{array}$ \\
\hline Selective reporting (reporting bias) & Low risk & All expected outcomes were reported \\
\hline Other bias & Low risk & $\begin{array}{l}\text { The study appears to be free of other } \\
\text { sources of bias }\end{array}$ \\
\hline
\end{tabular}

Placebo response and remission rates in randomised trials of induction and maintenance therapy for ulcerative colitis (Review) 
Van Assche 2006

\begin{tabular}{|c|c|c|}
\hline Methods & \multicolumn{2}{|c|}{ A randomised, double-blind, placebo-controlled, multi-centre trial $(\mathrm{N}=159)$} \\
\hline Participants & \multicolumn{2}{|c|}{$\begin{array}{l}\text { Patients ( }>12 \text { years of age) diagnosed with active UC (as defined as a Mayo score 5-10 } \\
\text { points, inclusive) for at least } 4 \text { months } \\
\text { Concurrent medication permitted: 5-ASA drugs, methylprednisolone, AZA, and 6-MP } \\
\text { Concurrent medication not permitted: methotrexate, cyclosporine, tacrolimus, antibi- } \\
\text { otics, and rectally administered corticosteroids }\end{array}$} \\
\hline Interventions & \multicolumn{2}{|c|}{$\begin{array}{l}\text { Daclizumab } 1 \mathrm{mg} / \mathrm{kg} \text { at weeks } 0 \text { and } 4(\mathrm{IV}):(\mathrm{n}=56) \text {; } \\
\text { Daclizumab } 2 \mathrm{mg} / \mathrm{kg} \text { at weeks } 0,2,4 \text {, and } 6(\mathrm{IV}):(\mathrm{n}=47) \\
\text { Placebo: }(\mathrm{n}=56)\end{array}$} \\
\hline Outcomes & \multicolumn{2}{|c|}{$\begin{array}{l}\text { Primary outcome: induction of remission at week } 8 \text { (remission defined as a MCS of } 0 \text { or } \\
\text { the endoscopic and rectal bleeding subscores and a score of } 0 \text { or } 1 \text { on the stool frequency } \\
\text { and physician's global assessment subscores) } \\
\text { Secondary outcomes: response at week } 8 \text {; clinical response at week } 8 \text {; endoscopic response } \\
\text { at week } 8 \text {; and MCS and total histopathology disease severity scores at weeks } 0 \text { and } 8\end{array}$} \\
\hline \multicolumn{3}{|l|}{ Notes } \\
\hline \multicolumn{3}{|l|}{ Risk of bias } \\
\hline Bias & Authors' judgement & Support for judgement \\
\hline $\begin{array}{l}\text { Random sequence generation (selection } \\
\text { bias) }\end{array}$ & Unclear risk & Not described \\
\hline Allocation concealment (selection bias) & Unclear risk & Not described \\
\hline $\begin{array}{l}\text { Blinding of participants and personnel } \\
\text { (performance bias) } \\
\text { All outcomes }\end{array}$ & Low risk & $\begin{array}{l}\text { Patients and investigative staff (except for } \\
\text { the study pharmacist at each site) were } \\
\text { blinded to treatment assignment }\end{array}$ \\
\hline $\begin{array}{l}\text { Blinding of outcome assessment (detection } \\
\text { bias) } \\
\text { All outcomes }\end{array}$ & Unclear risk & Not described \\
\hline $\begin{array}{l}\text { Incomplete outcome data (attrition bias) } \\
\text { All outcomes }\end{array}$ & Low risk & $\begin{array}{l}\text { Drop-out rates were high, but balanced } \\
\text { across groups with similar reasons for with- } \\
\text { drawal }\end{array}$ \\
\hline Selective reporting (reporting bias) & Low risk & All expected outcomes were reported \\
\hline Other bias & Low risk & $\begin{array}{l}\text { The study appears to be free of other } \\
\text { sources of bias }\end{array}$ \\
\hline
\end{tabular}

Placebo response and remission rates in randomised trials of induction and maintenance therapy for ulcerative colitis (Review) 


\begin{tabular}{|c|c|}
\hline Methods & Randomised, double-blind placebo-controlled st \\
\hline Participants & $\begin{array}{l}\text { Patients } 18-70 \text { years with a histologically confirm } \\
\text { least } 3 \text { months prior to study entry } \\
\text { Patients were required to have active UC (MCS } \\
\text { being on stable doses of 5-ASA or SASP for } 3 \\
\text { months, which were to be continued throughout t } \\
\text { day prednisolone or equivalent) for } 2 \text { weeks, whic } \\
\text { discretion }\end{array}$ \\
\hline Interventions & $\begin{array}{l}\text { Single Dose Phase } \\
\text { Group 1: IV PF-00547,659 } 0.03 \mathrm{mg} / \mathrm{kg}(\mathrm{n}=4) \\
\text { Group 2: IV PF-00547,659 } 0.1 \mathrm{mg} / \mathrm{kg}(\mathrm{n}=4) \\
\text { Group 3: IV PF-00547,659 } 0.3 \mathrm{mg} / \mathrm{kg}(\mathrm{n}=4) \\
\text { Group 4: IV PF-00547,659 } 1.0 \mathrm{mg} / \mathrm{kg}(\mathrm{n}=4) \\
\text { Group 5: IV PF-00547,659 } 10 \mathrm{mg} / \mathrm{kg}(\mathrm{n}=4) \\
\text { Group 6: SC PF-00547,659 } 3.0 \mathrm{mg} / \mathrm{kg}(\mathrm{n}=4) \\
\text { Group 7: placebo }(\mathrm{n}=6) \\
\text { Multiple Dose Phase } \\
\text { Group 1: IV PF-00547,659 } 0.1 \mathrm{mg} / \mathrm{kg}(\mathrm{n}=4) \\
\text { Group 2: IV PF-00547,659 } 0.3 \mathrm{mg} / \mathrm{kg}(\mathrm{n}=4) \\
\text { Group 3: IV PF-00547,659 } 3.0 \mathrm{mg} / \mathrm{kg}(\mathrm{n}=4) \\
\text { Group 4: SC PF-00547,659 } 0.3 \mathrm{mg} / \mathrm{kg}(\mathrm{n}=4) \\
\text { Group 5: SC PF-00547,659 } 1.0 \mathrm{mg} / \mathrm{kg}(\mathrm{n}=4) \\
\text { Group 6: placebo }(\mathrm{n}=14)\end{array}$ \\
\hline
\end{tabular}

Outcomes

Primary outcome: safety and tolerability (adverse events, laboratory tests, and immunogenicity)

Secondary outcomes: clinical/endoscopic response or remission rates, and biomarkers

Notes

Risk of bias

\begin{tabular}{l|l|l}
\hline Bias & Authors' judgement & Support for judgement \\
\hline $\begin{array}{l}\text { Random sequence generation (selection } \\
\text { bias) }\end{array}$ & Unclear risk & Not described \\
\hline $\begin{array}{l}\text { Allocation concealment (selection bias) } \\
\text { Low risk }\end{array}$ & $\begin{array}{l}\text { Randomisation was conducted using a se- } \\
\text { quential numbering system based on the } \\
\text { order of patient enrolment }\end{array}$ \\
\hline
\end{tabular}

Blinding of participants and personnel Low risk

Matching placebo (performance bias)

All outcomes

Blinding of outcome assessment (detection Unclear risk bias)

All outcomes

Placebo response and remission rates in randomised trials of induction and maintenance therapy for ulcerative colitis (Review) 
Vermeire 2011 (Continued)

\begin{tabular}{l|l|l}
\hline $\begin{array}{l}\text { Incomplete outcome data (attrition bias) } \\
\text { All outcomes }\end{array}$ & Low risk & $\begin{array}{l}\text { Drop-outs were balanced across groups } \\
\text { with similar reasons for withdrawal }\end{array}$ \\
\hline Selective reporting (reporting bias) & Low risk & All expected outcomes were reported \\
\hline Other bias & Low risk & $\begin{array}{l}\text { The study appears to be free of other } \\
\text { sources of bias }\end{array}$ \\
\hline
\end{tabular}

Vermeire 2014

Methods

Participants
Randomised, double-blind, placebo-controlled, phase II study comparing SC etrolizumab to matched placebo $(\mathrm{N}=124)$

Adult patients (18-75 years) with a diagnosis of UC for $>12$ weeks and a MCS of $>5$ points at screening ( $>6$ points at US sites) and a centrally read MCS score of $>2$, a rectal bleeding subscore $>1$, and disease extension $>25 \mathrm{~cm}$ from the anal verge

Patients failed to respond to prior treatment with immunosuppressants and/or TNF- $\alpha$ antagonists

Interventions

Group 1: etrolizumab $100 \mathrm{mg}(\mathrm{n}=41)$

Patients received $100 \mathrm{mg}$ at weeks 0,4 and 8 , with placebo administered at week 2

Group 2: etrolizumab $300 \mathrm{mg}(\mathrm{n}=40)$

Patients received a $420 \mathrm{mg}$ loading dose at week 0 , followed by $300 \mathrm{mg}$ at weeks 2,4 and 8

Group 3: placebo $(\mathrm{n}=43)$

Risk of bias

Primary outcome: clinical remission at week 10

Secondary outcomes: clinical remission at week 6; achievement of endoscopic subscore of 0 at weeks 6 and 10; achievement of rectal bleeding subscore of 0 at weeks 6 and 10; change from baseline in mucosal healing; histological active disease severity score; pharmacodymamic biomarkers in the peripheral blood and colonic tissue

Notes

124 patients were randomly assigned to placebo $(\mathrm{n}=43)$, etrolizumab $100 \mathrm{mg}(\mathrm{n}=41)$ or etrolizumab $300 \mathrm{mg}(\mathrm{n}=40)$

5 patients had an endoscopic subscore of 0 or 1 , and were excluded from the modified intention-to-treat population (modified intention to treat: 119; 41 patients in the placebo group; 39 patients in the $100 \mathrm{mg}$ group; 39 patients in the $300 \mathrm{mg}$ group)

\begin{tabular}{l|l|l}
\hline Bias & Authors' judgement & Support for judgement \\
\hline $\begin{array}{l}\text { Random sequence generation (selection } \\
\text { bias) }\end{array}$ & Unclear risk & Not described \\
\hline $\begin{array}{l}\text { Allocation concealment (selection bias) } \\
\text { Low risk }\end{array}$ & $\begin{array}{l}\text { Randomisation was conducted with an in- } \\
\text { teractive voice and web response system }\end{array}$ \\
\hline $\begin{array}{l}\text { Placebo response and remission rates in randomised trials of induction and maintenance therapy for ulcerative colitis (Review) } \\
\text { Copyright } \odot \mathbf{2 0 1 7} \text { The Cochrane Collaboration. Published by John Wiley \& Sons, Ltd. }\end{array}$
\end{tabular}


Blinding of participants and personnel Low risk (performance bias)

All outcomes
All patients, assessing physicians, the funder and its agents and study personnel were masked to treatment assignment, except for site pharmacists who prepared drugs but did not interact with patients

Both etrolizumab and placebo appeared as a transparent fluid within the syringes to maintain masking

All patients, assessing physicians, the funder and its agents and study personnel were masked to treatment assignment, except for site pharmacists who prepared drugs but did not interact with patients

Drop-outs were balanced across groups with similar reasons for withdrawal

All outcomes

Low risk

All primary and secondary outcomes were reported

The study appears to be free of other sources of bias

Watanabe 2013

\begin{tabular}{ll} 
Methods & $\begin{array}{l}\text { Phase III multicentre, randomised, double-blind, placebo-con-trolled, parallel-group } \\
\text { study }(\mathrm{N}=129)\end{array}$ \\
\hline Participants & $\begin{array}{l}\text { Patients } 15-74 \text { years old with mild-to-moderate UC and rectal inflammation } \\
\text { Additional inclusion criteria were rectal mucosal score of } 2 \text { or higher in the colonoscopic } \\
\text { observation of the entire colon at the time of registration, UCDAI score of } 4-8, \text { and } \\
\text { disease status of first attack or relapsing/remitting pattern }\end{array}$
\end{tabular}

Interventions

Group 1: mesalazine $1 \mathrm{~g}(\mathrm{n}=65)$

Group 2: placebo suppository $(n=64)$

Outcomes

Primary outcome: endoscopic remission at week 4

Secondary outcomes: clinical remission rate after 4 weeks of treatment (percentage of patients with UCDAI scores of 2 or less and a bleeding score of 0 ), the change in the UCDAI score and the change in each item score and adverse events

Notes

Risk of bias

Bias Authors' judgement

\section{Support for judgement}

Placebo response and remission rates in randomised trials of induction and maintenance therapy for ulcerative colitis (Review) 
Watanabe 2013 (Continued)

\begin{tabular}{|c|c|c|}
\hline $\begin{array}{l}\text { Random sequence generation (selection } \\
\text { bias) }\end{array}$ & Low risk & $\begin{array}{l}\text { Patients were randomly assigned to receive } \\
\text { mesalazine or placebo suppositories at the } \\
\text { start of study drug administration, accord- } \\
\text { ing to a computer-generated randomisa- } \\
\text { tion scheme }\end{array}$ \\
\hline Allocation concealment (selection bias) & Unclear risk & Not described \\
\hline $\begin{array}{l}\text { Blinding of participants and personnel } \\
\text { (performance bias) } \\
\text { All outcomes }\end{array}$ & Unclear risk & Not described \\
\hline $\begin{array}{l}\text { Blinding of outcome assessment (detection } \\
\text { bias) } \\
\text { All outcomes }\end{array}$ & Unclear risk & Not described \\
\hline $\begin{array}{l}\text { Incomplete outcome data (attrition bias) } \\
\text { All outcomes }\end{array}$ & Low risk & $\begin{array}{l}2 \text { patients dropped out of the mesalazine } \\
\text { group; } 10 \text { patients dropped out of the } \\
\text { placebo group }\end{array}$ \\
\hline Selective reporting (reporting bias) & Low risk & All expected outcomes were reported \\
\hline Other bias & Low risk & $\begin{array}{l}\text { The study appears to be free of other } \\
\text { sources of bias }\end{array}$ \\
\hline
\end{tabular}

Williams 1987

Methods

Participants

Interventions

Group 1: 0.5 g 5-ASA suppository $(\mathrm{n}=14)$

Group 2: placebo suppository $(\mathrm{n}=13)$

Patients received treatment three times daily for 6 weeks

Outcomes

Primary outcome: clinical remission

Notes

\section{Risk of bias}

\begin{tabular}{l|ll}
\hline Bias & Authors' judgement & Support for judgement \\
\hline $\begin{array}{l}\text { Random sequence generation (selection } \\
\text { bias) }\end{array}$ & Unclear risk & Not described \\
\hline Allocation concealment (selection bias) & Unclear risk & Not described \\
\hline
\end{tabular}

Placebo response and remission rates in randomised trials of induction and maintenance therapy for ulcerative colitis (Review) 


\begin{tabular}{|c|c|c|}
\hline $\begin{array}{l}\text { Blinding of participants and personnel } \\
\text { (performance bias) } \\
\text { All outcomes }\end{array}$ & Low risk & Identical placebo \\
\hline $\begin{array}{l}\text { Blinding of outcome assessment (detection } \\
\text { bias) } \\
\text { All outcomes }\end{array}$ & Unclear risk & Not described \\
\hline $\begin{array}{l}\text { Incomplete outcome data (attrition bias) } \\
\text { All outcomes }\end{array}$ & Low risk & $\begin{array}{l}\text { There were } 2 \text { drop-outs in the placebo } \\
\text { group }\end{array}$ \\
\hline Selective reporting (reporting bias) & Low risk & All expected outcomes were reported \\
\hline Other bias & Low risk & $\begin{array}{l}\text { The study appears to be free of other } \\
\text { sources of bias }\end{array}$ \\
\hline
\end{tabular}

\section{Yoshimura 2015}

\begin{tabular}{|c|c|}
\hline Methods & Randomised, double-blind, placebo-controlled, phase IIa study $(\mathrm{N}=102)$ \\
\hline Participants & $\begin{array}{l}\text { Patients were 20-65 years of age with a diagnosis of moderately active UC (MCS 6-10, } \\
\text { a rectal bleeding subscore of } 1 \text { or higher, and an endoscopic subscore of } 2 \text { or higher) } \\
\text { Patients had inadequately responded or had an intolerance to 5-ASA and/or corticos- } \\
\text { teroids }\end{array}$ \\
\hline Interventions & $\begin{array}{l}\text { Group 1: } 960 \text { mg AJM } 300(\mathrm{n}=51) \\
\text { Group 2: placebo }(\mathrm{n}=51) \\
\text { Patients received treatment } 3 \text { times daily for } 8 \text { weeks }\end{array}$ \\
\hline Outcomes & $\begin{array}{l}\text { Primary outcome: clinical response (decrease in MCS }>3 \text { points and a decrease of }>30 \% \\
\text { from the baseline score, with a decrease }>1 \text { point on the rectal bleeding subscore or an } \\
\text { absolute rectal bleeding subscore of } 0 \text { or } 1 \text { ) } \\
\text { Secondary outcomes: clinical remission (MCS of }<2 \text { and no subscore }>1 \text { ), mucosal } \\
\text { healing (endoscopic subscore of } 0 \text { or } 1 \text { ), PMCS and adverse events }\end{array}$ \\
\hline Notes & \\
\hline
\end{tabular}

\section{Risk of bias}

\begin{tabular}{|c|c|c|}
\hline Bias & Authors' judgement & Support for judgement \\
\hline
\end{tabular}

Random sequence generation (selection Low risk bias)

Dynamic balancing allocation with mini-

Allocation concealment (selection bias) Low risk mization method

Randomisation performed centrally 
Blinding of participants and personnel Low risk (performance bias)

All outcomes

Blinding of outcome assessment (detection Low risk bias)

All outcomes

Incomplete outcome data (attrition bias) Low risk All outcomes

\begin{tabular}{l|l|l}
\hline Selective reporting (reporting bias) & Low risk & All expected outcomes were reported \\
\hline Other bias & Low risk & $\begin{array}{l}\text { The study appears to be free of other } \\
\text { sources of bias }\end{array}$ \\
\hline
\end{tabular}

Patients, assessing physicians, and the funder were blinded to the assignment of treatment throughout the study

Patients, assessing physicians, and the funder were blinded to the assignment of treatment throughout the study

10 patients discontinued from the placebo group; 4 patients discontinued from the AMJ 300 group
UC: ulcerative colitis

ASA: aminosalicylic acid

SC: subcutaneous

TNF- $\alpha$ : Tumour necrosis factor-alpha

AZA: azathioprine

6-MP: 6-mercaptopurine

CRP: C-reactive protein

DAI: Disease Activity Index

UCDAI: Ulcerative Colitis Disease Activity Index

CAI: Clinical Activity Index

ITT: intention-to-treat

LDP-02: vedolizumab - a humanised a $4 \mathrm{~b} 7$ antibody

MCS: Mayo Clinic Score

MLN02: vedolizumab - a humanised a4b7 antibody

IV: intraveneous

IBDQ: Inflammatory Bowel Disease Questionnaire

UCCS: Ulcerative Colitis Clinical Score

PGA: physician's global assessment

MMX: Multi Matrix System

BMS-936557: anti-IP-10 antibody

IFN- $\beta$ b- $1 \mathrm{a}$ : interferon beta-1a

ACT-1: Active Ulcerative Colitis Trial 1

ACT-2: Active Ulcerative Colitis Trial 2

PMCS: Partial Mayo Clinic Score

MMDAI: Modified Mayo Disease Activity Index

SASP: sulfasalazine

AJM 300: an oral alpha4 integrin antagonist 
Characteristics of excluded studies [ordered by study ID]

\begin{tabular}{|c|c|}
\hline Study & Reason for exclusion \\
\hline Angus 1992 & UCDAI not used \\
\hline Ardizzone 1999 & UCDAI not used \\
\hline Armuzzi 2014 & Not RCT \\
\hline Bayles 1995 & UCDAI not used \\
\hline Biddle 1988 & UCDAI not used \\
\hline Bossa 2013 & UCDAI not used \\
\hline Buckell 1978 & UCDAI not used \\
\hline Burke 1990 & UCDAI not used \\
\hline Calring 1994 & Unclear scoring \\
\hline Campieri 1978 & UCDAI not used \\
\hline Campieri 1981 & UCDAI not used \\
\hline Campieri 1987 & UCDAI not used \\
\hline Campieri 1988 & UCDAI not used \\
\hline Campieri 1989 & UCDAI not used \\
\hline Campieri 1990a & UCDAI not used \\
\hline Campieri 1990b & UCDAI not used \\
\hline Campieri 1991a & UCDAI not used \\
\hline Campieri 1991b & UCDAI not used \\
\hline D’Albasio 1995 & UCDAI not used \\
\hline D’Albasio 1997 & UCDAI not used \\
\hline D’Albasio 1998 & UCDAI not used \\
\hline D’Arienzo 1990 & UCDAI not used \\
\hline D'Haens 2010 & UCDAI not used \\
\hline
\end{tabular}

Placebo response and remission rates in randomised trials of induction and maintenance therapy for ulcerative colitis (Review) 
(Continued)

\begin{tabular}{|c|c|}
\hline Da Silva Sanchez 2014 & Pooled analysis \\
\hline Danielsson 1992 & UCDAI not used \\
\hline Davies 1977 & UCDAI not used \\
\hline Dew 1982 & UCDAI not used \\
\hline Dick 1964 & UCDAI not used \\
\hline Dickinson 1985 & UCDAI not used \\
\hline Dissanayake 1973 & UCDAI not used \\
\hline Feagan 2012 & Pooled analysis \\
\hline Feurle 1989 & UCDAI not used \\
\hline Fruehmorgen 1980 & Not RCT \\
\hline Fruhmorgen 1981 & UCDAI not used \\
\hline Gandolfo 1987 & UCDAI not used \\
\hline Ginsberg 1985 & Hospitalised patients \\
\hline Ginsberg 1988 & UCDAI not used \\
\hline Ginsberg 1992 & UCDAI not used \\
\hline Gionchetti 1999 & Not RCT \\
\hline Hanauer 1989 & UCDAI not used \\
\hline Hanauer 1989a & UCDAI not used \\
\hline Hanauer 1990 & UCDAI not used \\
\hline Hanauer 1992 & UCDAI not used \\
\hline Hanauer 1993 & UCDAI not used \\
\hline Hanauer 1994 & UCDAI not used \\
\hline Hanauer 1996a & UCDAI not used \\
\hline Hanauer 1996b & UCDAI not used \\
\hline Hanauer 1998 & UCDAI not used \\
\hline
\end{tabular}

Placebo response and remission rates in randomised trials of induction and maintenance therapy for ulcerative colitis (Review) 
(Continued)

\begin{tabular}{|c|c|}
\hline Hanauer 1998a & UCDAI not used \\
\hline Hanauer 2007 & Pooled analysis \\
\hline Hanauer 2009 & Pooled analysis \\
\hline Hawkey 1994 & UCDAI not used \\
\hline Hawkey 1997 & UCDAI not used \\
\hline Hawthorne 1992 & UCDAI not used \\
\hline Hetzel 1985 & UCDAI not used \\
\hline Hetzel 1988 & UCDAI not used \\
\hline Hollanders 1982 & UCDAI not used \\
\hline Jewell 1972 & UCDAI not used \\
\hline Jewell 1974 & UCDAI not used \\
\hline Järnerot 2005 & UCDAI not used \\
\hline Kamm 2006 & UCDAI not used \\
\hline Kamm 2008 & No placebo arm \\
\hline Kamm 2009 & Pooled analysis \\
\hline Kamm 2009a & No placebo arm \\
\hline Karner 2014 & UCDAI not used \\
\hline Kirk 1982 & UCDAI not used \\
\hline Kornbluth 1994 & UCDAI not used \\
\hline Korzenik 2003 & UCDAI not used \\
\hline Kumana 1981 & No data reported \\
\hline Lemann 1992 & UCDAI not used \\
\hline Lennard-Jones 1962 & UCDAI not used \\
\hline Lennard-Jones 1965 & UCDAI not used \\
\hline
\end{tabular}


(Continued)

\begin{tabular}{|c|c|}
\hline Lewis 2001 & Hospitalised patients \\
\hline Lewis 2013 & Pooled analysis \\
\hline Lichtenstein $2007 \mathrm{a}$ & Pooled analysis \\
\hline Lichtenstein 2008 & Pooled analysis \\
\hline Lichtenstein 2009a & Pooled analysis \\
\hline Lichtenstein 2009b & Pooled analysis \\
\hline Lichtenstein 2010a & Pooled analysis \\
\hline Lichtenstein 2012 & Pooled analysis \\
\hline Lichtenstein 2013a & Pooled analysis \\
\hline Lichtenstein 2013b & Pooled analysis \\
\hline Lichtiger 1994 & UCDAI not used \\
\hline Lindgren 1997 & Unable to obtain \\
\hline Lindgren 2001 & UCDAI not used \\
\hline Lindgren 2002 & UCDAI not used \\
\hline Lopes 1988 & Unable to obtain \\
\hline Mallow 2013 & Pooled analysis \\
\hline Marakhovski 1999 & Unable to obtain \\
\hline Marteau 1998 & UCDAI not used \\
\hline Mayer 1991 & UCDAI not used \\
\hline Miner 1991 & UCDAI not used \\
\hline Miner 1992 & UCDAI not used \\
\hline Miner 1994 & UCDAI not used \\
\hline Miner 1995 & UCDAI not used \\
\hline Moller 1978 & UCDAI not used \\
\hline
\end{tabular}


(Continued)

\begin{tabular}{|c|c|}
\hline Musch 2002 & UCDAI not used \\
\hline Musch 2002a & UCDAI not used \\
\hline Musch 2005 & UCDAI not used \\
\hline Ngô 1992 & Unable to obtain \\
\hline Nikolaus 2001 & UCDAI not used \\
\hline Onuk 1996 & No placebo arm \\
\hline Orchard 2011 & Pooled analysis \\
\hline Palmer 1981 & UCDAI not used \\
\hline Pastorelli 2008 & No placebo arm \\
\hline Piche 2008 & UCDAI not used \\
\hline Pokrotnieks, 2000 & UCDAI not used \\
\hline Present 2008 & Pooled analysis \\
\hline Pruitt 2008 & Unclear scoring \\
\hline Pullan 1993 & UCDAI not used \\
\hline Reinisch 2011a & UCDAI not used \\
\hline Reinisch 2012 & Pooled analysis \\
\hline Reinisch 2013 & Pooled analysis \\
\hline Reinisch 2014 & Not RCT \\
\hline Reinisch 2014a & Pooled analysis \\
\hline Robinson 1988 & UCDAI not used \\
\hline Rosenberg 1975 & UCDAI not used \\
\hline Rutgeerts 2013d & UCDAI not used \\
\hline Rutgeerts $2013 \mathrm{e}$ & UCDAI not used \\
\hline Sandborn 2009 & UCDAI not used \\
\hline
\end{tabular}


(Continued)

\begin{tabular}{|c|c|}
\hline Sandborn 2010 & Drug not of interest \\
\hline Sandborn 2010a & UCDAI not used \\
\hline Sandborn 2011 & Pooled analysis \\
\hline Sandborn 2011a & UCDAI not used \\
\hline Sandborn 2012 & UCDAI not used \\
\hline Sandborn 2013 & Pooled analysis \\
\hline Sandborn 2013c & Drug not of interest \\
\hline Sands 2001a & UCDAI not used \\
\hline Sands 2001b & UCDAI not used \\
\hline Sands 2014 & Not RCT \\
\hline Schreiber 2006 & Pooled analysis \\
\hline Schreiber 2008a & No placebo arm \\
\hline Schreiber 2008b & Pooled analysis \\
\hline Schulz 1973 & UCDAI not used \\
\hline Selby 1985 & UCDAI not used \\
\hline Solomon 2010 & Pooled analysis \\
\hline Solomon 2011 & Pooled analysis \\
\hline Solomon 2012 & Pooled analysis \\
\hline Tao 2011 & UCDAI not used \\
\hline Tilg 2003 & UCDAI not used \\
\hline Tomecki 1985 & Drug not of interest \\
\hline Touchefeu 2007 & UCDAI not used \\
\hline Travis 2005 & UCDAI not used \\
\hline Travis 2011 & UCDAI not used \\
\hline
\end{tabular}


(Continued)

\begin{tabular}{ll}
\hline Travis 2012 & Pooled analysis \\
\hline Truelove 1955 & UCDAI not used \\
\hline Truelove 1958 & UCDAI not used \\
\hline Truelove 1960 & UCDAI not used \\
\hline Van Hees 1980 & UCDAI not used \\
\hline Watkinson 1958 & UCDAI not used \\
\hline Wright 1993 & UCDAI not used \\
\hline Zakko 2009 & Pooled analysis \\
\hline Zinberg 1990 & UCDAI not used \\
\hline
\end{tabular}

UCDAI: Ulcerative Colitis Disease Activity Index

RCT: randomised controlled trial

Characteristics of studies awaiting assessment [ordered by study ID]

\section{Atreya 2016a}

\begin{tabular}{ll}
\hline Methods & Randomised, double-blind, placebo-controlled trial \\
\hline Participants & 131 patients with active, moderate-to-severe UC \\
\hline Interventions & $\begin{array}{l}\text { DIMS0150 } \\
\text { Placebo }\end{array}$ \\
\hline Outcomes & $\begin{array}{l}\text { Primary: clinical remission } \\
\text { Secondary: mucosal healing, symptomatic remission }\end{array}$ \\
\hline Notes & \\
\hline
\end{tabular}

\section{Harris 2016a}

\begin{tabular}{ll}
\hline Methods & Double-blind, placebo-controlled, first-in-human trial \\
\hline Participants & 37 patients with active UC \\
\hline Interventions & $\begin{array}{l}\text { AVX-470 } \\
\text { Placebo }\end{array}$
\end{tabular}




\section{Harris 2016a (Continued)}

\begin{tabular}{ll}
\hline Outcomes & $\begin{array}{l}\text { Primary: Adverse events } \\
\text { Secondary: pharmacokinetics, immunogenicity } \\
\end{array}$ \\
& Exploratory: clinical and endoscopic response and remission \\
\hline Notes & \\
\hline
\end{tabular}

\section{Kucharzik 2017}

\begin{tabular}{ll}
\hline Methods & Multicenter, randomised, double-blind, phase IIa trial \\
\hline Participants & 120 patients with mildly-to-moderate active UC \\
\hline Interventions & $\begin{array}{l}\text { K(D)PT } \\
\text { Placebo }\end{array}$ \\
\hline Outcomes & $\begin{array}{l}\text { Primary: sustained clinical improvement } \\
\text { Secondary: remission rates and clinical response }\end{array}$ \\
\hline Notes & \\
\hline
\end{tabular}

\section{Naganuma 2016a}

\begin{tabular}{ll}
\hline Methods & Multicentre, randomised, double-blind, placebo-controlled trial \\
\hline Participants & 165 patients with active, mild to moderate distal UC \\
\hline Interventions & $\begin{array}{l}\text { Once-daily budesonide } 2 \mathrm{mg} / 25 \mathrm{ml} \text { foam } \\
\text { Twice-daily budesonide } 2 \mathrm{mg} / 25 \mathrm{ml} \text { foam } \\
\text { Placebo }\end{array}$ \\
\hline Outcomes & Primary: complete mucosal healing, adverse events \\
\hline Notes & \\
\hline
\end{tabular}

\section{Sandborn 2016a}

\begin{tabular}{|c|c|}
\hline Methods & Phase IIb, randomised, placebo-controlled trial \\
\hline Participants & 252 adults with UC \\
\hline Interventions & $\begin{array}{l}\text { Eldelumab } 15 \mathrm{mg} / \mathrm{kg} \\
\text { Eldelumab } 25 \mathrm{mg} / \mathrm{kg} \\
\text { Placebo }\end{array}$ \\
\hline Outcomes & $\begin{array}{l}\text { Primary endpoint was clinical remission (Mayo score } \leq 2 \text {; no individual subscale score }>1 \text { ) at week } 11 \\
\text { Key secondary endpoints included Mayo score clinical response and mucosal healing at week } 11\end{array}$ \\
\hline
\end{tabular}


Sandborn 2016a (Continued)

Notes

Sandborn 2016b

\begin{tabular}{ll}
\hline Methods & Double-blind, placebo-controlled phase II trial \\
\hline Participants & 197 adults with moderate-to-severe UC \\
\hline Interventions & $\begin{array}{l}\text { Ozanimod } 0.5 \mathrm{mg} \\
\text { Ozanimod } 1.0 \mathrm{mg} \\
\text { Placebo }\end{array}$ \\
\hline Outcomes & $\begin{array}{l}\text { Primary: clinical remission } \\
\text { Secondary: clinical response, change in Mayo Clinic Score, mucosal healing }\end{array}$ \\
\hline Notes & \\
\hline
\end{tabular}

\section{Sandborn 2016c}

\begin{tabular}{ll}
\hline Methods & Two identical phase III studies \\
\hline Participants & Patients had moderately to severely active UC \\
\hline Interventions & $\begin{array}{l}\text { Tofacitinib } \\
\text { Placebo }\end{array}$ \\
\hline Outcomes & $\begin{array}{l}\text { Primary: clinical remission } \\
\text { Secondary: mucosal healing }\end{array}$ \\
\hline Notes & \\
\hline
\end{tabular}

\section{Sandborn 2016d}

\begin{tabular}{|c|c|}
\hline Methods & Single or multiple ascending dose trial \\
\hline Participants & 74 patients with UC \\
\hline Interventions & $\begin{array}{l}\text { GS- } 5745(0.3,1.0,2.5 \text { or } 5.0 \mathrm{mg} / \mathrm{kg} ; 3 \text { total IV infusions) } \\
\text { GS- } 5745 \text { ( } 150 \mathrm{mg} ; 5 \text { weekly SC injections) } \\
\text { Placebo }\end{array}$ \\
\hline Outcomes & $\begin{array}{l}\text { The primary outcomes were the safety, tolerability and pharmacokinetics of escalating single and multiple doses of } \\
\text { GS-5745 }\end{array}$ \\
\hline Notes & \\
\hline
\end{tabular}


Van Assche 2016

Methods Exploratory, 2-centre (neoplastic lesions $[\mathrm{NL}]$ and BE), randomised, placebo-controlled, observer-blind phase IIa study

Participants 18 patients aged 22-63 years with moderate-to-severe active UC

Interventions Nanocort

Placebo

Outcomes Primary: adverse events

Secondary: pharmacokinetics, efficacy

Notes

UC: ulcerative colitis

DIMS0150: An experimental drug - a toll-like receptor 9 agonist

AVX-470: An experimental drug - an orally delivered tumour necrosis factor-alpha antagonist

K(D)PT: An experimental drug - a novel tripeptide

GS-5745: An experimental drug - an anti-matrix metalloproteinase-9 monoclonal antibody

IV: intravenous

SC: subcutaneous 


\section{DATA ANDANALYSES}

This review has no analyses.

\section{ADDITIONAL TABLES}

Table 1. Summary of design features in non-IBD trials associated with increased or decreased placebo response rates

\begin{tabular}{|c|c|c|c|}
\hline & Traditional design features & Novel design features & Other quality measures \\
\hline $\begin{array}{l}\text { Increase in placebo } \\
\text { response }\end{array}$ & $\begin{array}{l}\text { Follow up }>12 \text { months } \\
\text { Cross-over design } \\
\text { Increasing number of arms } \\
\text { Comparative effectiveness trials } \\
\text { Higher randomisation ratio of } \\
\text { active drug }\end{array}$ & & $\begin{array}{l}\text { Use of PROs } \\
\text { Improving medication adher- } \\
\text { ence }\end{array}$ \\
\hline $\begin{array}{l}\text { Decrease in } \\
\text { placebo } \\
\text { response }\end{array}$ & Using treatment naive patients & $\begin{array}{l}\text { Induction phases to identify } \\
\text { drug non-responders } \\
\text { Adaptive group allocation } \\
\text { Stepped wedge trial }\end{array}$ & $\begin{array}{l}\text { Using biomarkers instead of } \\
\text { PROs } \\
\text { Enrolling patients with more se- } \\
\text { vere disease } \\
\text { Controlling for centre effects }\end{array}$ \\
\hline
\end{tabular}

Table constructed from information presented in Enck 2013.

PRO: patient reported outcome

Table 2. Several factors associated with placebo response and remission rates in trials of UC

\begin{tabular}{l|l} 
Increase in placebo response and remission rate & $\begin{array}{l}\text { Longer study duration } \\
\text { More follow up visits }\end{array}$ \\
\hline Decrease in placebo response and remission rate & $\begin{array}{l}\text { Defining response as UCDAI } \geq 3 \\
\text { More severe disease activity at enrolment } \\
\text { Mucosal healing as an endpoint }\end{array}$
\end{tabular}

Table constructed from information presented in $\mathrm{Su} 2007$

UCDAI: Ulcerative Colitis Disease Activity Index

Table 3. Baseline characteristics of induction and maintenance trials

\begin{tabular}{|c|c|c|c|c|c|c|c|c|c|}
\hline Trial & Phase & $\begin{array}{l}\text { Setting } \\
\text { (number } \\
\text { of } \\
\text { centres) }\end{array}$ & $\begin{array}{l}\text { Com- } \\
\text { parator }\end{array}$ & $\begin{array}{l}\text { Placebo } \\
\text { patients }\end{array}$ & Mean age & $\begin{array}{l}\text { Follow- } \\
\text { up } \\
\text { (weeks) }\end{array}$ & $\begin{array}{l}\text { Mean en- } \\
\text { try } \\
\text { UCDAI } \\
\text { score }\end{array}$ & $\begin{array}{l}\text { Response } \\
\text { definition }\end{array}$ & $\begin{array}{l}\text { Remis- } \\
\text { sion defi- } \\
\text { nition }\end{array}$ \\
\hline
\end{tabular}


Table 3. Baseline characteristics of induction and maintenance trials (Continued)

\begin{tabular}{|c|c|c|c|c|c|c|c|c|c|c|}
\hline 1 & $\begin{array}{l}\text { Aoyama } \\
2015\end{array}$ & $\begin{array}{l}\text { induction } \\
\text { (1) }\end{array}$ & $\begin{array}{l}\text { Multicen- } \\
\text { ter, single } \\
\text { country } \\
\text { (NS) }\end{array}$ & $\begin{array}{l}\text { Budes- } \\
\text { onide } \\
\text { foam }\end{array}$ & NS & NS & 6 & NS & NS & $\begin{array}{l}\text { RBS } \\
=0 \text {, endo- } \\
\text { scopic sub } \\
\text { score }<1 \\
\text { and stool } \\
\text { frequency } \\
\text { sub score = } \\
0 \text { or de- } \\
\text { crease }>1\end{array}$ \\
\hline 2 & $\begin{array}{l}\text { Beeken } \\
1997\end{array}$ & $\begin{array}{l}\text { induction } \\
\text { (2) }\end{array}$ & $\begin{array}{l}\text { Multicen- } \\
\text { ter, multi- } \\
\text { national } \\
\text { (4) }\end{array}$ & $\begin{array}{l}\text { Aminosal- } \\
\text { icylate }\end{array}$ & 13 & 48 & 6 & 7.8 & $\begin{array}{l}\text { Mean/me- } \\
\text { dian score } \\
\text { improve- } \\
\text { ment }\end{array}$ & NS \\
\hline 3 & $\begin{array}{l}\text { Carbon- } \\
\text { nel } \\
2016\end{array}$ & $\begin{array}{l}\text { induction } \\
\text { (3) }\end{array}$ & $\begin{array}{l}\text { Multicen- } \\
\text { ter, multi- } \\
\text { national } \\
(26)\end{array}$ & $\begin{array}{l}\text { Methotrex- } \\
\text { ate }\end{array}$ & 51 & NS & 24 & NS & NS & $\begin{array}{l}\text { Mayo } \\
\text { Clinic } \\
\text { subscore < } \\
2 \text { with no } \\
\text { item }>1\end{array}$ \\
\hline 4 & $\begin{array}{l}\text { Danese } \\
2014\end{array}$ & $\begin{array}{l}\text { induction } \\
(4)\end{array}$ & $\begin{array}{l}\text { Multicen- } \\
\text { ter, multi- } \\
\text { national } \\
(30)\end{array}$ & $\begin{array}{l}\text { Tralok- } \\
\text { inumab }\end{array}$ & 55 & 41 & 24 & 8.3 & $\begin{array}{l}\text { Decrease } \\
\text { in } \\
\text { Mayo } \geq 3 \\
\text { points and } \\
\geq 30 \% \text {; } \\
\text { plus } \\
\text { decrease } \\
\text { in RBS of } \\
\geq 1 \text { point } \\
\text { or abso- } \\
\text { lute RBS } 0 \\
/ 1\end{array}$ & $\begin{array}{l}\text { Mayo } \\
\text { score } \leq 2 \\
\text { points; no } \\
\text { individual } \\
\text { sub score } \\
>1 \text { point }\end{array}$ \\
\hline 5 & $\begin{array}{l}\text { Deventer } \\
2006\end{array}$ & $\begin{array}{l}\text { induction } \\
(5)\end{array}$ & $\begin{array}{l}\text { Multicen- } \\
\text { ter, multi- } \\
\text { national } \\
(30)\end{array}$ & $\begin{array}{l}\text { Ali- } \\
\text { caforsen }\end{array}$ & 22 & 50 & 6 & 6.5 & $\begin{array}{l}\text { Decrease } \\
\text { in RBS of } \\
0 \text {-1or } \\
\text { more from } \\
\text { baseline }\end{array}$ & NS \\
\hline 6 & $\begin{array}{l}\text { Deventer } \\
2004\end{array}$ & $\begin{array}{l}\text { induction } \\
\text { (6) }\end{array}$ & $\begin{array}{l}\text { Multicen- } \\
\text { ter (NS) }\end{array}$ & $\begin{array}{l}\text { Ali- } \\
\text { caforsen }\end{array}$ & 8 & & 4 & 7.5 & $\begin{array}{l}\text { Percent re- } \\
\text { duction in } \\
\text { DAI }\end{array}$ & NS \\
\hline 7 & $\begin{array}{l}\text { Feagan } \\
2000\end{array}$ & $\begin{array}{l}\text { induction } \\
\text { (7) }\end{array}$ & $\begin{array}{l}\text { Multicen- } \\
\text { ter, single } \\
\text { country } \\
\text { (NS) }\end{array}$ & Vedolizuma & 8 & NS & 4 & 8 & $\begin{array}{l}\text { Improve- } \\
\text { ment in } \\
\text { Baron } \geq 2 \\
\text { points }\end{array}$ & $\begin{array}{l}\text { Mayo } \\
0 \text {; Modi- } \\
\text { fied Baron } \\
0\end{array}$ \\
\hline
\end{tabular}


Table 3. Baseline characteristics of induction and maintenance trials (Continued)

\begin{tabular}{|c|c|c|c|c|c|c|c|c|c|c|}
\hline 8 & $\begin{array}{l}\text { Feagan } \\
2005\end{array}$ & $\begin{array}{l}\text { induction } \\
\text { (8) }\end{array}$ & $\begin{array}{l}\text { Multicen- } \\
\text { ter, single } \\
\text { country } \\
(20)\end{array}$ & Vedolizuma & 63 & 38.9 & 6 & 6.7 & $\begin{array}{l}\text { Improve- } \\
\text { ment } \\
\text { in UCCS } \\
\geq 3 \text { points }\end{array}$ & $\begin{array}{l}\text { UCCS } \leq \\
1 \text { and } \\
\text { a modified } \\
\text { Baron } \leq 1\end{array}$ \\
\hline 9 & $\begin{array}{l}\text { Feagan } \\
2013 a\end{array}$ & $\begin{array}{l}\text { induction } \\
\text { (9) }\end{array}$ & $\begin{array}{l}\text { Multicen- } \\
\text { ter, multi- } \\
\text { national } \\
(26)\end{array}$ & Mesalamine & 141 & 40.4 & 10 & NS & $\begin{array}{l}\text { UCDAI } \\
\text { de- } \\
\text { crease by } \\
\geq 3 \text { points }\end{array}$ & $\begin{array}{l}\text { UC- } \\
\text { DAI, SFS } \\
\text { and RBS } \\
\text { scores of } 0 \text {, } \\
\text { and no fe- } \\
\text { cal } \\
\text { urgency }\end{array}$ \\
\hline \multirow[t]{2}{*}{10} & $\begin{array}{l}\text { Feagan } \\
2013 b\end{array}$ & $\begin{array}{l}\text { induction } \\
(10)\end{array}$ & $\begin{array}{l}\text { Multicen- } \\
\text { ter, multi- } \\
\text { national } \\
(211)\end{array}$ & Vedolizuma & 149 & 41.2 & 6 & 8.6 & $\begin{array}{l}\text { Decrease } \\
\text { in } \\
\text { Mayo } \geq 3 \\
\text { points and } \\
\geq 30 \% \text {; } \\
\text { plus } \\
\text { decrease } \\
\text { in RBS of } \\
\geq 1 \text { point } \\
\text { or abso- } \\
\text { lute RBS } 0 \\
/ 1\end{array}$ & $\begin{array}{l}\text { Mayo } \\
\text { score } \leq 2 \\
\text { points; no } \\
\text { individual } \\
\text { sub score > } \\
1 \text { point }\end{array}$ \\
\hline & & $\begin{array}{l}\text { mainte- } \\
\text { nance (1) }\end{array}$ & $\begin{array}{l}\text { Multicen- } \\
\text { ter, multi- } \\
\text { national } \\
(211)\end{array}$ & Vedolizuma & 126 & 40.3 & 52 & 8.4 & $\begin{array}{l}\text { Decrease } \\
\text { in } \\
\text { Mayo } \geq 3 \\
\text { points and } \\
\geq 30 \% \text {; } \\
\text { plus } \\
\text { decrease } \\
\text { in RBS of } \\
\geq 1 \text { point } \\
\text { or abso- } \\
\text { lute RBS } 0 \\
/ 1\end{array}$ & $\begin{array}{l}\text { Mayo } \\
\text { score } \leq 2 \\
\text { points; no } \\
\text { individual } \\
\text { sub score > } \\
1 \text { point }\end{array}$ \\
\hline 11 & $\begin{array}{l}\text { Hanauer } \\
2000\end{array}$ & $\begin{array}{l}\text { mainte- } \\
\text { nance (2) }\end{array}$ & $\begin{array}{l}\text { Multicen- } \\
\text { ter } \\
(9)\end{array}$ & Mesalamine & 34 & 37.3 & 96 & NS & NS & $\begin{array}{l}\text { UC- } \\
\text { DAI score } \\
=0 \text { was the } \\
\text { definition } \\
\text { of clinical } \\
\text { and endo- } \\
\text { scopic re- } \\
\text { mission } \\
\text { Relapse }\end{array}$ \\
\hline
\end{tabular}

Placebo response and remission rates in randomised trials of induction and maintenance therapy for ulcerative colitis (Review) 
Table 3. Baseline characteristics of induction and maintenance trials (Continued)

\begin{tabular}{|c|c|c|c|c|c|c|c|c|c|c|}
\hline & & & & & & & & & & $\begin{array}{l}\text { defined as } \\
\text { symptoms } \\
\text { of rec- } \\
\text { tal bleed- } \\
\text { ing or } \\
\text { increase in } \\
\text { stool fre- } \\
\text { quency } \\
\text { for }>1 \text { wk } \\
\text { and endo- } \\
\text { scopic evi- } \\
\text { dence } \\
\text { of inflam- } \\
\text { mation }\end{array}$ \\
\hline \multirow[t]{2}{*}{12} & $\begin{array}{l}\text { Jiang } \\
2015\end{array}$ & $\begin{array}{l}\text { induction } \\
\text { (11) }\end{array}$ & $\begin{array}{l}\text { Single } \\
\text { centre }\end{array}$ & Infliximab & 41 & 34.5 & 8 & NS & $\begin{array}{l}\text { Decrease } \\
\text { in } \\
\text { total MCS } \\
>3 \text { points } \\
\text { or }>30 \% \\
\text { from base- } \\
\text { line, with } \\
\text { a decrease } \\
\text { in RBS > } \\
1 \text { point or } \\
\text { an abso- } \\
\text { lute RBS } \\
\text { of } 0 \text { or } 1\end{array}$ & $\begin{array}{l}\text { To- } \\
\text { tal Mayo } \\
\text { score } \\
=2 \text { points } \\
\text { with no } \\
\text { individual } \\
\text { sub score > } \\
1 \text { point }\end{array}$ \\
\hline & & $\begin{array}{l}\text { mainte- } \\
\text { nance (3) }\end{array}$ & $\begin{array}{l}\text { Single } \\
\text { centre }\end{array}$ & Infliximab & 41 & 34.5 & 30 & NS & $\begin{array}{l}\text { Decrease } \\
\text { in } \\
\text { total MCS } \\
>3 \text { points } \\
\text { or }>30 \% \\
\text { from base- } \\
\text { line, with } \\
\text { a decrease } \\
\text { in RBS > } \\
1 \text { point or } \\
\text { an abso- } \\
\text { lute RBS } \\
\text { of } 0 \text { or } 1\end{array}$ & $\begin{array}{l}\text { To- } \\
\text { tal Mayo } \\
\text { score of } \\
<2 \text { points } \\
\text { with no } \\
\text { individual } \\
\text { sub score > } \\
1 \text { point }\end{array}$ \\
\hline 13 & $\begin{array}{l}\text { Kamm } \\
2007\end{array}$ & $\begin{array}{l}\text { induction } \\
\text { (12) }\end{array}$ & $\begin{array}{l}\text { Multicen- } \\
\text { ter. multi- } \\
\text { national } \\
\text { (49) }\end{array}$ & $\begin{array}{l}\text { MMX } \\
\text { mesalamine }\end{array}$ & 86 & 43.2 & 8 & NS & $\begin{array}{l}\text { UCDAI } \\
\text { de- } \\
\text { crease by } \\
\geq 3 \text { points }\end{array}$ & $\begin{array}{l}\text { UC- } \\
\text { DAI } \leq 1+ \\
\text { RBS }= \\
0+\text { SFS }= \\
0 \text {; and } \geq 1 \\
\text { point re- }\end{array}$ \\
\hline
\end{tabular}

Placebo response and remission rates in randomised trials of induction and maintenance therapy for ulcerative colitis (Review) 
Table 3. Baseline characteristics of induction and maintenance trials (Continued)

\begin{tabular}{|c|c|c|c|c|c|c|c|c|c|c|}
\hline & & & & & & & & & & $\begin{array}{l}\text { duction in } \\
\text { sigmoi- } \\
\text { doscopy } \\
\text { score }\end{array}$ \\
\hline 14 & $\begin{array}{l}\text { Leiper } \\
2011\end{array}$ & $\begin{array}{l}\text { induction } \\
\text { (13) }\end{array}$ & $\begin{array}{l}\text { Sin- } \\
\text { gle coun- } \\
\text { try (1) }\end{array}$ & $\begin{array}{l}\text { Ritux- } \\
\text { imab }\end{array}$ & 8 & 50 & 24 & 7.6 & $\begin{array}{l}\text { Decrease } \\
\text { in Mayo } \geq \\
3 \text { points }\end{array}$ & $\begin{array}{l}\text { Decrease } \\
\text { in Mayo } \\
\text { to } \leq 2\end{array}$ \\
\hline 15 & $\begin{array}{l}\text { Lewis } \\
2008\end{array}$ & $\begin{array}{l}\text { induction } \\
\text { (14) }\end{array}$ & $\begin{array}{l}\text { Multicen- } \\
\text { ter, single } \\
\text { country } \\
(15)\end{array}$ & $\begin{array}{l}\text { Rosiglita- } \\
\text { zone }\end{array}$ & 53 & & 12 & NS & $\begin{array}{l}\text { Decrease } \\
\text { in Mayo } \\
\geq 2 \text { points }\end{array}$ & $\begin{array}{l}\text { Mayo } \\
\text { score } \leq 2\end{array}$ \\
\hline 16 & $\begin{array}{l}\text { Lichten- } \\
\text { stein } \\
2007\end{array}$ & $\begin{array}{l}\text { induction } \\
\text { (15) }\end{array}$ & $\begin{array}{l}\text { Multicen- } \\
\text { ter, multi- } \\
\text { national } \\
(52)\end{array}$ & $\begin{array}{l}\text { MMX } \\
\text { mesalamine }\end{array}$ & 93 & 42.6 & 8 & NS & $\begin{array}{l}\text { UCDAI } \\
\text { de- } \\
\text { crease by } \\
\geq 3 \text { points }\end{array}$ & $\begin{array}{l}\text { UC- } \\
\text { DAI } \leq 1+ \\
\text { RBS }= \\
0+\text { SFS= } \\
0 ; \text { and } \geq 1 \\
\text { point re- } \\
\text { duction in } \\
\text { sigmoi- } \\
\text { doscopy } \\
\text { score }\end{array}$ \\
\hline 17 & $\begin{array}{l}\text { Lichten- } \\
\text { stein } \\
2010\end{array}$ & $\begin{array}{l}\text { mainte- } \\
\text { nance (4) }\end{array}$ & $\begin{array}{l}\text { Multicen- } \\
\text { ter, multi- } \\
\text { national } \\
\text { (48) }\end{array}$ & Mesalamine & 96 & 46 & 24 & NS & NS & $\begin{array}{l}\text { Relapse } \\
\text { free at } 6 \\
\text { months }\end{array}$ \\
\hline 18 & $\begin{array}{l}\text { Marteau } \\
2005\end{array}$ & $\begin{array}{l}\text { induction } \\
(16)\end{array}$ & $\begin{array}{l}\text { Multicen- } \\
\text { ter, multi- } \\
\text { national } \\
(43)\end{array}$ & $\begin{array}{l}\text { Mesalazine } \\
\text { enema }\end{array}$ & 56 & NS & 8 & NS & $\begin{array}{l}\text { UCDAI } \\
\text { de- } \\
\text { crease by } \\
\geq 2 \text { points }\end{array}$ & $\begin{array}{l}\text { UCDAI } \\
\leq 1\end{array}$ \\
\hline 19 & $\begin{array}{l}\text { Mayer } \\
2014\end{array}$ & $\begin{array}{l}\text { induction } \\
\text { (17) }\end{array}$ & $\begin{array}{l}\text { Multicen- } \\
\text { ter, multi- } \\
\text { national } \\
(54)\end{array}$ & $\begin{array}{l}\text { BMS- } \\
936557\end{array}$ & 54 & 41.8 & 8 & 7.9 & $\begin{array}{l}\text { Decrease } \\
\text { in } \\
\text { Mayo } \geq 3 \\
\text { points and } \\
\geq 30 \% \text {; } \\
\text { plus } \\
\text { decrease } \\
\text { in RBS of } \\
\geq 1 \text { point } \\
\text { or abso- } \\
\text { lute RBS } 0 \\
/ 1\end{array}$ & $\begin{array}{l}\text { Mayo } \\
\text { score } \leq 2 \\
\text { points; no } \\
\text { individual } \\
\text { sub score } \\
>1 \text { point }\end{array}$ \\
\hline
\end{tabular}


Table 3. Baseline characteristics of induction and maintenance trials (Continued)

\begin{tabular}{|c|c|c|c|c|c|c|c|c|c|c|}
\hline 20 & $\begin{array}{l}\text { Nikolaus } \\
2003\end{array}$ & $\begin{array}{l}\text { induction } \\
\text { (18) }\end{array}$ & $\begin{array}{l}\text { Multicen- } \\
\text { ter, multi- } \\
\text { national } \\
\text { (6) }\end{array}$ & $\begin{array}{l}\text { rIFN- } \beta- \\
\text { 1a }\end{array}$ & 7 & & 6 & NS & $\begin{array}{l}\text { Reduc- } \\
\text { tion of } \geq 3 \\
\text { points in } \\
\text { the UCSS } \\
\text { symp- } \\
\text { toms score } \\
\text { and PGA }\end{array}$ & $\begin{array}{l}\text { All clini- } \\
\text { cal UCSS } \\
\text { sub scores } \\
\text { equal to } 0 \text {, } \\
\text { with a } \\
\text { proctosig- } \\
\text { moi- } \\
\text { doscopy } \\
\text { score of } 0 \\
\text { or } 1\end{array}$ \\
\hline 21 & $\begin{array}{l}\text { Ogata } \\
2006\end{array}$ & $\begin{array}{l}\text { induction } \\
\text { (19) }\end{array}$ & $\begin{array}{l}\text { Multicen- } \\
\text { ter, single } \\
\text { country } \\
(17)\end{array}$ & Tacrolimus & 21 & 30 & 2 & 9.4 & $\begin{array}{l}\text { Reduction } \\
\text { in DAI of } \\
\text { more than } \\
4 \text { points } \\
\text { with } \\
\text { improve- } \\
\text { ment of all } \\
\text { categories }\end{array}$ & $\begin{array}{l}\text { Com- } \\
\text { plete res- } \\
\text { olution of } \\
\text { all symp- } \\
\text { toms } \\
\text { (all assess- } \\
\text { ment } \\
\text { scores } \\
\text { were zero) }\end{array}$ \\
\hline 22 & $\begin{array}{l}\text { Ogata } \\
2012\end{array}$ & $\begin{array}{l}\text { induction } \\
(20)\end{array}$ & $\begin{array}{l}\text { Multicen- } \\
\text { ter, single } \\
\text { country } \\
\text { (NS) }\end{array}$ & Tacrolimus & 30 & NS & 2 & 9.1 & $\begin{array}{l}\text { Reduction } \\
\text { in DAI of } \\
\text { more than } \\
4 \text { points } \\
\text { with } \\
\text { improve- } \\
\text { ment of all } \\
\text { categories }\end{array}$ & $\begin{array}{l}\text { Total DAI } \\
\text { score } 2 \\
\text { with all in- } \\
\text { dividual } \\
\text { sub scores } \\
\text { of } 0 \text { or } 1\end{array}$ \\
\hline \multirow[t]{2}{*}{23} & $\begin{array}{l}\text { Oren } \\
1996\end{array}$ & $\begin{array}{l}\text { induction } \\
\text { (21) }\end{array}$ & $\begin{array}{l}\text { Multicen- } \\
\text { ter, single } \\
\text { country } \\
(12)\end{array}$ & $\begin{array}{l}\text { Methotrex- } \\
\text { ate }\end{array}$ & 37 & 38.9 & 36 & 6.8 & NS & $\begin{array}{l}\text { MCS (in- } \\
\text { clud- } \\
\text { ing the en- } \\
\text { doscopic } \\
\text { sub score) } \\
\text { of }<3 \text { with } \\
\text { no steroid } \\
\text { use, and } \\
\text { without a } \\
\text { score of < } \\
2 \text { without } \\
\text { sigmoi- } \\
\text { doscopy } \\
\text { results }\end{array}$ \\
\hline & & $\begin{array}{l}\text { mainte- } \\
\text { nance (5) }\end{array}$ & $\begin{array}{l}\text { Multicen- } \\
\text { ter, single } \\
\text { country } \\
(12)\end{array}$ & $\begin{array}{l}\text { Methotrex- } \\
\text { ate }\end{array}$ & 37 & 38.9 & 36 & 6.8 & NS & $\begin{array}{l}\text { Relapse } \\
\text { was an } \\
\text { increase in }\end{array}$ \\
\hline
\end{tabular}

Placebo response and remission rates in randomised trials of induction and maintenance therapy for ulcerative colitis (Review) 
Table 3. Baseline characteristics of induction and maintenance trials (Continued)

\begin{tabular}{|c|c|c|c|c|c|c|c|c|c|c|}
\hline & & & & & & & & & & $\begin{array}{l}\text { the MCS } \\
\text { of }>3 \text { (not } \\
\text { including } \\
\text { sigmoi- } \\
\text { doscopy) } \\
\text { and/ } \\
\text { or reintro- } \\
\text { duction of } \\
\text { steroids at } \\
\text { a dose of } \\
>300 \mathrm{mg} / \\
\text { month }\end{array}$ \\
\hline 25 & $\begin{array}{l}\text { Probert } \\
2003\end{array}$ & $\begin{array}{l}\text { induction } \\
\text { (22) }\end{array}$ & $\begin{array}{l}\text { Multicen- } \\
\text { ter, multi- } \\
\text { national } \\
\text { (4) }\end{array}$ & Infliximab & 20 & NS & 6 & 8.5 & $\begin{array}{l}\text { Decrease } \\
\text { in Baron } \\
\text { of } \geq 1\end{array}$ & $\begin{array}{l}\text { UCCS } \\
\leq 2 \text { AND/ } \\
\text { OR Baron } \\
\text { score }=0\end{array}$ \\
\hline 25 & $\begin{array}{l}\text { Reinisch } \\
2011\end{array}$ & $\begin{array}{l}\text { induction } \\
\text { (23) }\end{array}$ & $\begin{array}{l}\text { Multicen- } \\
\text { ter, multi- } \\
\text { national } \\
(94)\end{array}$ & $\begin{array}{l}\text { Adali- } \\
\text { mumab }\end{array}$ & 130 & NS & 8 & 8.7 & $\begin{array}{l}\text { Decrease } \\
\text { in Mayo > } \\
3 \\
\text { points and } \\
\text { decrease } \\
\text { in the RBS } \\
>1 / \text { abso- } \\
\text { lute RBS } \\
\text { of } 0 \text { or } 1\end{array}$ & $\begin{array}{l}\text { Mayo } \\
\text { score < } \\
2 \text { with no } \\
\text { indi- } \\
\text { vidual sub } \\
\text { score }>1\end{array}$ \\
\hline 26 & $\begin{array}{l}\text { Reinisch } \\
2015\end{array}$ & $\begin{array}{l}\text { induction } \\
(24)\end{array}$ & $\begin{array}{l}\text { Multicen- } \\
\text { ter, multi- } \\
\text { national } \\
(38)\end{array}$ & $\begin{array}{l}\text { Anruk- } \\
\text { inzumab }\end{array}$ & 21 & 36.6 & 32 & 6.6 & $\begin{array}{l}\text { Decrease } \\
\text { from base- } \\
\text { line of } \geq 3 \\
\text { points in } \\
\text { to- } \\
\text { tal Mayo } \\
\text { score, with } \\
\text { at least a } \\
30 \% \\
\text { change, } \\
\text { accom- } \\
\text { panied by } \\
\geq 1 \text { point } \\
\text { decrease } \\
\text { or abso- } \\
\text { lute score } \\
\text { of } 0 \text { or } 1 \text { in } \\
\text { RBS }\end{array}$ & $\begin{array}{l}\text { Defined as } \\
\text { propor- } \\
\text { tion } \\
\text { of subjects } \\
\text { with a to- } \\
\text { tal Mayo } \\
\text { score } \leq \\
2 \text {, with no } \\
\text { indi- } \\
\text { vidual sub } \\
\text { score > } 1\end{array}$ \\
\hline 27 & $\begin{array}{l}\text { Rubin } \\
2015\end{array}$ & $\begin{array}{l}\text { induction } \\
(25)\end{array}$ & NS & $\begin{array}{l}\text { Budes- } \\
\text { onide } \\
\text { MMX® }\end{array}$ & NS & NS & & & NS & $\begin{array}{l}\text { rectal } \\
\text { bleeding }\end{array}$ \\
\hline
\end{tabular}

Placebo response and remission rates in randomised trials of induction and maintenance therapy for ulcerative colitis (Review) 
Table 3. Baseline characteristics of induction and maintenance trials (Continued)

\begin{tabular}{|c|c|c|c|c|c|c|c|c|c|c|}
\hline & & & & & & & & & & $\begin{array}{l}\text { and stool } \\
\text { frequency } \\
\text { sub scores } \\
=0\end{array}$ \\
\hline \multirow[t]{2}{*}{28} & $\begin{array}{l}\text { Rutgeerts } \\
2005 a\end{array}$ & $\begin{array}{l}\text { induction } \\
(26)\end{array}$ & $\begin{array}{l}\text { Multicen- } \\
\text { ter, multi- } \\
\text { national } \\
(62)\end{array}$ & Infliximab & 121 & 41.4 & 8 & 8.4 & $\begin{array}{l}\text { Decrease } \\
\text { in } \\
\text { Mayo } \geq 3 \\
\text { points and } \\
\geq 30 \% \text {; } \\
\text { plus } \\
\text { decrease } \\
\text { in RBS of } \\
\geq 1 \text { point } \\
\text { or abso- } \\
\text { lute RBS } 0 \\
/ 1\end{array}$ & $\begin{array}{l}\text { Mayo } \\
\text { score } \leq 2 \\
\text { points; no } \\
\text { individual } \\
\text { sub score } \\
>1 \text { point }\end{array}$ \\
\hline & & $\begin{array}{l}\text { mainte- } \\
\text { nance (6) }\end{array}$ & & & & & & & & \\
\hline 29 & $\begin{array}{l}\text { Rutgeerts } \\
2005 \text { b }\end{array}$ & $\begin{array}{l}\text { induction } \\
(27)\end{array}$ & $\begin{array}{l}\text { Multicen- } \\
\text { ter, multi- } \\
\text { national } \\
(55)\end{array}$ & Infliximab & 123 & 39.3 & 8 & 8.5 & $\begin{array}{l}\text { Decrease } \\
\text { in } \\
\text { Mayo } \geq 3 \\
\text { points and } \\
\geq 30 \% \text {; } \\
\text { plus } \\
\text { decrease } \\
\text { in RBS of } \\
\geq 1 \text { point } \\
\text { or abso- } \\
\text { lute RBS } 0 \\
/ 1\end{array}$ & $\begin{array}{l}\text { Mayo } \\
\text { score } \leq 2 \\
\text { points; no } \\
\text { individual } \\
\text { sub score } \\
>1 \text { point }\end{array}$ \\
\hline
\end{tabular}

mainte-

nance (7)

\begin{tabular}{|c|c|c|c|c|c|c|c|c|c|c|}
\hline 30 & $\begin{array}{l}\text { Rutgeerts } \\
2013 a\end{array}$ & $\begin{array}{l}\text { induction } \\
(28)\end{array}$ & $\begin{array}{l}\text { Multicen- } \\
\text { ter, multi- } \\
\text { national } \\
\text { (15) }\end{array}$ & Etrolizumak & 5 & 30.2 & 4 & 9 & $\begin{array}{l}\text { Decrease } \\
\text { in } \\
\text { Mayo } \geq 3 \\
\text { points and } \\
\geq 30 \% \text {; } \\
\text { plus } \\
\text { decrease } \\
\text { in RBS of } \\
\geq 1 \text { point } \\
\text { or abso- } \\
\text { lute RBS } 0 \\
/ 1\end{array}$ & $\begin{array}{l}\text { Mayo } \\
\text { score } \leq 2 \\
\text { points; no } \\
\text { individual } \\
\text { sub score } \\
>1 \text { point }\end{array}$ \\
\hline
\end{tabular}


Table 3. Baseline characteristics of induction and maintenance trials (Continued)

\begin{tabular}{|c|c|c|c|c|c|c|c|c|c|c|}
\hline 31 & $\begin{array}{l}\text { Rutgeerts } \\
2013 b\end{array}$ & $\begin{array}{l}\text { induction } \\
\text { (29) }\end{array}$ & $\begin{array}{l}\text { Multicen- } \\
\text { ter, multi- } \\
\text { national } \\
\text { (15) }\end{array}$ & Etrolizumat & 5 & 39 & 5 & 10 & $\begin{array}{l}\text { Decrease } \\
\text { in } \\
\text { Mayo } \geq 3 \\
\text { points and } \\
\geq 30 \% \text {; } \\
\text { plus } \\
\text { decrease } \\
\text { in RBS of } \\
\geq 1 \text { point } \\
\text { or abso- } \\
\text { lute RBS } 0 \\
/ 1\end{array}$ & $\begin{array}{l}\text { Mayo } \\
\text { score } \leq 2 \\
\text { points; no } \\
\text { individual } \\
\text { sub score } \\
>1 \text { point }\end{array}$ \\
\hline 32 & $\begin{array}{l}\text { Rutgeerts } \\
2015\end{array}$ & $\begin{array}{l}\text { induction } \\
(30)\end{array}$ & & & & & & & & \\
\hline 33 & $\begin{array}{l}\text { Sandborn } \\
1994\end{array}$ & $\begin{array}{l}\text { induction } \\
\text { (31) }\end{array}$ & $\begin{array}{l}\text { Single } \\
\text { centre }\end{array}$ & $\begin{array}{l}\text { Cy- } \\
\text { closporin }\end{array}$ & 20 & & 4 & NS & $\begin{array}{l}\begin{array}{l}\text { Reduction } \\
\text { of }\end{array} \\
\geq 3 \text { points } \\
\text { in DAI }\end{array}$ & $\begin{array}{l}\text { UCDAI = } \\
0\end{array}$ \\
\hline 34 & $\begin{array}{l}\text { Sandborn } \\
2003\end{array}$ & $\begin{array}{l}\text { induction } \\
(32)\end{array}$ & $\begin{array}{l}\text { Multicen- } \\
\text { ter, single } \\
\text { country } \\
(15)\end{array}$ & $\begin{array}{l}\text { Repifer- } \\
\text { min }\end{array}$ & 28 & NS & 6 & & $\begin{array}{l}\text { Decrease } \\
\text { in Mayo } \\
\geq 3 \text { points } \\
\text { com- } \\
\text { pared with } \\
\text { baseline at } \\
\text { week } 4\end{array}$ & $\begin{array}{l}\text { A score of } \\
\text { zero } \\
\text { on the sig- } \\
\text { moi- } \\
\text { doscopy } \\
\text { all } \\
\text { sub scores } \\
=0 \text { (SFS, } \\
\text { PGA, } \\
\text { RBS) }\end{array}$ \\
\hline 35 & $\begin{array}{l}\text { Sandborn } \\
\text { 2012a }\end{array}$ & $\begin{array}{l}\text { induction } \\
\text { (33) }\end{array}$ & $\begin{array}{l}\text { Multicen- } \\
\text { ter, multi- } \\
\text { national } \\
(103)\end{array}$ & $\begin{array}{l}\text { Adali- } \\
\text { mumab }\end{array}$ & 260 & 41.3 & 8 & 8.9 & $\begin{array}{l}\text { Decrease } \\
\text { in } \\
\text { Mayo } \geq 3 \\
\text { points and } \\
\geq 30 \% \text {; } \\
\text { plus } \\
\text { decrease } \\
\text { in RBS of } \\
\geq 1 \text { point } \\
\text { or abso- } \\
\text { lute RBS } 0 \\
/ 1\end{array}$ & $\begin{array}{l}\text { Mayo } \\
\text { score } \leq 2 \\
\text { points; no } \\
\text { individual } \\
\text { sub score } \\
>1 \text { point }\end{array}$ \\
\hline
\end{tabular}

mainte-

nance $(8)$

Placebo response and remission rates in randomised trials of induction and maintenance therapy for ulcerative colitis (Review) 
Table 3. Baseline characteristics of induction and maintenance trials (Continued)

\begin{tabular}{|c|c|c|c|c|c|c|c|c|c|c|}
\hline 36 & $\begin{array}{l}\text { Sandborn } \\
2012 b\end{array}$ & $\begin{array}{l}\text { induction } \\
(34)\end{array}$ & $\begin{array}{l}\text { Multicen- } \\
\text { ter, multi- } \\
\text { national } \\
(108)\end{array}$ & $\begin{array}{l}\text { Budes- } \\
\text { onide } \\
\text { MMX }\end{array}$ & 128 & & 8 & NS & $\begin{array}{l}\geq 3 \text { - } \\
\text { point de- } \\
\text { crease in } \\
\text { UC- } \\
\text { DAI, and } \\
\geq 1 \text {-point } \\
\text { reduction } \\
\text { in the en- } \\
\text { doscopy } \\
\text { sub score }\end{array}$ & $\begin{array}{l}\text { UCDAI } \\
\leq 1+ \\
\text { RBS }=0 \quad+ \\
S F S=0 ; \\
\text { no mu- } \\
\text { cosal on } \\
\text { colonoscopy } \\
\text {; and } \geq 1 \\
\text { point } \\
\text { reduction } \\
\text { in sigmoi- } \\
\text { doscopy } \\
\text { score }\end{array}$ \\
\hline 37 & $\begin{array}{l}\text { Sandborn } \\
\text { 2012c }\end{array}$ & $\begin{array}{l}\text { induction } \\
\text { (35) }\end{array}$ & $\begin{array}{l}\text { Multicen- } \\
\text { ter, multi- } \\
\text { national } \\
(51)\end{array}$ & $\begin{array}{l}\text { Tofaci- } \\
\text { tinib }\end{array}$ & 48 & 42.5 & 8 & 8.2 & $\begin{array}{l}\text { Decrease } \\
\text { in } \\
\text { Mayo } \geq 3 \\
\text { points and } \\
\geq 30 \% \text {; } \\
\text { plus } \\
\text { decrease } \\
\text { in RBS of } \\
\geq 1 \text { point } \\
\text { or abso- } \\
\text { lute RBS } 0 \\
/ 1\end{array}$ & $\begin{array}{l}\text { MCS = } \\
2 \text { with no } \\
\text { individual } \\
\text { sub scores } \\
1\end{array}$ \\
\hline \multirow[t]{2}{*}{38} & $\begin{array}{l}\text { Sandborn } \\
\text { 2012d }\end{array}$ & $\begin{array}{l}\text { induction } \\
\text { (36) }\end{array}$ & $\begin{array}{l}\text { Multicen- } \\
\text { ter, multi- } \\
\text { national } \\
(142)\end{array}$ & Abatacept & 140 & 40.9 & 12 & 8.8 & $\begin{array}{l}\text { Decrease } \\
\text { in } \\
\text { Mayo } \geq 3 \\
\text { points and } \\
\geq 30 \% \text {; } \\
\text { plus } \\
\text { decrease } \\
\text { in RBS of } \\
\geq 1 \text { point } \\
\text { or abso- } \\
\text { lute RBS } 0 \\
/ 1\end{array}$ & $\begin{array}{l}\text { MCS = } \\
2 \text { with no } \\
\text { individual } \\
\text { sub score> } \\
1\end{array}$ \\
\hline & & $\begin{array}{l}\text { mainte- } \\
\text { nance (9) }\end{array}$ & $\begin{array}{l}\text { Multicen- } \\
\text { ter, multi- } \\
\text { national } \\
(142)\end{array}$ & Abatacept & 66 & NS & 52 & NS & NS & NS \\
\hline 39 & $\begin{array}{l}\text { Sandborn } \\
2013 \mathrm{a} \\
\text { (BUCF300 }\end{array}$ & $\begin{array}{l}\text { induction } \\
\text { (37) }\end{array}$ & $\begin{array}{l}\text { Multicen- } \\
\text { ter, multi- } \\
\text { national } \\
\text { (NS) }\end{array}$ & $\begin{array}{l}\text { Budes- } \\
\text { onide } \\
\text { Foam }\end{array}$ & NS & NS & & 7.9 & NS & $\begin{array}{l}\text { En- } \\
\text { doscopy } \\
\text { score } \leq 1\end{array}$ \\
\hline
\end{tabular}

Placebo response and remission rates in randomised trials of induction and maintenance therapy for ulcerative colitis (Review) 
Table 3. Baseline characteristics of induction and maintenance trials (Continued)

\begin{tabular}{|c|c|c|c|c|c|c|c|c|c|c|}
\hline & & & & & & & & & & $\begin{array}{l}\text { RBS = } \\
0 \text { and im- } \\
\text { prove- } \\
\text { ment or } \\
\text { no change } \\
\text { from } \\
\text { baseline in } \\
\text { stool fre- } \\
\text { quency } \\
\text { subscales } \\
\text { of MM- } \\
\text { DAI** }\end{array}$ \\
\hline 40 & $\begin{array}{l}\text { Sandborn } \\
2013 b \\
\text { (BUCF300: }\end{array}$ & $\begin{array}{l}\text { induction } \\
\text { (38) }\end{array}$ & $\begin{array}{l}\text { Multicen- } \\
\text { ter, multi- } \\
\text { national } \\
\text { (NS) }\end{array}$ & $\begin{array}{l}\text { Budes- } \\
\text { onide } \\
\text { Foam }\end{array}$ & NS & NS & NS & 8 & NS & 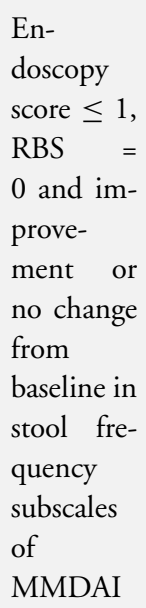 \\
\hline 41 & $\begin{array}{l}\text { Sandborn } \\
2014 a\end{array}$ & $\begin{array}{l}\text { mainte- } \\
\text { nance (10) }\end{array}$ & $\begin{array}{l}\text { Multicen- } \\
\text { ter, multi- } \\
\text { national } \\
(217)\end{array}$ & $\begin{array}{l}\text { Goli- } \\
\text { mumab }\end{array}$ & 331 & 39 & 8 & 8.3 & $\begin{array}{l}\text { Decrease } \\
\text { in } \\
\text { Mayo } \geq 3 \\
\text { points and } \\
\geq 30 \% \text {; } \\
\text { plus } \\
\text { decrease } \\
\text { in RBS of } \\
\geq 1 \text { point } \\
\text { or abso- } \\
\text { lute RBS } 0 \\
/ 1\end{array}$ & $\begin{array}{l}\text { Mayo } \\
\text { score } \leq 2 \\
\text { points; no } \\
\text { individual } \\
\text { subscore } \\
>1 \text { point }\end{array}$ \\
\hline 42 & $\begin{array}{l}\text { Sandborn } \\
2014 b\end{array}$ & $\begin{array}{l}\text { induction } \\
\text { (39) }\end{array}$ & $\begin{array}{l}\text { Multicen- } \\
\text { ter, multi- } \\
\text { national } \\
(251)\end{array}$ & $\begin{array}{l}\text { Goli- } \\
\text { mumab }\end{array}$ & 156 & 40.2 & 54 & 8.3 & $\begin{array}{l}\text { Decrease } \\
\text { in } \\
\text { Mayo } \geq 3 \\
\text { points and } \\
\geq 30 \% \text {; } \\
\text { plus } \\
\text { decrease }\end{array}$ & $\begin{array}{l}\text { Mayo } \\
\text { score } \leq 2 \\
\text { points; no } \\
\text { individual } \\
\text { subscore } \\
>1 \text { point }\end{array}$ \\
\hline
\end{tabular}

Placebo response and remission rates in randomised trials of induction and maintenance therapy for ulcerative colitis (Review) 
Table 3. Baseline characteristics of induction and maintenance trials (Continued)

\begin{tabular}{|c|c|c|c|c|c|c|c|c|c|c|}
\hline & & & & & & & & & $\begin{array}{l}\text { in } \mathrm{RBS} \text { of } \\
\geq 1 \text { point } \\
\text { or abso- } \\
\text { lute RBS } 0 \\
/ 1\end{array}$ & \\
\hline 43 & $\begin{array}{l}\text { Sandborn } \\
2015\end{array}$ & $\begin{array}{l}\text { induction } \\
(40)\end{array}$ & $\begin{array}{l}\text { Multicen- } \\
\text { ter, } \\
\text { multina- } \\
\text { tional } \\
(75)\end{array}$ & $\begin{array}{l}\text { El- } \\
\text { delumab }\end{array}$ & 83 & 42.7 & 11 & 8.6 & $\begin{array}{l}\text { Mayo } \\
\text { score < } 2 \\
\text { points } \\
\text { with no } \\
\text { individual } \\
\text { subscore > } \\
1 \text { point }\end{array}$ & $\begin{array}{l}\text { Reduction } \\
\text { from base- } \\
\text { line } \geq 3 \\
\text { points and } \\
\geq 30 \% \text { in } \\
\text { Mayo } \\
\text { score, re- } \\
\text { duction } \\
\geq \quad 1 \\
\text { in RBS, or } \\
\text { absolute } \\
\text { RBS } \\
\leq 1\end{array}$ \\
\hline 44 & $\begin{array}{l}\text { Sands } \\
2012\end{array}$ & $\begin{array}{l}\text { induction } \\
\text { (41) }\end{array}$ & $\begin{array}{l}\text { Multicen- } \\
\text { ter, multi- } \\
\text { national } \\
(46)\end{array}$ & $\begin{array}{l}\text { Basilix- } \\
\text { imab }\end{array}$ & 51 & 38 & 8 & NS & $\begin{array}{l}\text { Decrease } \\
\text { in } \\
\text { Mayo } \geq 3 \\
\text { points and } \\
\geq 30 \% \text {; } \\
\text { plus } \\
\text { decrease } \\
\text { in RBS of } \\
\geq 1 \text { point } \\
\text { or abso- } \\
\text { lute RBS } 0 \\
/ 1\end{array}$ & $\begin{array}{l}\text { Mayo } \\
\text { score } \leq 2 \\
\text { points; no } \\
\text { individual } \\
\text { subscore } \\
>1 \text { point }\end{array}$ \\
\hline 45 & $\begin{array}{l}\text { Scherl } \\
2009\end{array}$ & $\begin{array}{l}\text { induction } \\
(42)\end{array}$ & $\begin{array}{l}\text { Multicen- } \\
\text { ter, single } \\
\text { country } \\
(55)\end{array}$ & $\begin{array}{l}\text { Bal- } \\
\text { salazide }\end{array}$ & 83 & 45.4 & 8 & 8 & $\begin{array}{l}\geq 3 \text { point } \\
\text { improve- } \\
\text { ment } \\
\text { in modi- } \\
\text { fied Mayo, } \\
\geq 1 \text { point } \\
\text { improve- } \\
\text { ment in } \\
\text { RBS }\end{array}$ & $\begin{array}{l}0 \text { for RBS } \\
\text { and com- } \\
\text { bined } \\
\text { score } \\
\text { of } \leq 2 \text { for } \\
\text { SFS } \\
\text { and PGA } \\
\text { using } \\
\text { the Modi- } \\
\text { fied Mayo } \\
\text { subscales }\end{array}$ \\
\hline 46 & $\begin{array}{l}\text { Schreiber } \\
2007\end{array}$ & $\begin{array}{l}\text { induction } \\
\text { (43) }\end{array}$ & $\begin{array}{l}\text { Multicen- } \\
\text { ter, single } \\
\text { country } \\
(35)\end{array}$ & Tetomilast & 62 & 45.5 & 8 & 7.5 & $\begin{array}{l}\text { Reduction } \\
\text { of } \\
\geq 3 \text { points } \\
\text { in DAI }\end{array}$ & $\begin{array}{l}\text { UCDAI } \\
\leq 1\end{array}$ \\
\hline
\end{tabular}

Placebo response and remission rates in randomised trials of induction and maintenance therapy for ulcerative colitis (Review) 
Table 3. Baseline characteristics of induction and maintenance trials (Continued)

\begin{tabular}{|c|c|c|c|c|c|c|c|c|c|c|}
\hline 47 & $\begin{array}{l}\text { Schroeder } \\
1987\end{array}$ & $\begin{array}{l}\text { induction } \\
(44)\end{array}$ & $\begin{array}{l}\text { Single } \\
\text { center }\end{array}$ & Mesalamine & 38 & 42.7 & 6 & NS & $\begin{array}{l}\text { 'substan- } \\
\text { tial' } \\
\text { improve- } \\
\text { ment in } \\
\text { scores }\end{array}$ & $\begin{array}{l}\text { Com- } \\
\text { plete res- } \\
\text { olution of } \\
\text { symp- } \\
\text { toms (to- } \\
\text { tal score } 0 \text { ) }\end{array}$ \\
\hline 48 & $\begin{array}{l}\text { Sninsky } \\
1991\end{array}$ & $\begin{array}{l}\text { induction } \\
\text { (45) }\end{array}$ & $\begin{array}{l}\text { Multicen- } \\
\text { ter, single } \\
\text { country } \\
\text { (9) }\end{array}$ & Mesalamine & 52 & 39.2 & 6 & NS & $\begin{array}{l}\text { Re- } \\
\text { duction in } \\
\text { the PGA } \\
\text { score and } \\
\text { in at least } \\
\text { one other } \\
\text { compo- } \\
\text { nent score }\end{array}$ & $\begin{array}{l}\text { Com- } \\
\text { plete res- } \\
\text { olution of } \\
\text { all symp- } \\
\text { toms with } \\
\text { all assess- } \\
\text { ment } \\
\text { scores } 0\end{array}$ \\
\hline 49 & $\begin{array}{l}\text { Steinhart } \\
1996\end{array}$ & $\begin{array}{l}\text { induction } \\
\text { (46) }\end{array}$ & $\begin{array}{l}\text { Multicen- } \\
\text { ter, single } \\
\text { country } \\
\text { (2) }\end{array}$ & Butyrate & 19 & 38.6 & 6 & 7.8 & $\begin{array}{l}\text { Reduction } \\
\text { of } \geq 2 \\
\text { points in } \\
\text { UCDAI }\end{array}$ & $\begin{array}{l}\text { UCDAI } \\
\leq 1\end{array}$ \\
\hline 50 & $\begin{array}{l}\text { Suther- } \\
\text { land } \\
1987 a\end{array}$ & $\begin{array}{l}\text { induction } \\
\text { (47) }\end{array}$ & $\begin{array}{l}\text { Multicen- } \\
\text { ter, multi- } \\
\text { national } \\
\text { (8) }\end{array}$ & $\begin{array}{l}\text { Aminosal- } \\
\text { icylate }\end{array}$ & 77 & 36 & 6 & NS & $\begin{array}{l}\text { PGA, } \\
\% \text { drop in } \\
\text { DAI from } \\
\text { baseline } \\
\text { (total and } \\
\text { subscores) }\end{array}$ & NSS \\
\hline 51 & $\begin{array}{l}\text { Suther- } \\
\text { land } \\
1987 b\end{array}$ & $\begin{array}{l}\text { induction } \\
\text { (48) }\end{array}$ & $\begin{array}{l}\text { Multicen- } \\
\text { ter, single } \\
\text { country } \\
\text { (2) }\end{array}$ & $\begin{array}{l}\text { Aminosal- } \\
\text { icylate }\end{array}$ & 30 & 36 & 6 & NS & $\begin{array}{l}\text { PGA, } \\
\text { mean DAI }\end{array}$ & NS \\
\hline 52 & $\begin{array}{l}\text { Suther- } \\
\text { land } \\
1990\end{array}$ & $\begin{array}{l}\text { induction } \\
\text { (49) }\end{array}$ & $\begin{array}{l}\text { Multicen- } \\
\text { ter, multi- } \\
\text { national } \\
\text { (7) }\end{array}$ & $\begin{array}{l}\text { Aminosal- } \\
\text { icylate }\end{array}$ & 44 & 37.8 & 6 & 8.2 & $\begin{array}{l}\text { PGA, } \\
\text { mean DAI }\end{array}$ & NS \\
\hline 53 & $\begin{array}{l}\text { Suzuki } \\
2014\end{array}$ & $\begin{array}{l}\text { mainte- } \\
\text { nance (11) }\end{array}$ & $\begin{array}{l}\text { Multicen- } \\
\text { ter, } \\
\text { sin- } \\
\text { gle coun- } \\
\text { try }(65)\end{array}$ & $\begin{array}{l}\text { Adali- } \\
\text { mumab }\end{array}$ & 96 & 41.3 & 52 & 8.5 & 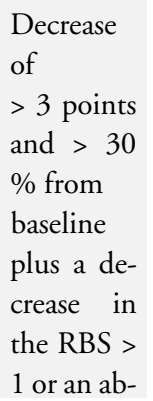 & $\begin{array}{l}\text { Full Mayo } \\
\text { score < } \\
2 \text { with no } \\
\text { individual } \\
\text { subscore > } \\
1\end{array}$ \\
\hline
\end{tabular}

Placebo response and remission rates in randomised trials of induction and maintenance therapy for ulcerative colitis (Review) 
Table 3. Baseline characteristics of induction and maintenance trials (Continued)

\begin{tabular}{|c|c|c|c|c|c|c|c|c|c|c|}
\hline & & & & & & & & & $\begin{array}{l}\text { solute } \\
\text { score of }< \\
1\end{array}$ & \\
\hline \multirow[t]{2}{*}{54} & $\begin{array}{l}\text { Suzuki } \\
2015\end{array}$ & $\begin{array}{l}\text { induction } \\
(51)\end{array}$ & $\begin{array}{l}\text { Multicen- } \\
\text { ter, single } \\
\text { country } \\
\text { (NS) }\end{array}$ & Infliximab & 104 & NS & 8 & NS & NS & NS \\
\hline & & $\begin{array}{l}\text { mainte- } \\
\text { nance (12) }\end{array}$ & $\begin{array}{l}\text { Multicen- } \\
\text { ter, single } \\
\text { country } \\
\text { (NS) }\end{array}$ & Infliximab & 104 & NS & 30 & NS & NS & NS \\
\hline 55 & $\begin{array}{l}\text { Travis } \\
2014\end{array}$ & $\begin{array}{l}\text { induction } \\
\text { (52) }\end{array}$ & $\begin{array}{l}\text { Multicen- } \\
\text { ter, multi- } \\
\text { national } \\
(69)\end{array}$ & $\begin{array}{l}\text { Budes- } \\
\text { onide } \\
\text { MMX }\end{array}$ & 128 & 39.9 & 8 & 6.2 & $\begin{array}{l}\geq 3 \text { - } \\
\text { point de- } \\
\text { crease in } \\
\text { UC- } \\
\text { DAI, and } \\
\geq 1 \text {-point } \\
\text { reduction } \\
\text { in the en- } \\
\text { doscopy } \\
\text { subscore }\end{array}$ & $\begin{array}{l}\text { UCDAI } \\
\leq 1+ \\
\text { RBS }=0 \quad+ \\
S F S=0 ; \\
\text { no mu- } \\
\text { cosal on } \\
\text { colonoscopy } \\
\text { and } \geq 1 \\
\text { point } \\
\text { reduction } \\
\text { in sigmoi- } \\
\text { doscopy } \\
\text { score }\end{array}$ \\
\hline 56 & $\begin{array}{l}\text { Van } \\
\text { Assche } \\
2006\end{array}$ & $\begin{array}{l}\text { induction } \\
\text { (53) }\end{array}$ & $\begin{array}{l}\text { Multicen- } \\
\text { ter, multi- } \\
\text { national } \\
(40)\end{array}$ & $\begin{array}{l}\mathrm{Da}- \\
\text { clizumab }\end{array}$ & 56 & 40.7 & 20 & 8 & $\begin{array}{l}\text { Decrease } \\
\text { in Mayo } \geq \\
3 \text { points }\end{array}$ & $\begin{array}{l}\text { Mayo } \\
0 \text { for en- } \\
\text { doscopy } \\
\text { and RBS; } \\
\text { Mayo 0/ } \\
1 \text { for SFS } \dagger \\
\text { and PGA } \ddagger \\
\end{array}$ \\
\hline 57 & $\begin{array}{l}\text { Vermeire } \\
2011\end{array}$ & $\begin{array}{l}\text { induction } \\
(54)\end{array}$ & $\begin{array}{l}\text { Multicen- } \\
\text { ter, multi- } \\
\text { national } \\
(17)\end{array}$ & $\begin{array}{l}\text { PF- } \\
00547, \\
659\end{array}$ & 20 & 47.9 & 4 & 7.5 & $\begin{array}{l}\text { Decrease } \\
\text { in } \\
\text { Mayo } \geq 3 \\
\text { points and } \\
\geq 30 \% \text {; } \\
\text { plus } \\
\text { decrease } \\
\text { in RBS of } \\
\geq 1 \text { point } \\
\text { or abso- } \\
\text { lute RBS } 0 \\
/ 1\end{array}$ & $\begin{array}{l}\text { Mayo } \\
\text { score } \leq 2 \\
\text { points; no } \\
\text { individual } \\
\text { subscore } \\
>1 \text { point }\end{array}$ \\
\hline
\end{tabular}


Table 3. Baseline characteristics of induction and maintenance trials (Continued)

\begin{tabular}{|c|c|c|c|c|c|c|c|c|c|c|}
\hline 58 & $\begin{array}{l}\text { Vermeire } \\
2014\end{array}$ & $\begin{array}{l}\text { induction } \\
(55)\end{array}$ & $\begin{array}{l}\text { Multicen- } \\
\text { ter. Multi- } \\
\text { national } \\
(40)\end{array}$ & Etrolizumat & 43 & 37.5 & 10 & 9.1 & $\begin{array}{l}\text { Decrease } \\
\text { in } \\
\text { Mayo } \geq 3 \\
\text { points and } \\
\geq 30 \% \text {; } \\
\text { plus } \\
\text { decrease } \\
\text { in RBS of } \\
\geq 1 \text { point } \\
\text { or abso- } \\
\text { lute RBS } 0 \\
/ 1\end{array}$ & $\begin{array}{l}\text { Mayo } \\
\text { score } \leq 2 \\
\text { points; no } \\
\text { individual } \\
\text { subscore } \\
>1 \text { point }\end{array}$ \\
\hline 59 & $\begin{array}{l}\text { Watanabe } \\
2013\end{array}$ & $\begin{array}{l}\text { induction } \\
(56)\end{array}$ & $\begin{array}{l}\text { Multicen- } \\
\text { ter, single } \\
\text { country } \\
(45)\end{array}$ & $\begin{array}{l}\text { Aminosal- } \\
\text { icylate }\end{array}$ & 64 & 41.3 & 4 & 5.5 & NS & $\begin{array}{l}\text { Rectal } \\
\text { mu- } \\
\text { cosal score } \\
\text { of } 0 \text { or } 1\end{array}$ \\
\hline 60 & $\begin{array}{l}\text { Williams } \\
1987\end{array}$ & $\begin{array}{l}\text { induction } \\
(57)\end{array}$ & $\begin{array}{l}\text { Multicen- } \\
\text { ter, single } \\
\text { country } \\
\text { (2) }\end{array}$ & NS & 13 & 42.7 & 6 & 7.4 & NS & $\begin{array}{l}\text { DAI score } \\
\text { of } 0\end{array}$ \\
\hline 61 & $\begin{array}{l}\text { Yoshimura } \\
2015\end{array}$ & $\begin{array}{l}\text { induction } \\
(58)\end{array}$ & $\begin{array}{l}\text { Multicen- } \\
\text { ter, single } \\
\text { country } \\
(42)\end{array}$ & AJM300 & 51 & 42.6 & 8 & 7.7 & $\begin{array}{l}\text { Decrease } \\
\text { in MCS of } \\
\text { at least } 3 \\
\text { points and } \\
\text { a decrease } \\
\text { of at least } \\
30 \% \text { from } \\
\text { the base- } \\
\text { line score, } \\
\text { with a } \\
\text { decrease } \\
\text { of at least } \\
1 \text { point on } \\
\text { the RBS or } \\
\text { an abso- } \\
\text { lute RBS } \\
\text { of } 0 \text { or } 1\end{array}$ & $\begin{array}{l}\text { MCS of } \\
2 \text { or lower } \\
\text { and no } \\
\text { subscore } \\
\text { higher } \\
\text { than } 1\end{array}$ \\
\hline
\end{tabular}

NS: not stated

RBS: rectal bleeding score

DAI: Disease Activity Index

UCCS: Ulcerative Colitis Clinical Score

UCDAI: Ulcerative Colitis Disease Activity Index

SFS: stool frequency score

PGA: physician's global assessment 
Table 4. Stratum-specific placebo rates in induction trials

\begin{tabular}{|c|c|c|c|c|c|c|c|c|}
\hline & \multicolumn{4}{|c|}{ Response } & \multicolumn{4}{|c|}{ Remission } \\
\hline & Trials & $\begin{array}{l}\text { Pooled rate } \\
\% \\
(95 \% \text { CI })\end{array}$ & $\begin{array}{l}\mathbf{I}^{2} \\
\%\end{array}$ & $1^{2} P$ value & Trials & $\begin{array}{l}\text { Pooled rate \% } \\
(95 \% \text { CI })\end{array}$ & $\begin{array}{l}\mathbf{I}^{2} \\
\%\end{array}$ & $\mathbf{I}^{2} \mathbf{P}$ value \\
\hline All trials & 50 & $33(30-36)$ & 73 & $<0.001$ & 47 & $12(9-15)$ & 75 & $<0.001$ \\
\hline \multicolumn{9}{|l|}{ Trial setting } \\
\hline $\begin{array}{l}\text { Multi- } \\
\text { centre, sin- } \\
\text { gle-country }\end{array}$ & 14 & $29(23-35)$ & 64 & 0.003 & 16 & $11(7-17)$ & 75 & $<0.001$ \\
\hline $\begin{array}{l}\text { Multi-cen- } \\
\text { tre, multi- } \\
\text { national }\end{array}$ & 31 & $35(31-40)$ & 78 & $<0.001$ & 27 & $12(10-16)$ & 79 & $<0.001$ \\
\hline $\begin{array}{l}\text { Single- } \\
\text { centre }\end{array}$ & 4 & $26(14-44)$ & 62 & 0.06 & 3 & $6(2-16)$ & 0 & 0.74 \\
\hline \multicolumn{9}{|l|}{ Design } \\
\hline $\begin{array}{l}\text { Stand-alone } \\
\text { induction }\end{array}$ & 38 & $34(29-39)$ & 76 & $<0.001$ & 35 & $11(9-14)$ & 68 & $<0.001$ \\
\hline $\begin{array}{l}\text { Induction } \\
\text { and mainte- } \\
\text { nance }\end{array}$ & 12 & $32(29-35)$ & 28 & 0.04 & 12 & $13(8-20)$ & 87 & $<0.001$ \\
\hline \multicolumn{9}{|l|}{$\begin{array}{l}\text { First author } \\
\text { country }\end{array}$} \\
\hline $\begin{array}{l}\text { North } \\
\text { America }\end{array}$ & 26 & $32(27-36)$ & 73 & $<0.001$ & 23 & $11(9-15)$ & 72 & $<0.001$ \\
\hline Europe & 18 & $37(30-44)$ & 73 & $<0.001$ & 17 & $12(8-18)$ & 74 & $<0.001$ \\
\hline Other & 6 & $29(22-38)$ & 55 & $<0.05$ & 7 & $12(5-25)$ & 86 & $<0.001$ \\
\hline \multicolumn{9}{|l|}{ Drug class } \\
\hline $\begin{array}{l}\text { Corticos- } \\
\text { teroid }\end{array}$ & 2 & $23(19-29)$ & 0 & 1.0 & 2 & $5(2-11)$ & 48 & $<0.17$ \\
\hline $\begin{array}{l}\text { Amicosali- } \\
\text { cylate }\end{array}$ & 11 & $32(20-47)$ & 92 & $<0.001$ & 9 & $18(12-24)$ & 67 & $<0.005$ \\
\hline
\end{tabular}


Table 4. Stratum-specific placebo rates in induction trials (Continued)

\begin{tabular}{|c|c|c|c|c|c|c|c|c|}
\hline $\begin{array}{l}\text { Immuno- } \\
\text { suppressant }\end{array}$ & 3 & $19(7-43)$ & 68 & 0.04 & 5 & $13(3-38)$ & 86 & $<0.001$ \\
\hline Biological & 29 & $35(31-38)$ & 52 & $<0.001$ & 28 & $11(9-14)$ & 61 & $<0.001$ \\
\hline Other & 5 & $34(25-44)$ & 29 & 0.26 & 3 & $7(3-18)$ & 47 & 0.14 \\
\hline \multicolumn{9}{|l|}{$\begin{array}{l}\text { Route } \\
\text { of adminis- } \\
\text { tration }\end{array}$} \\
\hline Topical & 7 & $39(27-53)$ & 73 & $<0.001$ & 5 & $18(9-31)$ & 59 & 0.04 \\
\hline Oral & 17 & $28(22-34)$ & 77 & $<0.001$ & 16 & $10(6-17)$ & 88 & $<0.001$ \\
\hline Intravenous & 17 & $35(30-41)$ & 63 & $<0.001$ & 17 & $13(10-17)$ & 57 & 0.003 \\
\hline $\begin{array}{l}\text { Subcuta- } \\
\text { neous }\end{array}$ & 8 & $35(30-40)$ & 42 & 0.05 & 8 & $8(7-10)$ & 4 & 0.44 \\
\hline
\end{tabular}

\begin{tabular}{l|l|l|l|l|l|l|l|l|}
\hline $\begin{array}{l}\text { Disease } \\
\text { severity on } \\
\text { entry }\end{array}$ & & & & & & & \\
\hline $\begin{array}{l}\text { Mild- } \\
\text { moderate }\end{array}$ & 21 & $32(25-39)$ & 80 & $<0.001$ & 18 & $12(8-17)$ & 77 & $<0.001$ \\
\hline $\begin{array}{l}\text { Moderate- } \\
\text { severe }\end{array}$ & 29 & $34(30-38)$ & 59 & $<0.001$ & 29 & $12(9-15)$ & 75 & $<0.001$ \\
\hline
\end{tabular}

\begin{tabular}{|c|c|c|c|c|c|c|c|c|}
\hline $\begin{array}{l}\text { Disease } \\
\text { duration on } \\
\text { entry }\end{array}$ & & & & & & & & \\
\hline$<5$ years & 5 & $47(37-57)$ & 53 & 0.06 & 9 & $21(17-25)$ & 0.0 & 0.4 \\
\hline$>5$ years & 29 & $33(28-38)$ & 81 & $<0.001$ & 28 & $11(8-15)$ & 82 & $<0.001$ \\
\hline \multicolumn{9}{|l|}{$\begin{array}{l}\text { Inclusion } \\
\text { criteria }\end{array}$} \\
\hline $\begin{array}{l}\text { Minimum } \\
\text { total score > } \\
6\end{array}$ & 21 & $34(30-39)$ & 67 & $<0.001$ & 21 & $12(9-17)$ & 83 & $<0.001$ \\
\hline $\begin{array}{l}\text { Minimum } \\
\text { total score < } \\
6\end{array}$ & 24 & $34(29-40)$ & 69 & $<0.001$ & 21 & $13(9-17)$ & 70 & $<0.001$ \\
\hline
\end{tabular}


Table 4. Stratum-specific placebo rates in induction trials (Continued)

\begin{tabular}{|c|c|c|c|c|c|c|c|c|}
\hline $\begin{array}{l}\text { Endoscopy } \\
\text { sub- } \\
\text { score for in- } \\
\text { clusion }\end{array}$ & & & & & & & & \\
\hline$>2$ & 27 & $34(30-37)$ & 59 & $<0.001$ & 27 & $12(9-15)$ & 71 & $<0.001$ \\
\hline$<2$ & 4 & $46(31-61)$ & 79 & 0.002 & 4 & $25(11-48)$ & 90 & $<0.001$ \\
\hline Not stated & 17 & $29(21-39)$ & 79 & $<0.001$ & 14 & $8(5-13)$ & 49 & 0.015 \\
\hline \multicolumn{9}{|l|}{$\begin{array}{l}\text { Bleeding } \\
\text { score for in- } \\
\text { clusion }\end{array}$} \\
\hline Yes & 9 & $37(29-45)$ & 77 & $<0.001$ & 9 & $16(10-23)$ & 79 & $<0.001$ \\
\hline $\begin{array}{l}\text { No/not } \\
\text { stated }\end{array}$ & 41 & $32(28-36)$ & 70 & $<0.001$ & 38 & $11(8-14)$ & 73 & $<0.001$ \\
\hline \multicolumn{9}{|l|}{$\begin{array}{l}\text { Duration of } \\
\text { follow-up } \\
\text { visits }\end{array}$} \\
\hline$<8$ weeks & 37 & $33(29-34)$ & 81 & $<0.001$ & 32 & $11(9-14)$ & 71 & $<0.001$ \\
\hline$>8$ weeks & 9 & $32(27-37)$ & 42 & $<0.001$ & 11 & $14(8-23)$ & 85 & $<0.001$ \\
\hline \multicolumn{9}{|l|}{$\begin{array}{l}\text { Number } \\
\text { of follow up } \\
\text { visits }\end{array}$} \\
\hline$<3$ & 16 & $32(23-44)$ & 81 & $<0.001$ & 13 & $11(7-19)$ & 63 & 0.001 \\
\hline$>3$ & 24 & $34(30-38)$ & 69 & $<0.001$ & 24 & $12(9-16)$ & 84 & $<0.001$ \\
\hline \multicolumn{9}{|l|}{$\begin{array}{l}\text { Publication } \\
\text { date }\end{array}$} \\
\hline $\begin{array}{l}\text { Before } \\
\text { (and includ- } \\
\text { ing) } 2007\end{array}$ & 23 & $33(26-40)$ & 78 & $<0.001$ & 19 & $13(9-19)$ & 75 & $<0.001$ \\
\hline After 2008 & 27 & $33(29-36)$ & 66 & $<0.001$ & 28 & $11(8-14)$ & 4 & $<0.001$ \\
\hline
\end{tabular}


Table 4. Stratum-specific placebo rates in induction trials (Continued)

\begin{tabular}{|c|c|c|c|c|c|c|c|c|}
\hline$<6$ weeks & 17 & $31(23-41)$ & 86 & $<0.001$ & 19 & $11(8-17)$ & 70 & $<0.001$ \\
\hline$>6$ weeks & 26 & $34(31-38)$ & 61 & $<0.001$ & 26 & $12(9-15)$ & 71 & $<0.001$ \\
\hline \multicolumn{9}{|l|}{$\begin{array}{l}\text { Improve- } \\
\text { ment in en- } \\
\text { doscopy } \\
\text { subscore } \\
\text { required for } \\
\text { definition }\end{array}$} \\
\hline Yes & 21 & $31(27-36)$ & 77 & $<0.001$ & 22 & $10(7-13)$ & 76 & $<0.001$ \\
\hline No & 29 & $35(29-40)$ & 69 & $<0.001$ & 25 & $14(10-19)$ & 71 & $<0.001$ \\
\hline \multicolumn{9}{|l|}{$\begin{array}{l}\text { Improve- } \\
\text { ment } \\
\text { in bleeding } \\
\text { subscore } \\
\text { required for } \\
\text { definition }\end{array}$} \\
\hline Yes & 13 & $31(26-37)$ & 66 & $<0.001$ & 12 & $12(9-17)$ & 65 & 0.001 \\
\hline No & 37 & $34(30-39)$ & 75 & $<0.001$ & 35 & $12(9-15)$ & 77 & $<0.001$ \\
\hline
\end{tabular}

Table 5. Univariable meta-regression analysis of factors contributing to placebo response and remission rates in induction phases

\begin{tabular}{|c|c|c|c|c|}
\hline & Response & & Remission & \\
\hline Study characteristic & Odds ratio $(95 \% \mathrm{CI})$ & p value & Odds ratio $(95 \% \mathrm{CI})$ & p value \\
\hline \multicolumn{5}{|l|}{ Trial setting } \\
\hline $\begin{array}{l}\text { Multi-centre, single- } \\
\text { country }\end{array}$ & 1.0 & 0.16 & 1.0 & 0.59 \\
\hline $\begin{array}{l}\text { Multi-centre, multi-na- } \\
\text { tional }\end{array}$ & $1.39(0.96-2.03)$ & & $1.11(0.64-1.94)$ & \\
\hline Single-centre & $0.95(0.45-1.99)$ & & $0.56(0.14-2.22)$ & \\
\hline
\end{tabular}

Design 
Table 5. Univariable meta-regression analysis of factors contributing to placebo response and remission rates in induction phases (Continued)

\begin{tabular}{|c|c|c|c|c|}
\hline $\begin{array}{l}\text { Stand-alone induction } \\
\text { vs. induction and main- } \\
\text { tenance }\end{array}$ & $0.86(0.61-1.22)$ & 0.40 & $1.21(0.70-2.07)$ & 0.50 \\
\hline \multicolumn{5}{|l|}{ First author country } \\
\hline North America & 1.0 & \multirow[t]{3}{*}{0.24} & 1.0 & \multirow[t]{3}{*}{0.80} \\
\hline Europe & $1.28(0.90-1.81)$ & & $1.15(0.66-2.01)$ & \\
\hline Other & $0.86(0.52-1.42)$ & & $1.24(0.59-2.61)$ & \\
\hline \multicolumn{5}{|l|}{ Drug class } \\
\hline Corticosteroid & 1.0 & \multirow[t]{5}{*}{0.30} & 1.0 & \\
\hline Amicosalicylate & $1.59(0.75-3.36)$ & & $3.95(1.37-11.40)$ & \multirow[t]{4}{*}{0.02} \\
\hline Immunosuppressant & $0.86(0.30-2.44)$ & & $4.95(1.47-16.73)$ & \\
\hline Biological & $1.74(0.86-3.50)$ & & $2.36(0.83-6.40)$ & \\
\hline Other & $1.69(0.71-3.98)$ & & $1.48(0.37-5.88)$ & \\
\hline
\end{tabular}

\section{Route of administra-}

tion

\begin{tabular}{llll}
\hline Topical & 1.0 & 0.12 & $\frac{1.0}{0.0}$ \\
\cline { 1 - 1 } Oral & $0.58(0.35-0.98)$ & & $\frac{0.62(0.25-1.53)}{0.34}$ \\
\cline { 1 - 1 } Intravenous & $0.82(0.49-1.39)$ & & $0.70(0.29-1.70)$ \\
\cline { 1 - 1 } Subcutaneous & $0.82(0.45-1.47)$ & & $0.41(0.15-1.13)$ \\
\hline
\end{tabular}

Disease severity on en-

try

\begin{tabular}{|c|c|c|c|}
\hline Mild-moderate vs. mod- & $1.10(0.80-1.51)$ & 0.57 & $0.94(0.56-1.56)$ \\
\hline
\end{tabular}

erate-severe

\begin{tabular}{l|l|l|l|l}
\hline $\begin{array}{l}\text { Disease duration on } \\
\text { entry }\end{array}$ & & & \\
\hline$<5$ years vs $>5$ years & $0.54(0.32-0.92)$ & 0.02 & $0.57(0.30-1.11)$ & 0.10 \\
\hline
\end{tabular}

\section{Inclusion criteria}


Table 5. Univariable meta-regression analysis of factors contributing to placebo response and remission rates in induction phases (Continued)

\begin{tabular}{|c|c|c|c|c|}
\hline $\begin{array}{l}\text { Minimum total score }>6 \\
\text { vs. minimum total score } \\
<6\end{array}$ & $1.00(0.73-1.35)$ & 0.98 & $1.00(0.59-1.68)$ & 0.99 \\
\hline \multicolumn{5}{|l|}{$\begin{array}{l}\text { Endoscopy subscore } \\
\text { for inclusion }\end{array}$} \\
\hline$>2$ & 1.0 & \multirow[t]{3}{*}{0.02} & 1.0 & \multirow[t]{3}{*}{0.01} \\
\hline$>1$ & $1.70(1.02-2.82)$ & & $2.60(1.25-5.42)$ & \\
\hline Not stated & $0.78(0.56-1.10)$ & & $0.68(0.39-1.20)$ & \\
\hline \multicolumn{5}{|l|}{$\begin{array}{l}\text { Bleeding score for in- } \\
\text { clusion }\end{array}$} \\
\hline Yes vs. no/not stated & $1.70(1.02-2.82)$ & 0.02 & $0.67(0.38-1.20)$ & 0.18 \\
\hline \multicolumn{5}{|l|}{$\begin{array}{l}\text { Duration of follow-up } \\
\text { visits }\end{array}$} \\
\hline$<8$ weeks vs. $>8$ weeks & $0.88(0.57-1.37)$ & 0.59 & $1.41(0.77-2.58)$ & 0.26 \\
\hline \multicolumn{5}{|l|}{$\begin{array}{l}\text { Number of follow-up } \\
\text { visits }\end{array}$} \\
\hline$<3$ weeks vs. $>3$ weeks & $1.05(0.70-1.57)$ & 0.83 & $1.08(0.55-2.12)$ & 0.82 \\
\hline \multicolumn{5}{|l|}{ Publication date } \\
\hline $\begin{array}{l}\text { Before (and including) } \\
2007 \text { vs. after } 2007\end{array}$ & $0.96(0.70-1.33)$ & 0.81 & $0.77(0.47-1.29)$ & 0.32 \\
\hline \multicolumn{5}{|l|}{$\begin{array}{l}\text { Improvement in en- } \\
\text { doscopy subscore re- } \\
\text { quired for definition }\end{array}$} \\
\hline Yes vs. no & $1.16(0.85-1.59)$ & 0.35 & $1.54(0.95-2.48)$ & 0.08 \\
\hline \multicolumn{5}{|l|}{$\begin{array}{l}\text { Improvement in bleed- } \\
\text { ing subscore required } \\
\text { for definition }\end{array}$} \\
\hline Yes vs. no & $1.18(0.83-1.67)$ & 0.36 & $1.0(0.58-1.74)$ & 0.99 \\
\hline
\end{tabular}

Timepoint to measure response response/remission 
Table 5. Univariable meta-regression analysis of factors contributing to placebo response and remission rates in induction phases (Continued)

\begin{tabular}{|c|c|c|c|c|}
\hline$<6$ weeks vs. $>6$ weeks & $1.08(0.76-1.53)$ & 0.68 & $0.97(0.60-1.59)$ & 0.92 \\
\hline \multicolumn{5}{|l|}{$\begin{array}{l}\text { Number of follow-up } \\
\text { visits }\end{array}$} \\
\hline$<3$ visits vs. $>3$ visits & $1.05(0.70-1.57)$ & 0.83 & $1.08(0.55-2.12)$ & 0.82 \\
\hline \multicolumn{5}{|l|}{ Duration of follow-up } \\
\hline$<8$ weeks vs. $>8$ weeks & $0.88(0.57-1.37)$ & 0.59 & $1.41(0.77-2.58)$ & 0.26 \\
\hline \multicolumn{5}{|l|}{ Screening visits } \\
\hline Yes vs. no & $1.12(0.75-0.66)$ & 0.6 & $0.95(0.53-1.72)$ & 0.9 \\
\hline \multicolumn{5}{|l|}{ Number of trial centres } \\
\hline per 1-centre increment & $1.00(1.00-1.03)$ & 0.728 & $1.00(0.99-1.00)$ & 0.304 \\
\hline \multicolumn{5}{|l|}{ Publication year } \\
\hline Per 1 = year increment & $1.01(0.99-1.03)$ & 0.24 & $0.99(0.95-1.03)$ & 0.65 \\
\hline \multicolumn{5}{|l|}{$\begin{array}{l}\text { Extensive disease/pan- } \\
\text { colitis }\end{array}$} \\
\hline$>30 \%$ vs. $<30 \%$ & $1.01(0.69-1.47)$ & 0.969 & $1.23(0.64-2.36)$ & 0.532 \\
\hline \multicolumn{5}{|l|}{ Concurrent steroids } \\
\hline Yes vs. no & $0.88(0.59-1.32)$ & 0.539 & $1.13(0.63-2.05)$ & 0.68 \\
\hline \multicolumn{5}{|l|}{$\begin{array}{l}\text { Concurrent immuno- } \\
\text { suppressive }\end{array}$} \\
\hline Yes vs. no & $0.76(0.53-1.16)$ & 0.727 & $0.18(0.66-2.10)$ & 0.575 \\
\hline \multicolumn{5}{|l|}{ Ratio of active drug } \\
\hline Placebo > 1 vs. $<1$ & $1.01(0.68-1.50)$ & 0.972 & $0.91(0.49-1.67)$ & 0.757 \\
\hline \multicolumn{5}{|l|}{$\begin{array}{l}\text { Primary time point to } \\
\text { measure endpoint }\end{array}$} \\
\hline per 1-week increment & $1.00(0.93-1.07)$ & 0.97 & $1.06(1.02-1.10)$ & 0.01 \\
\hline
\end{tabular}




\section{A P P E N D I CES}

\section{Appendix I. Search Strategies for MEDLINE, EMBASE and CENTRAL databases}

\section{MEDLINE (1950 - current)}

1. random\$.tw.

2. factorial\$.tw.

3. (crossover\$ or cross over\$ or cross-over\$).tw.

4. placebo\$.tw.

5. single blind.mp.

6. double blind.mp.

7. triple blind.mp.

8. (singl\$ adj blind $\$)$.tw.

9. (double\$ adj blind\$).tw.

10. (tripl\$ adj blind $\$$ ).tw.

11. assign $\$$.tw.

12. allocat\$.tw.

13. crossover procedure/

14. double blind procedure/

15. single blind procedure/

16. triple blind procedure/

17. randomized controlled trial/

18. or/1-17

19. ulcerative colitis.mp. or exp Colitis, Ulcerative/

20. (proctocolitis or proctosigmoiditis or rectocolitis or rectosigmoiditis or proctitis or "distal colitis").mp.

21. 19 or 20

22. 18 and 21

EMBASE (1980 - Current)

1. random\$.tw.

2. factorial\$.tw.

3. (crossover\$ or cross over\$ or cross-over\$).tw.

4. placebo\$.tw.

5. single blind.mp.

6. double blind.mp.

7. triple blind.mp.

8. (singl\$ adj blind\$).tw.

9. (double\$ adj blind\$).tw.

10. (tripl\$ adj blind\$).tw.

11. assign \$.tw.

12. allocat $\$ . t w$.

13. crossover procedure/

14. double blind procedure/

15. single blind procedure/

16. triple blind procedure/

17. randomized controlled trial/

18. or/1-17

19. ulcerative colitis.mp. or exp Colitis, Ulcerative/

20. (proctocolitis or proctosigmoiditis or rectocolitis or rectosigmoiditis or proctitis or "distal colitis").mp.

21. 19 or 20

22. 18 and 21

Cochrane Library (CENTRAL)

"Ulcerative colitis" or "proctocolitis" or "proctosigmoiditis" or "rectocolitis" or "rectosigmoiditis" or "proctitis" or "distal colitis" 


\section{CONTRIBUTIONSOFAUTHORS}

Study design: Vipul Jairath, GY Zou, Clear E Parker, John K MacDonald, Simon Travis, Geert D’Haens, William J Sandborn

Data screening: Vipul Jairath, Claire E Parker

Data extraction: Vipul Jairath, Claire E Parker, Turki AlAmeel, Mohammad Al Beshir, Majid A Almadi, Talal Al-Taweel, Nathan SS Atkinson, Sujata Biswas, Thomas Chapman, Parambir S Dulai, Mark A Glaire, Daniël R Hoekman, Andreas Koutsoumpas, Elizabeth Minas, Mahmoud H Mosli, Mark Samaan

Statistical analysis: Vipul Jairath, GY Zou

Manuscript preparation: Vipul Jairath, Claire E Parker

Revision for intellectual content: Vipul Jairath, Claire E Parker, Turki AlAmeel, Mohammad Al Beshir, Majid A Almadi, Talal AlTaweel, Nathan SS Atkinson, Sujata Biswas, Thomas Chapman, Parambir S Dulai, Mark A Glaire, Daniël R Hoekman, Andreas Koutsoumpas, Elizabeth Minas, Mahmoud H Mosli, Mark Samaan, John K MacDonald, Simon Travis, Geert D’Haens, William J Sandborn

\section{DECLARATIONSOF INTEREST}

Vipul Jairath has received consulting fees from Sandoz, Takeda, Abbvie, Janssen; and speakers fees from Takeda, Abbvie, Ferring, Janssen All of these financial activities are outside of the submitted work.

GY Zou: None known

Claire E Parker: None known

John K MacDonald: None known

Turki AlAmeel: None known

Mohammad Al Beshir: None known

Majid A Almadi: None known

Talal Al-Taweel has received consulting fees from AbbVie and Takeda; and lecture fees from Abbvie and Janssen and travel/accommodations/meeting expenses from Abbvie, Janssen, Novartis, Newbridge and Takeda. All of these financial activities are outside the submitted work.

Nathan Atkinson has received funds from AbbVie for travel/accommodations/meeting expenses. All of these financial activities are outside the submitted work.

Sujata Biswas: None known

Thomas Chapman has received support for a DPhil in Biomedical and Clinical Sciences from the Wellcome Trust and Oxford BRC. The topic of study relates to the immunology of Crohn's disease. Dr Chapman has no other known declarations of interest.

Parambir Dulai has received consulting fees from Takeda, research support (grants/grants pending) from Takeda and Pfizer; and payment for lectures from Takeda. All of these financial activities are outside of the submitted work.

Mark A Glaire: None known

Daniël R Hoekman: None known

Andreas Koutsoumpas: None known

Elizabeth MInas: None known

Mahmoud H Mosli: None known

Mark Samaan: None known

Reena Khanna has received honoraria from AbbVie, Jansen, Pfizer, Shire, and Takeda for consultancy. All of these financial activities are outside of the submitted work.

Placebo response and remission rates in randomised trials of induction and maintenance therapy for ulcerative colitis (Review) 
Simon Travis declined commercial consultancy or speaking engagements to avoid any perception of a conflict of interest as President of ECCO 2012-2014. Since then he has received fees for consulting from AbbVie, Astra Zeneca, Celgene, Falk, Ferring, GSK, Janssen, Merck (to the Institution), Novartis, Novo Nordisk (both self and Institution), NPS Pharmaceuticals, Pfizer, Proximagen, Takeda, Topivert, Vertex (to the Institution), Warner-Chilcott Amgen, Biogen, Boehringer Ingelheim, Bristol-Myers Squibb, Cosmo, Lilly, Neovacs, Shire, Sigmoid Pharma, UCB, VHsquared and Vifor; lecture fee(s) from AbbVie, Ferring, Takeda, Amgen, Biogen, fee(s) for expert testimony to the FDA and EMA from Cosmo Technologies and Santarus; royalties from Wiley Blackwel, Elsevier and Oxford University Press for books; and funding from Schering Plough, Procter \& Gamble, Merck and AbbVie for part salary for a nurse involved in therapeutic education. All of these financial activities are outside of the submitted work.

Geert D'Haens has received consulting fees from Abbvie, Ablynx, Actogenix, Amgen, AM Pharma, AstraZeneca, Boerhinger Ingelheim, Cosmo, Ferring, DrFALK Pharma, Celgene, Celltrion, Centocor/Jansen Biologics, Engene, Galapagos, Giuliani, GSK, Hospira, Millenium/Takeda, Mitsubishi Pharma, MSD, Mundipharma, Novonordisk, Pfizer, Prometheus Laboratories, Receptos, Salix, Sandoz, SetpointShire, TEVA, Tigenix, Tillotts, and Versant; he has received grants/has grants pending from Abbvie, MSD, Takeda, GSK, GivenImaging and Photopill; he has received payment for lectures from Abbvie, Ferring, Centocor/Jansen Biologics, Millenium/ Takeda, MSD, Shire, and Tillotts; he has stock options with Engene. All of these financial activities are outside the submitted work.

William Sandborn has received consultancy fees from Abbott Laboratories, ActoGeniX NV, AGI Therapeutics, Inc., Alba Therapeutics Corporation, Albireo, Alfa Wasserman, Amgen, AM-Pharma BV, Anaphore, Astellas Pharma, Athersys, Inc., Atlantic Healthcare Limited, Axcan Pharma (now Aptalis), BioBalance Corporation, Boehringer-Ingelheim Inc, Bristol Meyers Squibb: (both money paid to WS and institution), Celegene, Celek Pharmaceuticals, Cellerix SL, Cerimon Pharmaceuticals, ChemoCentryx, CoMentis, Cosmo Technologies, Coronado Biosciences, Cytokine Pharmasciences, Eagle Pharmaceuticals, Eisai Medical Research Inc., Elan Pharmaceuticals: (both money paid to WS and institution), EnGene, Inc., Eli Lilly, Enteromedics: (both money paid to WS and institution), Exagen Diagnostics, Inc., Ferring Pharmaceuticals, Flexion Therapeutics, Inc., Funxional Therapeutics Limited, Genzyme Corporation, Genentech (now Roche): (both money paid to WS and institution), Gilead Sciences, Given Imaging, Glaxo Smith Kline, Human Genome Sciences, Ironwood Pharmaceuticals (previously Microbia Inc.), Janssen (previously Centocor): (both money paid to WS and institution), KaloBios Pharmaceuticals, Inc., Lexicon Pharmaceuticals, Lycera Corporation, Meda Pharmaceuticals (previously Alaven Pharmaceuticals), Merck Research Laboratories, MerckSerono, Millennium Pharmaceuticals (subsequently merged with Takeda): (both money paid to WS and institution), Nisshin Kyorin Pharmaceuticals Co., Ltd., Novo Nordisk A/S, NPS Pharmaceuticals, Optimer Pharmaceuticals, Orexigen Therapeutics, Inc., PDL Biopharma: (money paid to institution), Pfizer: (both money paid to WS and institution), Procter and Gamble: (both money paid to WS and institution), Prometheus Laboratories, ProtAb Limited, Purgenesis Technologies, Inc., Relypsa, Inc., Salient Pharmaceuticals, Salix Pharmaceuticals, Inc., Santarus, Schering Plough Corporation (acquired by Merck), Shire Pharmaceuticals: (money paid to institution), Sigmoid Pharma Limited, Sirtris Pharmaceuticals, Inc. (a GSK company), S.L.A. Pharma (UK) Limited, Takeda: (both money paid to WS and institution), Targacept, Teva Pharmaceuticals, Therakos, Tillotts Pharma AG (acquired by Zeria Pharmaceutical Co., Ltd), TxCell SA, UCB Pharma: (both money paid to WS and institution), Viamet Pharmaceuticals, Vascular Biogenics Limited (VBL), Warner Chilcott UK Limited, Wyeth (now Pfizer); fees for expert testimony: Dickinson, Prud'Homme, Adams \& Ingram; Grants/Grants Pending: Abbott Laboratories, Bristol Meyers Squibb, Genentech, Glaxo Smith Kline, Janssen (previously Centocor), Millennium Pharmaceuticals (now Takeda), Novartis, Pfizer, Procter and Gamble Pharmaceuticals, Shire Pharmaceuticals, UCB Pharma; payment for lectures: Abbott Laboratories, Bristol Meyers Squibb, Janssen (previously Centocor); patents: Sandborn WJ. Use of topical azathioprine to treat inflammatory bowel disorders. United States patent number: 5,691,343. Date of patent: November 25, 1997; Sandborn WJ, Rhodes J. Colonic delivery of nicotine to treat inflammatory bowel disease. South African patent number: 97/1020. Date of patent: January 28, 1998; Sandborn WJ. Use of azathioprine to treat Crohn's disease. United States patent number: 5,733,915. Date of patent: March 31, 1998; Sandborn WJ, Rhodes J. Colonic delivery of nicotine to treat inflammatory bowel disease. United States patent number: 5,846,983. Date of patent: December 8, 1998; Sandborn WJ. Azathioprine compositions for colonic administration. New Zealand patent number: 306062. Date of Patent: February 11, 1999; Sandborn WJ. Azathioprine compositions for colonic administration. Singapore patent number: 45647. Date of Patent: March 14, 1999; Sandborn WJ, Rhodes J, Rhodes P, Evans BK. Colonic delivery of nicotine to treat inflammatory bowel disease. United States patent number: 5,889,028. Date of patent: March 30, 1999; Sandborn WJ. Topical formulations of azathioprine to treat inflammatory bowel disorders. United States patent number: 5,905,081. Date of Patent: May 18, 1999; Sandborn WJ. Azathioprine compositions for colonic administration. Australia patent number: 707168. Date of Patent: October 14, 1999; Sandborn WJ, Rhodes J, Evans BK. Intestinal absorption of nicotine to treat nicotine responsive conditions. Australia patent number: 718052. Date of patent: July 20, 2000; Sandborn WJ, Rhodes J. Colonic delivery of nicotine to treat inflammatory bowel disease. United States patent number: 6,166,044. Date of patent: December 26, 2000; Sandborn WJ. Use of topical azathioprine and thioguanine to treat colorectal adenomas. United States patent number: 6,166,024. Date of patent: December 26, 2000; Rhodes J, Evans BK, Rhodes P, Sandborn WJ. Intestinal absorption of nicotine to treat nicotine responsive conditions. United States patent number: 6,238,689. Date of patent: May 29, 2001;

Placebo response and remission rates in randomised trials of induction and maintenance therapy for ulcerative colitis (Review) 
Sandborn, WJ. Azathioprine compositions for colonic administration. Czech Republic patent number: 290428. Date of patent: May 27, 2002; Sandborn, WJ, Rhodes J. Colonic delivery of nicotine to treat IBD. Mexico patent number: 209636. Date of Patent August 12, 2002; Sandborn WJ. Enema and enterically-coated oral dosage forms of azathioprine. United States Patent No.: 6,432,967. Date of patent: August 13, 2002; Sandborn WJ, Rhodes J. Colonic delivery of nicotine to treat nicotine responsive conditions. Europe patent number: 0954337. Date of patent: November 2, 2002; Sandborn WJ, Rhodes J, Rhodes P, Evans BK. Colonic delivery of nicotine to treat IBD. Europe patent number: 893998. Date of patent: April 15, 2003; Sandborn WJ, Rhodes J, Rhodes P, Evans BK. Colonic delivery of nicotine to treat inflammatory bowel disease. Hong Kong patent number: HK1019043. Date of patent: August 1, 2003; Sandborn WJ, Rhodes J, Rhodes P, Evans BK. Colonic delivery of nicotine to treat IBD. China patent number: ZL97192177. Date of patent: November 12, 2003; Sandborn W, Rhodes J, Rhodes P, Evans B. Colonic delivery of nicotine to treat inflammatory bowel disease. Czech patent number: 293616. Patent date: 2004; Rhodes J, Sandborn WJ, Rhodes P, Evans BK. Colonic deliver of nicotine to treat inflammatory bowel disease. Canada patent number: 2,246,235. Patent date: 2007; Sachetto JP, Sandborn WJ, Tremaine WJ. Pharmaceutical composition for the treatment of inflammatory bowel disease. United States patent number: 7341741. Patent date 2008; Rhodes J, Evans BK, Rhodes P, Sandborn WJ. Intestinal absorption of nicotine to treat nicotine responsive conditions. Canadian patent number: 2,260,909. Patent date 2008; Levy MJ, Camilleri ML, Murray JA, Sandborn WJ. Obesity treatment and device. United States patent number: 7,803,195 B2. Date of patent September 28, 2010; Dr Sandborn has stock options with Enteromedics. All of these financial activities are outside of the submitted work.

Brian Feagan has received fee(s) from Abbott/AbbVie, Amgen, Astra Zeneca, Avaxia Biologics Inc., Bristol-Myers Squibb, Celgene, Centocor Inc., Elan/Biogen, Ferring, JnJ/Janssen, Merck, Novartis, Novonordisk, Pfizer, Prometheus Laboratories, Protagonist, Salix Pharma, Takeda, Teva, Tillotts Pharma AG, UCB Pharma for Board membership; fee(s) from Abbott/AbbVie, Actogenix, Albireo Pharma, Amgen, Astra Zeneca, Avaxia Biologics Inc., Axcan, Baxter Healthcare Corp., Boehringer-Ingelheim, Bristol-Myers Squibb, Calypso Biotech, Celgene, Elan/Biogen, EnGene, Ferring Pharma, Roche/Genentech, GiCare Pharma, Gilead, Given Imaging Inc., GSK, Ironwood Pharma, Janssen Biotech (Centocor), JnJ/Janssen, Kyowa Kakko Kirin Co Ltd., Lexicon, Lilly, Merck, Millennium, Nektar, Novonordisk, Pfizer, Prometheus Therapeutics and Diagnostics, Protagonist, Receptos, Salix Pharma, Serono, Shire, Sigmoid Pharma, Synergy Pharma Inc., Takeda, Teva Pharma, Tillotts, UCB Pharma, Vertex Pharma, Warner-Chilcott, Wyeth, Zealand, and Zyngenia for consultancy; and lecture fee(s) from: Abbott/AbbVie, JnJ/Janssen, Takeda, Warner-Chilcott, and UCB Pharma. All of these activities are outside the submitted work.

\section{INDEX TERMS}

\section{Medical Subject Headings (MeSH)}

*Induction Chemotherapy [statistics \& numerical data]; *Maintenance Chemotherapy [statistics \& numerical data]; Aminosalicylic Acids [ ${ }^{*}$ therapeutic use]; Anti-Inflammatory Agents, Non-Steroidal [*therapeutic use]; Biological Products [ ${ }^{*}$ therapeutic use]; Colitis, Ulcerative [*drug therapy]; Gastrointestinal Hemorrhage [complications; diagnosis]; Placebo Effect; Randomized Controlled Trials as Topic; Rectum

\section{MeSH check words}

Adult; Humans

Placebo response and remission rates in randomised trials of induction and maintenance therapy for ulcerative colitis (Review) 